

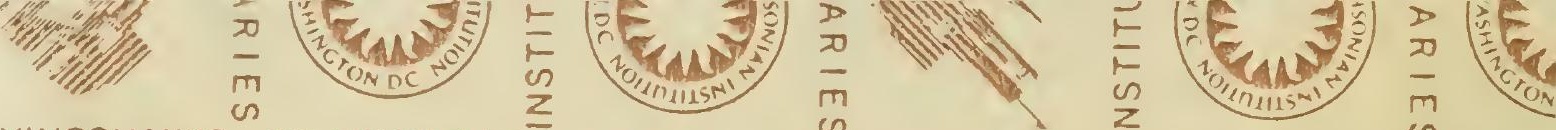
NYINOSHIIWS SBIYYY817 LIBRARIES SMITHSONIAN INSTITUTION NOIL

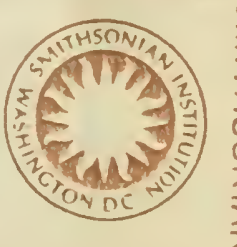

SMITHSONIAN
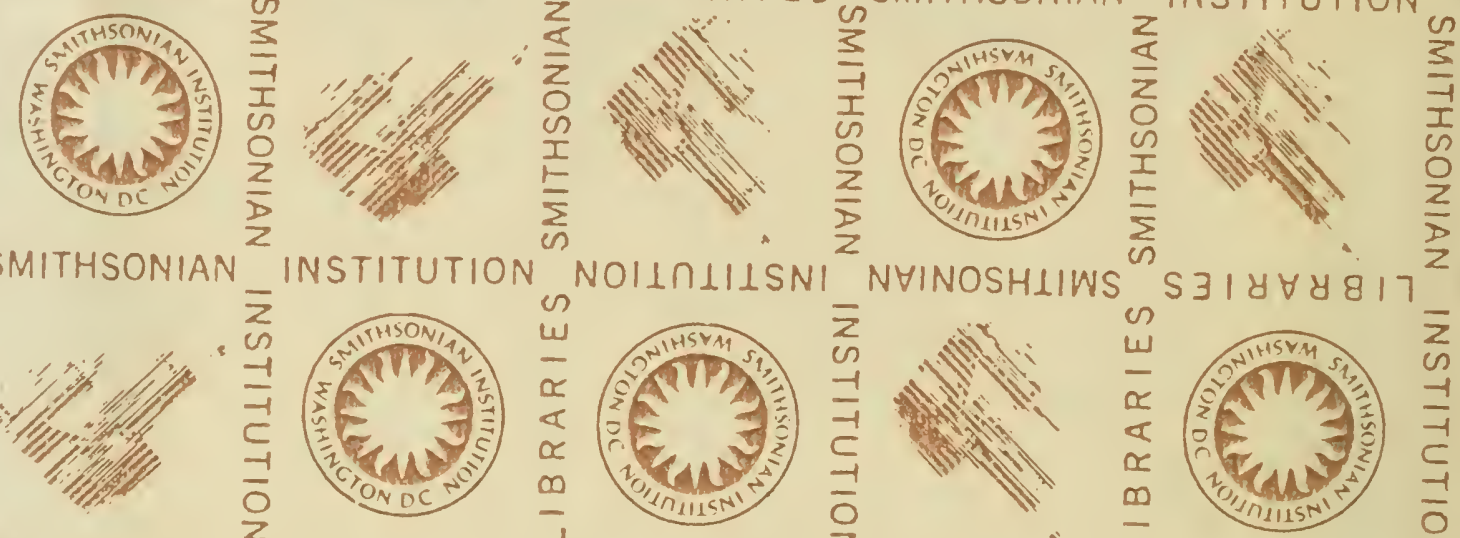

SMITHSONIAN

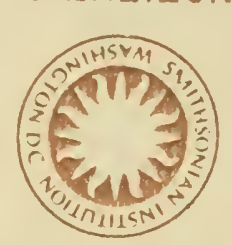

$\bar{z}$
on
$\overline{1}$
$\bar{c}$
$\frac{1}{0}$
$\frac{2}{z}$
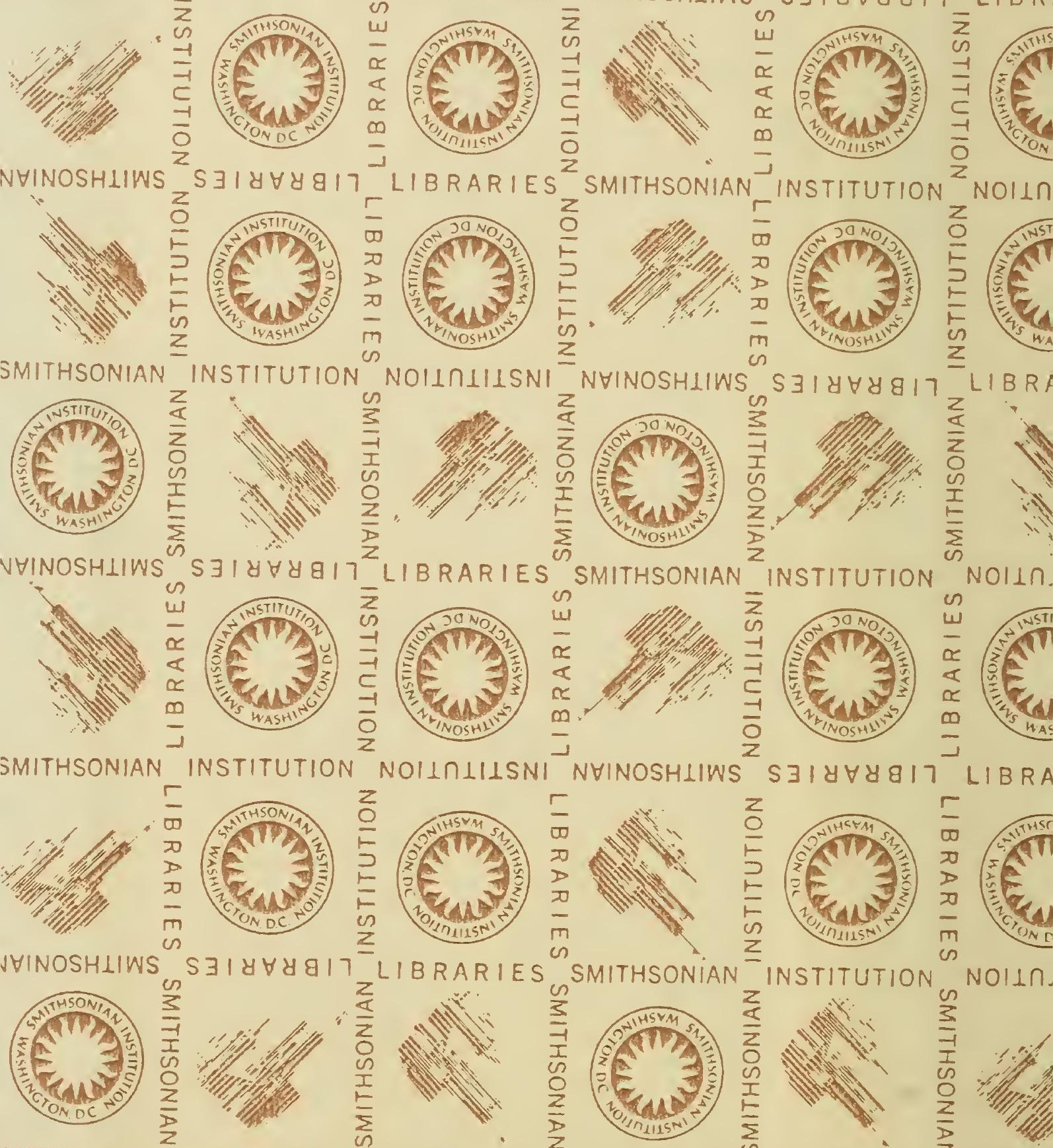

NOIL
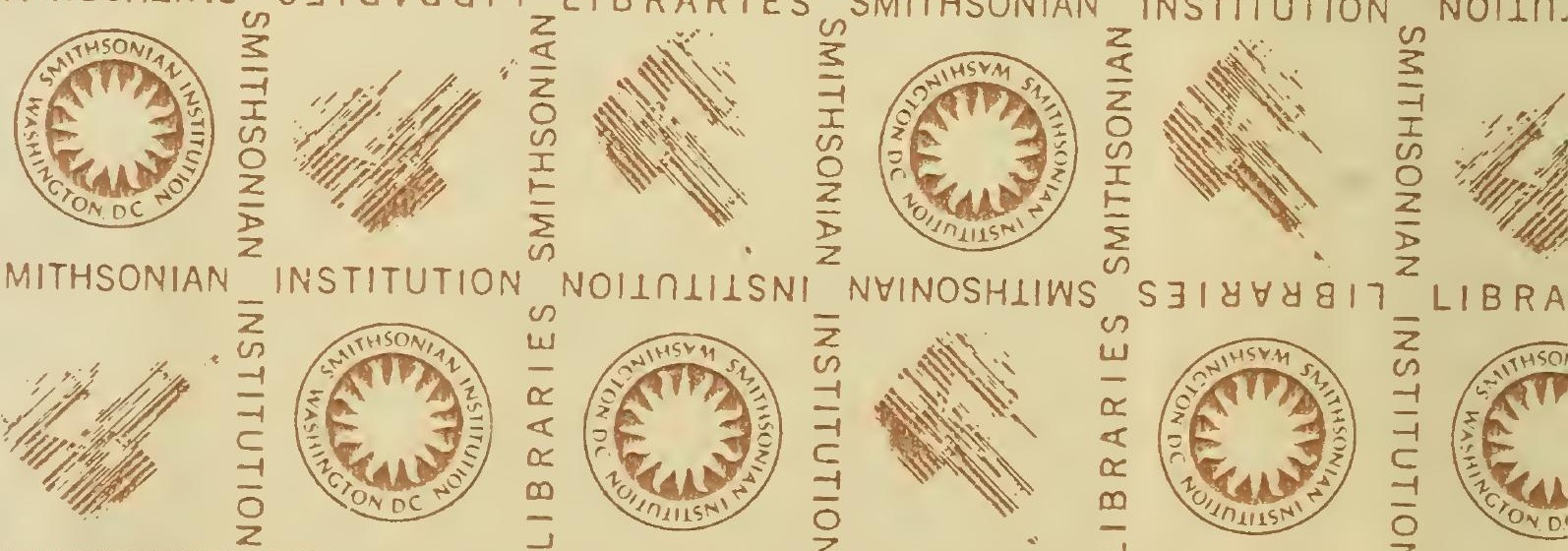
VINOSHIIWS

S $318 \forall 8917$ LIBRARIES
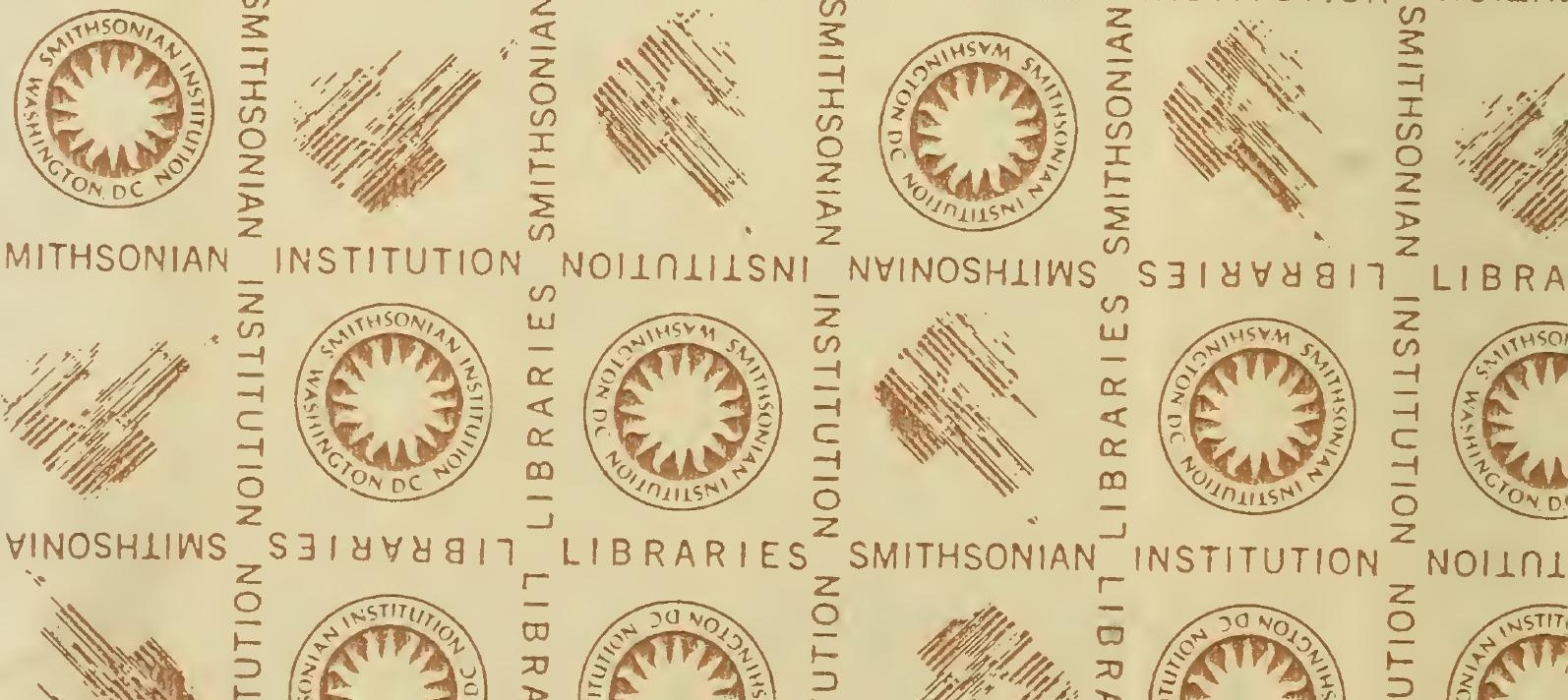

NSTITUTION

NOIL 1

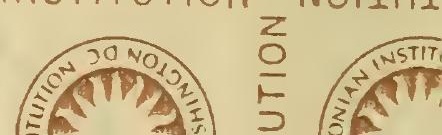




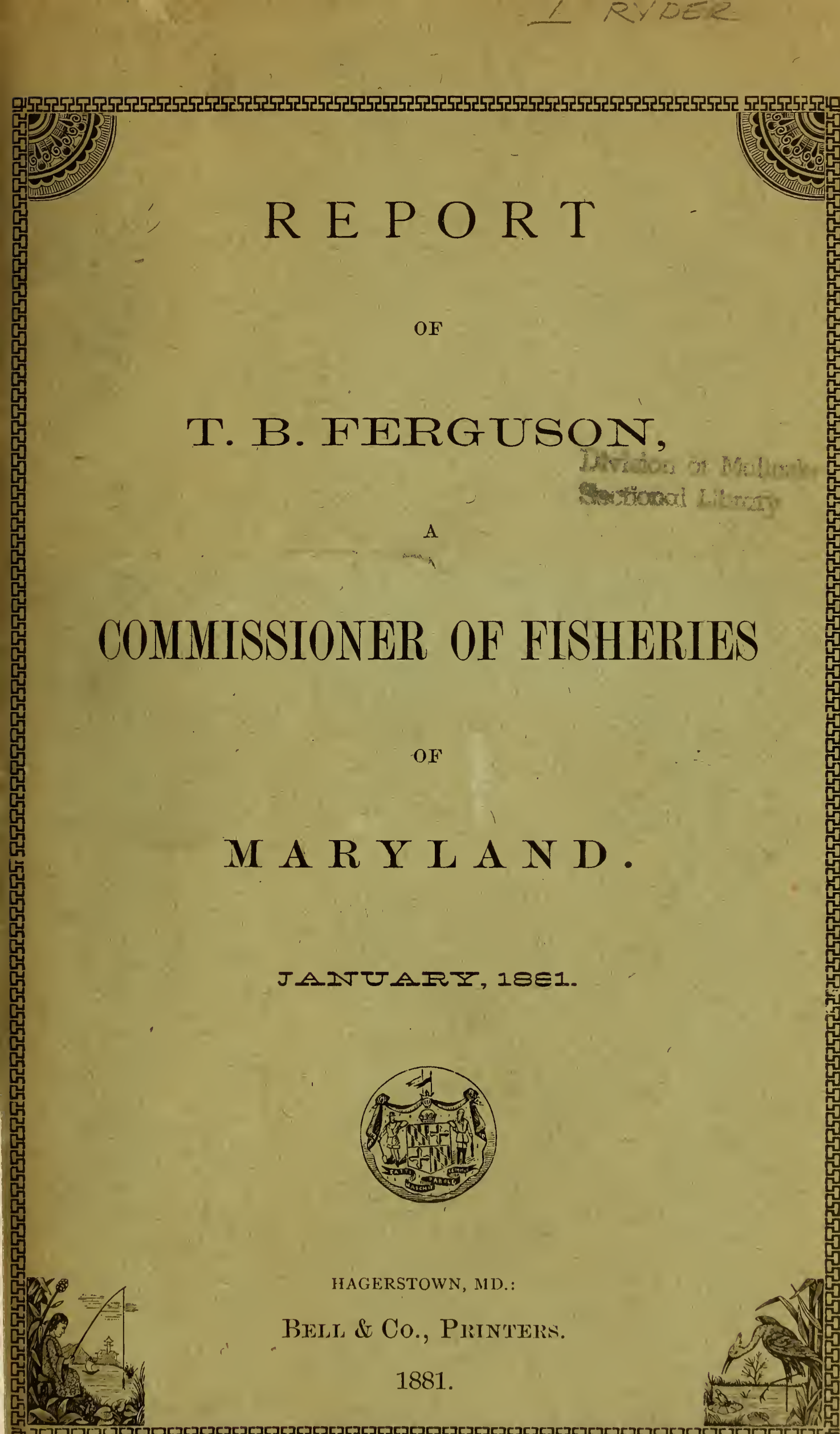




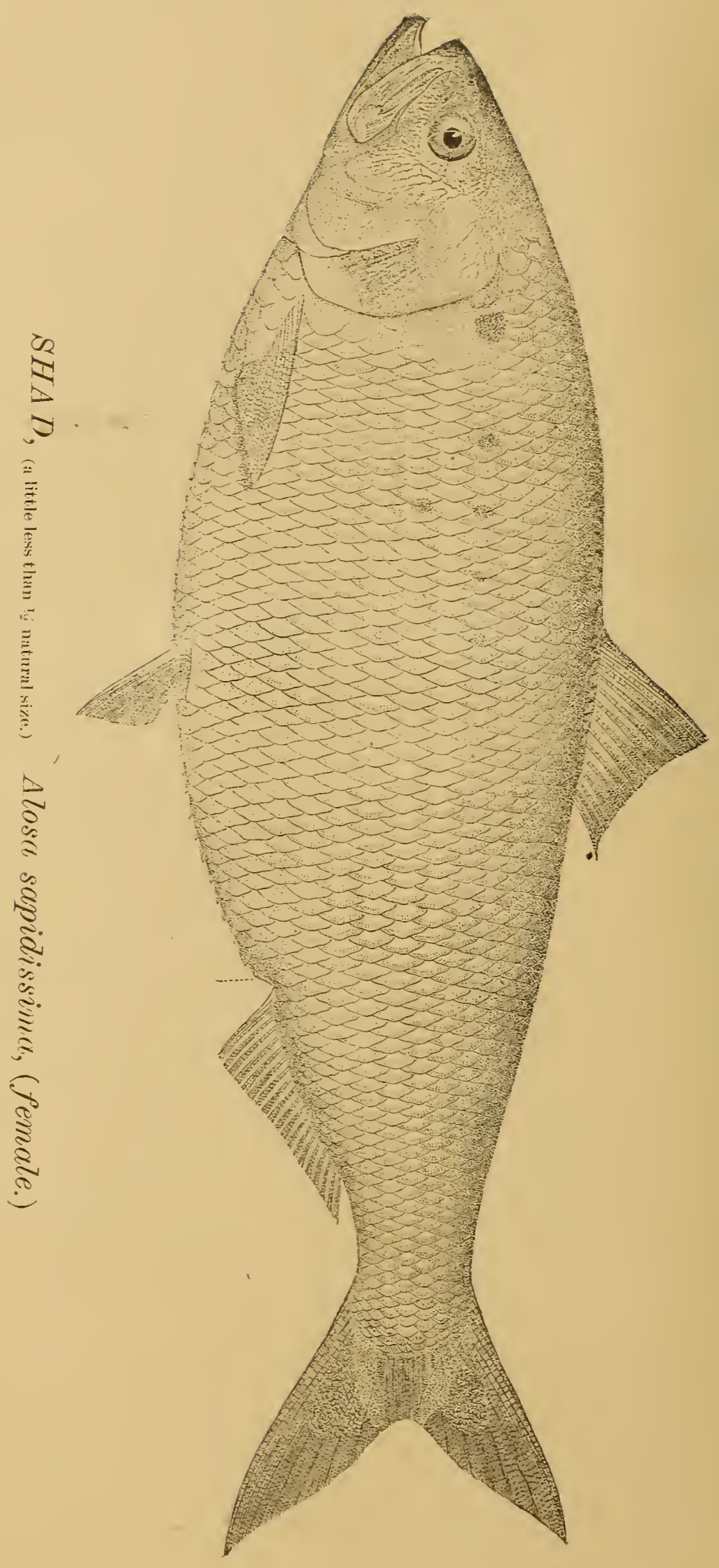




\section{R E P O R T}

OF

$$
\text { Eactional Iibrary }
$$

\section{COMMISSIONER OF FISHERIES;}

M A R Y L N D .

JAITUAFT, 1881.

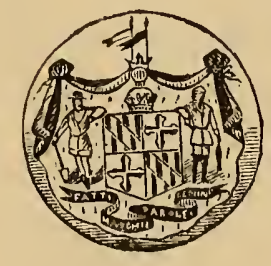

IAQERSTOWN, MD.:

Bell \& Co., Printers.

1881. 
<smiles>C1=CCCCCC1</smiles> 


\section{REPORT.}

\section{To his Excellency. WTLLLAM T. HAMILTON.}

\section{Governor of Maryland.}

The following Report contains only an account of the operations of the Maryland Commission so far as conducted under my own supervision. Chapter 150 of the laws of 1874, providing for the appointment of Commissioners of Fisheries, requires "that one of the Commissioners shall come fiom the Eastern, and one from the Western Shore of the State."

It was agreed, as this law seemed to direct such a comrse, that the details of the work of the Eastern Shore should be conducted by my colleague, and the work in the western portion of the State should be directed by myself.

To enable us each to carry on the operations in our special sections the appropriation for the year 1880-81 was equally divided between.us.

The work of investigation, propagation, distribution, etc., has been conducted on as an extended a scale as the means at my command permitted. The details of these operations, inchuding a distribution of $1,500,000$ shad and 690 carp in waters wholly within the eastern section of the State, dirertly under my supervision, will be found in the following pages.

The young fish deposited at the head of the Bay will be as well for the benefit of the inhabitants of the one shore as for the other, for, on their return from the sea, they are taken by our citizens on either shore in the common water's.

The year 1880 has been a very important one in the 
history of the Maryland Fish Commission, not only on account of the success attained in the attempted propagation of several varieties of valuable fish by artificial means, but because of the accumulated proofs which have been afforded of the success of the effort to fully restock the waters of the State with shad.

In my Report of January, 188(), relating to the operations of the Commission during the year 1879, it was shown that there had been a rery marked increase of shad for that rear at those points near the head of the Chesapeake Bay and in the Potomac River, where complete records had been kept. During the spring of 1880, this increase was even more decided, as the catch for that season not only exceeded, very largely; the returns for any one of sereral previous years: but also, and in a rery marked degree, the catch for 1879--the year immediately preceding.

The following tigmes, compiled by Col. Marshall McDonald, from returns secured from the various sunces of information made arailable by the investigations of the Census Bureau for the Census of 1880, show most clearly the effect which the operations at the head of the Bay, and the large deposit of young shad in the Potomac River, have had upon the vield of those waters, for the catch of shad at the Head of the Bay and in the Susquehamna River from 1870 to 1871 was as follows:

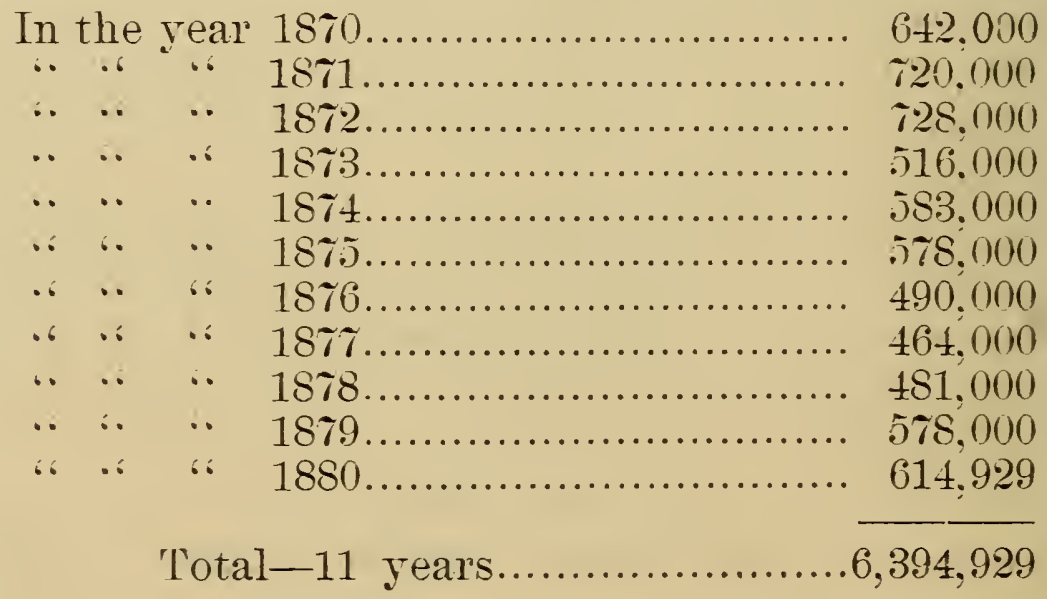


The average catch for the eleven years, given above, we find to be 581,357; the average catch of the first five years was 637,800 , and during the next five years this average was reduced to 518,200. This average, although a decrease from the arerage of the preceding five years, was considerably increased by the comparatively large catch of the spring of 1879--the first year that the product of artificial propagation was materially felt.

If we eliminate the catch of this year and take the average of the fom preceding years-that is $1875, ' 76$, '7\% and '78-we have an average yield for those years of 402,600 , but the catch of 1880 was 614,929 , an increase of 33,572 over the averag'e catch for the whole eleven years, and an increase of 96,729 over the average for the fire preceding years, including the year 1879, and 212,329 over the average of the four years inmediately preceding the return of the fish produced by artificial means.

statement showing amount of fish sold in Washington and Alexandria from 1865 to 1880 inclusive.

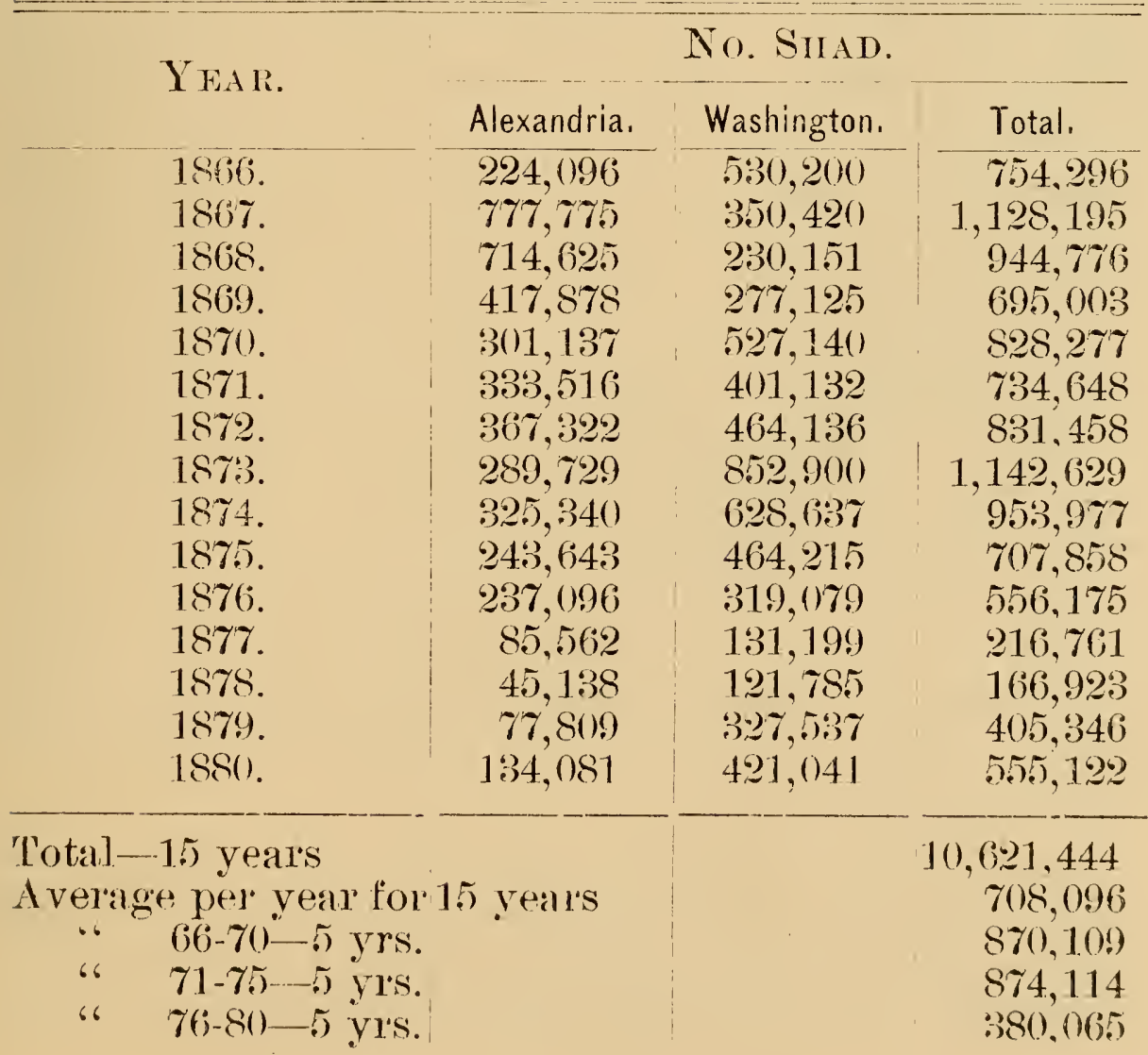


For convenience of reference these statements have been dereloped in the accompanying diagram. Unfortunately. no reliable records of the tisheries at the head of the Bay and the mouth of the Susquehamna River for the years jrior to 18\%, could be procmed : and. consequently, no such comparative diagram, or statemient, of the morement of the fish previous to that time can now be made. Pefore analyzing the diagram let us glance at the table showing the amount of fish marketer in Washington and Alexandria during the last fifteen rears; the records of sales in these two cities indicating. pretty accmately. the vield from the Potomac Rives. perhaps ten or twenty per cent. of the total amount being taken mb by the inhabitants of the adjacent country.

Assuming. then. that the number of fish sold in the two cities named represents the rield of the Potomac. we have a total catch of $10,621.444$ shad tor the tifteen years from 1866 to 1880: giving an arelage of s70,109 for the first five years: 874.114 for the next fire: and 380.065 for the period irom $18 \% 6$ to 1881 : and showing a rery remarkable decrease in the rield from this river. The rield for the second tive years, that is, from $18 \% 1$ to 1875 , although apparently greater than the arelage of the previous five rears. Was. no donbt, the result of more extended fishing: as romparatively few tish rele taken in 1866. in consequence of the fisheries not haring recorered from the effects of the war. and of the fishermen being withrut equipment. It will be observed that this decrease would be eren more marked but for the catches of 1879 and 1880: as, in the last mentioned year. when the results of artificial propagation began to be realized, we have 505, 122 -an increase of more than 200.000 orer the arerage rield.

The arerage of the preceding five rears. again. was enlarged by the exceptional yield of 1873 : but the large catch of this year was probably owing to the prevalence of easterly winds and other meteorological influences: as 



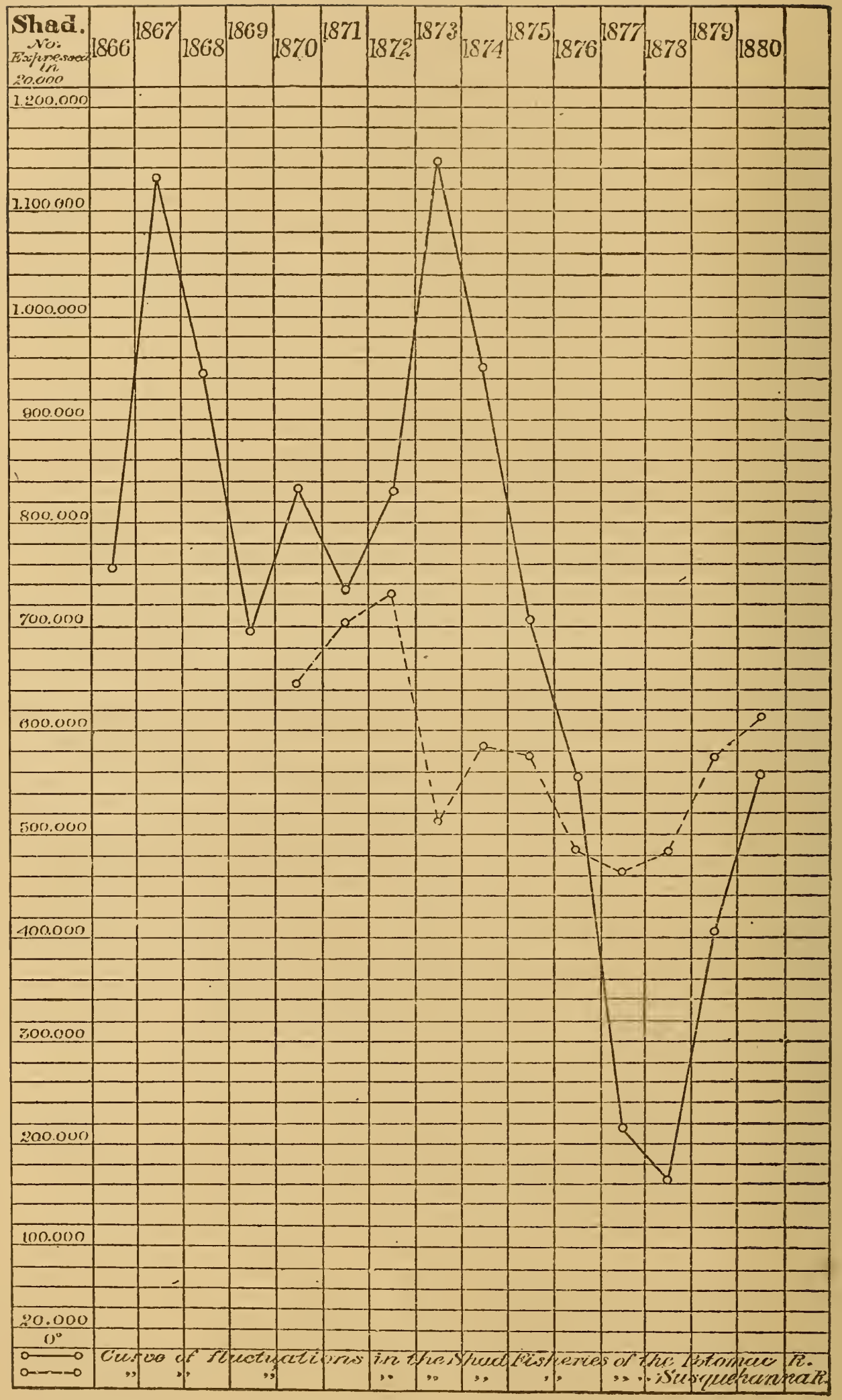


we find, by turning to the table of the yield on the Susquehanna, that the minimum catch for that river occurred the same year. The increase in the Susquehanna for 1880, however, was as marked as that in the Potomac; thereby clearly indicating such increase as being the result of the deposit of the artificially produced fish in both these streams.

The diagram will further show that 1870 -the first year in which it is possible to compare the yield of the two localities-was comparatively a good year for the Potomac fisheries and a $b a d$ one for those of the Susquehanna. The next year (1871) showed a decrease in the Potomac, with a corresponding increase in the Susquehanna. The following year-1872-the catch in the Susquehanna increased only 8,000 and that of the Potomac 96,810.

We next find the year 1873 to have been one of great abundance in the Potomac, and of great scarcity in the Susquehanna. In 1874 the Potomac decreased from $1,142,629$ to 953,977 ; while the Susquehanna increased from 516,000 to 583,000 .

We recognize in these statements the inevitable result of successive years of over-fishing ; of disturbing the fish on their spawning beds ; and of preventing them, altogether, from reaching such beds. The diagram indicates a continued, though somewhat irregular, downward tendency in the yield of the Potomar from 1873 to 1878 ; and of the Susquehanna from 1872 to $187 \%$, the loss in both rivers being finally arrested by the same means.

It will be remembered that the work of shad hatching was commenced in 1875, and was continued the following year-principally at the head of the Bay. In 1876 and $187 \%$ large numbers of young fish were released; and in 1878 a slight increase of shad was observed in the water's of the Bay-a remarkable feature of this increase being the preponderance of small male fish. In 1876 our operations at the head of the Bay were not prosecuted on a 
sufficient scale to enahle us to transfer many of the roung fish to the Potomac: but the numbers deposited in that river were increased from rear to rear, until. as will be seen by reference to the table of distribution to he found on page 4:3. 14.350.000 were deposited dnring last season.

As the Susquehanna region had the adrantage of at least a rear in the work of artificial propagation. we find that the ascent of the curre appears first upon the chart for that river. In 1Sis the rield of the Potomac had reached its lowest figure. 166,923. From this point we have a marked increase in the vield of both rivers. Whereas, prior to our efforts to repopulate these streams. there was almost always a decrease in the one whenerer any decided increase was observed in the vield of the other.

The increase of the rear $188 n$ was even more marked when we take into consideration certain meteorological intluences and their effects npon other localities. It happened that during the early rum of the shad in Chesapeake Bar southeasterly gales prerailed which must have driven the fish into Míbjack Bay in large numbers while seeking their natire waters of the Potomac and the susquehanna. since a much larger number were taken at the month of the York River and in Mobjack Bay during last season than had been captured the prerious rear-the catch being increased from 179.374 in 1879 . to 239. 804 in $188(1$.

\section{INTESTIGATIONS}

The erents of the rear $18 s 0$ hare not only demonstrated berond question the truth of the theories which have been adranced, and on which the work of the Maryland Commission has been been based: but they have also opened up a new field for the usefulness of this Department: and it is now quite certain that the work of artificial propagation can be extended to those fishes whose habits have hitherto been little known.

The inrestigations of the last season indicate that the 
fishes inhabiting the salt water exclusively can be as readily propagated, artificially, and increased to as unlimited an extent as the anadromous fishes with whose spawning habits we had been more thoroughly acquainted. The necessity which compelled those fishes--the shad, herring, salmon, etc., which spend most of their lives in the salt water--to enter the rivers for the purpose of spawning enabled us the more readily to study their breeding habits at the time of such annual migration. These varieties, therefore, became the objects of especial care and attention in the infaney of the Commission's existence.

Experiments conducted during last season have demonstrated our ability to hatch and distribute several varieties of fishes, which inhabit our salt water solely, to the same extent as has been accomplished in the case of the shad, and, indeed, it is quite possible that the Bay mackerel may be propagated on a yet larger scale than has been attempted with the shad itself.

About the first of .July of last year. I rereived from Messrs. Marshall McDonald and R. E. Earll, who were employed mpon that portion of the work of the 10th Census which relates to the fisheries of onr coast, an intimation that the Bay mackerel were spawning in Mobjack Bay, and that ripe fish, whose eggs could be readily impregnated by artificial means, were to be had in some numbers from the pound nets operated in that locality. I proceeded to Mobjack Bay, aceordingly, in the steamer" "Tookont," and succeeded in obtaining a sufficient number of ripe fish of this variety, and also of the porgy, and some other sea-fishes of less importance, to enable me to determine what were the best forms of apparatus to be used in their manipulation. As the immediate object of $m y$ investigations was to determine the proper manner in which work should be conducted in the future, rather than to attempt the work itself at 
that time. on operations were restricted ahmost exclusively within experimental limits.

Prof. Baird, L. S. Commissioner of Fish and Fisheries, having kindly sent with me Prof. John A. Ryder, a young naturalist of thorongh training and expert in microscopic work, we were alble to study the embryology of the mackerel and porgy in a very thorough and satisfartory manner. The result of Prot. Ryder's investigations will be found in a paper prepared hy him upon this subject, and which will be published in Prof. Baird's report to Congress.

As the eyg's of the mackerel. mnlike those of the shad, are somewhat lighter than water and manifest a consequent tendency to float upon the surface, the apparatus used in the cultivation of shad camnot be efficiently employed in their nanipulation. It is, therefore, necessary that some other form of appalatus should be devised, as that used in the shad-hatching operations is so constructed that a current of water fluws in at the bottom, buoying up the eggs. keeping them constantly in motion, and monentarily bringing fresh particles of water in contact with each egg.

snch a coment. either in the conical ressels (1) in the cylindrical plunge loukets-both of which forms of apparatus have been described in previons reports-acts agcinst the gravity of the egors of the shad: but in the case of those of the mackerel. and of all others that have a tendency to float. the current alcts with snch tendency and canses the eggs to pile in masses at the surface of

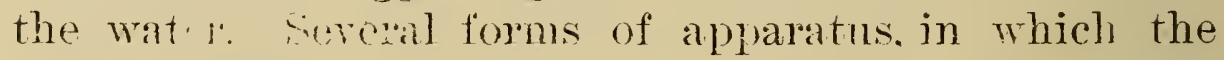
direstion of the curent is reversed, have been experimented with, and are fomd to art most satisfactorily.

It is hoped that during the next season the work can be conducted at the moper places and on a sufficiently large scale to enable us to determine which form of the vessels that have already been experimented with can be operated with the hest results and with the greatest 
economy. Ripe mackerel can be found in considerable numbers in the lower part of the Chesapeake Bay, and it may be necessary, in order to conduct the work on a sufficiently large scale, to collect and hatch the eggs outside of the limits of the State, but the young fish can thereafter be very readily transported to the upper portions of the Bay.

The investigations of the past season have developed the fact that a considerable number of ripe mackerel may be secured in the neighborhood of Crisfield, and several fishermen, who have been employed in the capture of this fish, testify that it has not been a great many years since they could be found as far up the Bay as Baltimore, the mouth of the Patapsco River, and elsewhere.

It is certain that the number of this most valuable fish has been very materially diminished in the waters of the State, and that they are beconing more scarce every year. It will, doubtless, require several years to restore them to their former abundance, and to make the catch plentiful enough to furnish a sufficient number of spawning fishes to warrant the estalolishment of hatching-stations high up the Chesapeake Bay. But as the fish can be very readily transported, the proper mode of proceeding would seem to be to hatch them at favorable places, where they can be had in large numbers. and transfer the young from thence. It is quite likely that they will return periodically to the localities where they were first deposited, for this habit seems to be as strangely characteristic of the coast fishes as of those which inhabit or frequent more inland waters. By way of evidence in support of this expectation, I would refer to the experience of the U. S. Fish Commission in the propagation of cod, in Gloncester Harbor. Inumg the winter of 1878 Prof. Baird established a small experimental station at this point and succeded in hatching out some millions of young cod. These were liberated in the harbor at Gloncester, and the following summer and fall young 
cod, an inch or two in length, were frequently seen in the harbor, none of the fishermen or inhabitants of the town having ever before noticed the young of this fish in those waters. Young fish a year old, and measuring six or seven inches in length, were also taken the next season, and in considerable abundance, in the same neighborhood.

\section{FISIT-WAXS.}

Having demonstrated the efficiency of the means employed to increase the yield of shad and other migratory fishes, it has now become essential to the thorongh success of the work and for the distribution of its benefits to all parts of the State that means be provided for the ascent of these fish to localities from which they are now debarred by natural and artificial obstructions. Although there are no such obstructions in the Susquehanna within the limits of this State, yet the work of restocking the river proper, and of increasing the supply of fisn at its month would be very materially assisted by opening the river to its sources, as this would not only enlarge the spawning grounds to a proportionate and very considerable extent, but would, at the same time, afford nore and better opportunities for the capture of ripe fish.

The construction of proper fishways in the river, in Pennsylvania, and the discontinuance of the use of fishweirs along the entire length of the river would very quickly yield the best results to the citizens of both States.

The interruption to the progress of fish in most of the rivers of the eastern portion of Maryland consists mainly in the means which are employed for their capture. This matter, howerer, is within the control of the inhabitants of those sections, to whom I would earnestly recommend the discontinuance of the use of such methods.

Among the principal streams of the Wrestern Shore we 
have the Gunpowder River, which is obstructed by a dam of recent construction, a part of the system for supplying the city of Baltimore with water. This and other minor obstructions should be provided with fishways, and if the shad, herring and rock were thus allowed free access to the upper waters of the river, the fisheries below the dam and at the mouth of this stream would soon be vastly improved.

The Patapsco River is also obstructed by many dams, none of which have been provided with effective fishways, although they are especially required by law.

In order to illustrate the practicability of restoring the shad, herring and rock to waters in which they were formerly abundant, but where they have since become unknown, I requested Col. Marshall McDonald, the Commissioner of Fisheries of the State of Virginia, who had made the construction of fishways a specialty, to examine the Patuxent River and advise me as to what could be done on this stream.

If the shad could be brought back in numbers to Laurel, after having disappeared from the river for years, the citizens of Maryland would be satisfied as to the good that would be accomplished by the erection. of fishways - over all of the artificial obstructions in the State.

That many miles of the Patuxent River, at least, can be opened to the migration of these valuable tishes, will be seen by the following report made as the result of the examinations of that river:

\section{Obstructions to the Ascent of Fish on the Patuxent.}

\section{MAJOR T. B. FERGUSON,}

Commissioner of Fisheries for Maryland.

Dear Sir:-Maj. O. C. Henderson, whom I sent to ascertain the number and character of the obstructions to the ascent of fish on the Patuxent, reports as follows:

'The first dam is at Jericho Mills, about three hundred 
yauds below R. R. Bridge (B. \& P. Railroad), about one and one-hali miles from Bowie.

The dam is built of brush and stone, and the difference of water level, above and below the dam, is 3 feet.

At low stages of water none passes over the clam. Ordinarily, in April, May and June surplus water passes over the dam in sufficient quantity to feed a fishway withont interfering with mill supply.

At the present time no shad or rock ascend to this point, and rarely a herring. This is dne to the complete obstruction of the river by nets and weirs below.

The 2nd obstruction reported by Major Henderson, is the dam of the Iron Works Mills, four niles below Laurel and one and one-half miles from Contee station, Washington branch B. \& O. R. R. The difference of water level at this dam is only abont 2 feet.

At Avondale Mills, about one and one-half miles below Lanrel, is a stone dam abont five feet high, which is the third and last obstruction on the river until you ascend to the dam of the Lamel Cotton Mills.

The dam of the Laumel Mills is built of stone, and is about 28 feet high. At ordinary summer stages of water, there is no discharge of water orer the dam. The whole stream is diverted to furnish motive power to the cotton. mills, and at very low stages of water this is supplemented by steam power.

The river may be opened to the Laurel Mills so as to permit free passage of tish with comparatively little trouble and at a very moderate expense.

Below this point the supply of water is considerably in excess of the amount used for notive power, and a sufficient quantity of water may be discharged throngh the fishways to invite the ascent of shad, which are a timorous fish, and indisposed to enter a way discharging an inconsiderable volnme of water.

The general plan of fishway I would recommend for the three lower dams of the Patuxent is represented in 
the areompanying cut, which represents a tishway discharging a rolume of water from 1:2 to 15 inches deep and ten feet wide.

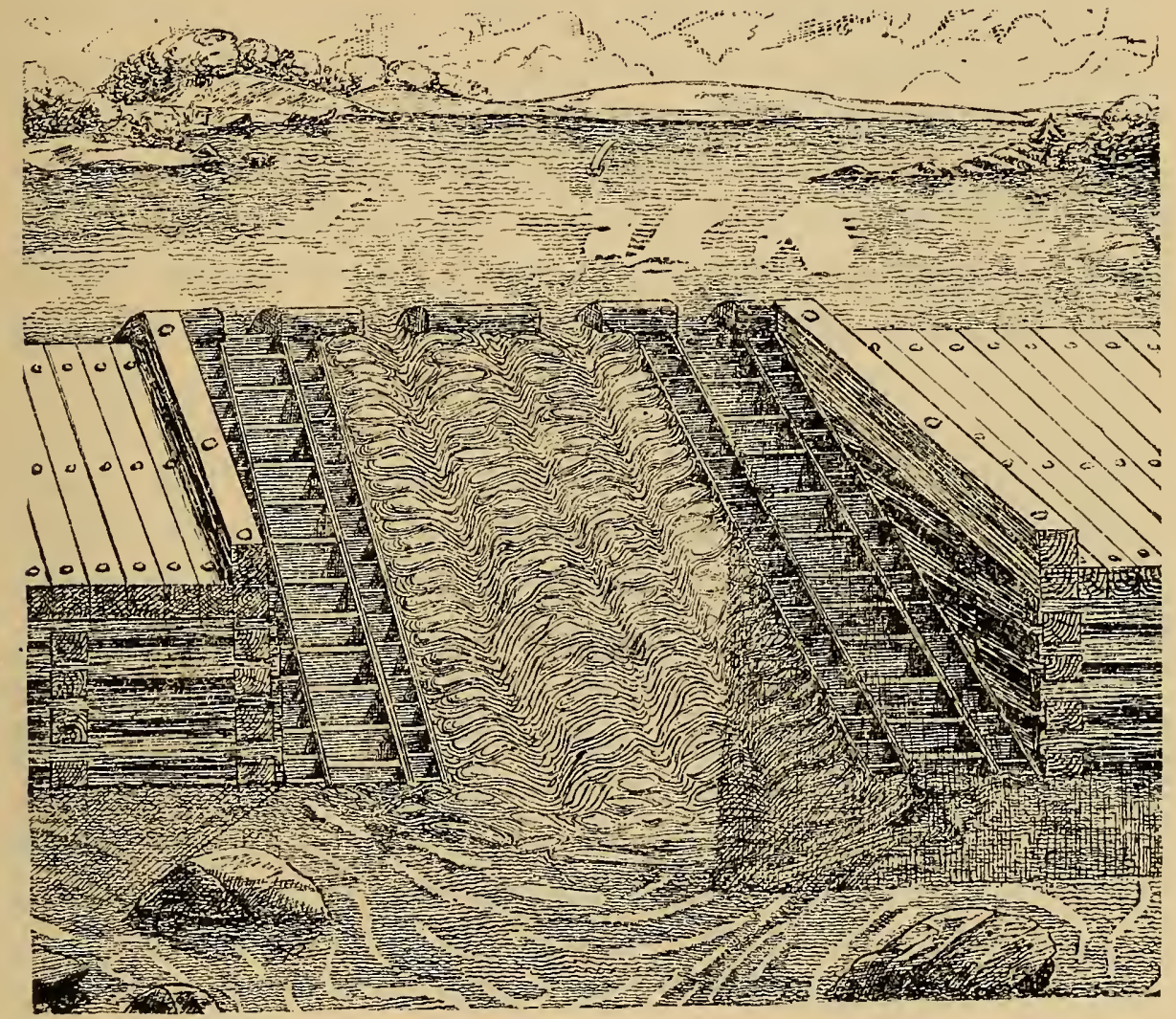

\section{MCDONALD KISHWAY,}

Showing working at low water stage.

For economy of water supply at low stages of water, the middle section tive feet in width is depressed below the plane of the sides, so that only this middle section takes water when the river is low. In full stages of water the whole breatth of the fishway discharges.

Fishways shonld always, when practicable. berecessed into the dam, so that the discharge from the lower end of the fisloway will be on a line with the lower face of the dam. Where not practicable to recess the fishway as indicaterl, then it shomld be placed next to the bank and a sloping apron plareal in the angle betwen the fishway and the dam. so as to establish an unintermpted line of overfall from the month of the fishway to the dam. 'This 
construction will in the case of low dams practically place the mouth of the tishway in the line of the face of the dam.

In the case of high dams it will probably be better to build the fishway with a return or elbow. so as to make the discharge at the face of the dam.

In the case of the Laurel Mills dam, there being no surplus of water to deal with ordinarily, the fishway may be made much narrower and the water discharge proportionally reduced; a width of two or four feet for the water way would in this case be enough. Such a fishway would provide access to the upper waters of the Patuxent for the salmon. the herrings and all the anadromons or rirer species, except the shad. I doubt if the rolume of water would be sufficient to induce the ascent of the last named species in considerable numbers.

I also examined the dam at the Relay Honse. on the Patapsco. This is a timber dam about $i$ feet high, and is the first obstruction on the river above tide-water. Upon the dam there is now a crude fishway of the old style, built by the uwner, I presume. in conformity to the requirements of the State law.

It is not probable that the State will enter upon the enforcenient of a law making the erection of tishways obligatory, until their efficiency has been rested and approved by yonr State Commission.

The dam above mentioned furnishes an admirable location for making the experimental tests required.

I have therefore carefully examined the locality, and submit to you the general plan of a fishway. such as I think well adapted to meet the particular requirements of the case, and if approved. will serre as a model for subsequent constructions.

The cost of this construction will be from tive to eight hundred dollars, varying with the cost of securing the foundations on which to build the superstructure.

Tery respectfully yours,

M. MCDONALD. 
SHAD-Alosa sapidissima.

The co-operation of the U. S. Fish Commission, during previous years, having proved so important in general results and so advantageous to the State of Maryland, I naturally sought a continuance of such co-operation and assistance in arranging for our spring work.

I was most fortunate in securing the detail of two machinery Barges, together with two others, which had been furnished with quarters for the employes, for the station at the Head of the Bay, to which they were transferred in the latter part of April.

Prof. Baird had obtained from the Secretary of the Navy the loan of two steam launches which could be readily used in collecting the eggs of the Shad, both from the large fisheries and from the gillers operating in the neighborhood of Havre de Grace, I, therefore, determined to utilize the Steamer "Lookont" on the Potomac River. As she was provided with hatching apparatus sufficient to accommodate from 600,000 to $1,000,000$ eggs, we confidently expected to hatch out several million eggs during the fishing season on this river.

POTOMAC RIVER.

During an inspection of the fisheries on the Potomac River, on the 26th of April, I chanced to arrive at Mr. Skidmore's fishery, at Moxley's Point, abont 6 o' clock in the afternoon, as the seine was being landed, and found unexpectedly, a considerable number of ripe male and female shad.

About a quarter of a million of eggs in good condition were readily secured, but as it was considerably earlier in the season than we had ever before obtained ripe shad on this river, the hatching appartus had not yet been placed in running order, and, after keeping the eggs a few homrs in pails, I emptied them into the Eastern Branch of the river at a point near the Navy Yard.

Finding the season so unusually advanced I immedi- 
ately -ermpri the rquilment uf the stedmer for the spring work and commenred actire opelations on the fth

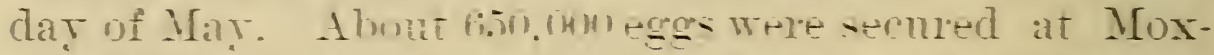
ley - Point un the -ame night. and ats this numbel completsy tilled the alpluater w the stramel. the work of

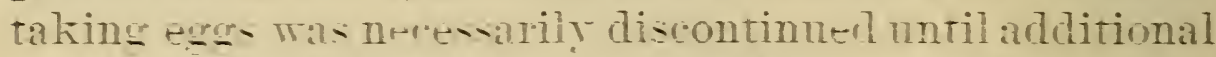

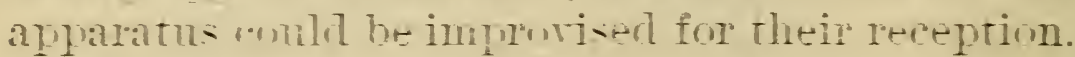

This sucres on the Potomal: it slmuld to remembered. Was whol! withumt prevelent and as we had provided means unl fur harehing ror in such numbers as we had hitherto hwen able to serume. We were totally unprepared to handle the grantities which were obtainable at this period.

In this state of atfairs I again looked to Prof. Baird for asistance. and through his inthence secured from the Iavy Telartment permission to nse the hrdrant water in the Yary lated at 11 arhington. and also to put up aparatu- for dereloning the regs which might be gatheled by the ".Lonknut."

Thr assistanre whir.l was whtained from the Marhine Shops at the rald enabled ns. in a fer dars. to hare a dozen cones Ionning. Which was as mant as I thought it necesaly to prowide. for with these we wele prepared to take cillw of fromb tweltr tw eighteen hundred thousand egos. and I did not horpe to hare more than this number on hand at one time. It most be horne in mind that it only lequired about thret dars from the time that the egas were taken for their full derelopment. when they coldd nither hr depoited in local waters op transfered to other puints. learing the ressels fret to receive fresh supplies. As the "Lookont." howerer. gathered from one to two million egos a might during this period. the apparatus which was erected was taxed to its ntmost capacity. and additional mes wele added as fast as ther could be manufactured until. timalls. their number reached forty six exclusire of the half dozen on the bow of the "Lookont." which were used as receptacles for the egos as they 
were gathered, and for their transfer from the points below Alexandria to the Nary Yard. All of these vessels were simultaneously employed upon several occasions during this short season-some times turning out as many as 2,000,000 young fish in a day.

The details of these operations ma be found in the accompanying tables from which it will be seen that nearly $19,000,000$ fish were produced at this somewhat impromptn establishment. Of this number over $14,000,000$ were deposited in the waters of Maryland. The record of this distribution will be found on yage 43 , combined with that of the fish produced at Havre de Grace.

If this extraordinary success could have been anticipated, and sufficient apparatus in working order had been provided from the commencement of the season, I am quite confident that the total result above given would have been increased to over $30,000,000$. But when the records of the hatching operations on the Potomac River for 1880 are compared with those of other years, as given in previous reports, it will be seen that the organization of the work on such a scale wonld have appeared wholly unnecessary.

The Steamer "Lookout" continued her nightly trips down the river with varying success until the end of June.

As the law prohibiting the catching of fish after the 1st of June is utterly ignored on the Potomac, ontside of the District of Columbia, I determined to gather all the spawn that conld be obtained from the fish taken, and from them producing as many young fish as possible in order to keep "1) the future supply in this river. 'T'he experiences of this year on the Potomac are most important, not only on account of the magnitude of the work and of the results accomplished, but as affording a clear indication of the good results of our former efforts and as demonstrating how readily and surcessfully the work 
can be conducted in the future, so long as we can secure the valuable co-operation of the U. S. Government.

It is quite possible that the period of the runs of Shad in the rivers has a close relation to the time in which the young fish are oliginally hatched, and the early run may possibly be the result of the fish which are first hatched in any given season.

The disturbance of the fish for many years by seines and gill-nets has interfered materially with the production of young from the earliest spawners, and from this cause the early runs were gradually becoming exhausted. It is possible that as by artificial propagation we have been able to deposit young fish, produced from spawn taken from the early runs, the earlier schools have been increased, and we are not now dependent solely for the supply of the future upon the limited number of fish produced by the late runs, which spawn after the season is so far adranced that most of the seines and gill-nets have ceased their operations. 


U. S. AND MD. COMMISSIONOF FISH AND FISHERIES. RECORD OF TEMPERATURE OBSERVATIONS made at Wash-lington, on the Steamer Lookout, from May 4 th, 1880 , to June 18 th, 1880 ,
by W. P. Sauerhoff and Wm. Hamlen.

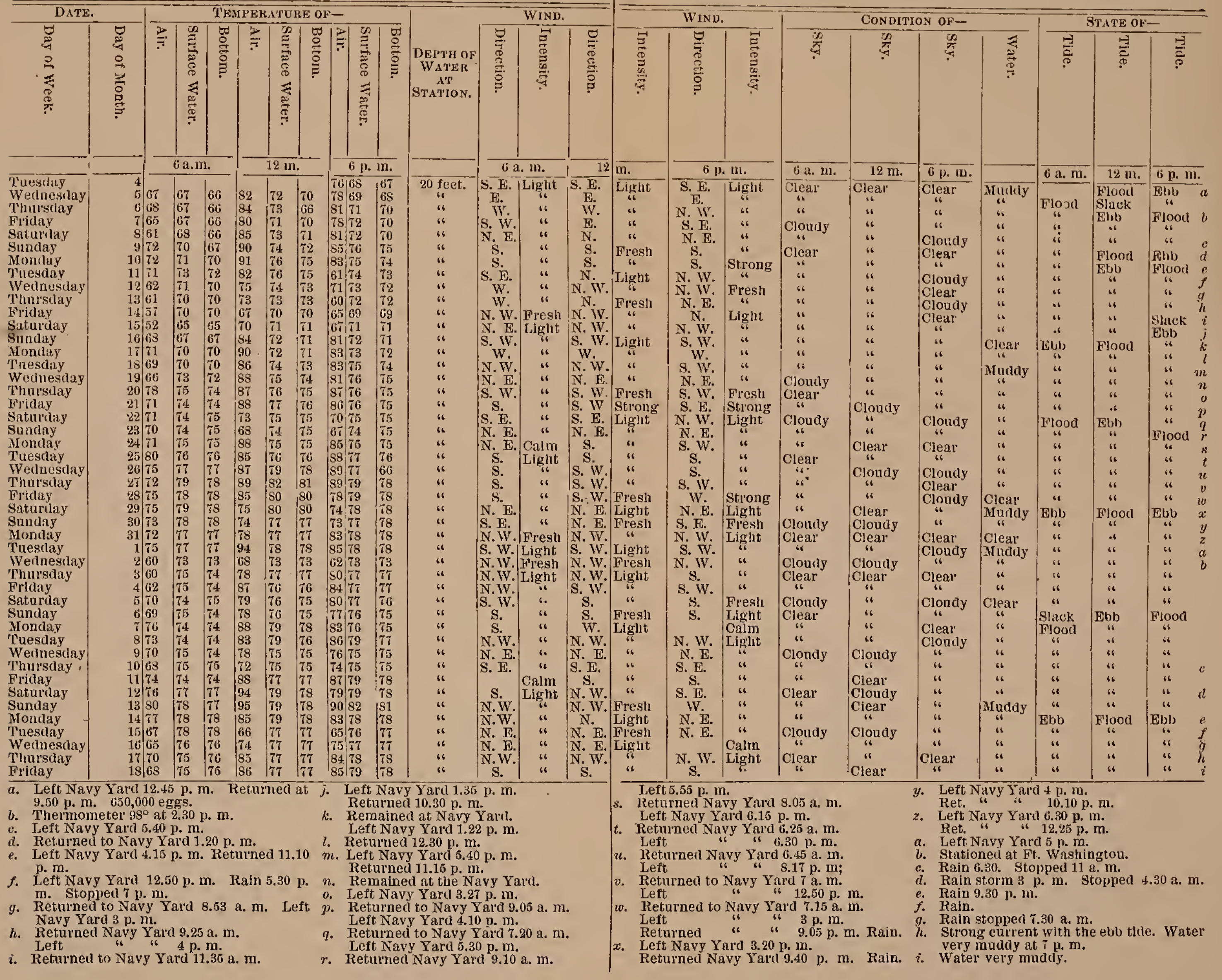





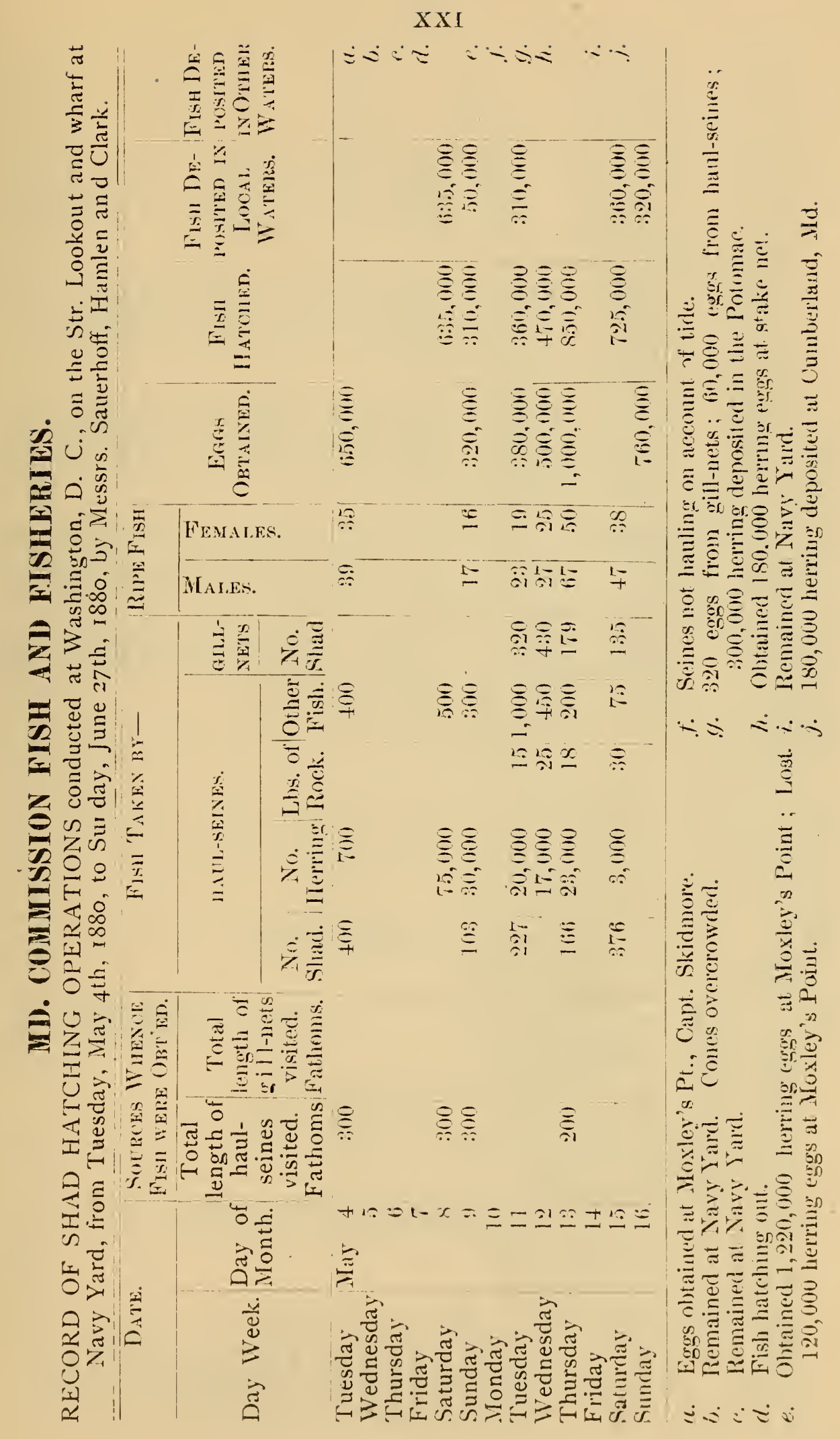




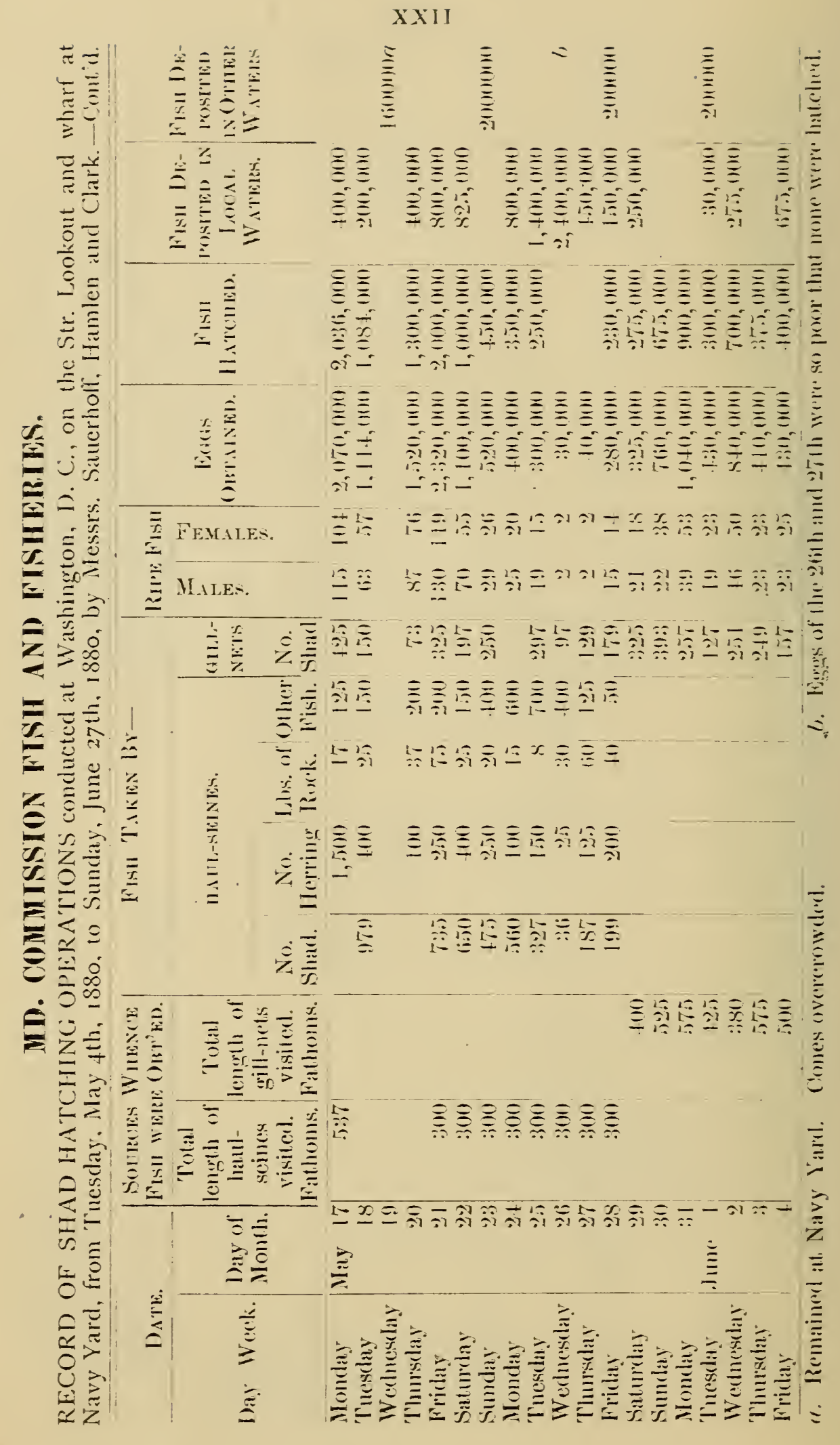




\section{XXIII}

$\sum_{0}^{8}$

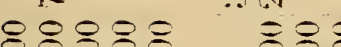

ఏ요

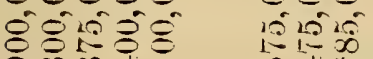

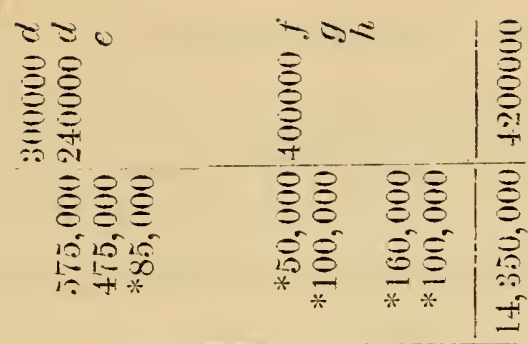

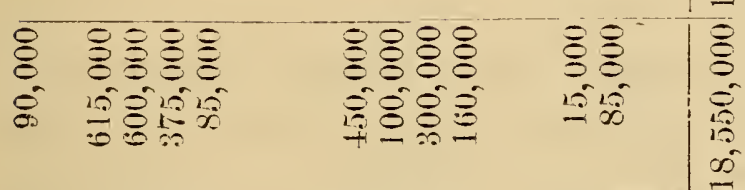

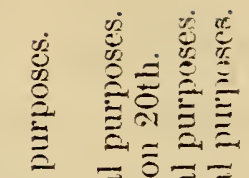

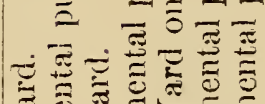

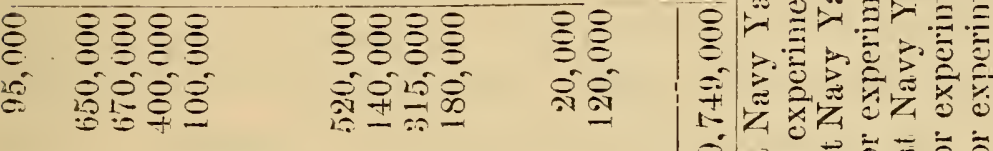

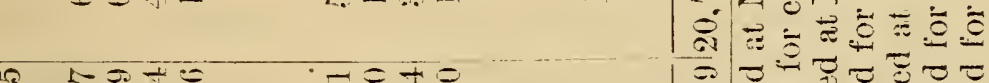

\begin{tabular}{|c|c|c|}
\hline 20 & 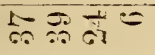 & $\bar{\therefore} \equiv \vec{\sigma}$ \\
\hline 15 & $31=\infty$ & $\Rightarrow 0 \cdot \bar{a}=$ \\
\hline 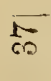 & 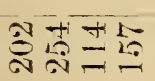 & $\stackrel{0}{=} i-\infty$ \\
\hline
\end{tabular}

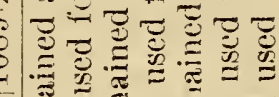

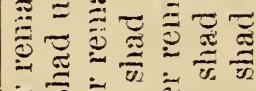

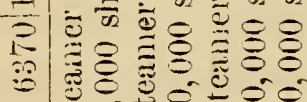

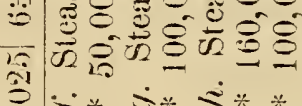

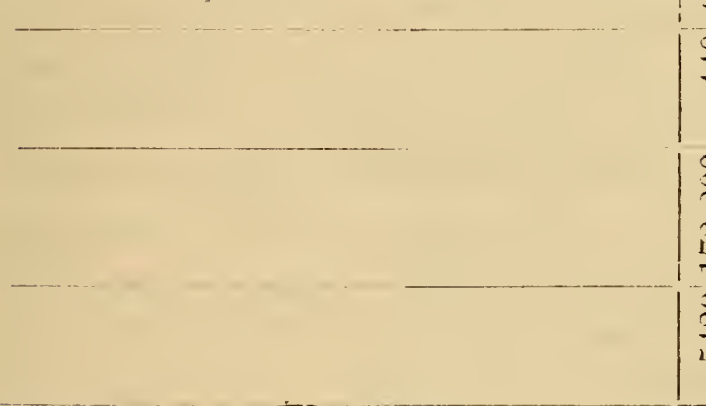

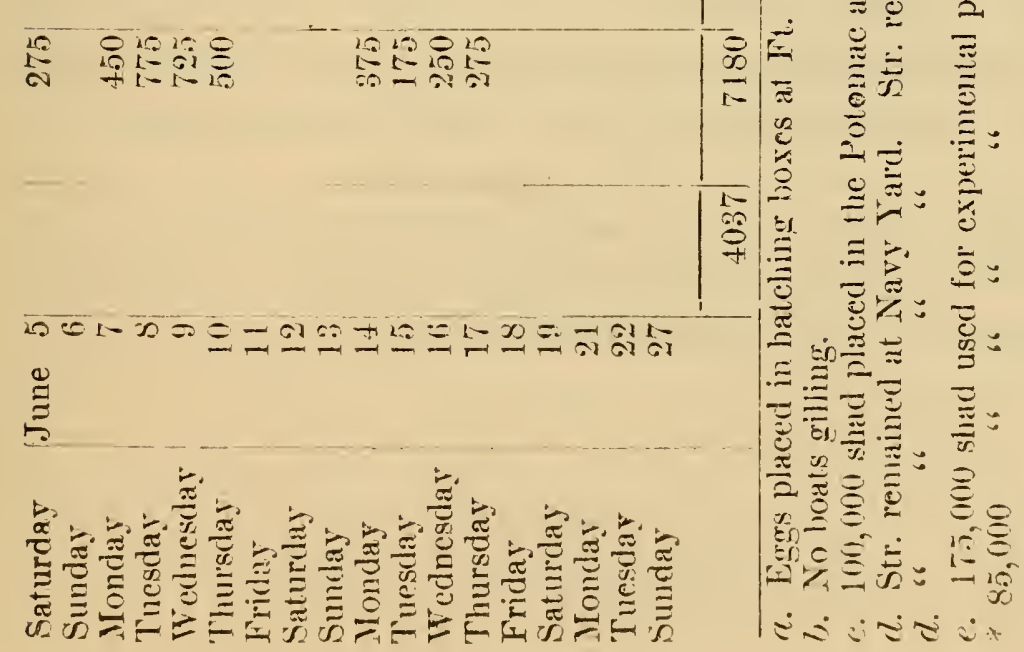

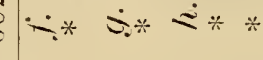


HATHE DE GRACE STATION.

This station was placed under the immediate charge of Mr. John S. Saunders of Baltimore, who had obtained considelable experience in shad work during his employment by the U. S. Commission in North Carolina. in the seasons of $1878-9$.

The barges, to which reference has hitherto been made, having been remodled and placed in thorough order during the time they were laid up at Baltimore, I directed that they should be transferred to Spesutie Narrows, a convenient and central locality, from which the large fisheries and the gillers could readily be reached. The entrance to this harbor had been dredged by the Engineer Department. to allow safe passage for the steam launches. During the early portion of the season, while the haul seines were being operated on Spesutie Island and on the Floating Batteries adjacent. these fisheries were visited daily and eggs obtained from them, as well as from the gill-nets which were drifted on the flats.

An extended drought, with a preralence of south-easterly winds. caused the salt water to back mp the bar, and the water became so brackish in Spesutie Narrows as to endanger the eggs. It was, therefore, found necessary on the 30th day of May to remore the barges from this locality to a point abore Harre de Grace, between Watson's Island and the Cecil Connty shore. This change of location in the midst of the season no doubt contributed materially torards lessening the results obtained at this station.

Particulars of the work conducted under the supervision of Mr. Saunders will be found in his report and journal which are herewith submitted. 


\section{$\mathrm{XXY}$}

Maryland Commission Fish and Fisheries,

Battmore, Md., Sept. 25th, 1880.

\section{MA.J. 'T'. B. FERGUSON,}

My Dear Sir :-Please find herewith enclosed a rough journal of operations at Havre de Grace during the months of May and June. In forwarding the same, I would make a few suggestions in regard to some changes which I think wonld be beneficial. There should be some cover or awning made to protect the cylinders in case of rain, as the drops kill the eggs and young fish, and we found it impossible to cover them with tops, the rain coning on us so rapidly. A folding awning could be easily arranged to drop in a few minntes.

There shonld also be a hinged plank placed on the sides of the barge to enable the men to walk aronnd the outside of it in order to examine the cylinders, place eggs in them and remove young fish, as we found it extremely difficult to do so from boats. This arrangement could be made at slight cost, and would not be at all unsightly. I consider the working of the cylinders as now arranged a great success. and after a careful examination think the results are fully a third more, in hatching, than are obtained in cones: the economy of labor and attention being very much in faror of the cylinders. There should be some improrement made in fastening wire bottoms to cylinders, since as they are now made, they break at the onter band and lose a great many young fish. I would also advise a net being placed under them to prevent eels \& $c$., from sucking the eggs through the bottoms. I woudd alsosuggest, for finture service, that a hetter class of engineers be employed, as a great responsibility is placed upon them, and they should be both careful and competent to repair any breaks $\&$ c, in the machinery. Six or eight first-class. reliable men would do more, I think, in getting spawn \&e. than a larger number; for it was my misfortune this season to be 


\section{XXVI}

troubled with quite a number, when the same results, and perhaps better, could have been accomplished with half the number of reliable men.

Very respectfully yours,

$$
\text { TNO. S. SA UNDERS. }
$$

April 29.-Cast off from City yard, South Baltimore. with three (3) barges in tow of tug boat "Mfohawk" at $10.15 \mathrm{~A}$. M., cast off" from tug "Мohawk" at 11 \&. M.: off Fells Point, and was taken in tow by C.S. Revenue Cutter "Ewing" to be carried to Spesutie Narrows, head of Chesapeake Bay. Harl heary wind from S. E. with rain all day. Arrived off Narrows at 5.00 P. M. Dropped anchor at 5.20 P. M. at Narrows where we remained all night on account of heary wind and rain. Steamer returned to Baltimore after seeing us safely anchored.

April 30.-Wind changed to $\mathrm{N}$. W about $1 \mathrm{~A}$. M. with heavy rain. Wind increasing until ahout 4 A. M. when it was blowing a gale. Had to let go all anchors, as also anchor Nachinery barge by itself and stem launch. Wind blowing a gale all day.

May 1.-- Wind calmed down abont $t A$ M. when all hands were called. Weighed anchor's and succeeded in getting barges safely moved in Narrows about $12 \mathrm{M}$. Left in Lamoh at $1 \mathrm{P}$. M. for Havre de Grace. where I telegraphed arrival \&e., to Maj. Ferguson. Retmed to Narrows about 4 A. M. Wind N. IV.

May 2.-Clear and pleasant. Had men cleaning up and regulating cones. Gave the steam lannch a coat of paint. Wind $s$. E.

May 3.-Clear and pleasant. Discharged colored cook on account of negligence and drunkeness. Placed Freedy in charge of kitchen. Sent men to gather spawn; they returned about $11 \mathrm{P}$. 


\section{XXVII}

M. bringing about 40,000 eggs. The eggs were very indifferent. Frank Farr reported for duty as pilot for Launch and brought colored boy to do temporary cooking. Wind S. W.

May 4.-Clear and warmer. Sent men out to the Batteries. They returned with about 275,000 eggs. Machinist Flynn and Fireman Slavin reported for duty. Wind gentle from S. W.

May 5.-Clear and pleasant. Reported result of taking eggs to Maj. Ferguson. Men went to Batteries, returned with about 150,000 eggs. Frank Courtney reported for duty. Wind during day N. E., E. and S. E. Received word that Maj. Ferguson would be down.

May 6.-Clear and pleasant. Sent Launch to Havie de Grace for Maj. Ferguson, leaving men at Batteries on way up. Maj. Ferguson arrived about 1 P. M. bringing Mr. Davenport and colored cook M. Robinson. Maj. Ferguson returned about 4. P. M. Lamch returned about $9 \mathrm{P}$. M. bringing men from Batteries. They obtained 475,000. M. Gleason reported for duty and was assigned to care of cones and hatching. Wind variable $\mathrm{N}$. to. W.

May 7.-Clear and pleasant. Sent Launch to Harve de Grace for mail, learing men at Batteries on way up. They returned about $8 \mathrm{P}$. M. bringing about 4(0),000 eggs. Turned much colder after sundown with heary wind from S. E. First egg's hatched. Figgs not doing well on account of being badly impregnated, as also stoppage of water by foul pipes. Mr. Davenport accompanying men at night.

May 8.-Clondy and overast. (Geared away about 11 A. M. Left for Baltimore at 9.02 and returned at 4 P. M. Acompanied men at night in getting eggs and retmod at 11 P. M. with 
550,000 . Great scareity of ripe male fish, cansing bad impregnation of eggs. Had inventory of scow taken. Colored boy (acting as cook) left.

May 9.-Clear and warm. Sent men to Batteries, gillers not being able to rast on account of heary wind. They returned with about 250,000 eggss. Wind S.. S. Wr.

May 10.-Clear with wind strong from S. W. Eggrs hatching out rapidly. No instructions as to distribution of fish. Received box containing the following articles: Small wrench, tallow pot, two $\frac{1}{2}$ inch round files, piece of packing and boat hook. Men returned about 9. P. M. with about 250,(0) egg's. Trind strong from S. IV.

May 11.--Clear and pleasant. Received orders to turn out all young fish in river above Havre de Grace. 'Turned ont at 5 P. M. aloove Harre de Giace 150,000 fish, and about 250,000 off Narrows. not having cans with which to transport them abore Havre de Grace. Sent Mr. Jarenport to Washington as ordered. Received bundle containing pillows. Visited Batteries. Large catch of shad (new run) but none ripe. Obtained abont 180.000 eggs from gillers. Great quantities of perch taken in - haul seines. Attempted to get egg's but was unsuccessful.

May 12.-Clear and pleasant. Wind strong during day from $\mathrm{N}$. IT. Sent $14.5,000$ young fish abore Harre de Grace. and also turned ont 100,000 off Narrows. Taunch returned bringing Mr. Darenport and colored boy, S. Robinson, also 11 U. S. 'ans, one bucket, one dipper, two tin syphons and two pieces hose. Men went out about $6 \mathrm{P}$. M. returning about $11 \mathrm{P}$. M. with 250.000 ). 
May 13.-Clear. Wind heavy from N. W. Sent 300,(000 young fish to be placed in river above Havre de Grace, at 9 A. M. Launch returned at $12 \mathrm{M}$., bringing bbl. containing lanterns and a package from Register \& Sons. Permitted A. Hamlen to go to Baltimore to see his brother, who had been seriously injured by an explosion of old shells. Thurned out 250,000 young fish in narrows, at 5 P. M. Obtained 200,000 eggs at night, and would probably have gotten more had it not been for heavy wind, which prevented gillers from going out.

May 14.-Clear and cold. Heavy wind from $\mathrm{N}$. E. Sent 270,000 young fish above Havre de Grace at 9 A. M. Mr. J. A. Ryder returned in launch. Wind moderate at night and men went out, obtaining 300,000 egors. Arranged a laboratory for Prof. Ryder. Mr. Herwood reported for duty.

May 15.-Clear and cold. Sent 215,(y0) young fish above Havre de Grace. Received by mail a draft for $\$ 100.00$ for incidental expenses. Sent Mr. Davenport and Mr. Simmons to Washington, as ordered. Men went out at 6 P. M. and returned with 750,000 eggs. Large number of female tish found, but very few males.

May 16.-Clear and pleasant. Had a great many risitors during the day. Sent men out at night and they retmined with 275,0no egos. Small launch arrived from $\mathrm{W}$ ashington about $11 \mathrm{P}$. M., in charge of Capt. I. Poplein, who reported as having been detained by heary winds.

May 17.-Clear and warn. Prof. Ryder went "1) to Batteries to examine spawn of perch, \&e. 
Was unsuccessful in getting any, but brought specimen of cat-fish caught at Osborne's battery. The Agent of the Pennsylvania Fish Commission arived about 3 P. M. for young fish. Delivered to him 200,000 which we sent in steam launch to Pt. Deposit. Mr. Wright visited barges to see working of his new fishhatching boxes. Found wire too coarse and had to carry them back. Men were very successful in obtaining eggs, procuring 780,000. This caused us to place a large number in cylinders, cones being full.

May 18.-Clear and pleasant. Sent the cat-fish obtained the day previous to Prof. Baird, at the Smithsonian Institution. It was pronounced an Albino. Mr. Heywood left at 8 P. M., having received a dispatch calling him home. Turned 250,000 fish in Narrows at 6 P. M. Obtained 420,000 eggs at night.

May 19.-Overcast, with wind from N. E. Sent 250,000 fish abore Havre de Grace at $9 \mathrm{~A}$. M. Obtained 600,000 eggs at night. Prof. Ryder busily engaged orer the development of young. fish.

May 20.-Clear and warm. Sent 275,000 young fish abore Havre de Grace at 9 A. M., and 200,000 at 3 P. M. Egg's coming ont rapidly. No room for them in cones, so had to use cylinders. Placed 200,000 young fish, from eggs obtained on 15th, off mouth of Swan Creek, at 6.30 P. M. Obtained abont 640.000 eggs at night.

May 21.-Clear and heavy wind from S. E. Sent 350,000 young fish, from eggs taken on 15th, above Havre de Grace, at 10 A. M. Delivered to Pennsylvania Fish Commission 250,000 young fish at 3 P. M. Placéd 50,000 in river near 
Pt. Deposit, and 25,000 in Narrows. Heavy gale from S. E., preventing the obtaining of egros.

May 22.-Overcast, with heavy gale from S. E., causing very high tide and salt water to back up in Narrows. Lost about 300,000 young fish from this cause. Sent dispatch to this effect to Maj. Ferguson. Sent 460,000 young fish above Havre de Grace. Rain about 3 P. M., wind shifting to N. W. changing about 5.30 P. M. to East. Grass giving us great trouble, it having been broken up by heavy wind, by getting in pipes, preventing an even flow of water to cones. Placed 550,000 young fish in cylinders, as ordered, to be kept for shipment. Received dispatch in regard to departure of Machinery Barge No. 2, from Baltinore. Obtained 540,0(0) eggs at night.

May 23.- Showery, with light winds during day. Machinery Barge No. 2 arrived about 5.30 P. M., and was moored sately alongside other barges. Obtained about $560,(900$ eggs at night. Informed Maj. Ferguson of arrival of barge by telegraph.

May 24.-Clear and warm. All hands at work early arranging barges. Sent Launch No. 2 to Havre de Grace at 9 A. M. for Maj. Ferguson, who arrived about $12 \mathrm{M}$., bringing $\mathrm{Mr}$. Rettig, a machinist, with him, to arrange machinery on Barge No. 2. Maj. Ferguson returned at 5 P. M., leaving Mr. Rettig. Sent men to gather spawn. They returned, bringing only 100,000 eggs, and stated that the giller's would not allow them to examine their fish unless they received for. each for spawning tish. No doubt they would have obtained a very large number of egas had they been allowed to ex- 
amine tish, as a great many ripe ones were reported.

May 25.-Clear and warm. Sent dispatch to Maj. Ferguson in regard to action of gillers. Mr. Rettig left at $7 \mathrm{P}$. M. having arranged machinery of Barge No. 2. Sent to Harre de Grace for shipment, 1,750,00() young fish. which were turned orer to Mr. Sinmons. Also sent three men to assist in taking care of them. 'There were 41 cans and 5 large cylinders. Received dispatch from Maj. Ferguson in regard to gillers, offering as an inducement to allow us to examine their fish, the following prizes: $\$ 50.00$ to giller furnishing greatest number of ripe fish. $\$ 25.00$ to second and $\$ 10.00$ to third. Also ordered A. Hamlen and Jones to Washton. This left me with a small force mostly new men and they only obtained 240.000 eggs at night.

May 26.-Clear and warm. Sent A. Hamlin and Jones to Washington, furnishing them with transportation order. Transferred crnes and fish to new Machinery Barge. Obtained only 80.000 eggs at night. Yen reported great scarcity of male fish.

May 27.-Clear and very warm. Had men at work cleaning up and arranging Barge No. 2.Turned 1,070,000 yorng fish in Narrows, not having cans in which to transport them above Havre de Grace. Obtained only 100,000 eggs from same cause as before stated. Do not think the prize system will work well, as the gillers seem averse to allowing spawn \&c. taken, to be used save in their own boats.

May 28.-Clear and warm. Strong wind from S. E. about 1, P. M. Simmons returned with cans, \&c. 
Only obtained 40,000 eggs at night.

May 29.-Cool and clear. Sent 100,000 young fish to be placed in Bush River. Launch returned about 12 bringing Capt. Tanner and Machinest Barry. Capt. Tanner spent day in examining arrangement of cones and working of outside cylinders. He left in 4 P. M. train. Troubled again with backing up of salt water and requested him to so inform Maj. Ferguson. Ordered tug to come down early in morning to move us. Received 4 reflecting lamps for Barge No. 2. Obtained 220,000. eggs at night.

May 30.-Cloudy and damp. All hands taking up anchors preparatory to moving above Havre de Grace. Got under. way in tow of tug about 9.30 A. M. and anclored above Havre de Grace off Watson's Island in abont 30 feet water at 12.30 P. M. Heavy S. W. wind all day. Sent men down to gather eggs at night and obtained 80.000. Rain and wind prevented gillers from going out.

May 31.-Clear and strong wind from N. W. Received 10 transportation orders, and dispatch ordering Simmons to Washington with all transportation cans on hand. Accompanied men down to gather eggs and returned with 500.000 at 11 P. M.

June .1.-Clear and pleasant. Received boxes containing jars \&c. from Hatching house, Druid Hill Park. One of Winan and two of Ferguson jars broken. Prof. Ryder engaged most of day arranging for retardation of the hatching of shad eggs. Heavy storm with rain from $\mathrm{N}$. W. about 7 P. M. Sent men to Battery whence they returned at 10.30 P. M. with 
180,0(0) egas. The storm prevented gillers from casting. Great scarcity of mate fish rejorted.

June 2.-Cloudy and light rain during the forenoon. Engaged Collins and Myrte from Harre de Grace to assist in taking spawn as directed by Maj. Ferguson. Sent men out at night and obtained 340.00() egges. Saroity of male fish prevented their doing better.

June 3.-Clear and pleasant. Machinist Barry busily engaged arranging machinery and engine. Went to Pt. Deposit accompanied by Prof. Ryder to examine sperimen of fish reported raught there. It proved to be an Albino cat fish which we brought with us. Heary squall with rain abont 6.30 P. M. Very few gillers ventured out. so we only ohtained 60,000 eggs.

June 4.-Clear and pleasant. Engine and machinery started ahont 5 P. M. working more regularly. Sent Prof. Baird the Albino cat fish by express by 9.5: train. Sent M. Gleason with $30(0,000)$ young tish on $12 \mathrm{M}$. train to Bush River. He retumed at $4 \mathrm{P}$. M. Men obtained 680.00() eggs at night. They were placed in cylinder at $11 \mathrm{P}$. M.

June 5.-Orereast with heary wind from S. Prof. Holman, a guest of Prof. Ryder's, arrived from Philadelphia. Had to stop engine on account of heary sea, which interfered with cylinders. Prof's. Hohman and Ryder accompanied spawn taker's at night. Only obtained 160,000 eggs, the heary sea running off the battery, preventing gillers from casting. Placed 485,000 young fish in river.

June 6.-Clear and pleasant. Machinery \&c., moving smoothly. Prof. Holman left at 6 P. M. 
Obtained 440,0(*) eggs which were placed in cylinders at $10.30 \mathrm{P}$. M.

June 7.-Clear and rery warm. Cylinder's working nicely and fish hatching rapidly. Placed 55,(00) young fish overboard. Obtained 640,000 eggs at night, of which I placed 25,000 in Wright's boxes to hatch.

June 8.-Clear and pleasant. Gave Machinist Barry permission to go to Wilmington. Del., on business. Placed 650,(0)(y) young fish orerboard. Eggs hatching out a greater proportion in cylinders than in cones. Obtained 220,000 eggs at night.

June 9.-Overcast and cool. Went to Harre de Grace with Prof. Rycler to weigh roe of shad, and found by calculation it contained at least 225,000 eggs. Maj. Ferguson, Mr. Stone of Cal., and Mr. Herbert Gill, arrived on $11.30 \mathrm{~A}$. M. train. Mr. Gill engaged in settling accounts during day and leit at 5.4.) P. M., Maj. Ferguson and $\mathrm{Mr}$. Stome learing at $2.12 \mathrm{P}$. M. Obtained about 220,000 eggs at night. Large falling off in catch of fish reported.

June 10.-Raining. Capt. Tanner arrived at $12 \mathrm{M}$. spent morning in examining construction of boats suitable for spawn taking. He left on 4.30 P.M. train for Wilmington. Del. Obtained 380,000 eggs at night.

June 11.-Clear and pleasant. Discharged Conrtney and Hardy at their own request. Received dispatch to send fish to Baltimore. It was afterwardscountermanded and one received to send 1,000,000 fish t6) Perryville, for shipment to Maine on 12th. The time for gilling having expired by law on the loth, and having received orders not to send ont after that date, obtained no more eggs. Very few men gilling and few fish taken. 


\section{XXXY}

June 12. - Clear and intensely warm. 'Thermometer at 9 A. M. 92\%. Had all hands hard at work 1 P. M. taking up young fish for shipment. Terrific storm about $2.15 \mathrm{P}$. M. from N.W. with heary rain, striking us with full force, causing us to break adrift and be driven ashore on bank of rirer. Lost 500,000 young fish overboard and 380,000 eggs nearly hatched; also, three anchors, chains, \&c. Sncceeded in getting $900,(0)(0)$ young fish safely to Perryville before the gale. Informed Maj. Ferguson by telegraph the result of the storm. Cleared away about 6 P. If and had all hands at work hauling barges off. This we succeeded in safely doing at high-water. 11.30 P. M., and moored them safely alongside "Cochran"s Ice House "harf."

June 13.-Clear and rery warm. spent day fixing up. Had heary squall and rain from N. W., about + P. M.

June 14.-Cool and pleasant. Maj. Ferguson arrived at 11.30 A. M. and returned at 1.30 P. M. Cast off from Ice Honse wharf and anchored in stream, as directed, at 6 P. M. Forwarded iron pieces, \&c., to Maj. Ferguson, by express. Prof, Ryder left for Washington at 2 P. M.

June 15.--Raining. Discharged Captains Poplin and Farr, machinist Barry. engineer's Troodland and Jeffries. and spawn-taker's Freedy, Fletcher, Bailey, Mittendorfï and Myrtle. whose accounts I forwarded Mr. Gill. Sent by express to Perry \& Jones, cylinder with bottom \&c., as ordered by Maj. Ferguson. Engaged most of day taking inventory of barge No. 2, and sent all bed linen \&c., to be washed.

June 16.- (lear and pleasant. Light shower during afternoon. Sent hoisting engine to $\mathrm{W}$ ashing- 
ton, as ordered by dispatch. 'T'ook inventory of barge No. 1, and had paint \&c.. on sleeping barge all washed.

June 17.-Clear and pleasant. Sent Launch up and obtained $\frac{1}{8}$ cord wood. The day was spent in cleaning up \&r. Washing returned at night. June 18. - Clear and pleasant. Received tive large boxes from Washington to store blankets \&c., which we did, leaving full list inside.

June 19.-Clearand pleasant. Day spent inclearing up.

There was nothing done afterwards but the sending of two of barges to Baltimore, in tow of 'Taylor's tug; and the remaining two left at wharf at Harve de Grace with Launch, in charge of M. Gleason, machinist Flynn, and fireman Spillman, of $\mathrm{L}$. S. $\mathrm{N}$. 


\section{XXXYII}

MI). ('OHMISSION OF

RECORD OF OBSERVATIONS made at Spesutie Narrows, on the U.

\begin{tabular}{|c|c|c|c|c|c|c|c|c|c|c|c|c|c|c|c|}
\hline DATE & & & & & TH: & IIYEL & BATEV & REOI & - & & & 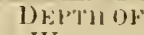 & & WIND. & \\
\hline $\begin{array}{l}\equiv \\
\equiv \\
\equiv \\
z \\
= \\
\dot{z}\end{array}$ & $\begin{array}{l}\equiv \\
\vdots \\
\equiv \\
\vdots \\
\equiv \\
\equiv\end{array}$ & & 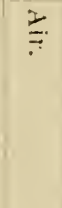 & 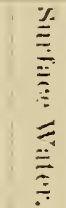 & $\begin{array}{l}\bar{\vdots} \\
\vdots \\
\vdots\end{array}$ & $\bar{z}$ & 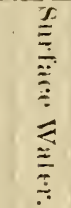 & $\stackrel{\Xi}{\Xi}$ & $\varlimsup_{1}$ & 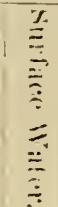 & 三 & 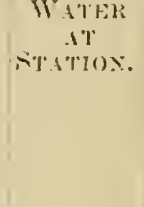 & $\begin{array}{l}\Xi \\
\vdots \\
\vdots \\
\vdots\end{array}$ & 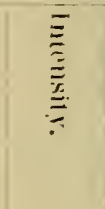 & 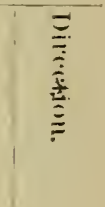 \\
\hline & & & & $7: 111$ & & & 12111 & & & $i 1$. & 11. & & & a. 111. & $1: 2$ \\
\hline Monular & & $\therefore$ & & & & & & & & & & & IV. & Stro!1\% & S. 11 \\
\hline Tuestily & & \pm & (i) & (ii.) & (i..) & -2 & iit; & $i i i$ & $\because 1$ & iiti & $1: 3$ & 1.516 .2511 . & $\therefore 11$. & $\because$ & $\ddot{r}$ \\
\hline Wedluesilay & & i & (\%2 & iji, & $6: 3$ & $7: 3$ & iiti & 6:. & $\because \because 4$ & 6.5 & ij.j. & & ‥ E. & $\therefore$ & E. \\
\hline 'Thurstay & & i; & (i1 & lit 1 & (i.j) & -1 & $i i_{i}$ & $i_{i}^{-}$ & 724 & $\mathrm{Ai}_{i}$ & $1 ; \bar{i}$ & & $\therefore 11$. & $\cdots$ & X. 11. \\
\hline Findity & & ๘ & $b \div x^{3}=$ & (ii.) & (i.) & !! & (i) & ii & (3) & tii & $1 ; \bar{i}$ & & S. E. & Gentle & S. E. \\
\hline Satmilas & & y & $13: i$ & 6.5 & iFit: & is & $\operatorname{lin} 1 /=$ & $B_{i}$ & $\therefore$ & $\overline{: 11}$ & ii!i & & & 6 & $11 \%$ \\
\hline Sumblay & & $\because 1$ & $19: i$ & 15 & 175 & $\because$ & [1 1 & 69 & 797 & 72 & $\because 2$ & & S. & C'ailu & ล. II \\
\hline Momlay & & 111 & is & {$\left[i_{1}, 3\right]=$} & $1 i(1)$. & 53 & $721: 2$ & $711 \because$ & 73 & (B) & 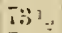 & & $\because$ & (isutle & 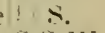 \\
\hline Truestay & & 11. & 71 & 113 & 711 & $\therefore 1$ & 施 & {$[2]^{3}$} & $i !$ & $7: 3:=$ & $7 \because 3=$ & & $\therefore W$ & $\cdots$ & S.S. II. \\
\hline Wedneshay & & 12 & itio & {$[11]^{0}=$} & (11) & $\therefore$ & 164 & 71 & $7 \because 7$ & 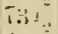 & $7 \because 3$ & & T. 11 . & St10!:4 & 5.11 \\
\hline 'Thmrsolay & & 13 & 111 & 65 & $4 i$ & (i) ? & .11 & (i9) & (b) 1 & $1 ; 9$ & is: & & & Iligl] & \\
\hline Friday & & $1+1$ & 55 & its & it & (ii:) & iii & ij. 3 & (i) 1 & iit & bit; & & & $\therefore$ & N.E. \\
\hline Satuliolay & & 15 & 52 & (it) & int & bil & tirt & titi & 631 & (i.) & lit & & & 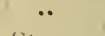 & $\therefore$ \\
\hline Sunflay & & 16 & $(i 2)$ & (i) $]=$ & (i) 1 & $72 ?$ & bit & $1 ; \vdots ;=$ & ini & liti & $6.5 ?=$ & & X. & Stlouger & S.S. IF. \\
\hline Monday & & 17 & (1) & $(i+)^{\prime}=$ & int & $\therefore$ & $4 i$ & $b: ;=$ & $\div \div$ & tiv & iis & & 11 & Gentle & Y. IV. \\
\hline Juesilay & & is & it) & 17 & siti & $\therefore \div$ & $\because 1$ & 11 & 99 & $\because$ & $\div 11$. & & $\therefore 11$. & Light & S. E. \\
\hline Wramestlaty & & $19 !$ & (i) & 137 & it $t^{3}=$ & $\because-$ & $\overline{11}$ & (i) & 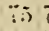 & $\because \because$ & 713 & & $\therefore E$. & $\cdots$ & ․ F. \\
\hline 'Thursulay & & 20 & 713 & 69 & 199 & $\times .5$ & - 3 & $i 1$ & $-(1)$ & 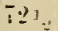 & $11:$ & & & $\cdots$ & $\because$ \\
\hline Friday & & 21 ! & $7 \because$ & 71 & 71 & S11 & $7: 3 ! \div$ & i: & 7 & 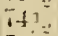 & if $\because$ & & $\therefore \mathrm{E}$ & Strollug & $\therefore$ \\
\hline Saturilay & & 22 & (1:) & -1 & bit & -1 & $73 !=$ & $7 \because ;:$ & $6 ! 1$ & 74 & $i-1$ & & $\therefore 11$. & $\cdots$ & S. 11. \\
\hline Suluclas & & 23 & 6. & $\because 2$ & 72 & it & (2) & $\because 23:$ & 69 & $733 \therefore$ & $\therefore:$ & & E. & Lighli & $\therefore E$ \\
\hline Molliar & & 24 & 71 & 73 & $7: 3$ & 8.5 & 75 & i: & 91) & 7.5 & $\because \pi$ & & I. E. & $\therefore$ & $\therefore$ \\
\hline Tnestidy & & 251 & iti & $7 \frac{1}{x}$ & it & $9 i$ & $\because$ & $70 \mathrm{i}:$ & 527 & 79 & i9 & & $\therefore 11$. & $\cdots$ & * \\
\hline Weslnt'silat & & $2 i i$ & $71 ;$ & $\because \because 1$ & C & 9 & $\therefore 2$ & $79+$ & $65:$ & 52 & $\rightarrow 11$. & & $\cdot \cdot$ & $\because$ & S. 11 . \\
\hline 'Thursday & & 2 & s:3 & So) & $\div 9 \div$ & 4 & 30 & 793 & $9-7=$ & 52 & $511 \%$ & & $\because$ & $\because$ & 6 \\
\hline Fridas & & 25 & $7 \varphi$ & 79 & 79 & $\therefore$ & पी 1 & $-11 \div$ & $\because \because$ & S11 & 791 & & 11. & $\cdots$ & ऽ. E. \\
\hline Sâmlolat & & 29 & lis & 76 & $i t i$ & 5.5 & i) & i) & 71 & $\because$ & $\because 7$ & & ․ F. & Stlorlugr & E. \\
\hline Sunclay & & $\because ; 0)$ & $7 \vdots$ & ili & ili & (1) & $\therefore$ & is & is 7 & iti & $i 6$ & $3.510+11 \mathrm{ft}$. & S. E. & $\cdots$ & S. II. \\
\hline $\mathrm{Mn}$ & & 31 & $7:$ & 76 & $i t i$ & $-\vdots$ & $\bar{\vdots}$ & $71 ;$ & $>0$ & 77 & $\because$ & & X. 11 . & $\because$ & X. Wr. \\
\hline Tuesrlar & Jute & 1 & $\because 3$ & 73 & $\left.i^{3}\right]$ & 191 & $\because$ & $\because 7$ & it & 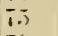 & it & & $\therefore \mathrm{F}$ & Ligrlit & S. E. \\
\hline Werinestlas & & 2 & 5 & (7) & 74 & , si & it & $7 \div$ & ii & 72 & 72 & & S. 11 . & Stroug & N. E. \\
\hline Thursilay & & 3 & tis & $i \div$ & 71,6 & $3 i j$ & (i)! & (i) & $\pi$ & iI & 11 & & •. & Light & I. II. \\
\hline Frinlay & & 4 & 72 & -11 & 311 & 4 & $\because 1$ & $i 1$ & 80 & 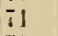 & $i$ & & $\because$ & is & S. E. \\
\hline Satniday & & 5 & 69 & {$[4]$} & 24 & $\because$ & 7.5 & $7+4$ & 74 & 72 & $71]$ & & s. E. & $\because$ & S. E. \\
\hline Sunclay & & ii & 78 & 7.1 & $7: 31$ & is & 74 & $\left\lceil B^{3}=\right.$ & 76 & 7.2 & -113 & s.j tofloft. & $\therefore$ ii. & strutug & $\therefore 11$. \\
\hline Mionday & & $\because$ & 84 & it & $i+1$ & 39 & $\overline{1}$ & 70 & 79 & $6 \pi$ & 7.5 & & 5.11 & Gelltle & N. II. \\
\hline Tnesilay & & 8 & ii) & 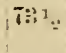 & 73 & 37 & $\begin{array}{l}7 !) \\
3 \mathrm{pm}\end{array}$ & $\because T$ & 7.5 & is & iii & & S. E. & Ligrht & S. E. \\
\hline Wednesilay & & !). & (i) & $\pi 6$ & $i l i$ & :! & $\because$ & $i+i$ & 71 & $\pi$ & iti & & X. E. & Light & S. E. \\
\hline 'Thurkiay & & 111 & $6 \%$ & (ii) & $\pi 5$ & 7.2 & it & 71 & $1 \% 9$ & it & $i 3$ & & S. E. & $\because$ & 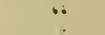 \\
\hline Frelay & & 11 & iis & $\because 2$ & i1:: & 71 & $\because 2$ & $71\}:=$ & SII & 73 & $\because 2$ & & $\because$ & $\cdots$ & $\because$ \\
\hline Sainrilay & & 12 & $\therefore 2$ & it & $73^{1}=$ & 92 & 79 & $7 \%$ & 52 & 76 & iti & & N. 11. & $\because$ & S. W. \\
\hline Sunrlas & & $1: 3$ & $\mathrm{~S}: 3$ & $\pi$ & 71 & 92 & 79 & 15 & 3i) & 19 & ix & & S. 15. & - $\quad *$ & 5. 11 . \\
\hline Rlonday & & $1 f$ & 75 & -79 & 7 & $5 i$ & it: & 77 & 73 & $\pi$ & 75 & & X. $11 \%$ & Sitlon)!y & $5 . \mathrm{K}$. \\
\hline Pnesdar & & $1 . i$ & & $\pi i$ & $17: 2$ & 16.5 & 75 & 7 & 0.5 & & in & & N. E. & .t & N. \\
\hline
\end{tabular}


FISH AND FISHERIES.

S. Fish Commission Barges, from May 3d, I880, to June I5th, I880, Saunders.

\begin{tabular}{|c|c|c|c|c|c|c|c|c|c|c|}
\hline \multicolumn{3}{|c|}{ IVIND. } & \multicolumn{4}{|c|}{ CONUITION OH- } & \multicolumn{4}{|c|}{ STATE OH- } \\
\hline$\underset{\Xi}{\Xi}$ & 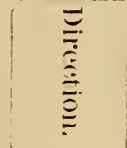 & 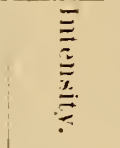 & 先 & 年 & 菊 & $\underset{\vdots}{\stackrel{亠}{*}}$ & 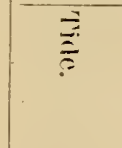 & 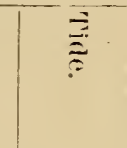 & $\equiv$ & \\
\hline rin. & $\div \mathrm{p}$. & $\mathrm{m}$. & T a. 11. & $12 \mathrm{in}$. & †p. m. & & т a. in. & $12 \mathrm{ml}$. & ( p. m. & \\
\hline $\begin{array}{l}\text { Strong } \\
\text { Gentle }\end{array}$ & S. ${ }_{66}^{11}$ & 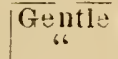 & $\underset{66}{\text { Clear }}$ & $\underset{66}{\text { Clear }}$ & ${ }_{6}^{\text {Clear }}$ & Cloudy & Eb) & $\underset{66}{E b h}$ & Flood $\alpha$ & \\
\hline 6 & S. E. & 66 & Clourly & Clondy & " & Clear & Flood & 66 & 66 & \\
\hline Strong & N. II. & 66 & Clear & Cleal & 66 & 6 & $\therefore$ & 66 & 66 & \\
\hline Gentle. & S. E. & Strong & Over'cast & 66 & 6 & 66 & 6 & 66 & 66 & \\
\hline "6 & S. 11 . & Gentle & 66 & 6 & $\therefore 6$ & - 66 & $\because$ & Slack & Eloh & \\
\hline Strollg & 66 & 66 & 66 & 66 & 6 & 66 & 6 & Flood & 66 & \\
\hline 66 & S. S. II. & Strong & $\because$ & 66 & 66 & 66 & Slalkik & 66 & 6 & \\
\hline Gale & 11. & Gentle & 66 & Overcuast & $\begin{array}{l}66 \\
66\end{array}$ & $\because 6$ & Ehl & 66 & 66 & \\
\hline High & N.". & $\begin{array}{l}\text { Gale } \\
\text { Higll }\end{array}$ & Clear & Clear & 66 & Yindo & & 66 & 66 & b \\
\hline Strong & N. E. & High & $i 6$ & 6 & 6 & $\operatorname{Mnd}_{6}$ & $\begin{array}{l}\because 6 \\
\because 6\end{array}$ & 66 & $\begin{array}{l}\therefore 6 \\
.6\end{array}$ & \\
\hline 6 & IV. & Gentre & .6 & 6 & 66 & 6 & 6 & 66 & 6 & \\
\hline 66 & S. 11. & 66 & Smoky & 6 & 6 & Clear & 6 & 66 & $\cdots$ & \\
\hline 16 & .6 & $\because 6$ & Clear & 66 & $\because 6$ & 66 & $\because 6$ & 66 & 6 & \\
\hline Light & S. E. & Light & 66 & 6 & 66 & 6 & .6 & 66 & $\therefore 6$ & \\
\hline 66 & N. E. & $\because 6$ & R:ilil & 66 & 66 & 66 & 6 & Slack & 66 & \\
\hline Stiong & S. E. & Strolleg & $\begin{array}{l}\text { Oreloist } \\
\text { Clear }\end{array}$ & $\begin{array}{l}6 \\
66\end{array}$ & $\begin{array}{l}16 \\
66\end{array}$ & $\begin{array}{l}66 \\
66\end{array}$ & Floex & & Floorl & \\
\hline 16 & E. & Livint & $\begin{array}{l}\text { Clear } \\
\text { Overcast }\end{array}$ & 6 & ، & 66 & 6 & 16 & 66 & i: \\
\hline Light & 1Y. 11 & $\therefore$ & 66 & Sltowery & 6 & 66 & 6 & 66 & 66 & \\
\hline is & S. W. & 6 & Clear & Cle & 66 & 66 & $\therefore 6$ & .6 & 66 & \\
\hline 16 & 6 & 16 & $\because 6$ & 66 & 66 & $\because 6$ & .6 & 66 & 66 & \\
\hline 6 & $\therefore 6$ & 66 & $\therefore$ & 6 & 66 & 66 & $\mathrm{E}, \mathrm{h}, \mathrm{H}$ & Floorl & Eloi, & \\
\hline 66 & S. E. & 66 & 66 & 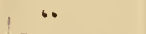 & $\therefore 6$ & 66 & $\therefore$ & 6 & $\therefore 6$ & \\
\hline Strong & N. IV. & 66 & 6: & Orel'ciast & 6 & 66 & 66 & .6 & $\because 6$ & $d$ \\
\hline Gentle & S. E. & $\therefore 6$ & $\cdots$ & $\therefore$ & Clourly- & 66 & 66 & .6 & $\therefore$ & \\
\hline 66 & S. W. & $\because$ & Clomily & Raill & liain & $\therefore$ & 66 & 6 & 16 & $\rho$ \\
\hline Stiong & S. E. & a & Clear & Cical & C]eal & 6 & 6 & 6 & $\therefore$ & \\
\hline 6 & N. & stlong & 66 & Orelcid it & Sofuall & 66 & 6 & 66 & 66 & \\
\hline 6 & N.E. & 66 & Raining & 66 & clear & Mudur & $66^{\circ}$ & 6: & 66 & \\
\hline 6 & N. II. & 66 & Cleas" & Cieal & Strol'my & 6 & 66 & Slack & 66 & \\
\hline Liglil. & N. E. & Light & 66 & "6 & Clcar & 66 & Floorl & $\mathrm{Ebb}$ & 6 & \\
\hline Strong & S. E. & High & Ovelcast & Overcist & 66 & Clear & 66 & 66 & Floot & \\
\hline High & S. IV. & Light & Clear & Clear & 16 & 66 & $\therefore 6$ & $\therefore 6$ & 6 & $f$ \\
\hline Light & X. II. & Geintle & 66 & 66 & 66 & $i 6$ & 66 & 66 & 66 & \\
\hline 66 & E. & 66 & Clear & .6 & 66 & .6 & 6. & $\therefore 6$ & 6 & \\
\hline Liglit & S. E. & cientle & Overoast & Overuast & Orercast & t) Clear & Slack & Ebl) & Flooul & \\
\hline "6 & N. W. & 6 & Rain & 66 & Rain & 66 & Flood & 6 & 66 & \\
\hline 6. & S. II. & 66 & 66 & Cieat & Clear & 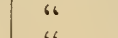 & 66 & 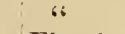 & $\mathrm{El}$ & \\
\hline 16 & 66 & 6 & Cloall' & 6 & 66 & 16 & 66 & Floo! & 66 & \\
\hline 66 & N. 11. & 6 & 66 & 66 & 66 & 66 & Ell) & 36 & 6 & $\dot{h}$ \\
\hline "6 & 66 & "6 & 66 & 66 & 66 & 66 & 6 & $\therefore$ & $\cdot 6$ & \\
\hline 8trong & N. E. & Stroulg & Ratining & Rainimg & Raining & 66 & 66 & *. & 16 & $i$ \\
\hline
\end{tabular}

a. Nothesmoncere to take temperatiace.

b. Vel'y low tirle.

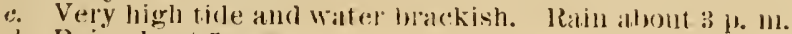

a. Raill about ì j. 111.

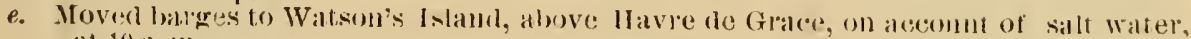
all 10 a. III.

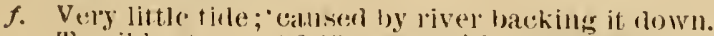

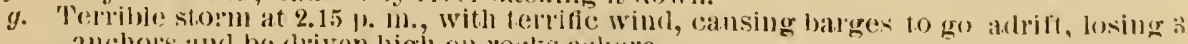
anchor:s an! be dliven ligh on pocks ashore.

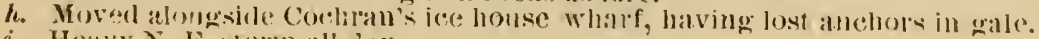

i. H('aly X. F. 40I") 


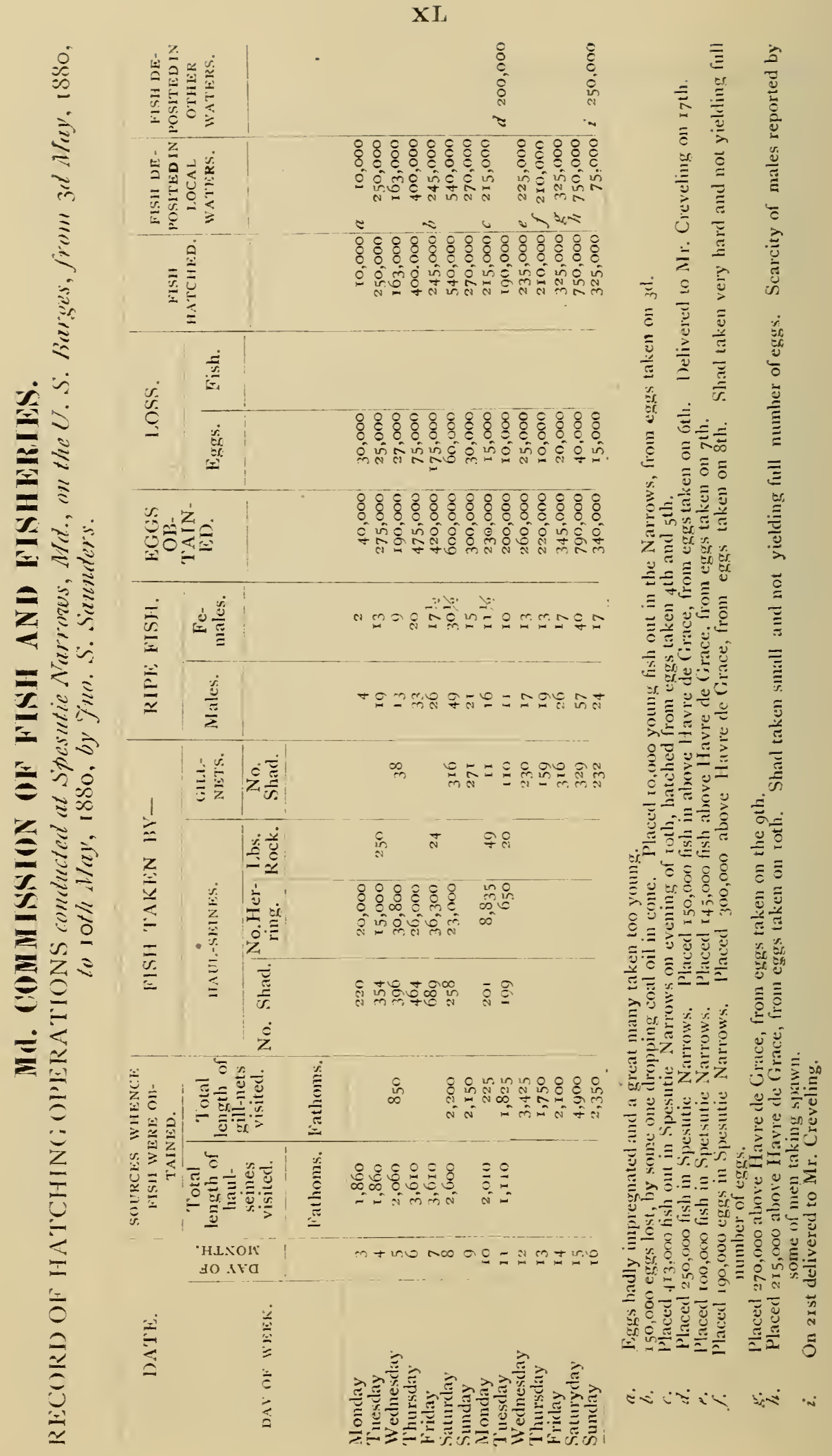




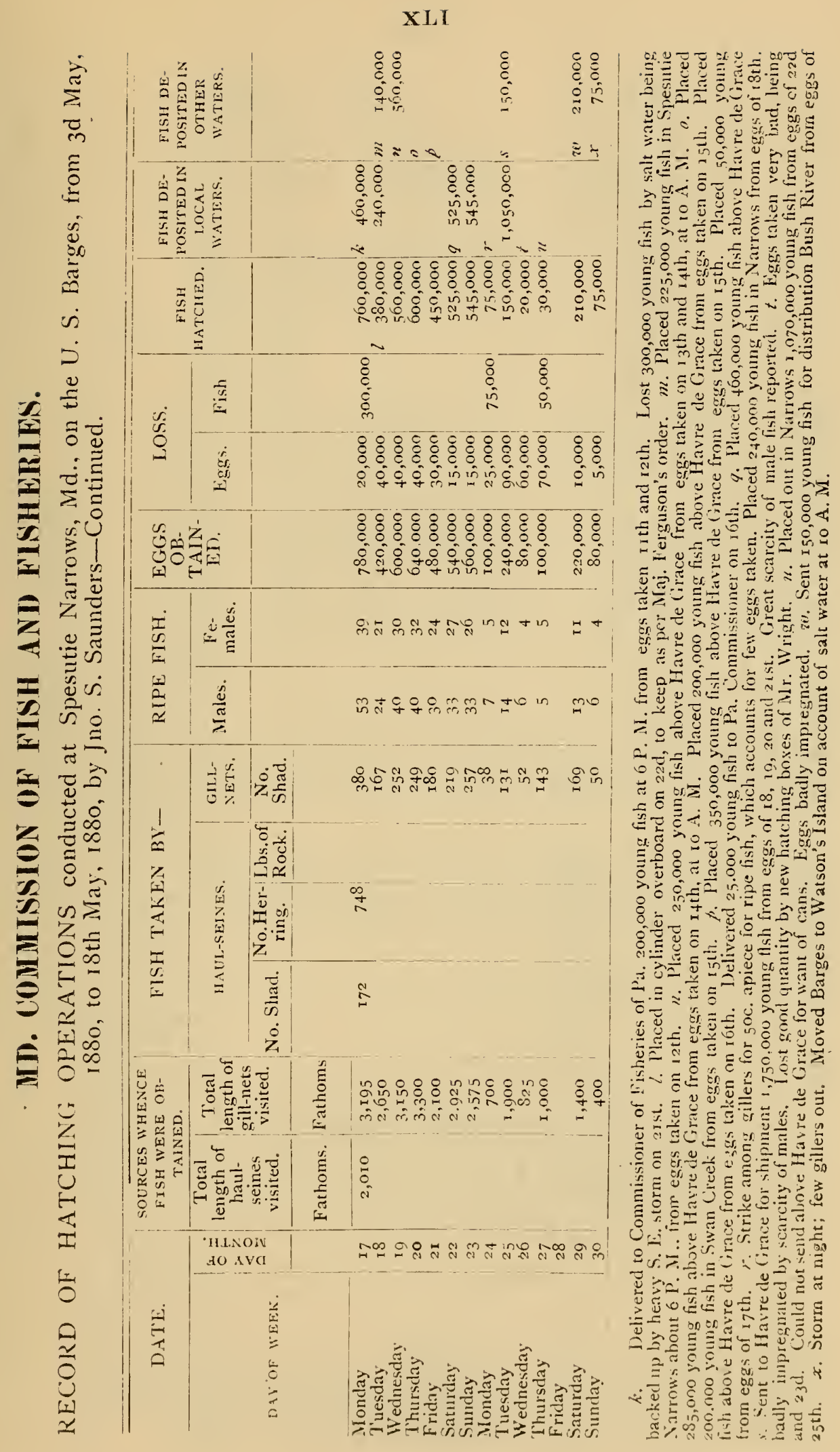




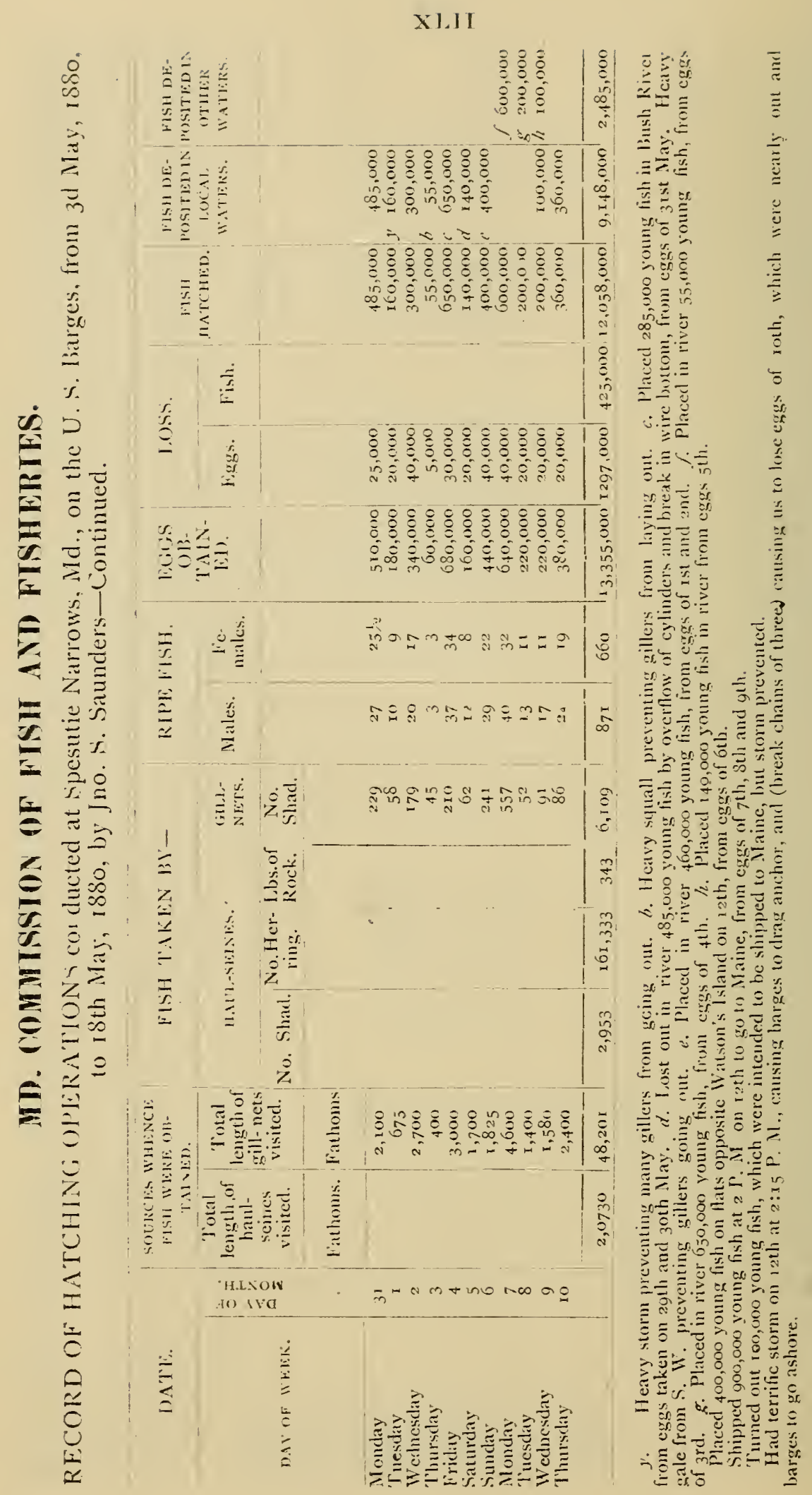




\section{XLIII}

(5)

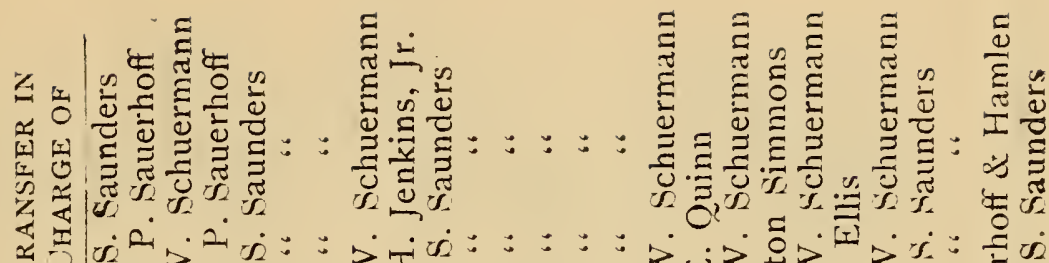

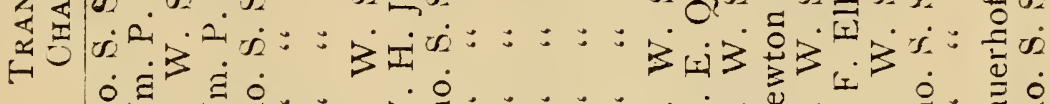

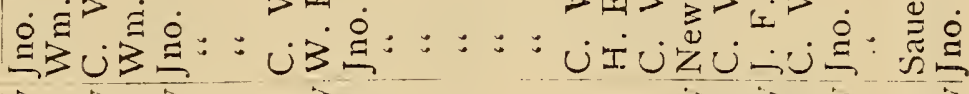

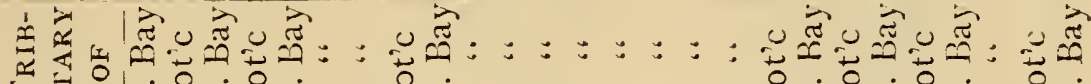

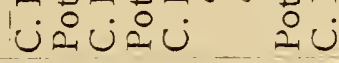

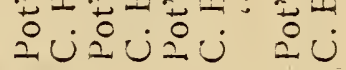
iे

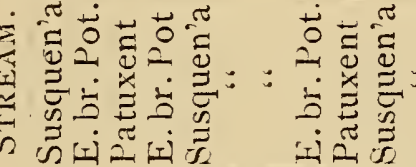
Ü: $\infty$

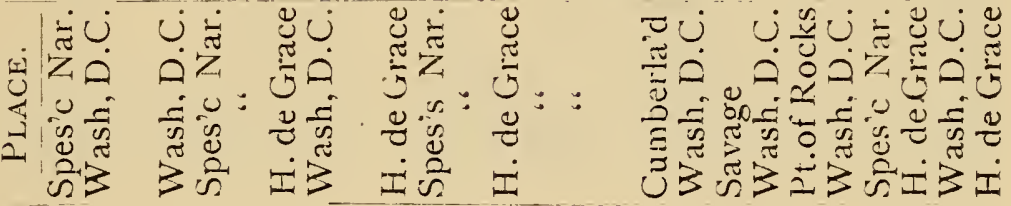
$\infty$ i)

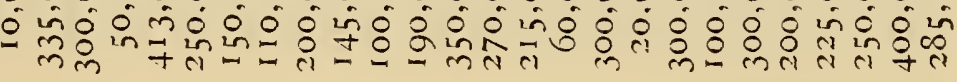

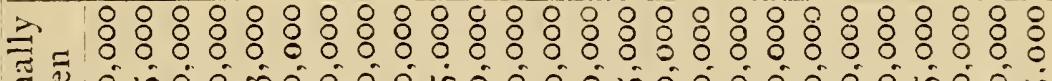
:

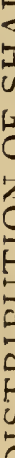

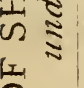

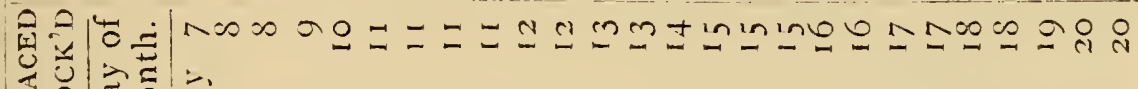
我国过 光 过 $\div \quad \frac{\pi}{0}$

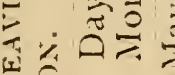

(

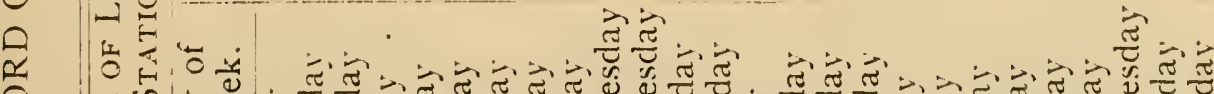

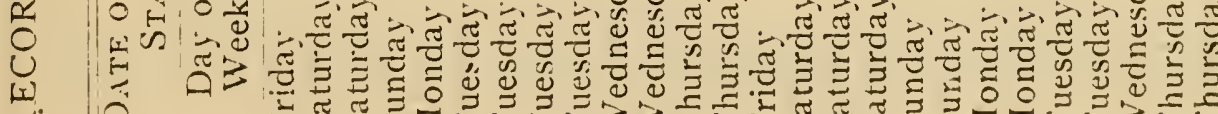
山. 


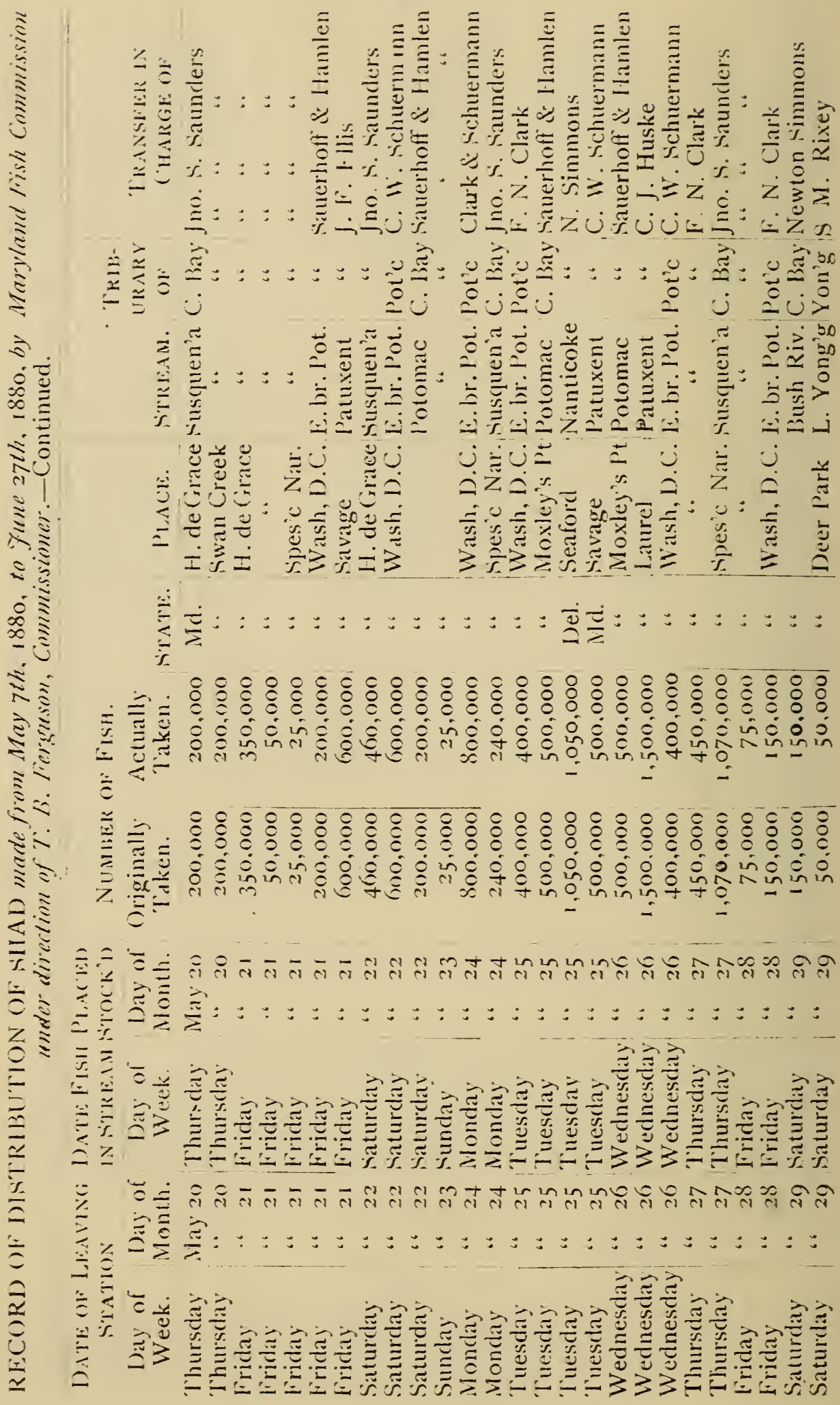




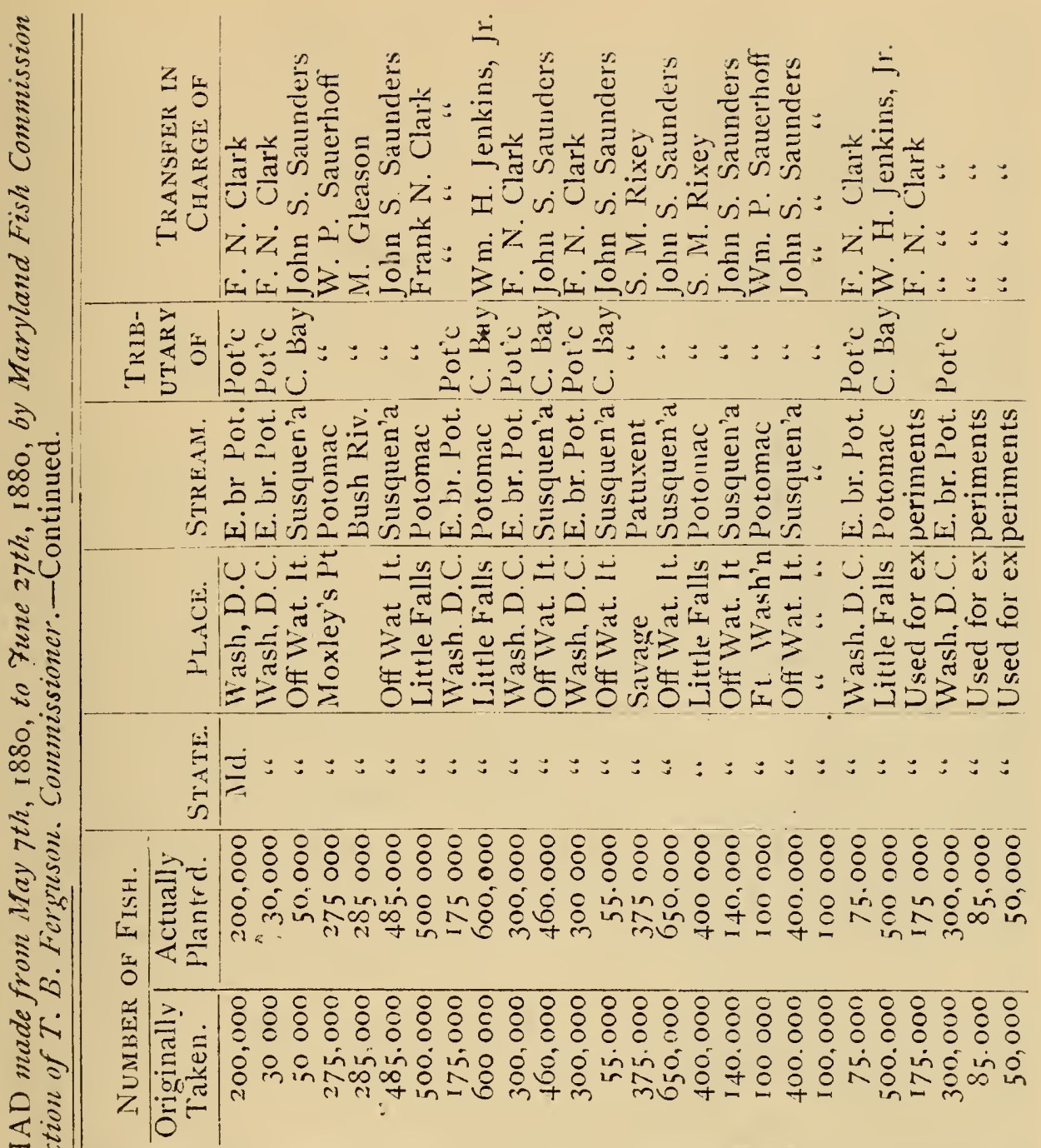

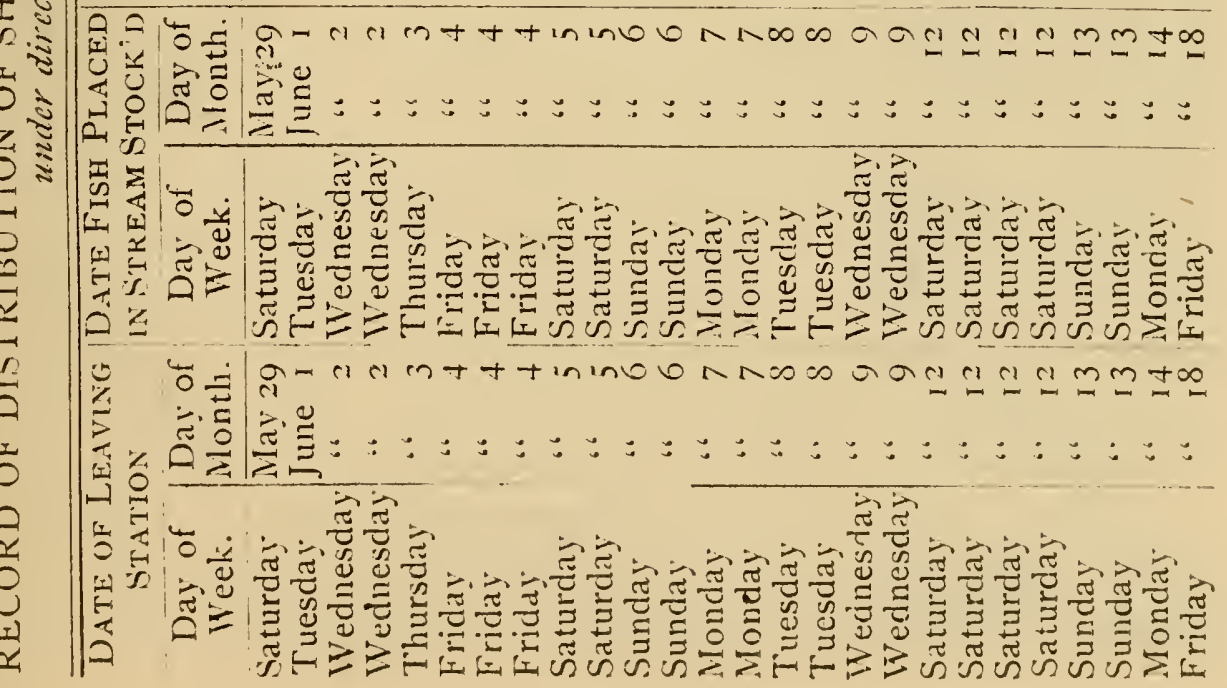


XIVI

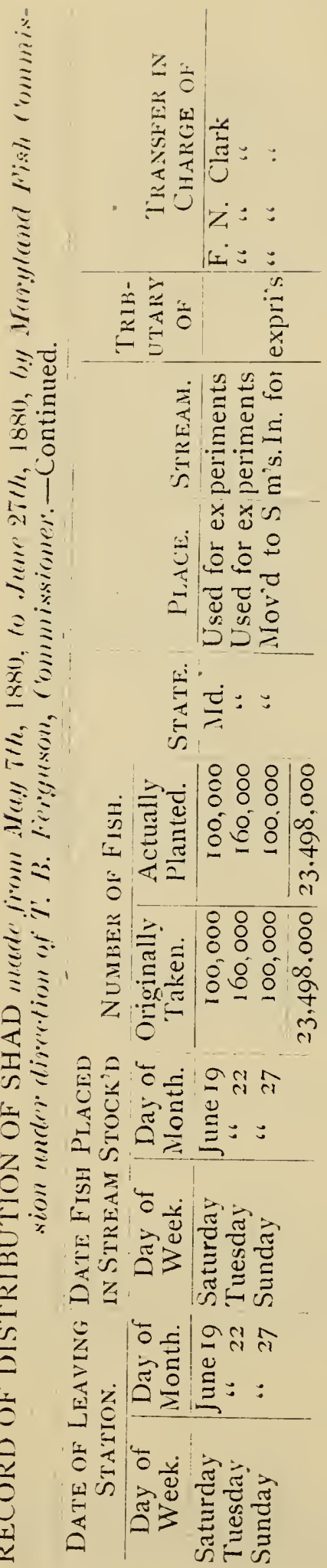


In order to insure the active co-operation of the gillnet fishermen, the U.S. Commissioner has for sereral year's generonsly paid to the giller's fifty cents for each ripe female shad delivered immediately as it was taken from the net. The fish were invariably returned to the fishermen, after the eggs had been taken, and as this operation caused no perceptible injury to the fish, the premium was a strong incentive to the co-operation of the fishermen, as it was a somre of considerable profit to them.

The Maryland Fish Commission has never consented to pay any thing for the privilege of taking spawn from captmred fish, as it has considered it but just that the fishermen shonld co-operate in a work intended for their future benefit. The $\mathrm{T}$. . . Commissioner. however, has made this contribution to the fishermen on the ground that a portion of the fish produced from these eggs were subject to be shipped to other waters: but as the forces employed by the two Commissions were operated as one and the work conducted jointly, the T. S. Commissioner has paid for all the spawn obtained from fish taken in the gill-nets.

As the work increased from year to year this premium for the ripe shad became a considerable tax on the L. S. Commissioner, and it was determined that the amount paid should be reduced to twenty-five cents for each spawning shad, and due notice was given to the gillers during the seasom of 1879 that such a reduction would be made the following season. Fven this reduced premium was a very liberal compensation for the small trouble the gillers were put to. I was, therefore, both surprised and mortified when, in the midst of the season, the fishermen refused to allow not only those employed by the $C$. s. Commission, but those also of the Maryland state Commission as well, to take eggs from their fish.

'This ronduct on the part of the tishermen might have ansed a very decided diminution in the number of fish 
turned loose in these waters, had not the U. S. Commissioner again come to onr aid and satistied the fishermen by offering them of her inducements for furnishing ripe fish.

As this "strike," as it may be designated, took place in the rery height of the season, the number of fish produced at this station was no donbt diminished by several millions.

I cannot but condemn the short-sighted policy which instigated such action on the part of our fishermen; for the results of the work-especially in this locality-have been such as to convince the most skeptical among them of our capacity to increase shad to a very marked extent, and thereby, to correspondingly increase their crop.

The number of young fish produced at the Havre de Grace station-notwithstanding the adrerse conditions of the season, and the interruption of the work from the causes above mentioned-reached 12,058,000. Of these 9,148,000 were deposited in the Maryland waters and 2,485,000 transported to other water's by the U. S. Commission.

The details of the distribution of the fish produced at this station as well as those hatched at the Navy Yard, and on the Steamer "Lookout." will be found on page 43 et seg.

It will be seen that the number deposited in Maryland water's reaches the total aggregate of $23,498,000$.

\section{HERRIAG-CYupeida.}

The commercial importance of this family, and the ease with which it can be increased in those localities where it is diminishing and re-established in streams from which it has entirely disappeared, mark it as an object not only of onl care, but close consideration and study.

On the Atlantic coast of the United States occul nine fishes belonging to the herring tribe. Four of these, the sea-herring; a fish of much economic importance on both 
sides of the Atlantic, the menhaden, another fish of extreme importance from Maine to Virginia, the threadherring and the round-herring, insignificant species of no particular value, are found solely in the sea. One, the mud-shad, or gizzard-shad, is found in brackish water, from Cape Cod to Florida, while four others lire both at sea and in the rivers, and by their peculiar habit of breeding in the rivers and feeding at sea are of the utmost importance to the river fisheries. These are the shad, the hickory-shad, or tailor-herring, and the two species of river herring. The two species of river herring have, for many years previous to 1879 , been considerer as identical, or, to speak more exactly, although fishermen have had decided opinions that there were two different kinds, this fact had not been demonstrated to the satisfaction of naturalists. Recent observations. however, have demonstrated very satisfactorily that there are two species, which, besides presenting marked and characteristic differences, are very different in their habits. One of them, the gray-back herring of Massachusetts, the branch herring of the Chesapeake waters, the Gaspereau (pomolobus vernalis) of Canada, appears to enter the rivers earlier than the other species. In the Chesapeake, the schools are said to be smaller, and they spawn higher up in the creeks. 'The other species, the glut-herring of the Chesapeake, the black-belly of Massachusetts, also known to New England fishermen by the names "saw-belly," "Kyack," and "cat-thrasher" (pomolobus astivalis), is later in its runs, and swims in larger schools near the months of the creeks. The name glut-herring, indeed is said to refer to the fact that the schools of fish are so large that they fill up or glut the mouths of small streams, as well as the markets of the vicinity, while, on the other hand, the name branchherring has reference to the fact that the other species goes up to the heads of creeks or branches. 'The glutherring seems to be more widely distribnted at sea along 
the coast of the Lnited states. and they are frequently taken in wreat quantities in the mackerel nets of the Gulf of Maine, as well as the pounds along the coast. The geographical distribution of the two species, as now understond. is quite different. Both species occur in the Chesapeake Bay and its tributaries, and both together as far north as the Bay of Fundy and perhaps the southelu part of the Gulf of saint Lawlence. The glut-herring. howerer. is found south of the Chesajeake, even as far as the Saint Iohn Rirer of Floricla, while the branch-herring. mder the nane of Gaspereatu. occurs the entire length of the (tulf of Saint Lawrence and throughout Lake Ontario. It is somewhat difficult to distinguish the two species br external characters, the best distinction being in the color of the lining of the abdomen. which is black in the glut-herring and gray in the branch-herring. The former is also distinguished by its elongated form. lower body. less elerated tins, smaller eyes and the different proportions of the bones of the hearl. It may be interesting in this connection to note the statement of two careful observers in Massachusetts, at the same time remarking that the subject is not thoromghly molerstood. and that further investigatioms nay bring to light still other speries related to those already described.

In an accomnt of the "Topograplyy and History of Wareham. Mass." (Coll. Mcess. Hist. Soc., Tol. IV., 1875,2 d series. 121 . 294-296.) is the following account of the two species of alewires. or herrings. which is interesting, since it is the first recorded instance of any discrimination between them:--

"Of the alewife there are evidently two kinds, not only in size, but habits. which annually visit the brooks, passing to the sea at Wareham. The larger, which set in some days earlier. invariably seek the Weweantic sources. These, it is said, are preferred for the present use, perhaps, because they are the earliest. The second 
less in size, and usually called 'black backs, equally true to instinct, seek the Ogawam." The "black back" here referred to is doubtless the "glut-herring". of theChesapeake region.

Col. 'Theodore Lyman, in his report as Commissioner of Fisheries for Massachusetts for the year ending Jan. 1, 1869, gives the following results of observations in various rivers of Massachusetts: "The netters recognize several sorts and several runs of alewives. The river herring is a large variety, not much esteemed, and supposed to spawn in tidal water. These are always most numerous in streams that have bad fishways; because, when once they have spawned betow a dam, the progeny are not inclined to go farther. and lie in tidal waters. Large shoals of these "sulkers" may be seen at Squawbetty, on 'Taunton Great River, or at the foot of the dam, on Mystic Pond. 'Then there are the graybacks and the black bellies, which have all the marks of a distinct species.

The black-bellies appear later in the season than the gray-backs, and though smaller are, by reason of their fatness, more esteened."

Whenever the opportunity has occurred $P$ have caused the spawn of the herring to be taken, and have tried several experiments in order to secure the best methods for propagating them, and have snceedled in hatching many hundred thousand, which have been returned to our waters. But for reasons stated in my previous Reports, no special hatching station has been established for the propagation of this fish, but this is in the program of the future.

Figures of the several speries of this family are given in order that their peculiarities of form may be carefully studied, for it is most advisable that those employed in the work of tish culture who undertake the propagation of the herring should be able to distinguish especially between the glut-hering (pomolobus astinalis) and the 
branch-herring (1). vernolis): for if the opportunities of propagating the two be equal the former should most certainly be selected as the more raluable rariety.

The difference in the spawning labits of these two species has no donbt contributed rery materially to the disappearance of the glut-herring and the continued abundance of the branch-herring; the latter seeking more isolated localities. where they are less disturbed by the fishermen. than the former.

Although the catch of herring during the last season was unusually large, yet, unfortunately, it consisted principally of the branch-herring or the less raluable variety.

Col. McDonald reports that "on the Neuse the catch of hranch-herring (p. cernalis), or wall-eyed, as it is called by the fishermen on that river, was unusually large: sometimes the catch of a drag-net was almost wholly of this species. 'The run of glut-herring was very suall. On the Albemarle the same condition of things existed. the large proportion being of the vernalis and males, being moch smaller than the glut-herring.

On the Rapjahannock the only considerable run of herring was the rernalis. These were largely male, and very small, requiring about 1100 to the barrel."

"On the susquehanna there was a herring ghut from the 1st to the 10th of May. These also were the vernalis. mostly males, and very small, as on the Rappahannock."

Hatchise House.

The fish hatched during the year $18 \% 9$ had all been distributed by the 1st of Jannary, 1880, with the exception of twelve thousand seren hundred $(12,700)$ California salmon, and eight hundred and serenty-five (875) young carp. A few Penobscot salmon. land-locked salmon, and brook-trout. were left in the brick ponds adjacent to the hatching-house.

The water supplying these ponds is mainly receired from the high-surface reservoin located on the hill to the 
west of the hatching-house, where it is exposed to the action of the sun and atmosphere and reaches a very high temperature during the heated term.

Hitherto we had found it impracticable to keep the salmonida in these small ponds except in comparatively cool summers. I determined, however, to make another effort to keep over the fish referred to, but am now satisfied that these ponds can be better ntilized for the rearing of other varieties which do not require such cold water. Alnıst all of the fish reserved for this experiment died during the summer.

$$
\text { SALMON-Salmo salar. }
$$

There were also on hand at the hatching-house sixty thousand eggs of the Penobseot salmon, which commenced to hatch on the 10th of the month, the hatching being completed by the 15th of February, when all the young fish were free from the egg. As this variety had been so successfully introduced into the Delaware River, and a few adults had been taken in the Susquehanna River on their return from the ocean, I deemed it advisable to secure as many eggs as possible for the principal waters of Maryland, and the L. S. Commissioner generously furnished us with the sixty thousand above nentioned, for the waters of the Susquehamma and the Potomac, as it was thought best to put all the fish into the tributaries of these two streams. It was arranged with the Commissioners of Pennsylvania, therefore, that I should hatch at Druid Hill Park the fish intended for the Susquehamma River, and that they shonld be transported to the headquarters of the susquehamna by that commission and deposited in the tribntaries of that stream. In accordance with this aramgement, on the 23rd of March I delivered to Mr. I. P. Creveling, the agent of the Pennsylvania Commission, twenty-thee thomsand of these fish, being the yield of one-half of the egors received, to be disposed of as above indicated. I approved of this amangment, as I was satisfied that the 
upper water's of the Susquehanna could be more readily reached through the aid of the Pennsylvania Commissioners, who were familiar with the localities best suited for the salmon during their stay in the river, and that by placing them as high up the stream as was possible their chances of existence would be rery much increased. The sources of the Potonac River and of its tributaries within the State were easier of access. and the distribution of the tish intended for that river was efferted under the auspices of the Maryand Commission.

The fish prodilced from the abore-mentioned (io).0(0) salmon eggs were deposited as follows:--

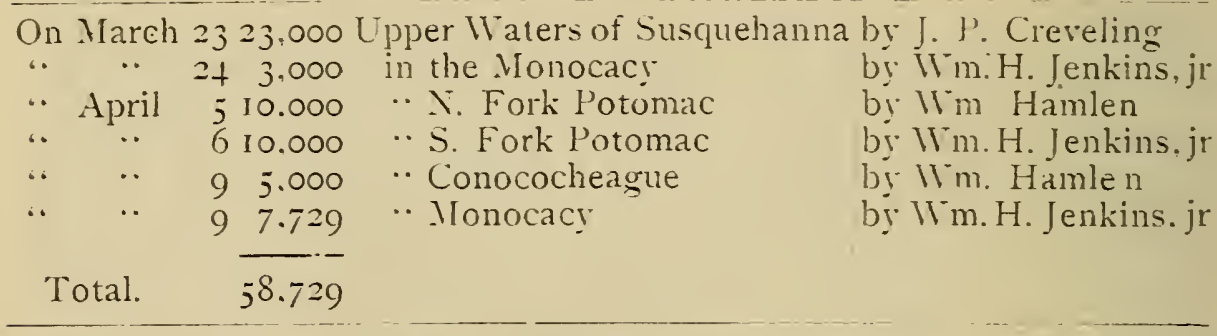

LAND-LOCKED SALMON.

On the 22nd of January a gift of twenty-fire thousand $(25,000)$ eggs of the land-locked salmon was receired from the L. S. Commissioner. being part of a lot collected by him from Grand Lake stream. Maine. As this variety of the salmon family has lost its propensity for migrating to the ocean, its introduction into the streams and ponds of the State has been attempted. with special regard for those portions of the state which are drained by the tributaries of the Ohio River. The experiments tried with this fish in the ponds at Drnid Hill Park would indicate that it is better adapted to withstanding extremes of heat than is any other variety of the same family. Is it attains a larger size and grows more rapidly than the brook-trout its domestication in trout streams is much to be desired.

The disposition made of the fish produced from this lot of egas is indicated in the accompanying table:- 


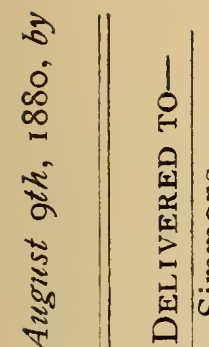
|

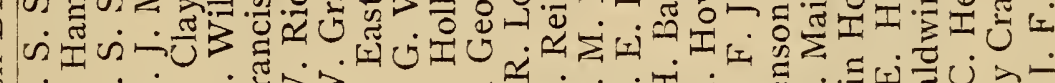

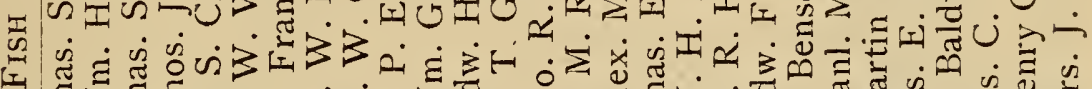

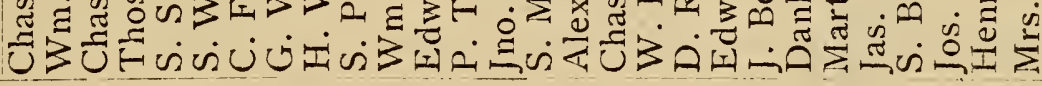
1

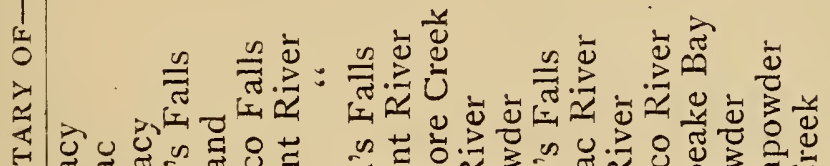

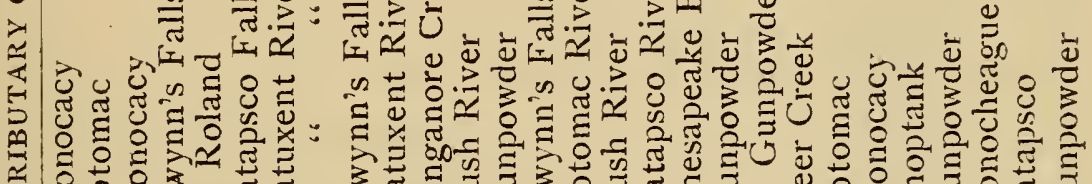

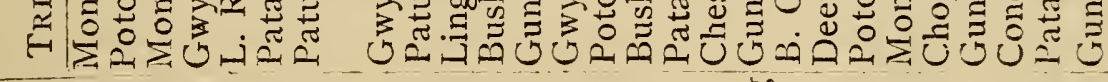

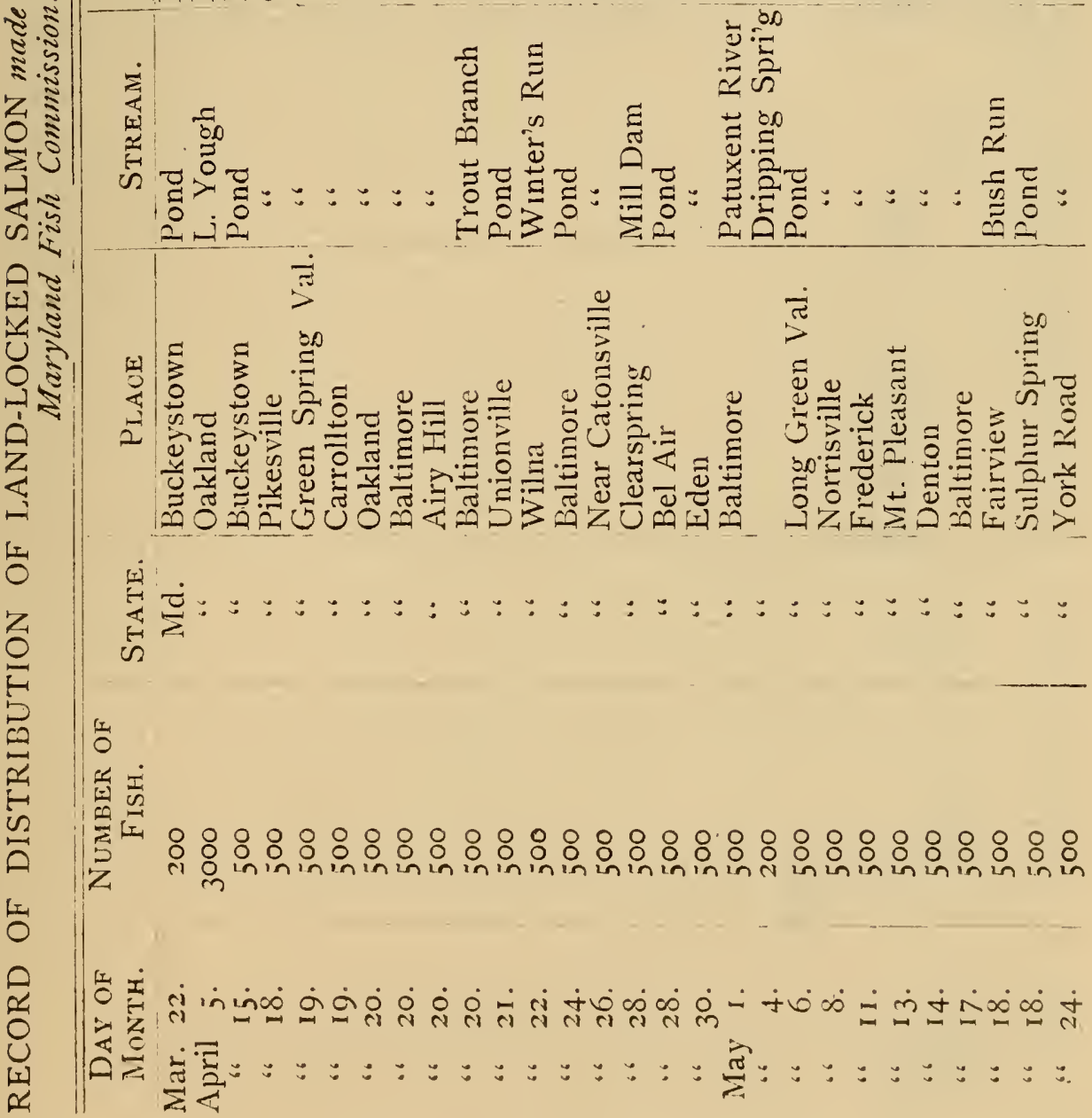




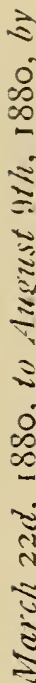

\begin{tabular}{l|l}
0 & 1 \\
0 & 0
\end{tabular}

$\cong \quad$ 高

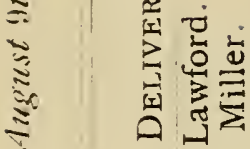

$\therefore \quad$ 密

i

i 11

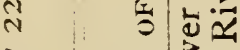

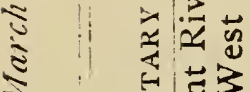

空

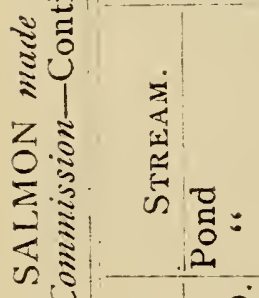

$0 \div \quad 0$

洨

บे

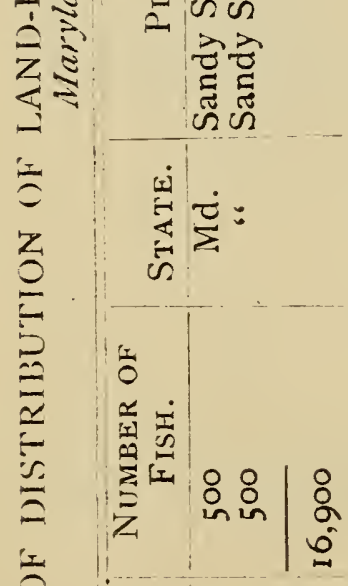

จ

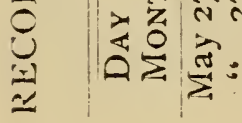


California Salmon-Oneorhynchus quinnat.

The experiments of hatching the eggs of the California salmon in floating boxes were renewed in the north branch of the Potomac at the point near its source, which had been selected the preceeding fall, and was attended with equally successful results.

About 200,000 eggs were obtained from the U. S. Commissioner of Fish and Fisheries. These were landed at Oakland and transported thence in a wagon to the point indicated, where they were hatched and the young fish protected until the sac was sufficiently absorbed, when they were liberated in the Potomac between the hatching station and Fort Pendlêton.

An account of the work at this place in detail will be found in the accompanying table:- 
I,IIII

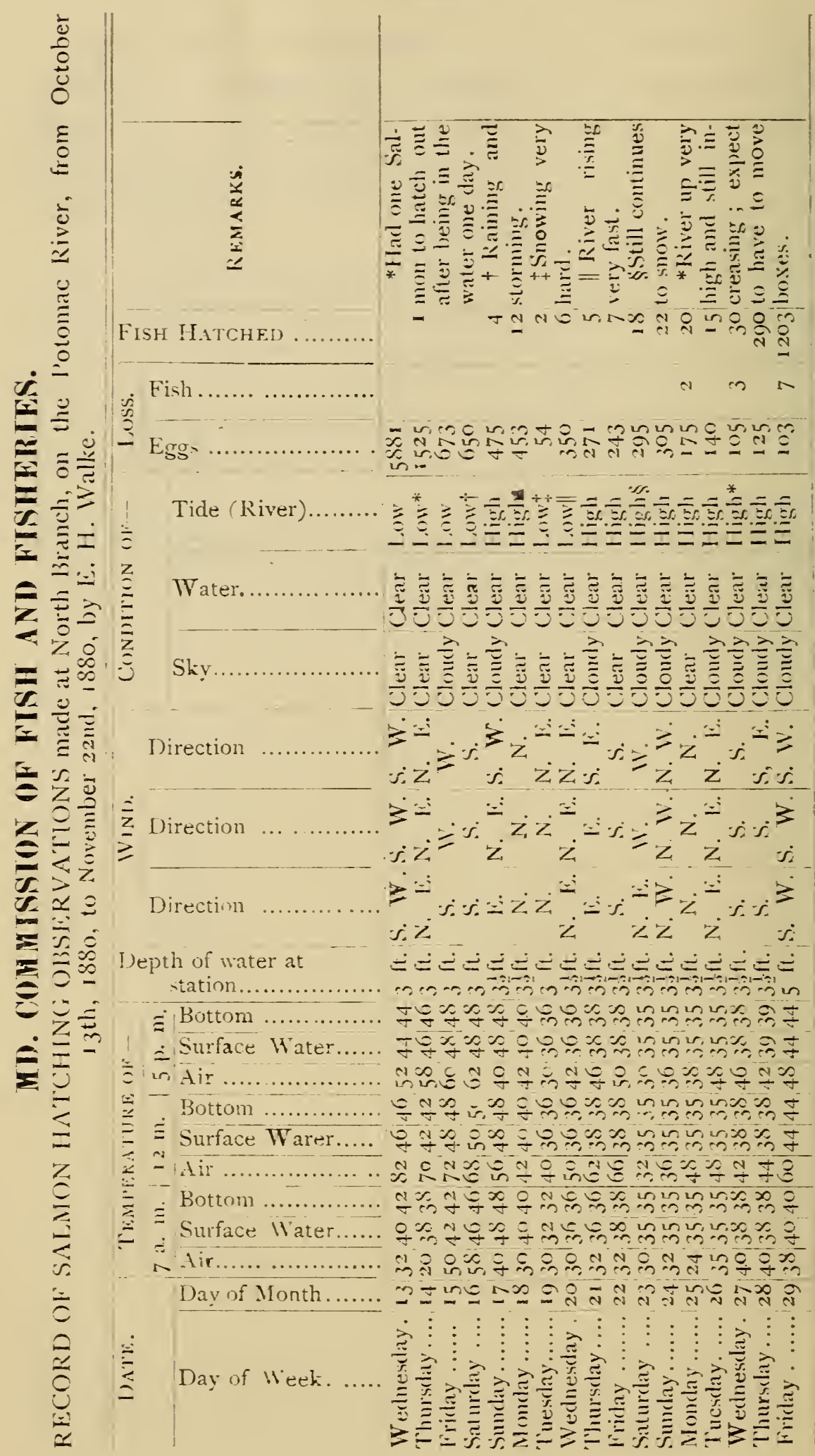




\section{LIX}
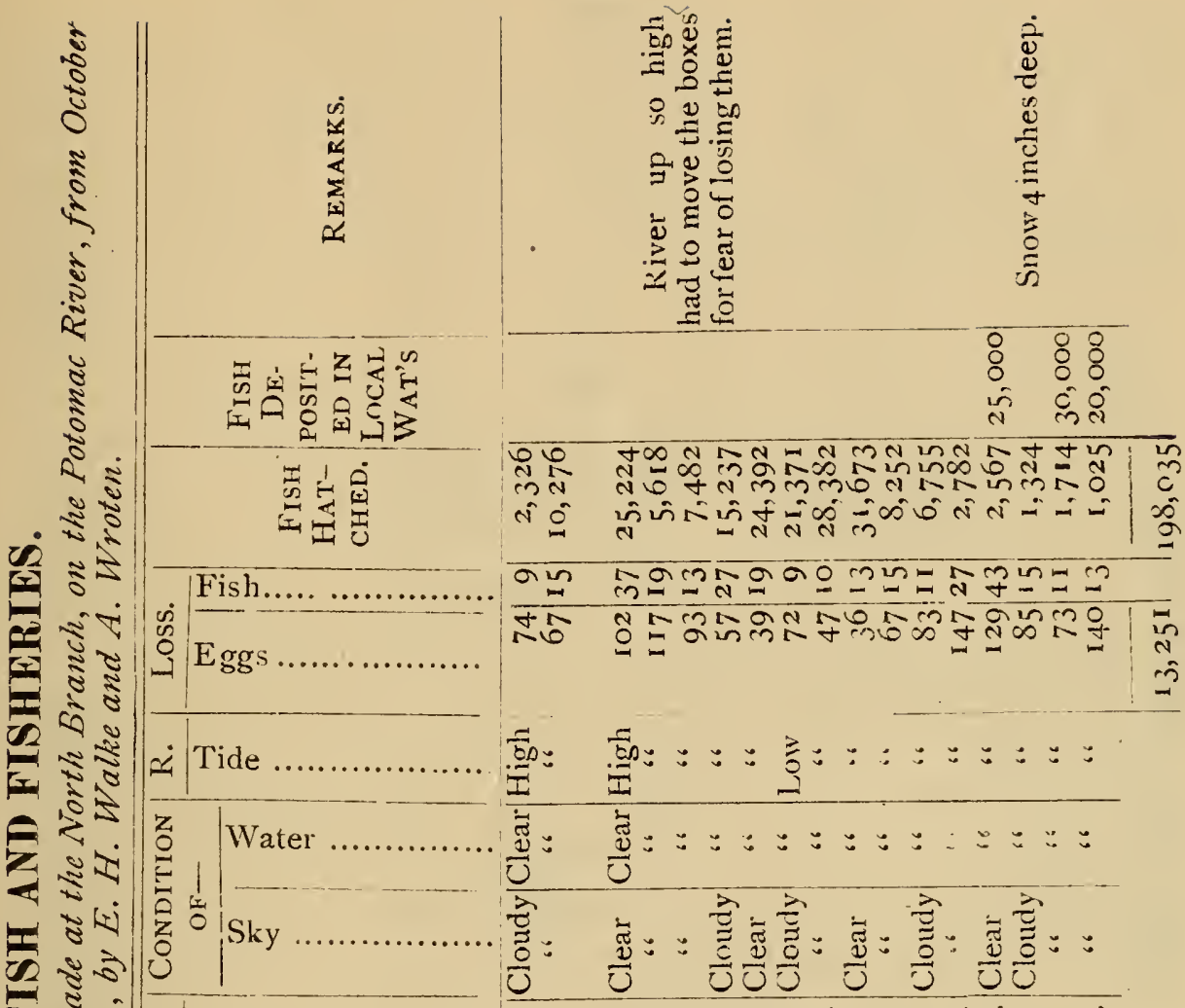

Direction ...............

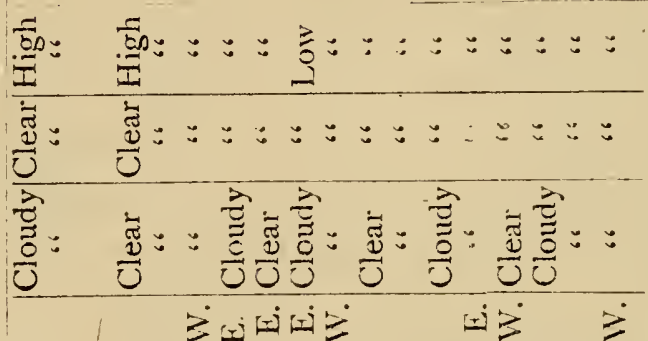

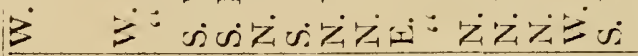

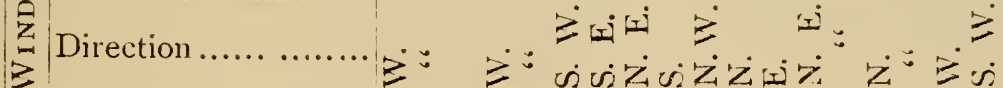

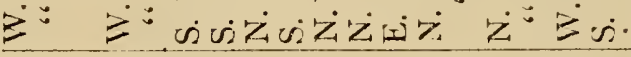

Direction ............

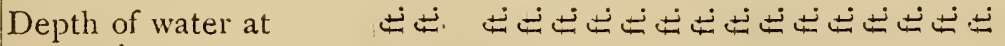

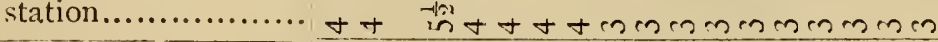

E Bottom ............. 开文

| ¿. Surface Water .... 更

to in Air ................ in

Buttom ..........

¿ Surface Water .....

寸寸

寺京

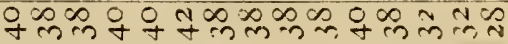

\& $\mathrm{Ai}$

Bottom .

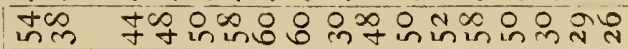

o

Gi

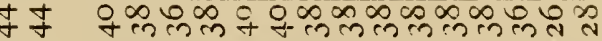

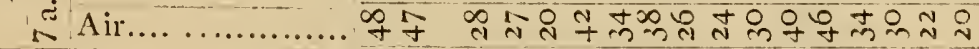

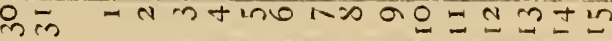

岁

8

Day of Month .... i m

$\vec{D}$

$\vdots$ 㲾

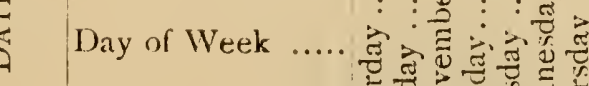

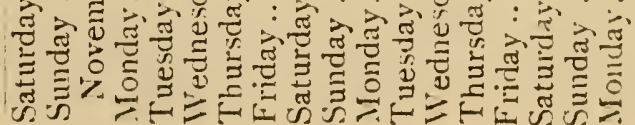




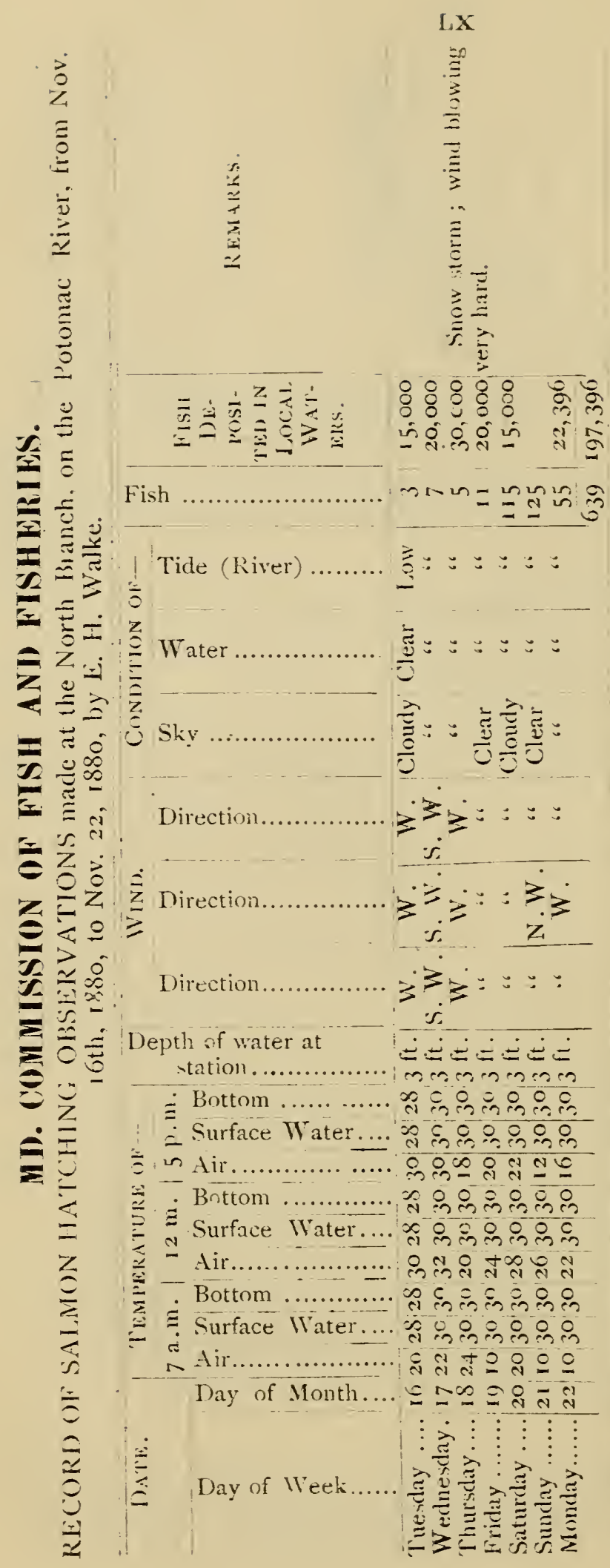


The experts in tish culture who visited this station during the development of the eggs, pronounced the eggs and young fish in the most healthy condition; and there was a marked differece between the appearance of the fish hatched in these pure cold waters and those hatched in the warmer waters of the hatching-house in Druid Hill Park.

I am convinced that by neans of this system of moveable hatching apparatus our streams can be much better stocked with the salmonidx than by the system hitherto pursued of developing the eggs in hatching-houses and transferring the young fish thence.

- Colonel Hughlett, the Commissioner of Fisheries for the Eastern Shore, having received a like number of eggs from the U. S. Commissioner, the resources of the Druid Hill hatching-house were placed at his disposal for their proper care and development, it being also considered that Baltimore was the most convenient point for their distribution to the waters of his district, as the several lines of transportation centre in that city.

Ten thousand young fish of this lot were kindly turned over to me by Col. Hughlett, 5,000 of which were placed in the head waters of the Gunpowder River and the rest in the Patuxent near Savage Station. The few young California salmon hatched at the Druid Hill hatching. house, from eggs received in the fall of 1879 and reremaining on hand when the report of the operations of that year was submitted, were distributed, as shown in the following table, on January 6, March 9 and 25.

The table also shows the date on which the fish produced from the eggs hatched Ior Gol. Hughlett were turned over to his messenger. The names of the streams stocked and the places at which they were deposited will no doubt appear in Col. Hughlett's report. 


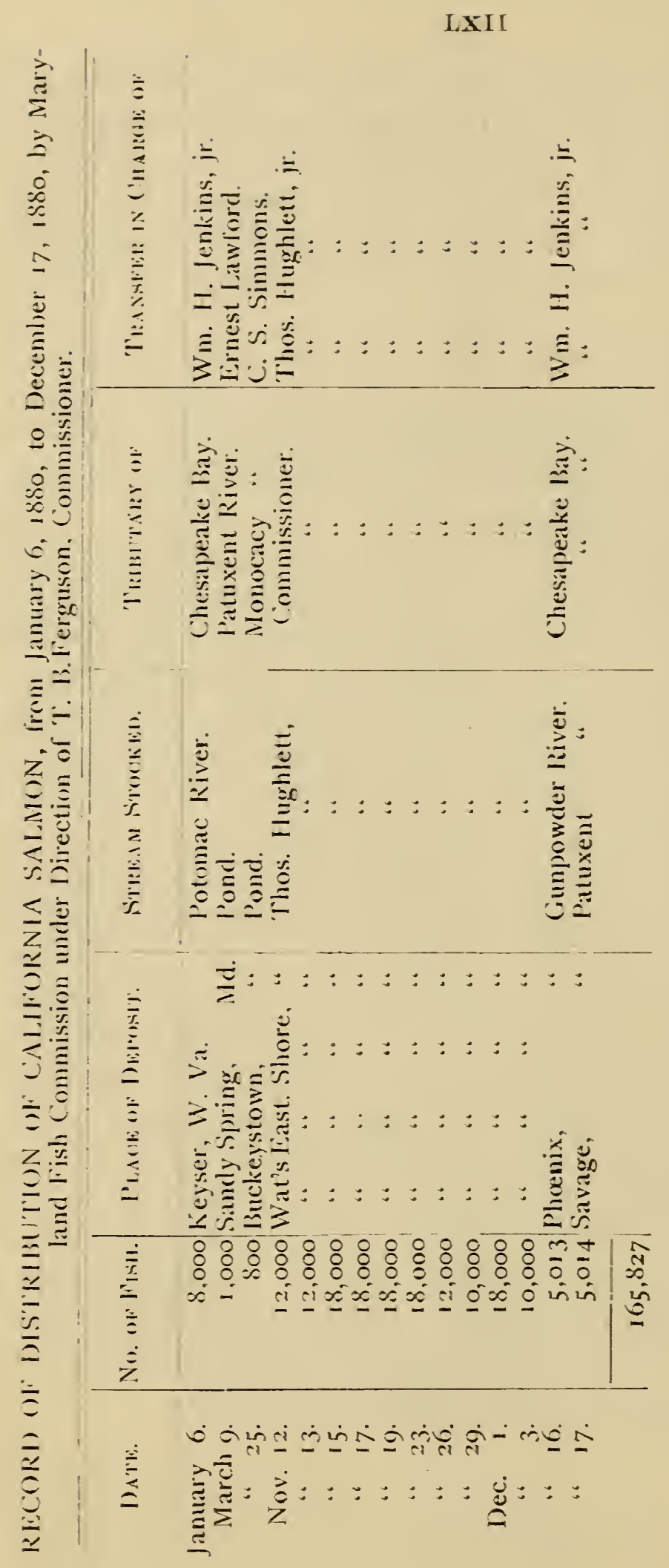


California Brook Trout-Salmo iridea.

During the two years preceding the last, a considerable number of the egg's of the brook tront were purchased and hatched ont at the Druid Hill hatching establishment, and the young fry distributed to persons who were desirous of stocking their streams with this fish. The means at the disposal of the Commission did not warrant a further expenditure during the year 1880, and we are indebted to the liberality of the U. S. Commissioner for a supply of trout eggs obtained from the trout common to the streams of the Pacific slope. And as this member of the trout family not only grows more rapidly than the eastern species, but attains a larger size, and is found in much warmer waters than those inhabited by its cousin of the Atlantic states, I have deemed it of importance to attempt its introduction into the waters of Maryland.

Several consignments of these eggs received from the U. S. Commission were successfully hatched and were distributed under the same regulations that had been established for the distribution of the salmo fontinalis.

The accompanying tabulated statement of the distribution of the California trout will show the waters in which they were placed. 
I. X I V

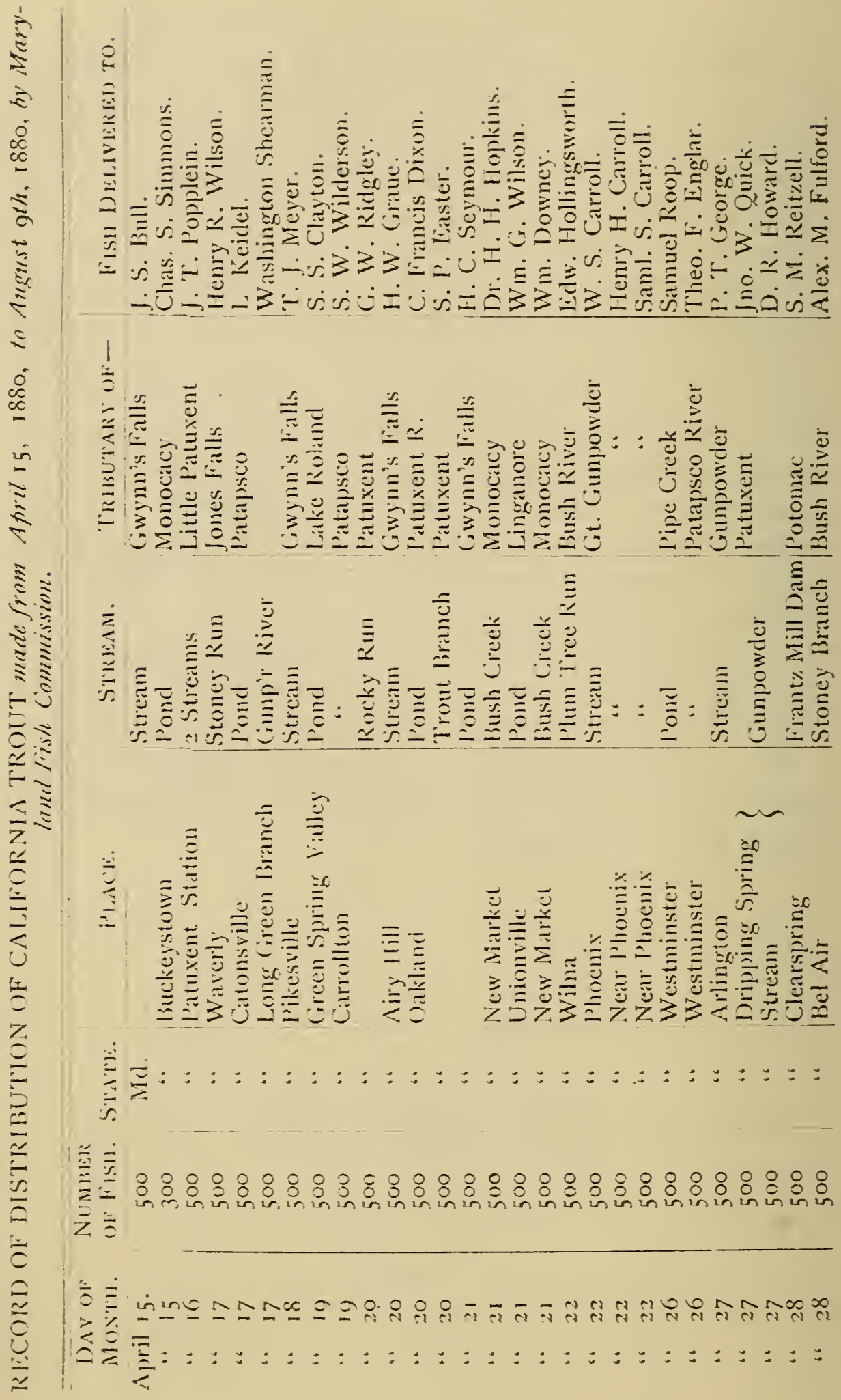




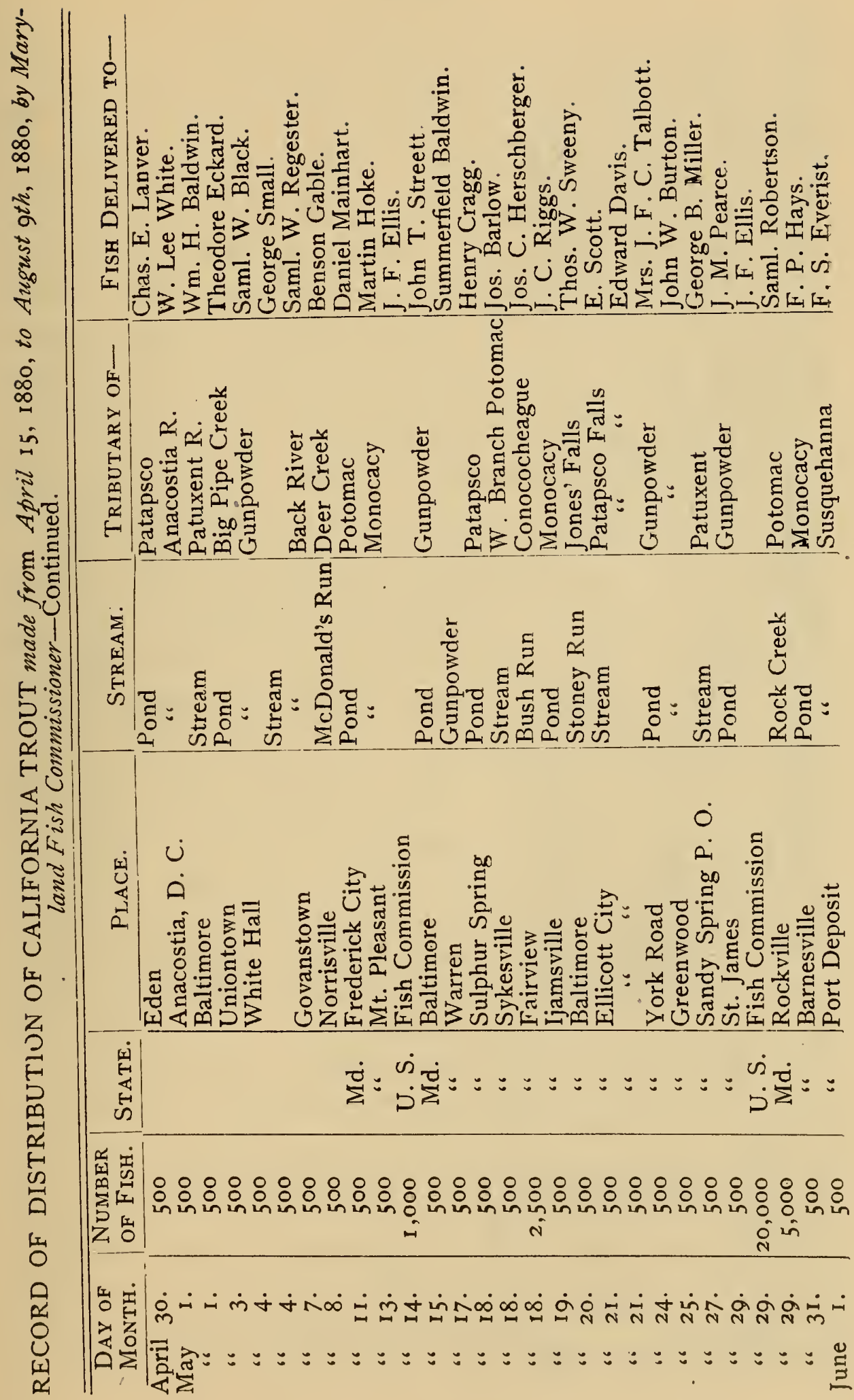




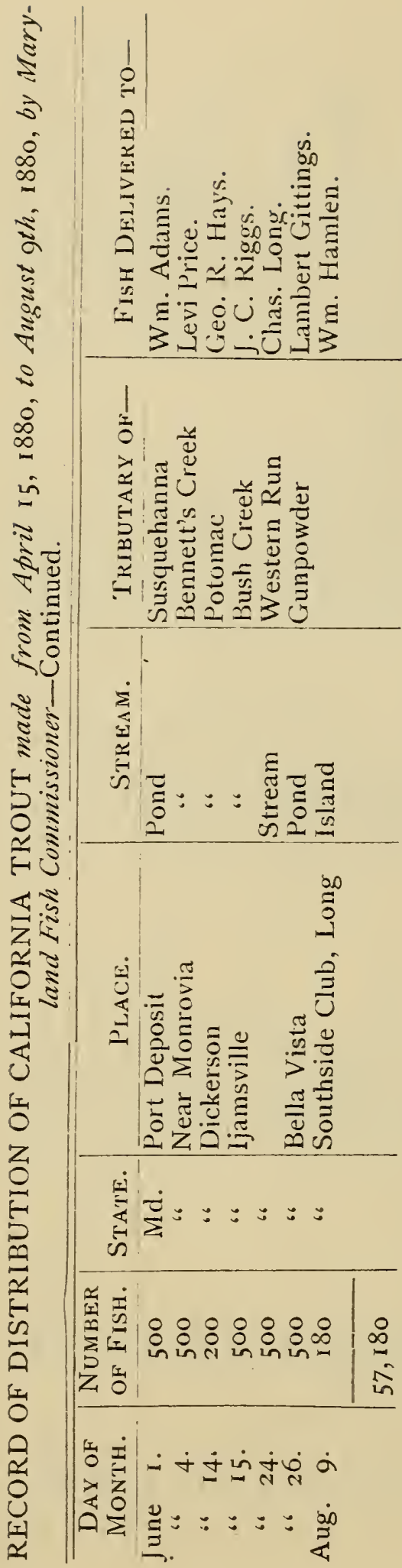


The Carp.

The supply of German Carp for 1879, derived from the increase of those which had been deposited with us by the United States Commissioner, enabled us to distribute during that year 6,135 young fish; which were given to such persons only as had ponds suitably prepared for their reception. The extraordinary success which had attended the cultivation of those previously issued having aroused a lively demand for these fish, the few hundred that were on hand at the opening of the year were all distributed by the middle of January-to the great disappointment of a large number of applicants, whose orders we were necessarily compelled to leave unfilled.

The Carp distributed throughout the State of Maryland are mostly of the two kinds known as the "Scale," and the "Leather" (or scaleless) varieties - the latter being the result of careful selection and breeding are held in somewhat higher esteem.

The Scale Carp, however, from which all our stock is derived, were imported by Professor Baird, some years ago, from the best ponds in Europe. They were so carefully selected by his agents, with reference to purity of stock, that they often produce individuals of the "improved," or "Leather," variety-young fish almost entirely destitute of scales being frequently found in the same brood with those holding more closely to the original type.

It is of interest, in this connection, to record the fact that the fish which have been distributed in the United States, as well as those retained in the breeding ponds at Druid Hill Park, and in the government ponds at Washington, have shown a most remarkable annual growth-greatly in excess indeed of what has ever been observed, for a corresponding length of time, in the case of those bred in their native waters.

This phenomenal development may be readily account- 
ed for, however, when we consider that the Carp not only find in our waters the greatest abundance of natural food, but that the comparative mildness of our climate permits them to feed through a much more extended portion of each year than is possible in Northern Europe, where long and rigorous winters condemn them to extended periods of hibernation.

The fact of such relative rapidity of growth has at least been clearly established, and affords a new evidence -as gratifying as it was unexpected-of the complete success which has rewarded the efforts of Prof. Baird to introduce this valuable tish into American waters.

Reverting to our narrative of operations for the year 1879, the ponds in Druid Hill Park were drawn early in May, all eels, frogs and fish inimical to the Carp found in them were destroyed, and a number of aquatic plants were set out to serve as food for the fish and as receptacles for their eggs.

On the 7th of the same month the breeding fish were placed in ponds Nos. 3 and 4-thirty-one Leather Carp being deposited in the former, and one hundred and three in the latter. A few Mirror Carp of varying sizes were also placed in pond No. 4, and a few young Carp in pond No. 1-our main dependence being, of course, the adult fish in ponds Nos. 3 and 4. The imported Golden Ides were still kept in pond No. 2.

Immediately after being returned to the ponds the fish commenced to spawn, and it is quite likely that the drawing of the water, and disturbance of the fish so near their spawning time, was so far detrimental to them that the yield for this year was somewhat decreased in consequence. A number of twigs and blades of water grasses on which the fish had deposited their eggs were taken from the large ponds, with the eggs attached, and were placed in the brick ponds adjacent to No. 2, which had been especially prepared with a view to the purposes of artificial breeding. In a few days the 


\section{$\operatorname{LXIX}$}

eggs commenced to hatch, and we soon obtained from them a considerable number of young fish. The large breeding ponds-in which the adult fish had been placed. -were not disturbed again until late in the fall. During the summer the ponds were greatly depredated on by herring; kingfisher's also occasioning us much annoyance, until the Park Commissioners kindly authorized the attendant to shoot these birds, when their ravages were somewhat abated.

As the attendant was, necessarily compelled to be absent from the ponds for a considerable time each day, the kingfishers continued their depredations to a troublesome extent, until a plan for their destruction was suggested by Admiral Ammen, which, as it proved effective, I take pleasure in repeating here for the benefit of culturists whose ponds are subject to the raids of these feathered robbers. In accordance with his directions, several poles were placed upright around the edges of the ponds, each pole being armed at the top with a small steel-trap, set with quite a delicate "trip." The kingfishers and other predacious birds when approaching the ponds naturally select these poles to perch upon as affording favorable positions from which to scan the waters and fall upon their prey; they light, of course, upon the trap which springs to the touch, and either captures them or inflicts a fatal wound.

I am satisfied that the number of fish-especially of the Golden Ide-destroyed by these birds, before the war of extermination commenced, was very considerable, the brilliant color of the Ide making them very conspicuous objects in the water, at the same time that their habit of swimming near the surface renders them an easy prey to their enemies.

In order to secure the young Carp for distribution, we commenced to drain the ponds again on the 20th of October, and again freed them of eels, catfish and other enemies which had accumulated during the summer. 
The Carp were immediately assorted, the larger ones being returned to the ponds, while those four or five months old were placed in tanks at the hatching house for distribution. Of the latter it was found that we had available for issue twenty-five thousand seven hundred and eighty-tive $(25,785)$ Scale Carp; eighteen hundred and sixty (1860) Leather Carp, and eighteen hundred and twenty-five (1825) Mirror Carp, a very large increase over the crop of the preceding year. The distribution was at once commenced and has been continued up to the present time.

The number of fish given to any one person in 1879 was limited to ten pairs, but the greater success which har attended our efforts at propagation during the summer of 1880, enabled me to increase the allotment for that year to twenty-five pairs to each person who applied for them at the hatching house, while a very favorable arrangement made with the "B. \& O." and "Adams" Express Companies enabled me to transport the fish at small cost, and thus to distribute twenty pairs each to many persons living at a distance, who desired the fish, but could not conveniently call for them.

The following letter was mailed, prior to the distribution: to many prominent citizens throughout the State; and the attention of the public directed to the subject in various other ways:

$$
\begin{aligned}
& \text { Maryland Fish Commission, } \\
& \text { Dear Sir :- } 1327 \text { "M' St., Wash., D. C., Nov. 1, } 1880 .
\end{aligned}
$$

The propagation of the imported "Carp" at the breeding ponds in Druid Hill Park has been so successful this seaaon that I hope to be able to make a very large distribution of this most valuable fish to those persons in the State who desire to cultivate them, and I have made arrangements with the "Adams" and "Baltimore and Ohio" Express Companies which will enable 
me to supply the wants of applicants much more conveniently than heretofore.

Last season I issued to each applicant twenty (20) fish, but it was necessary for the parties desiring them to send to the hatching-house in Druid Hill Park for their respective quotas. I am happy to announce that I can now send the fish by Express, through the co-operation of the Companies above mentioned, to any of their stations. This arrangement will save applicants much trouble and expense. I would much prefer, however, to issue the fish at the ponds; and, in order to induce those wishing them to come for them, will issue ten fish, in addition to the usual number supplied, to those who come for them, and who thus relieve us of the necessity of shipping.

The number of fish that will be sent to parties desiring them will be fixed, for the present, at forty. The cost of wagoning to the station, express charges and return of the cans to the Druid Hill Hatching House, will be two dollars (\$2.00), which amount will be collected by the Express Agent on the delivery of the fish. The parties receiving the fish must be provided with a vessel to which the fish can be transferred on their delivery. The number of transporting cans belonging to the Commission is limited; and there is, of course, an urgent necessity for their prompt return.

I have received the most encouraging accounts of the success which has attended the cultivation of this fish by those who have hitherto been recipients of them ; and it bids fair to fill a want which has been much felt in this State. This fish is so admirably adapted for domestic purposes, that every one in the State who has even a small pond, such as is usually devoted to the collection of ice, should prepare it for rearing the carp, which being largely a vegetable feeder can be raised at very little expense, and can be utilized for the consumption of the waste of the kitchen and garden.

I trust that the arrangements which I have made will 
enable rou and your neighbors to avail yourselves of the advantages presented by the introduction of this fish into the United States by Prof. Baird. Should you or any of your friends desire to have the carp sent, please address me as above.

I am very truly yours,

T. B. FERGUSON,

Commissioner.

In accordance with the arrangement already referred to, the Superintendents of the Express Companies issued the following instructions to their agents :

\section{SUPERINTENDENT'S OFFICE, Baltimore, Md., Nov. 1, 1880. Agent.}

"Several shipments of live fish will be made by the Commissioner of Fisheries to parties in the neighborhood of your station. In delirering them to the consignee, you will in no instance issue the ressels in which the fish are sent. The parties receiring the tish must proride ressels for their remoral to the ponds.

A blank receipt will be forwarded with each shipment, and you are required to hare the same filled up and signed by the consignee, and return the receipt to the Commissioner of Fisheries.

Should the fish not be promptly called for. you are requested by the Commissioner to change the water in the cans once or twice a day, or whenerer the fish show signs of distress by coming up and remaining at the top of the water.

If the fish are not delivered within 5 days after their arrival, you will report the fact to this office and await instructions. After delivering the fish return the empty cans as soon as possible to this office, regularly waybilled FREE."

How widespread has been the demand for the Carp 
and the extent to which the Commission by satisfying that demand has enabled the people of the State to enter upon the important work of cultivating this valuable fish, may be ascertained in part by a perusal of the following tables, which show only the distribution made under my immediate direction, a large additional number having been turned over to my colleague, Col. Hughlett, for distribution in his neighborhood and not being included in this statement. As the supply of Leather Carp was considerably smaller than that of the Scale Carp, I secured from the U. S. Commission a number of the first named variety; and sixteen hundred (1600) of these, as well as two thousand Scale Carp from the ponds at Druid Hill Park, were turned over to Col. Hughlett to supply the wants of those who had applied directly to him: 


\section{LXXIV}

垔

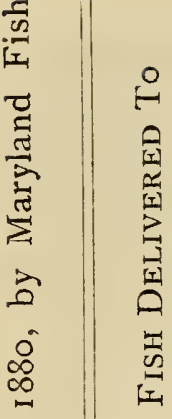

我

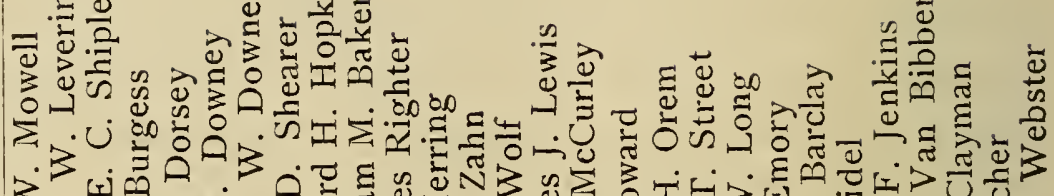

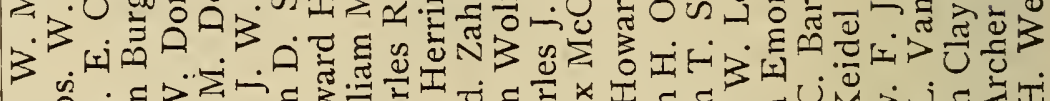

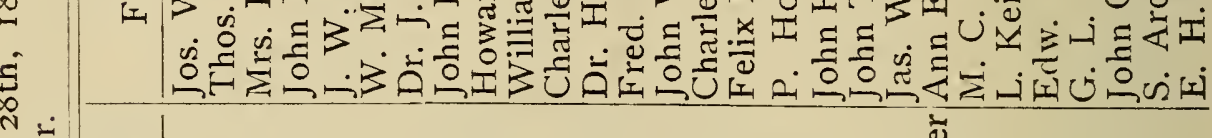

हैं 空 至

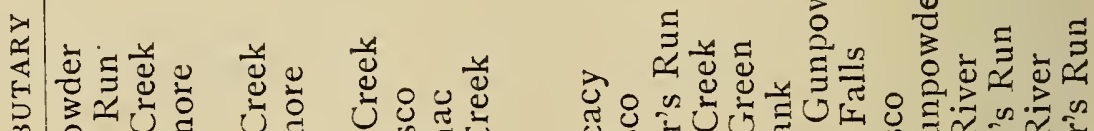

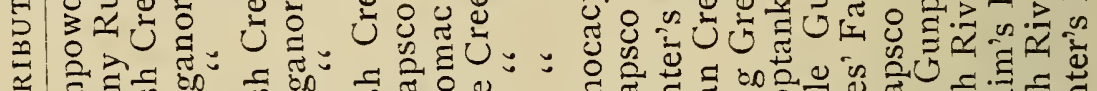

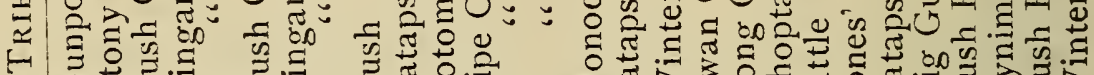

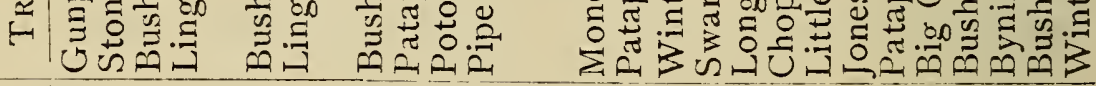
|

छุ๊

눙

छ

A.

更

Z

$\sum \equiv$

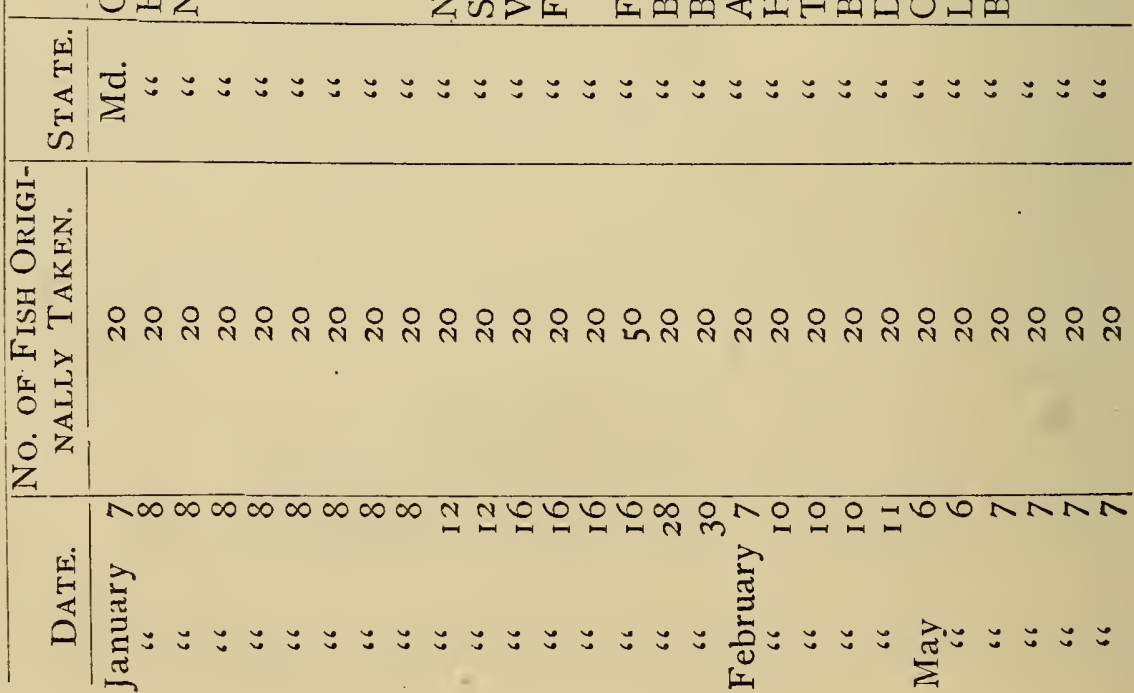

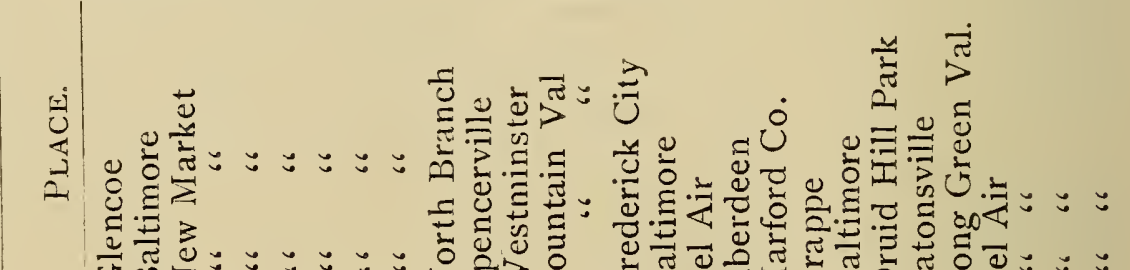

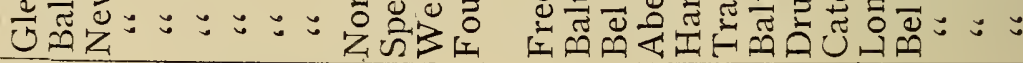

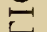

$\stackrel{b}{0}$

$\approx$

is

A

年

8

$\bigcup_{(1)}$

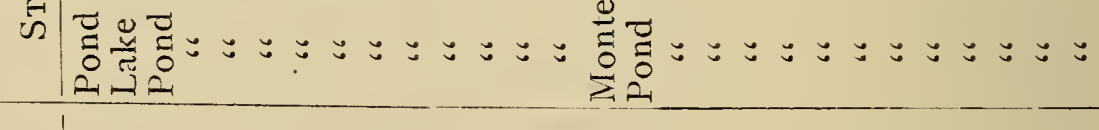


LXXV

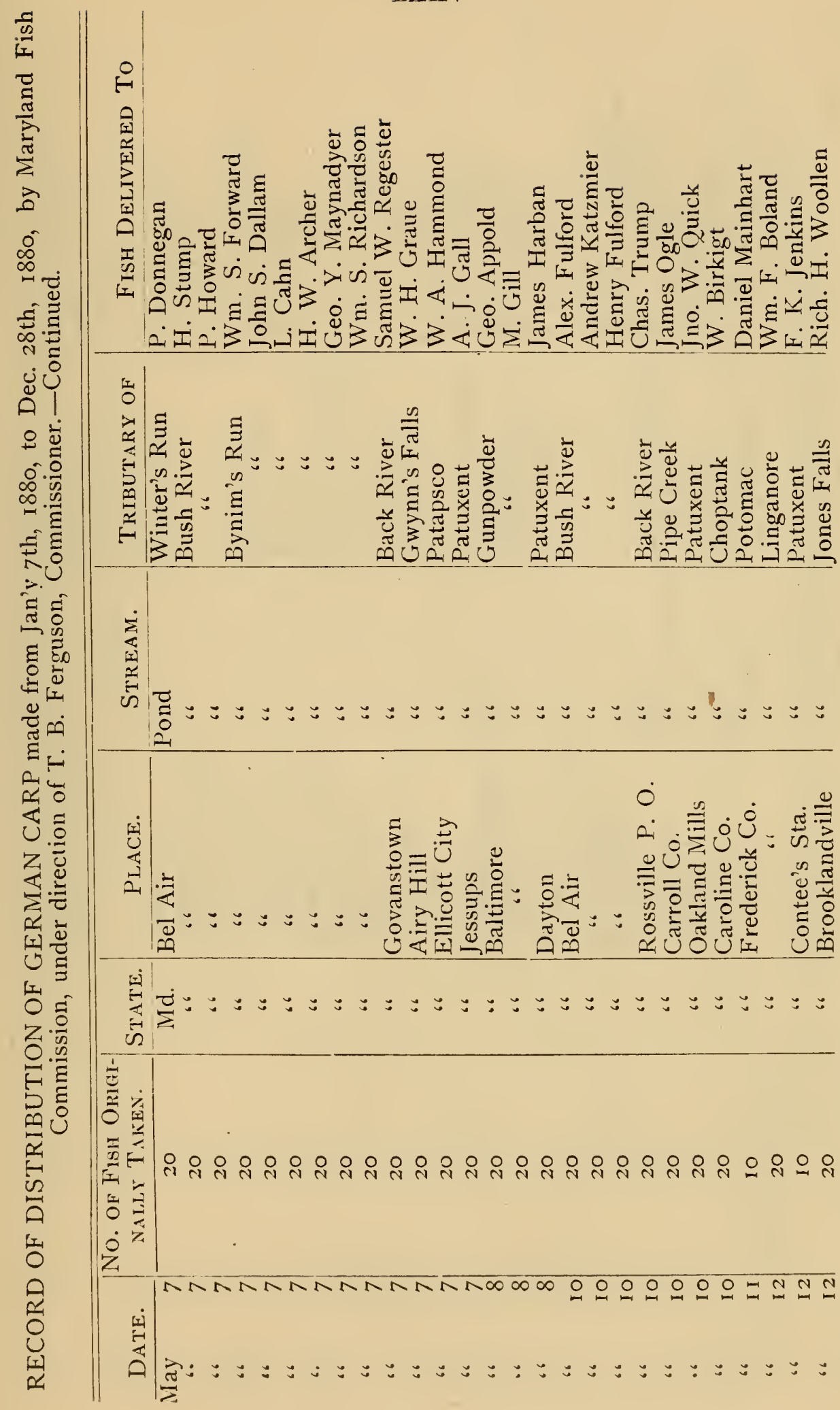


LXXVI

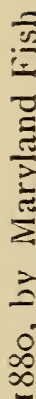

$\frac{1}{5}$

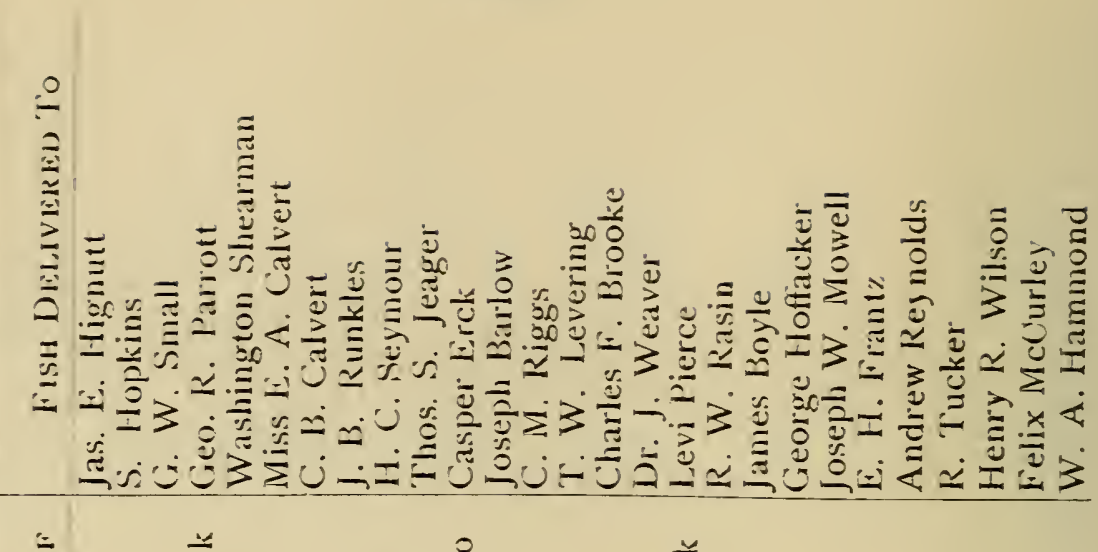

仓ัن

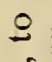

象

突芯

๖

‡

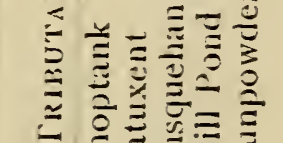

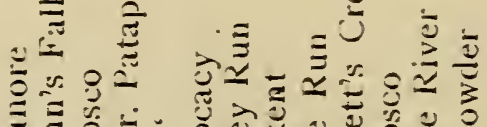

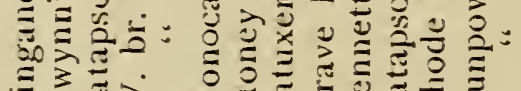

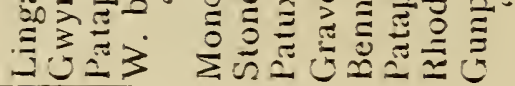

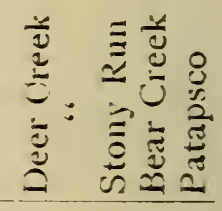

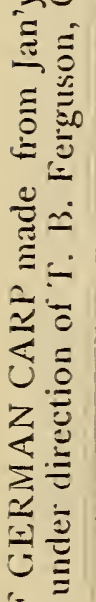

-

证

=

(c)

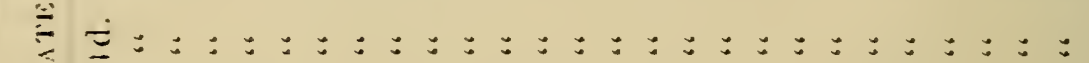

Z.

$\underline{\underline{\Xi}}$

Ð

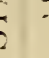

$\frac{1}{0}$

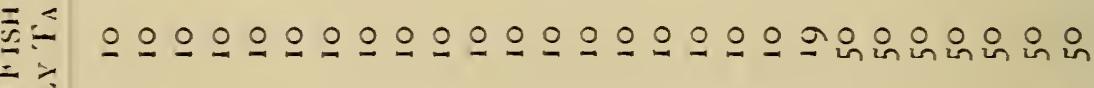

$\underline{z}$

$\frac{12}{12}$

2

它

a $\quad$ a

苾

$\stackrel{3}{=}$

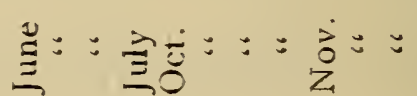


LXXVII

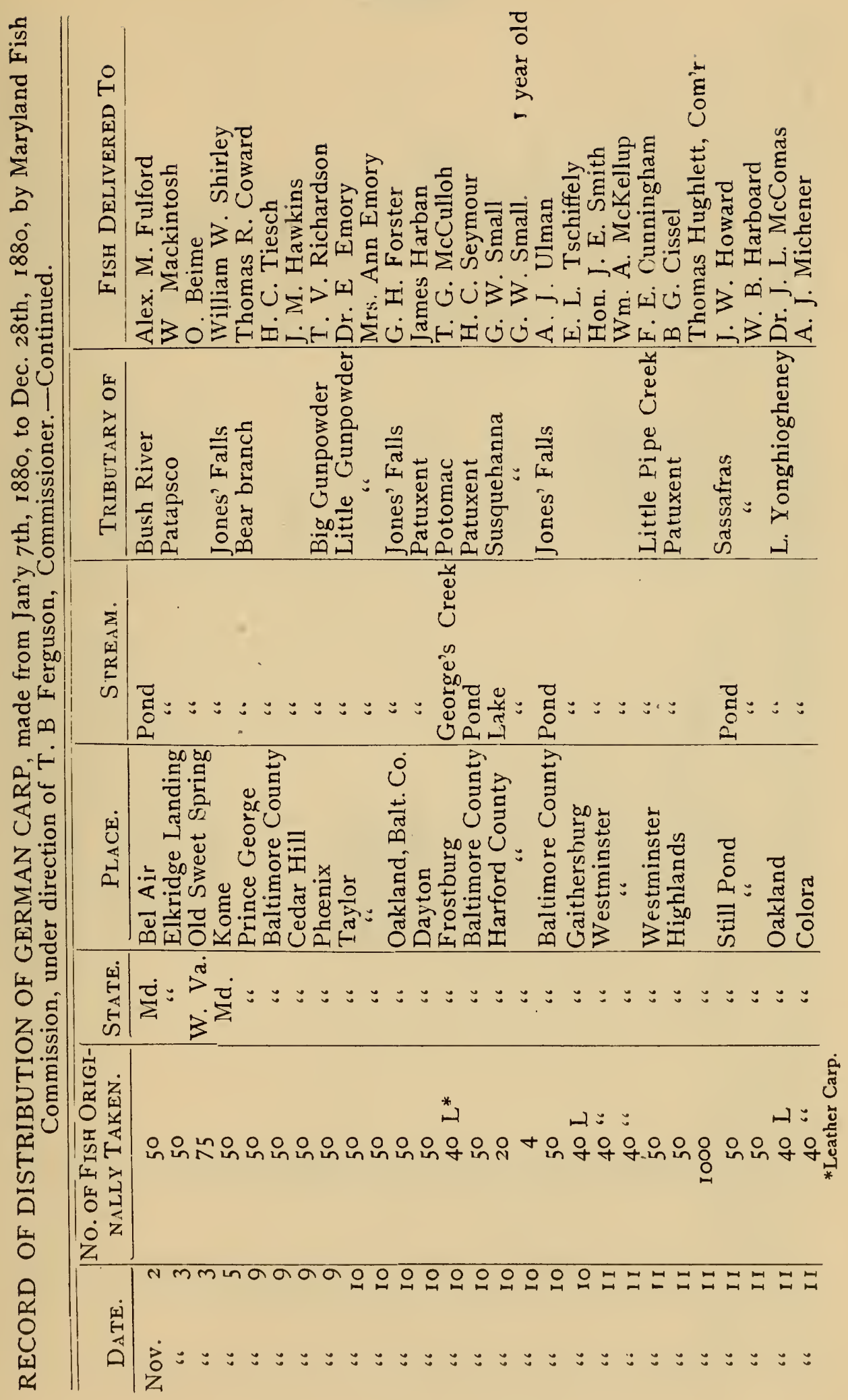


LXXVIII

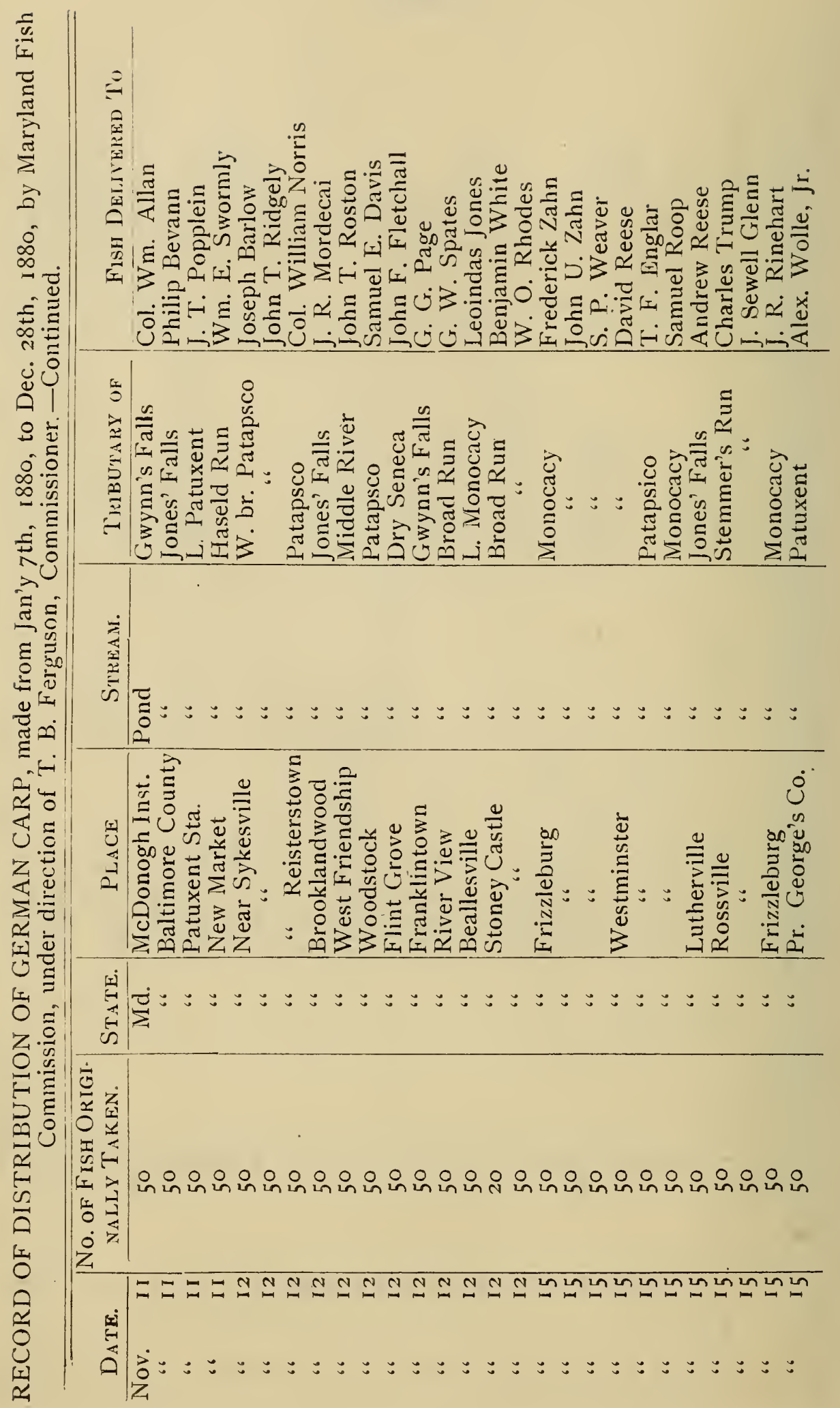




\section{LXXIX}

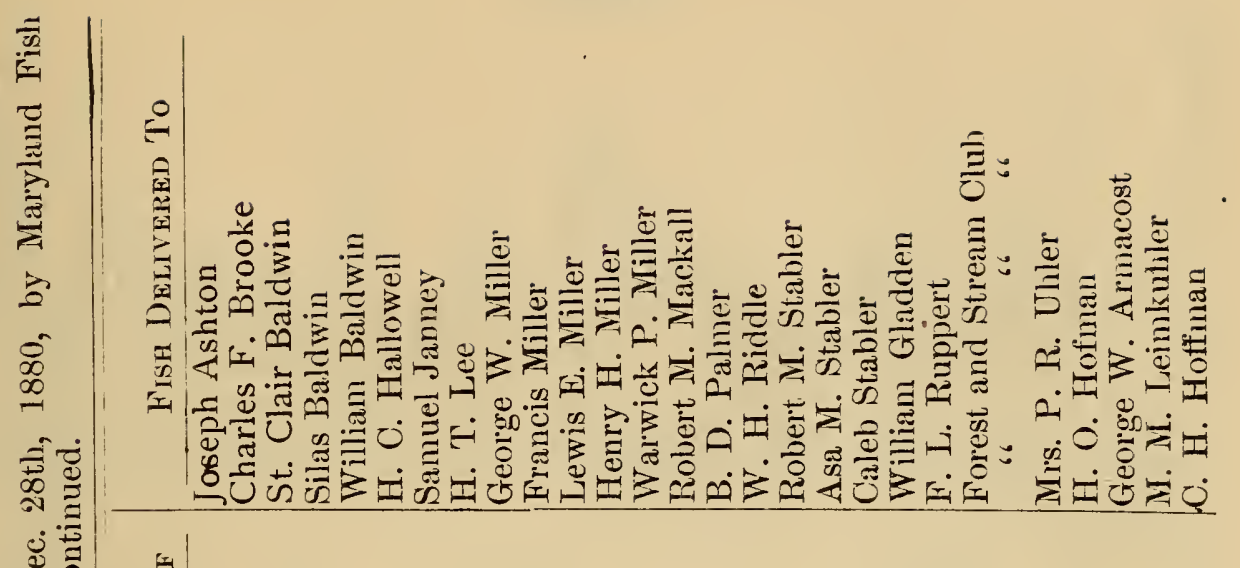

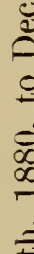

E

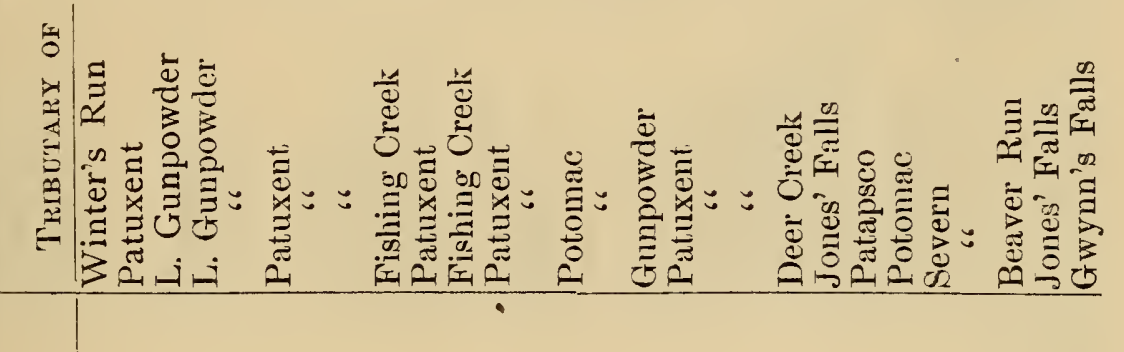
בี⿻

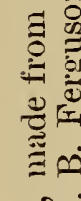

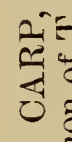

密新

等

를

空

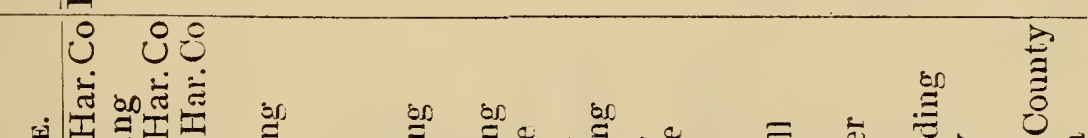

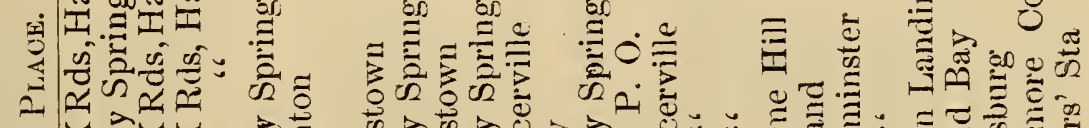

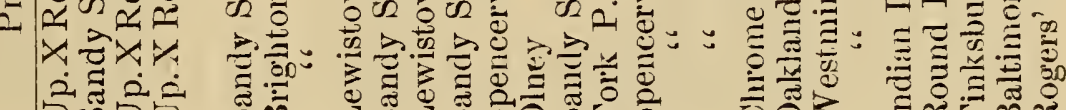

等 |

똥

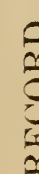


告

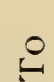

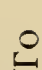<smiles>[As]=[As]</smiles>

त्ञ⿰冫欠

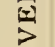

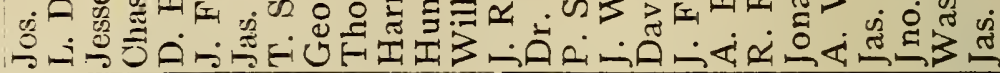

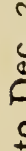
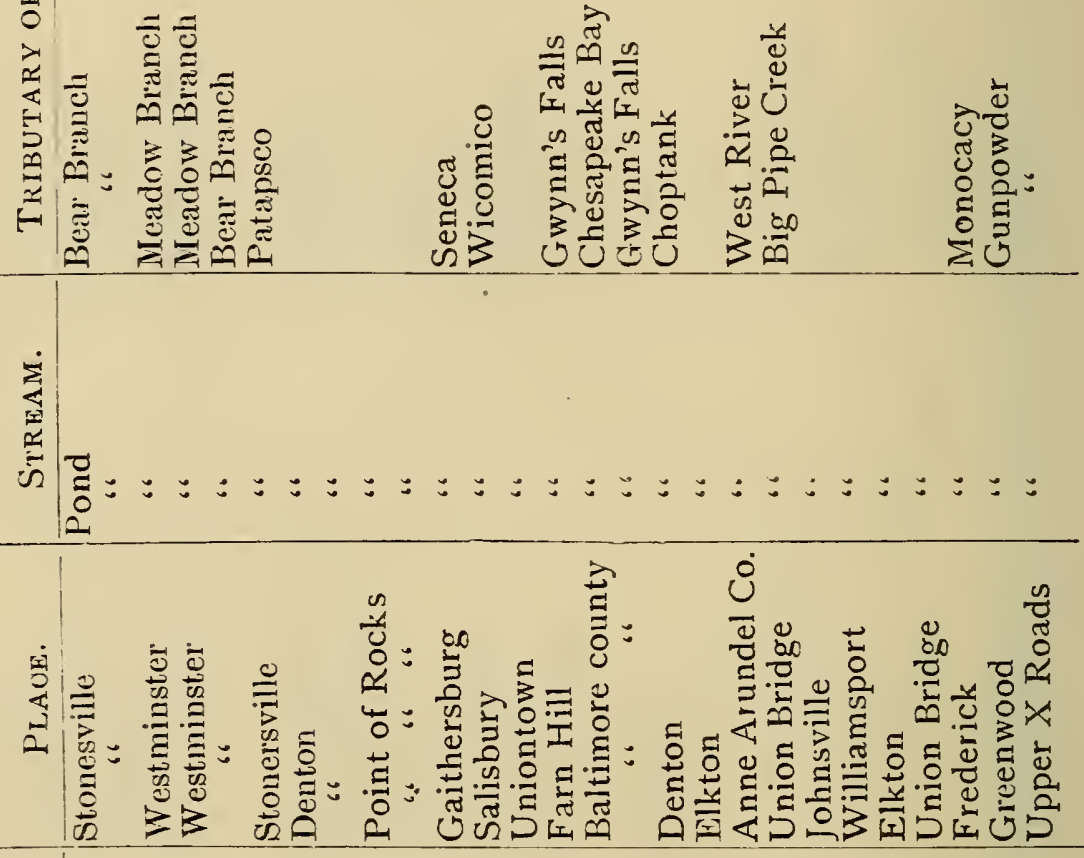
is

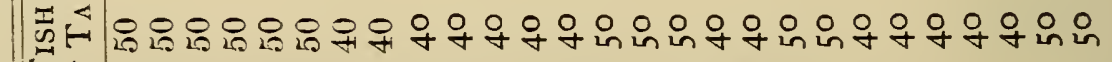

$\overparen{a}$

s

8 


\section{XXXI}

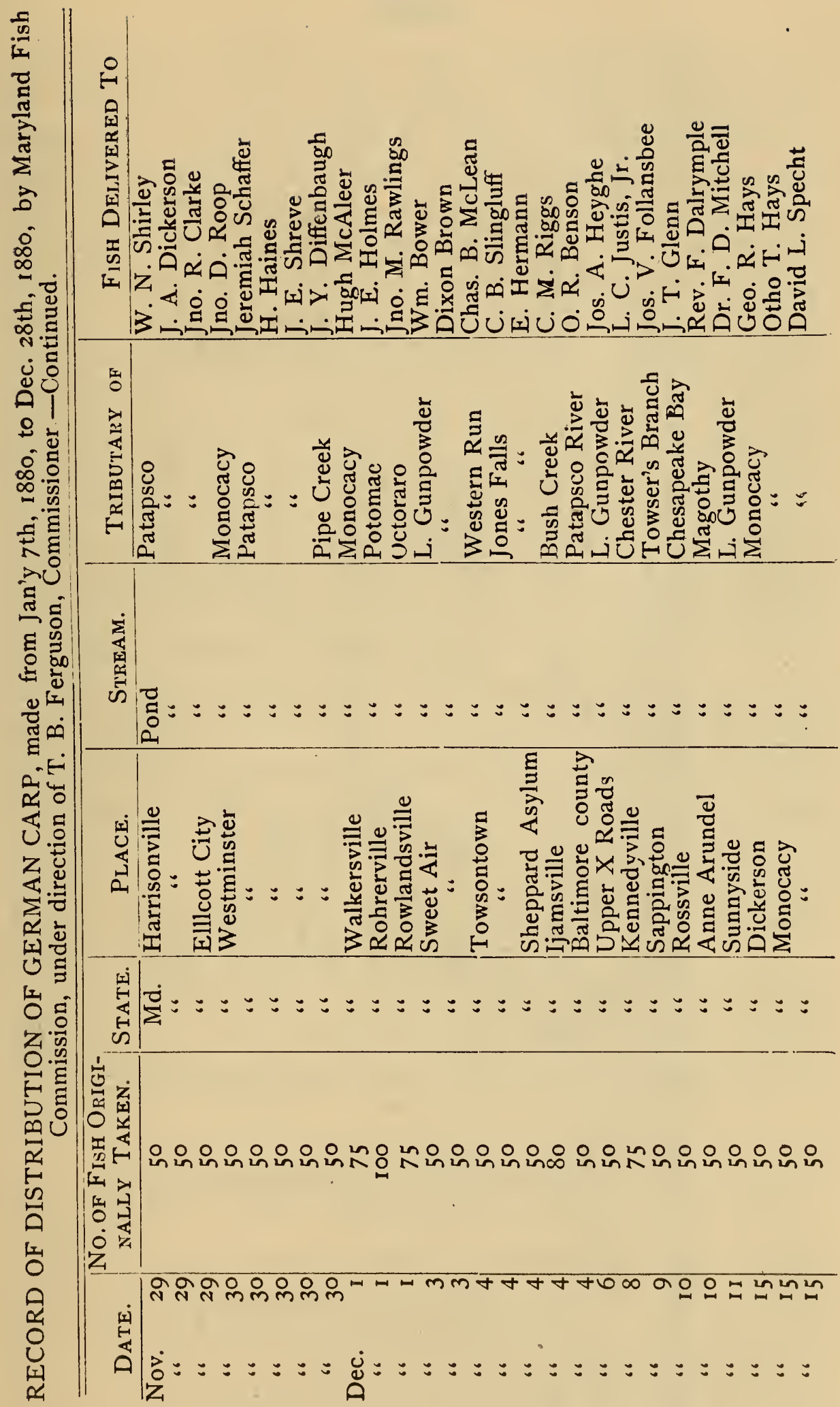


LXXXII

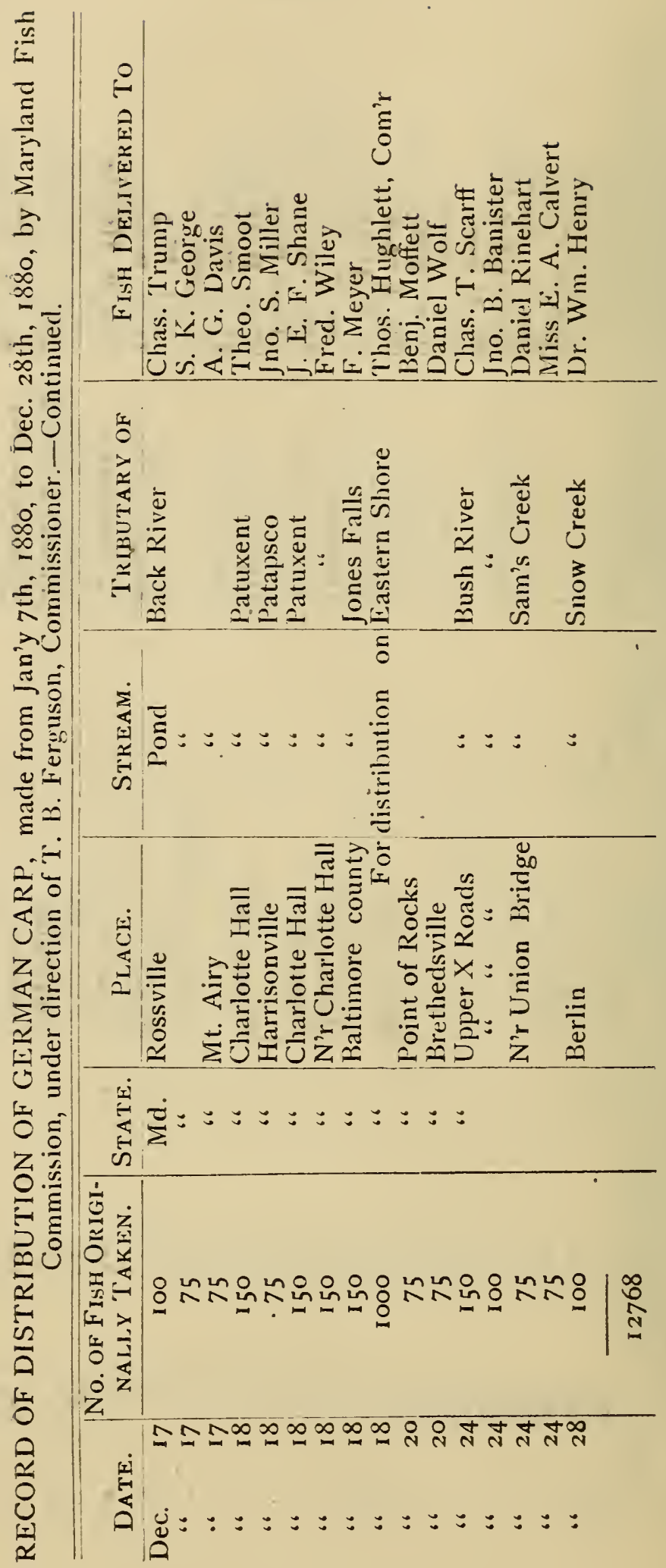




\section{LXXXIII}

Although puplic notice had been given, early in the fall of 1879, that the fish could be had by applying for them at the hatching house, many persons neglected to make application until late in the following spring, when the supply had become exhausted, and much disappointment was experienced in consequence of our inability to meet these tardy demands. Fearing a repetition of this procrastination and that the farmers would again postpone sending for their fish until the last moment, I limited the early distribution, for 1880, to 25 pairs to each applicant ; it being considered that, if properly cared for, that number would be adequate to the stocking of a very large extent of pond. As the season advanced, however, and the supply of fish remaining in hand was apparently in excess of what would be required to meet the prospective demand, the number given to each applicant was proportionally increased.

The Carp, as has been before remarked, grow much more rapidly in this country than in Europe, and it is quite likely that the fish issued during the winter of 1880 will spawn during the summer of 1882 . If this should prove to be the case and the young fish thrive as well as there is every reason to expect they will do, it will not be very long before they will become plentiful in numbers in all the waters of the State.

As an indication of the success which has attended their cultivation in all parts of the United States, I make the following extracts from reports made by those who have received them:

Kosse, Limestone Co., Twxas, June 28th, 1880.

Dear Sir :-

The German Carp sent Sam'l Bell and me last fall are doing as finely as any one could possibly ask. When they arrived there was very little water in our pond, so we put them in a well with about four feet of water in it, and connected the well with the tank by means of a 
small ditch, letting the tank water fill it up; the ditch was left open so that the water would not stagnate. We put five of them in the tank (or pond), and fed all of them on corn bread and vegetables that had seed, such as tomatoes, squashes, etc., all of which they ate. They seemed to like the squash best and preferred it baked. * * * * They are now about four inches wide and a foot long. Corn bread is their favorite diet, and by feeding them at the same place every day they become accustomed to look for it, and now all we have to do when we wish tolook at them is to tie a piece of stale bread to a string and float it on the water, when they come up all around it and scramble for it as hogs do for corn. There are numerous parties in this neighborhood with good ponds who want to know whether they can get any this summer or fall. Please let me know at once as fish in this section are scarce and high, and the Carp seems to be the fish.

Yours truly,

VOLNEY METCALF.

Dear Sir :-

Rixford, Fla., Aug. 5, 1880.

It will doubtless be a pleasure to you to learn that the Carp you furnished me with last November are doing finely. I ascertained on my return from Savannah with them, that my pond was not ready for their reception, owing to the fact that there were many more black-bass in it than I had supposed. I accordingly confined the Carp in a pen at the side of the pond, giving them water through holes in the side, covered with wire netting. A few weeks since I discovered that a portion of the netting had been displaced and some of them had escaped into the pond, and I then concluded to let them all into it, as I had nearly all the bass out. Their growth since that time has been simply marvelous.

Sincerely yours,

GEO. C. RIXFORD. 
LXXXV

Howard County., MD., Oct. 9th, 1880.

* * *. * I received from your assistant, at Druid Hill Park, ten of the Scale Carp in May last. They were then about three inches long, and in digging the pond larger in August, ( 3 mos. afterward,) I let the water off to catch them and put them in the smaller pond, when I was surprised to find them from seven to ten inches long.

I have no other fish in the pond, and as the ten have done so well would like very much to get some of the Smooth ones.

Yours truly, * JOSEPH BARLOW.

Columbia, S. C., Oct. 18, 1880.

$\underset{*}{D e a r} \operatorname{sir}:-$

I have the most encouraging reports of the Carp distributed last November; some are ten inches in length and weigh one pound.

A. P. BUTLER, Comr. of Agriculture.

The Fish Commissioners,

Dear Sir :-

RoMney, W. VA., Oct. 29, 1880.

I have been extremely anxious to secure some more Carp. It is the only fish in which our people seem to take interest, and affords speedy evidence of the importance of our work. Of those received last fall we retained twenty-six in the hatchery ponds. Have them all yet, some weighing considerably over a pound. I am, therefore, very thankful for your offer to let me have more, and write to inquire where I shall send for them. * * * *

Very truly yours, C. S. WHITE.

Ber Air, Harford Co., Mo., Nov. 1, 1880.

My Dear Sir :-

Through your kindness I received a few Carp from 
Druid Hill hatching house the first of last May. At that time the fish were about three inches long and weighed about $\frac{1}{2} \mathrm{oz}$. each. I caught some for our Agricultural Show on the 11th of October (last month). One of them weighed $2 \frac{1}{4} \mathrm{lbs}$. All weighed $2 \mathrm{lbs}$. or more, and averaged over fifteen inches long. They have had no attention whatever. The pond is about half an acre or more, from one foot to six feet deep. Five of the fish taken from the pond looked so well developed that I think they will spawn next February, although you informed me that they would not spawn until they were two years old.

Yours truly,

$$
\text { JOHN S. DALLAM. }
$$

My Dear Sir :-

Rixford, Fla., Nov. 1.

variety) continue to thrive splendidy, and are a marvel to all who see them-especially those who saw them when I first procured them in November last when they were only about three inches long-and who now compare them. Many of them are from fifteen to seventeen inches in length, and six to seven inches in breadth. They show no signs as yet of going into winter quarters, coming for their food regularly, and I hope to be successful in carrying them through the cool weather without their resulting to the old habit.

GEO. C. RIXFORD.

Dear Sir :-

Rossville, Md., Nov. 3, 1880.

Your esteemed favor received. I availed myself of your order last spring to get from the Fish House twenty (20) Carp. They are doing well and have grown finely. From their appearance they must be ten inches in length, and I will certainly procure my quota from the same place at the earliest opportunity.

Truly and respectfully yours,

C. TRUMP. 


\section{LXXXVII}

GERMAN CARP IN TENNESSEE.

Nashville, Nov. 25, 1880.

$*$

The Carp distributed here last year are all doing remarkably well, but those entrusted to Dr. Callender, Superintendent of the Insane Asylum, have made phenomenal progress. When placed in the ponds of the Asylum grounds the fry did not exceed one and a-half inches in length, and they looked very puny. The other day he brought into town five of the smallest he could catch in order to show Col. Akers. These would weigh one and a-half pounds, and livelier or finer looking fish could not be seen. The Doctor could not say definitely if any of them had spawned this year, though, judging from their present condition, they certainly will next spring. Every care has been given, feeding regularly and not allowing any one to disturb them. They have become so tame as to come at call to be fed.

* * * * FOREST \& STREAM.

J. H. D.

Holly Springs, Miss., Dec. 4, 1880.

Dear Sir :-

* * * * One party to whom we gave some Carp last February put them in a small highland horse pond, and about a month ago took one out, which, he says, weighed oyer three pounds. Have not examined any other ponds stocked at that time, but will do so next spring.

Yours truly,

WALLACE \& MCGOWAN.

\section{ASTOUNDING GROW'TH OF CARP.}

It is a fact, that the Carp has grown faster in America than it does in its original home; but the most wonderful story comes from Georgia. A gentleman in Macon sends Prof. Baird the following slip, from a local paper, and vouches for its truth. It says: "Yesterday afternoon 
Mr. E. Witkowsky, who owns the tan-yard on the old Confederate armory property, concluded to cut the dam and clean out the pond in order that he might introduce his new German Carp. The pond contained a large number of smaller fish, and among them Mr. Witkowsky hoped to find his four Carp, which had been put into thé pond last May. He found three of the fish ; but to his astonishment they were by actual measurement twenty, twenty-two and twenty-five inches in length respectively. The fourth escaped through the cut in the dam. These Carp were but two or three inches long when put in the pond, and their growth is remarkable." * * * *

FOREST \& STREAM, Dec. 9, 1880.

Illinois State Fish Commission,

Quincy, Ill., Dec. 14, 1880.

Dear Sir :-

* * * * During the high water of last summer a few of our Scaled Carp escaped from the pond into a little overtlow near. I secured them again about ten days ago. One of them measured twelve and one half inches in length.

Yours truly,

S. P. BAR'TLET'T.

Spencer, Owen Co., Ind., Dec. 26, 1880. My Dear Sir :-

My five Carp went into winter quarters about Nov. 10th. I estimate their weight at that time at two and a quarter pounds. I regret I was not able to get some of your fall distribution. * * * *

With respect,

C. FLETCHER.

"To one who has never witnessed such a thing before, it is an interesting sight to see fish assemble for their feed at the sound of a 'horn. Arthur O'Keefe has his lake stocked with the rare and valuable fish known as the German Carp, and the writer being on hand a few 
days ago was asked to step down to the lake and see the fish fed. Mr. O'Keefe's little boy, Johnny, gave a few blasts with a tin horn; a handful of bread was scattered in the water, and the Carp appeared by the hundreds, eagerly seizing the bits of biscuit. This fish is quite gentle, seeming to care but little for our presence, and even coming slyly up to nibble at a biscuit held in the hand. Most of those which we saw were about five inches in length, though there are many both larger and smaller in the lake." * * * *

Rancocas Stock Farm,

Jobstown, Burington Co., N. J., January 10, 1881.

Dear Sir :-

Enclosed please find receipt for the thirty-three Carp sent me in the spring of 1879 .

We put them in a pond of about four acres, about nine feet deep in the middle, muddy bottom. We did not see much of the fish during 1879, but this spring they appeared by millions. You cannot go anywhere around the pond and throw in a few crumbs of bread, but they would rise in clouds for it, from a little one just hatched to a fish 4 and 5 inches long. We gave them this season lettuce, cabbage and other vegetable matter; also bread crumbs and boiled hominy. The larger fish-those that were put in for stock-we rarely see; once in a while one will jump out of the water. I should judge that last fall they were about 10 inches long. They appear to remain closer to the bottom of pond than the small ones. Had much difficulty in killing off the snapping turtles, and large bull-frogs, with which the pond was filled. We found the large frogs would eat the fish. There are now enough for all men and reptiles. We cut holes in the ice on pond, and stick in a bundle of straw, for ventilation. This is the plan I am told they do in Germany.

Respectfully yours,

P. LORILLARD.

J. W. GRISWOLD, Agent. 
Dear Sir :-

I received thirteen small Carp (the size of my thumbnail) on the Sunday, 9th of May last, in good order, and immediately emptied them in my pond, which was not quite completed. They were ont of sight in an instant; the bottom being $\frac{2}{3}$ clay and $\frac{1}{3}$ sand, so that it was constantly rolly. Some days after I noticed the pond was full of frogs, some of large size, and as the fish had not been seen I supposed they had destroyed them. I called upon Mr. Blackford, in N. Y., soon after, but he could give me no information. In the latter part of August, the season being rery dry, I had the water let ont of the pond, and set workmen to finish digging it out with horses and scrapers. After they had been at work several days, three dead carp were seen that had been hurt with the horses; one of which I measured and was 10 inches long, and weighed over a pound. We then saw 9 remaining in the water that was but about 12 inches deep, in a small space in the centre of the pond, which we fed with crumbs of bread until the cold weather set in (in Norember), and the pond froze over with not more than 18 inches of water. When our work was complete, about Sept. first, I found my spring that had never been known to give out before, was so near dry as to give us but a small quantity of water, and I fear the ice has frozen so hard and tight that the fish will smother. The wonderful growth from 9th of May to 9th September-say 4 months-beats anything I ever saw or heard of.

I had intended to make report to you before, but did not want to report a failure. On the $23 \mathrm{~d}$ of last September I was in Washington, and called at your residence to make my report in person and pay my respects, and was told you were out of town. I shall be pleased to be enabled to report favorably next spring, or as soon as the ic gives out.

Respectfully,

DANIEL BIDWELL. 
GROWTH OF CARP IN VIRGINIA.

Gordonsvilite, VA., February 4, 1881.

Col. M. MoDonald,

Commissioner of Fisheries for the State of Virginia. Dear Sir :-

The seventeen Carp which you gave me in the fall of 1879 are doing remarkably well. In October last I caught four of them to see what growth they had made. They weighed from two and three-quarters to nearly four pounds. The largest one only lacked about two or three ounces of weighing four pounds. I am satisfied that they are just the fish for the waters of Virginia, and am sure they are the only fish suited to our ponds. General Field put 25 Carp in my pond some time since, which I understand were intended for my brother who has lately built a very nice pond. I was not at home at the time and suppose General Field thought they were intended for me. I take great interest in the fish-culture, and am satisfied you are doing a very great good by distributing the young fish in the waters of Virginia. Wishing you great success and thanking you for your kindness,

I am, yours, very truly,

H. C. BAKER.

Mt. Morris, Greene Co., Pa., Feb. 15, 1881.

Professor Spencer F. Batrd.

Dear Sir :-

It will doubtless give you pleasure to learn that the ten Mirror Carp I got of you the first of last June are doing finely and their growth is wonderful. When I received them, they were from four to five inches in length, and when last seen I believe them to be fifteen to eighteen inches long. I failed to learn the sex when I was at Washington. I received your order late last fall for some fish at Pittsburg. At that time I was very low with imflammatory rheumatism, and failed to get them. I want to construct another pond of one acre, provided I 
can get the fish of you to stock it. I want the Scale or Leather Carp; also a few Mirror Carp for the old pond. I shall await your answer before commencing my new pond. Hope to hear from you soon.

Yours truly,

J. W. LONG.

EXTRACT FROM CIRCULAR 48 RETURNED BY JAMES G. FIELD, GORDONSVILLE, ORANGF CO., VA.

In the fall of $1879 \mathrm{I}$ obtained from Col. McDonald of your office thirty-two German Carp. Sixteen of them were put in Mr. Baker's pond and sixteen in the pond of my mother-in-law, of which I have control. Last fall Mr. Baker found that his fish had developed very rapidly. He succeeded in catching three or four and found them to weigh from 1 to $3 \mathrm{lbs}$. Last month my daughter and a friend were fishing in the pond of my motherin-law and caught one that weighed four pounds. Last spring I received from Col. McDonald a lot of the "Leather Carp," but I cannot report as to their development to the present time. Next month I will get a seine and make a full inspection of the ponds of Mr. Baker and of my own. and will, if you desire it, report fully the result. I should like very much to have copy of any book or books you publish, and if I can render any service to you. will most cheerfully do it. If you will pardon the suggestion, I will say, that I think the small fry you distribute should only be given to persons who have private ponds, and who will agree that when the fish are grown they will turn them into adjacent streams. The fish you send out, if put directly into streams and large ponds full of Chub fish, Perch, Cat, \&c., will all be destroyed before they have sufficient size and strength to protect themselves or escape their enemies.
May 16th, 1881.
JAMES G. FIELD.

Tne results of the experiments of the last two or three years have shown, conclusively, that the waters of 


\section{XCIII}

Maryland are admirably adapted to the cultivation of the Carp, and it may, therefore, be confidently expected that within a comparatively short time every farmer throughout the State will have one or more fish ponds, which will prove quite as much a source of pleasure and profit as is the familiar chicken-coop or pig-pen.

Although hitherto regarded as being essentially a fresh-water fish, it is quite likely that the Carp will thrive in brackish water as well. I would, therefore, earnestly recommend to those of our citizens whose surroundings prevent them from securing ponds of entirely fresh water, that they try, at least, the experiment of cultivating this fish in such water as they are able to control. It should also be borne in mind that the Carp is peculiarly well adapted to waters which are subject to very high degrees of temperature during the summer months ; for, although it sturdily withstands the rigors of a Northern winter, it is even more at home in a warm climate; and the most favorable results have attended its introduction into our extreme Southern States.

As much of the success attainable in Carp culture must always largely depend upon the character of the ponds, and of the water with which they are supplied, proper care must of course be exercised in each case to obtain as favorable conditions as possible.

It is important in the first place that the ponds should have soit, muddy bottoms; and that they be furnished in the second place with aquatic plants-especially those producing seeds which will fall into the water when ripe. The Carp spawns in the spring and summer-often extending its breeding season into the fall months-and as the eggs upon being freed from the body of the fish attach themselves to the plants where they remain exposed to the attacks of other fish, by whom they are greedily devoured, no fish besides the Carp should be allowed in the ponds reserved for breeding purposes. The young fish, it should be remarked, usually make 
their appearance in from three or four to fourteen days, according to the temperature of the water.

CONSTRUCTION OF THE PONDS.

While it is certain that the cultivation of the Carp is of sufficient importance to the farmers to fully warrant the construction of ponds for the express purposes of snch cultivation, it is also true that there already exist in many places-and more particularly in the southern and south-eastern portions of the State-numbers of ponds such as are now. used for the collection of ice, or for supplying water to live stock during the summer could be readily converted into productive Carp ponds at a comparatively small cost. There are also many depressions of surface in the lands bordering upon some of our larger rivers, especially in the tidal region, which could be reclaimed and filled with water with but little labor, and made to answer admirably for the same purpose.

It is very desirable, on several accounts, that the ponds which are to be devoted to the cultivation of this fish should be so constructed as to permit all the water in them to be drawn off at certain intervals. By this means the fish can be readily captured and assorted without injury; when those intended for breeding purposes should be restored to the pond, and the remainder placed in tanks from which to be subsequently taken, by the aid of dip-nets or small seines, as required for market or for home consumption. The advantages of this facility of drawing off the water will be further experienced whenever the necessity arises for destroying such enemies of the fish as may succeed in effecting a lodgment in their midst.

In the case of such ponds as are supplied by the inflow of tide-water, for instance, the eggs of native fishes are often wafted in, and the fish thus produced soon commence to consume the food, and even the eggs and the young, of the Carp. By draining off the ponds once or 


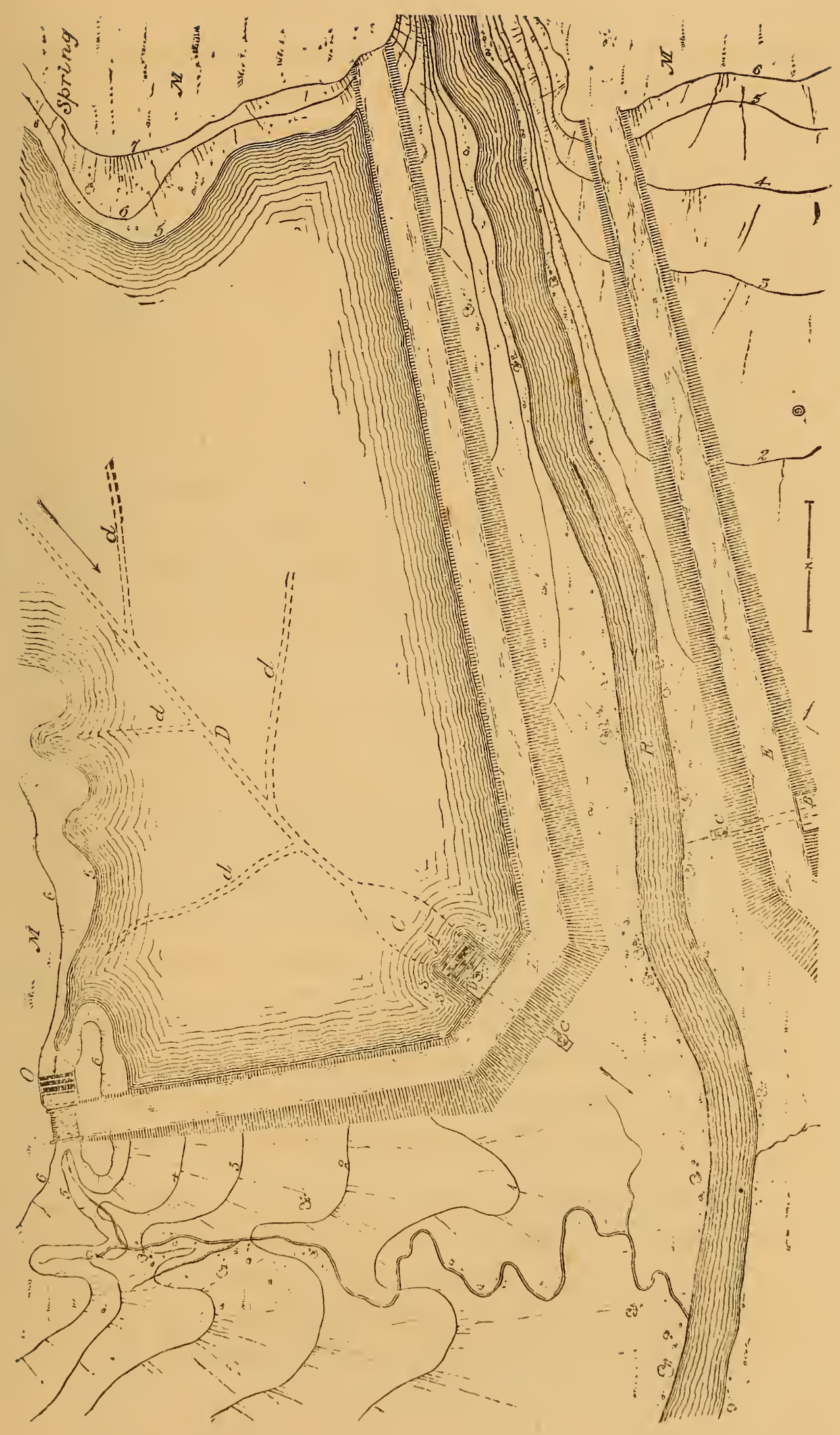





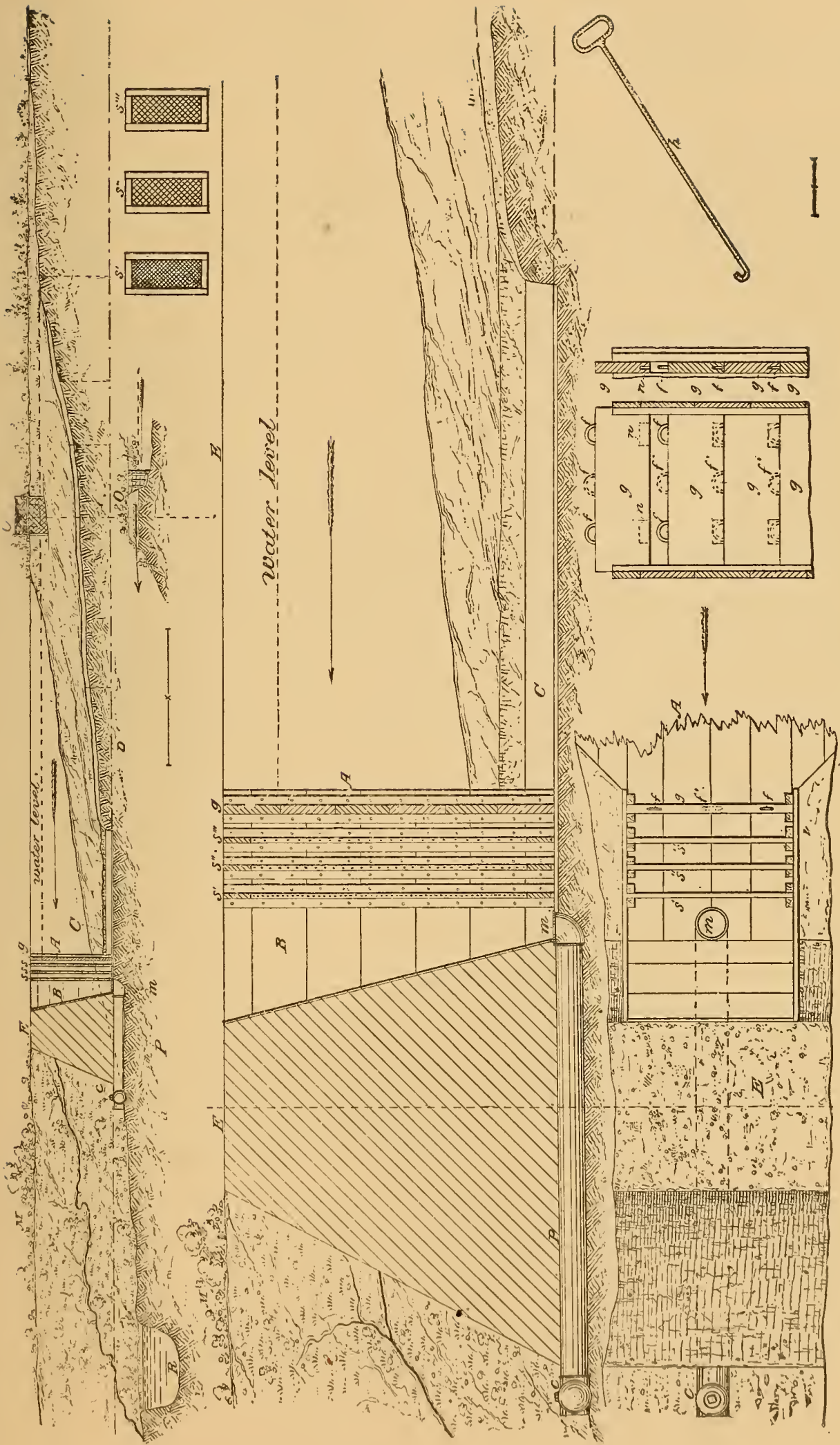



twice a year however, these intruders can be readily removed and destroyed; and the fish which are the objects of the farmer's special care be allowed to exist and multiply unmolested.

When the utilization of an ordinary ice-pond for Carp culture is contemplated, the essential points to be regarded are so simple that it is only necessary to suggest them in order to the guidance of the most inexperienced culturist. In the preparation of ponds of this character it is not necessary that the drainage from the surrounding fields should be diverted, except when excessive in quantity or liable to become so after a heavy fall of rain. A certain amount of such drainage, indeed, often proves beneficial, as considerable quantities of food, generally of a very desirable nature, are thus conveyed into the ponds ; in the event of its being admitted, however, an "overflow" must be provided, which should be well protected by wire-cloth screens to prevent the escape of the fish. As this overflow constitutes the most important feature to be regarded in the construction of a pond, it is necessary that it be first and carefully considered.

For the purposes of illustration, there are shown in the accompanying plates the details of a pond which is supposed to be located in a meadow, through which flows a rivulet or small stream; and formed upon two sides, by embankments of earth obtained by the removal of a portion of the soil from the enclosed space. The water may be supplied either by introducing it from the rivulet itself, at some higher point; or, as in this illustration, from a spring in the adjacent meadow, supplemented by the surface drainage from the surrounding high land.

A small tributary of the rivulet is utilized in this instance to carry off the surplus water which is allowed to escape from the pond through the overflow indicated at the point $O$.

$A$, shows the apparatus for emptying the pond; the 
details of which will be given in another connection. $B$, indicates a frame, enclosing the end of the discharge pipe leading from the pond ; and provided with screens, $s . s . s$., the purpose of which will be indicated hereafter.

$C$, is the "collector," into which the fish are drawn by the lowering of the water in the pond; and $c$ a valve, which controls the flow of the water through the discharge pipe, $m$.

$D$, indicates the position and direction of a wide, shallow drain at the bottom of the pond; having smaller drains, $d . d$. d. $d$., by means of which all of the water is led into the collector when the pond is being emptied.

$E$, represents the embankments; which are about six feet in height at the angle of the pond, the lowest part of the meadow gradually lessening with the ascent of the land until they are lost in the higher ground.

In the next plate the upper portion presents a longitudinal section of the pond. The lower part of the plate shows a portion of the same section enlarged, so that with the horizontal projections the position and detail arrangements of the pond are clearly illustrated. The fish are readily drawn into the collector $C$. A long handle hook for removing the planks $g, g . g$, is shown at $h$.

As already stated, the "overflow," indicated at $O$, is perhaps the most important point to be considered, and especial attention is therefore directed to its construction. By way of precaution this outlet is located in the solid ground at the side of the pond, rather than in any part of the embankment, which might be weakened by its presence; and is protected by three wirecloth screens of varying texture, the coarser mesh being. placed farthest in the pond in order to collect all drift, and thus prevent the clogging of the second and third screens, the meshes of which should be fine enough to preclude the escape of the smallest fish. It will also be observed that the screens are so placed as to present a considerable 
surface below the water level-the purpose being to insure them against being clogged by the piling up of successive layers of drift, which otherwise would inevitably be occasioned by the gradual rise of the water consequent upon its obstructed flow. The arrangement suggested will always afford a free exit to the water beneath the mass of accumulated floating rubbish.

The general details of outlet, $A$, are clearly indicated in the views given. The screens s. $s . s$. -as well as those of the "overflow" - are disposed in a suitable frame work, and should slide easily in their respective grooves, so that they may be readily removed, cleaned and replaced. An additional set of such grooves are provided at this outlet, as will be seen by reference to the plate; and these latter. which are innermost in point of position, are furnished, instead of screens, with solid planks $g \cdot g \cdot g$. - the edges of which are neatly fitted to each other, so as to render their joints water tight, or as nearly so as possible. The upper edge of each plank, again is provided with staples or eyes- $f$. $f$. $f$. - througb which the hook, $h$, may be readily passed in order to lift the plank from the frame. When the planks are in position these eyes are received into corresponding slots, $n$. $n$., in the lower edge of the planks immediately above them, so as to allow the planks to fit closely together.

The purpose of this fourth, and solid, screen is to enable the culturist to lower the water in the pond, whenever it becomes necessary to do so, by drawing it from either the surface or the bottom, as may be deemed most advisable. To draw it from the surface only, it will simply be necessary to open the valve $c$; and to remove the planks in succession, as the water subsides. While to draw from the bottom will require all the planks to be first removed; and the valve to be opened when this has been done.

In addition to the valve $c$, the drain-pipe, $P$, may be provided, at $m$., with a clog or strainer, to guard it 
against the accmmulation of sediment or other obstructive matter.

The collectur. C : as is shown in the plates, should be placed at the lowest point in the pond: and, unless excarated in rery hard clay soil, shomid be both floored and faced with plank, cement or other hard material. The Carp, it will be remembered. have a strong tendency to bur themselves in the mud not only during their periods of semi-hibernation. but whenerer suddenly alarmed or closely pursued : and if the collector has been constructed as suggested. and the fish are gradually drawn into it with the subsicling water, all danger of loss on this account will be obriated.

The details of the "orertiow," "outlet," "collector," \&c., may. of course, be somewhat raried. according to circumstances: but the general requirements of a pond so located as to receive its supply of water at one end, and to discharge it at the other, are believed to be fully answered in the foregoing Rescription.

Ponds in this latitude should be not less than three feet in depth at their deepest part-to insure the fish against being frozen in severely cold weather-and should gradually shoal in places to a depth of one or two inches to proride the shallows required for spawning purposes. Small knolls and islands should be lerelled or removed, as they generally affor harboring places for the enemies of fish.

\section{Ponde ma Tidal Regions.}

It having been remarked in another connection that ponds formed by the reclamation of marshes in tidal regions might also prore well adapted to the cultivation of the Carp, the following suggestions are added with especial reference to the peculiar location of such ponds. The collector and drain ditches should be constructed and arranged in accordance with the instructions already given-the collector being formed, of course, at the lowest point within the embankment. 
The "overHow" may be omitted, if desired, as the "flume" can be readily adapted to the prurposes of carrying off any surplus water. As the flume, however, requires constant attention to insure its operation, the "overflow" should be retained, if practicable, in which event it is of even greater importance than in the case of the ponds already described that it should be placed in firm ground.

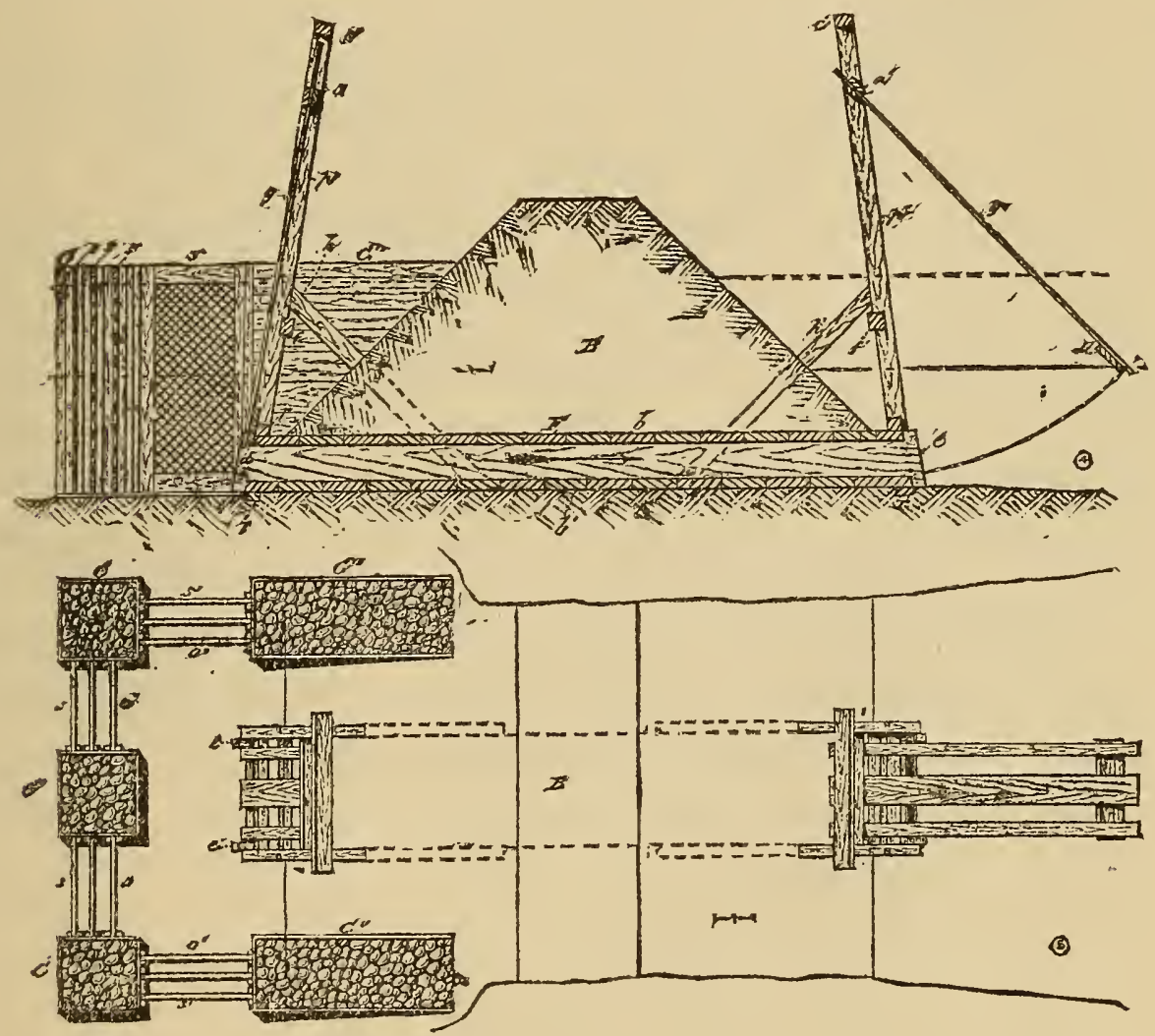

The acrompanying diagrams represent a vertical section, and corresponding horizontal projection of the embankment, $B$-showing the position of the flume, $F$, and its controlling valves, $d, d$; logether with that of the crib-work. " $C, C, C$, , which is constructed on the pond side, and is designed to support the screens emploved to prevent the escape of the Carp and the ingress of other fish.

'The flume is placer, as before, on a level with the bot- 
tom of the collector, and the valres are here shown as they appear when arranged for drawing the water from the pond, at ebb tide. The inner valve has been slightly raised. as will be observed, by stiding upward its support $g$ through the grooved trunnion $a$; and the pressure of the water flowing through the flume. in the direction indicated by the arrow; serves to suing open the outer ralve. and to keep it open until the pond is emptied or the tide turns. In the latter erent the outer valve closes automatically until the level of the water without again falls below that of the water remaining in the pond when its operation is resmmed.

Should it be desired, on the other hand, to admit water from the river into the pond-at the proper levels -the relative positions and operations of the valves would of course be rerersed. The onter ralve should then be raised so as to allow the water to enter the flume from the rirer: and the inner ralve should be lowered. in turn. to permit it to swing with the current. and to close automatically with the cessation of its flow.

The accompanying figures represent portions of the abore considerably enlarged for the purposes of a more detailed description of the several parts.

The flap ralre $d-$ which is here represented as being 

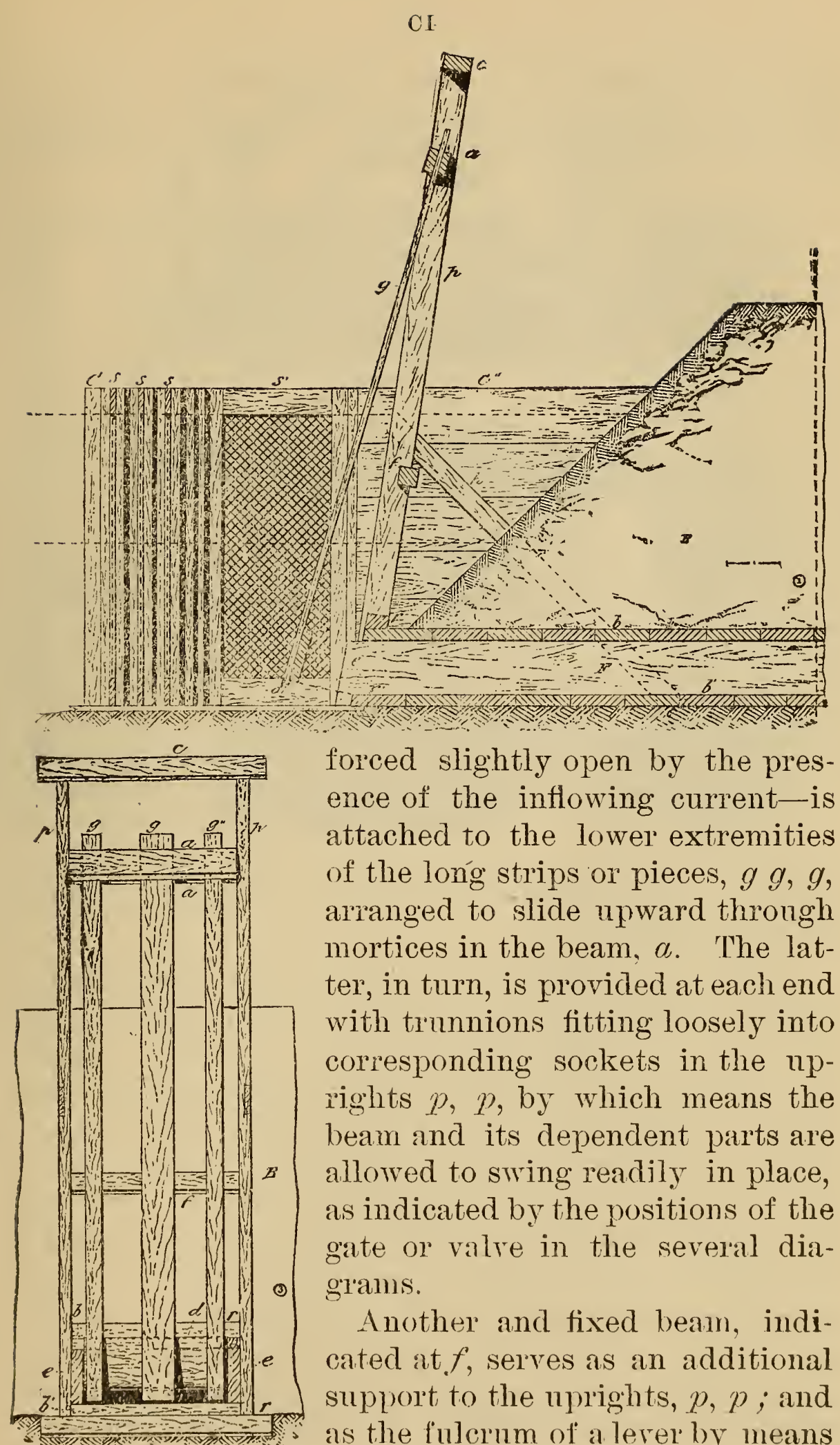

forced slightly open by the presence of the inflowing current-is attached to the lower extremities of the long strips or pieces, $g g, g$, arranged to slide upward throngh mortices in the beam, $a$. The latter, in turn, is provided at each end with trunnions fitting loosely into corresponding sockets in the upiights $p, p$, by which means the beam and its dependent parts are allowed to swing readily in place, as indicated by the positions of the gate or valve in the several diagrams.

Another and fixed bean, indicated at $f$, serves as an additional support to the uprights, $p, p$; and as the fulcrum of a lerer by means 
of which the gate may be raised or lowered. "C. $C, C$ " represent crib-work, filled with stones. and sustaining in position the screens $s, s$ and 0.0 . which are arranged

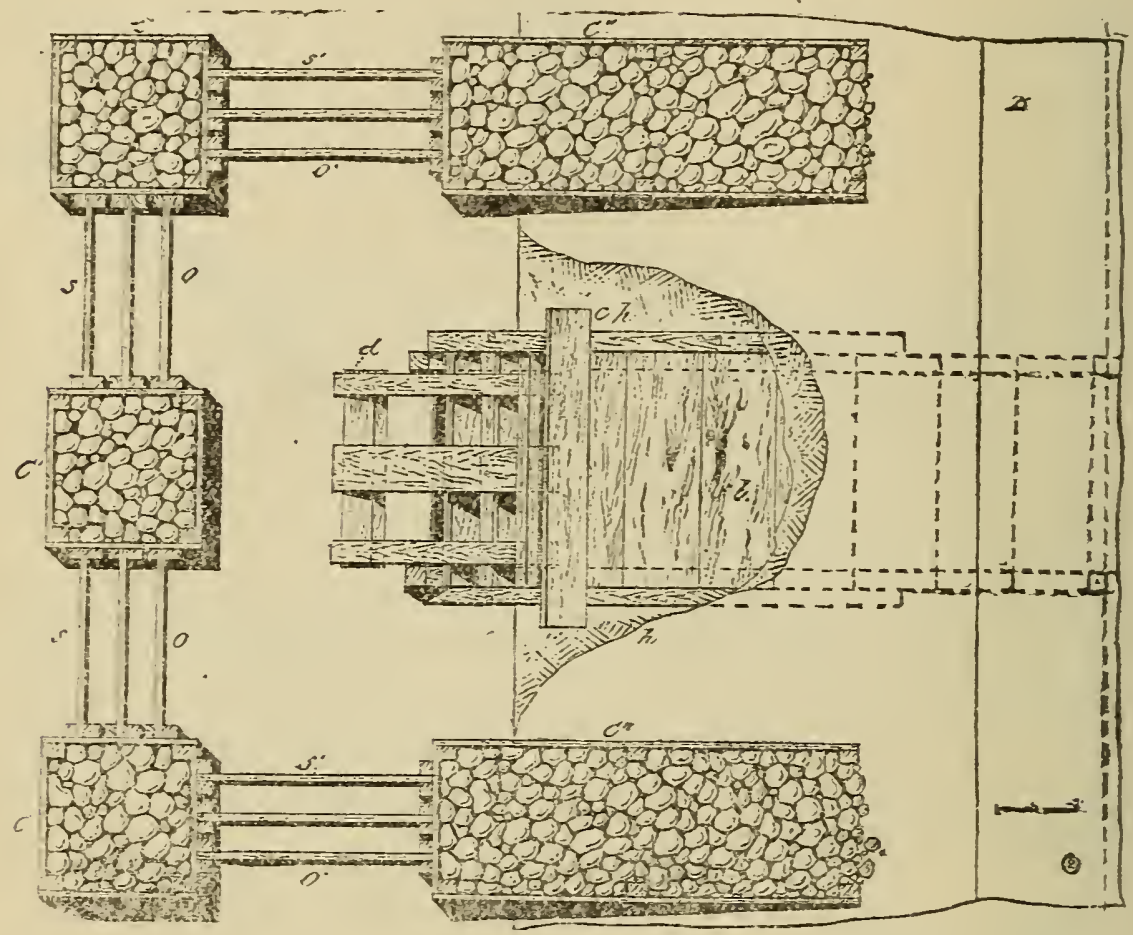

to slide in their respective gronves, similarly to those already described.

A flume or trunk of somewhat simpler and cheaper design: which may be constructed by hollowing out one side of a stout log, for nearly its entire length, and corering the groore thus formed with pieces of thick plank, is also figured; the bark should be allowed to remain undisturbed, where practicahle, for the sake of the protection which it affords to the wood. The general arrangement of the flume and its valres is so plainly indicated in the diagram as to render further description unnecessary; it will only be remarked. therefore, that as the valres do not work automatically: such a "plug-trunk" —as it is called-would appear to be better adapted for ponds located in other than tidal regions. 


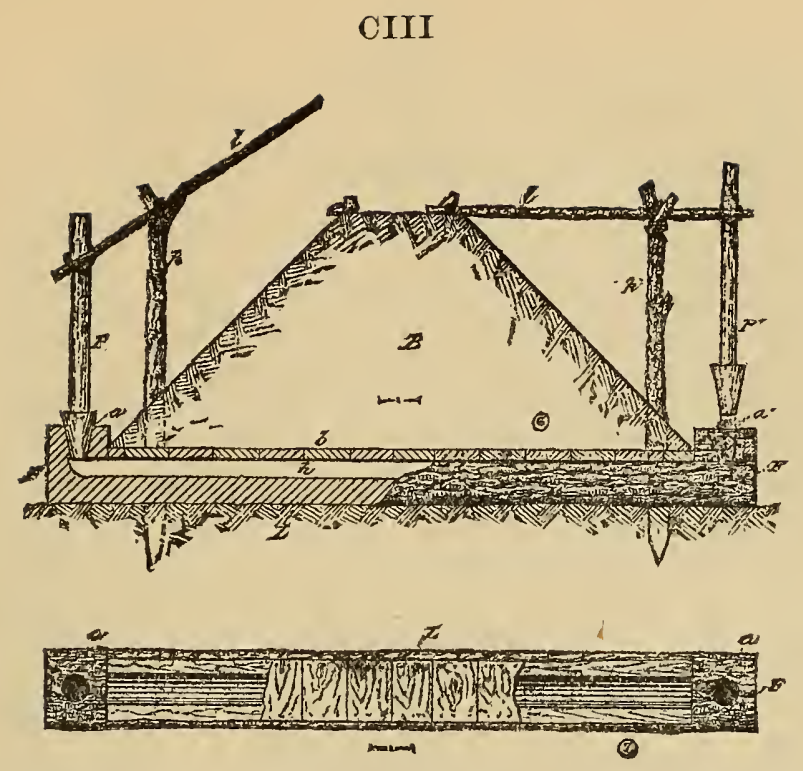

So much of the wood-work, in all these constructions, as may be exposed to the air, and, particularly, such parts as are subject to the alternate action of the air and. water, are liable to more or less rapid decay, and should be protected by thick coatings of paint, or other preservative material. Such other parts as are imbedded in the embankment, however, will be found to last for years. 


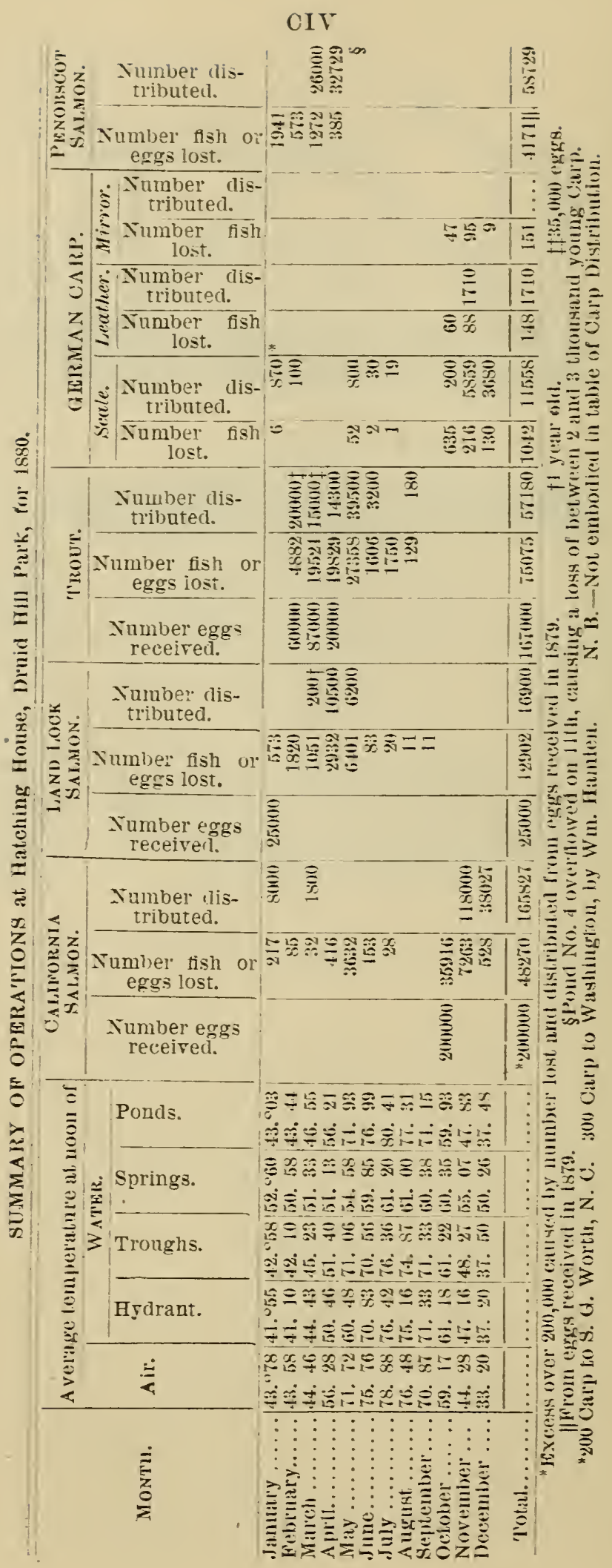




\section{$\mathrm{Cr}$ \\ OYsTER-(Ostrea virginiana.)}

In my last report submitted to the Legislature on the 1st of January, 1880, I explained how the consideration of the oyster beds and the study of this important mollusk had been forced upon the Commission, as a thorongh appreciation of the influences which bear upon the existence or non-existence, the increase or decrease of many of our important fishes, required some investigation as to the state of the oyster beds and the possibilities of employing means of continuing or restoring these beds, should they be destroyed by natural infinences or by the too extravagant and wanton use of them.

Whereas the investigation was commenced rather to ascertain the capacities of the oyster-beds for producing food for the more important fishes, the developments have been so important and the prospects so bright of increasing by artiticial means not only the number of oysters, but adding to their excellence by careful cultivation, I have prosecnted these researches to the fullest extent that the limited means at my disposal would permit.

It has been with much regret that the important experiments have of necessity been delayed and postponed from time to time, until by the practice of the closest economy in other branches of fish culture in the State a sufficient proportion of the portion of the appropriation assigned to me could be devoted to this purpose.

In consequence of the reduction of the amount arailable, the experiments have not been made on such a scale and with that thoroughness which I had hoped, nor have they been made as rapidly as their possible importance to the State would seem to demand. Enongh has been determined to warrant the prediction that the day is not far distant when oyster culture on the Chesapeake Bay will be one of the most prominent industries of the State.

Besides indicating how the oyster inciustry can best be fostered and guiding capital in its best investment, I 
trust that the accurate knowledge obtained from these investigations may direct legislation on this hitherto very vexed and intricate question.

In our last report we gave at length the article of Prof. W. K. Brooks, whose services had been secured for these biological investigations by the Commission, and we, al ' throngh the conrtesy of Mr. Carlisle P. Patterson, Superintendent of the Coast \& Geodetic Survey, made copious extracts from the report of Master Francis Winslow, as to the physical conditions and surroundings of the oysterbeds in Pokomoke and Tangier Sounds.

The researches and discoveries of Dr. Brooks indicated the possibility of resuscitating this important thongh waning industry of the State; but, unfortunately, Dr. Brooks was prevented from carrying his experiments to such a length as to determine the best methods of taking advantage of the discovery of the possibilities of the artificial impregnation and prodnction of the oyster.

The development of our oyster has been clearly marked and delineated in the report up to a state when it is a swimming animal and frequents the surface of the water. Unfortunately Dr. Brooks was not able to observe the continued development later than the sixth day, as the proper apparatus had not then been devised for the necessities of this serrice.

As this report contains some hints which may prove of much importance in the future, I take the liberty of again calling attention to them. Dr. Brooks says:

" $111 \mathrm{my}$ attempts to get later stages than these failed, " through my inability to find any way to change the "water" without losing the young oyster, and I am there"fore unable to describe the manner in which the swim" ming embryo becomes converted into the adult, but I "hope that this gap will be filled, either by future "observations of my own or by those of some other em"bryologist.

"In my attempt to raise the oyster embryo from the 
" egg, I found that continuous warm weather was essen"tial to success. As my observations upon the devel" oping eggs occupied all my time, I was not able to " make any record of the temperature of the water of "the ocean, but during June there were a number of "cold, windy days and nights, and two hail-storms, and " on each of the cold days all the embryo which I had in the house died.

"At first sight it does not seem possible that an ani" mal which is encased in a hard, strong, protecting "shell, and which is capable of giving rise to several "million eggs every season, can be in any danger of " extermination; and it seems as if the oyster ought to " be able to hold its own in the struggle for existence, " and to increase and multiply in the face of the most "adverse circumstances.

"It appears wonderful that the waters of the Chesa"peake Bay are not paved with oysters, and persons " who have not given much thought to the subject will "ridicule the statement that there is any need for meas" "ures to prevent their extermination or the destruction " of the natural beds. While the consumption of oys" ters was restricted to regions in the immediate vicinity "of the beds, the number of oysters which it would pay "to gather and put into the market each season from " each bed was limited; but with the present facilities " for packing and transporting oysters, there is no limit "to the number which can be utilized, and the danger " of destroying the best beds grows greater every day, "and keeps pace with the increasing population and "improvements in transportation."

After giving some statistics of the catch of oysters in the Bay of Cancale, Dr. Brooks further remarks:

"The table also shows that it will not answer to rely "upon the very great number of eggs, and therefore "trust to a few oysters the work of replenishing the "bed. 
"In view of such facts, no one who appreciates the "magnitude of the oyster industry of the Chesapeake "can doubt that the protection of the natural oyster "beds is a matter" which is worthy of the most careful "attention. While the manner in which this is to be "accomplished is ontside the scope of the present paper, "a statement of those farorable and unfavorable influ"ences which have suggested themselves to me during " my work, may fairly find a place here.

"It is well known to naturalists that the number of "individuals which reach maturity in any species of "animals or plants does not depend upon the number "which are born. The common tape-worm lays hun"dreds of millions of egg's in a rery short time, vet it is "comparatively rare. The number of children born to " each pair of human beings during their lifetime of from "fifty to eighty year's, can be counted on the fingers, yet "man is the most abundant of the larger mammals, and "human population increases quite rapidly under favor"able circumstances. This comparison shows plainly "that the abundance of a species is determined, mainly, "by the external conditions to which it is exposed, and "that the number of individuals which are bor"n has "rery little to do with it. In the case of the orster, the "adult is well protected against enemies by the shell, "and as its food is abundant, and is brought to it by "the water. it is tolerably sure of a long" life after" it has "reached its adult form. but the life of the young is "very precarious; that of the young" American oyster "peculiarly so, since it is exposed to all kinds of ene"mies and accidents, at a time when it is most helpless.

"The protection of the young European oyster by the "parent shell at this time would seem to more than bal"ance the greater number of eggs laid by the American. "The most critical time in the life of the American "orster is undonbtedly the time when the egg is dis"charged into the water to be fertilized, for the chance 
" that each egg which floats out into the ocean to shift " for itself will immediately meet with a male cell is very "slight, and it is essestial that the egg should be fertil"ized very quickly, for the unfertilized egg is destroyed "by the sea water in a very short time. The next period " of great danger is the short time during which the " embryos swarm to the surface of the water. They are "so perfectly defenceless, and so crowded together close "to the surface, that a small fish, swimming along with "open mouth, might easily swallow in a few mouthfulls "a number equal to the human population of Baltimore. "They are also exposed to sudden changes of tempera"ture, and as my experiments have shown that a sudden "fall in temperature is fatal to them at this time, the " number which are destroyed by cold rains and winds " must be very great indeed.

"As soon as they are safely past this stage, and scatter " and swim at various depths, their danger from accidents "and enemies is greatly diminished, and their chance of "reaching maturity increases hundreds, and probably " thousands of times.

"My experiments snow that there is no difficulty in " developing them up to this point in the house in small "aquaria, and in carrying them safely past the most "precarious part of their lives, and freeing them from "all their greatest dangers."

The importance of carrying the investigations beyond the point reached by Dr. Brooks, induced me to secure the services of Professor John A. Ryder, of the Philadelphia Academy of Sciences, and having provided quite an assortment of collectors, I stationed him in the month of July at the month of the south fork of St. Jerome's Creek, in St. Mary's County. 'This creek Hows into the Chesapeake a few miles north of Point Lookout.

Having secured the use of ponds, formed by a prong of this creek, it was my intention to arrange them so as thoroughly to control the ebb and flow of the tide 
and the inflow of fresh water from the drainage of the land adjacent, by providing embankments, flood-gates, and waste-ways; but the unexpected diversion of a large portion of the appropriation prevented my carrying into effect these plans, so important for an exhaustive study of the subject.

In order to enable Prof. Ryder to carry on his experiments in a thorough and systematic manner, it was essential that a limited body of water should be isolated from the creek and the water be under complete control. It was important, also, that means should be provided that the enemies of the young oyster, as far as practicable, shonld be excluded.

Crude and imperfect as were the means available, Prof. Ryder pursued the line of investigations with important results, although he experienced the same difficulty in keeping the young oyster as did Dr. Brooks.

He was enabled during his stay at St. Jerome's to determine with some accuracy the rate of growth of the "spat" and to make very important researches as to the food and manner of fattening the oyster.

Prof. Ryder's report, which is full of interest, will be found in the appendix, and its careful perusal is earnestly recommended, as his cautious utterances should guide us to the future solution of this important question.

As soon as it can be done without detriment to the other important branches of fish culture, I trust that, with the additional light which has been shed upon this subject, I shall be able to provide Prof. Ryder with proper apparatus for the prosecution of these important investigations, for I am quite satisfied that as soon as we are able to artificially produce the oyster and protect the young until it finally attaches itself to some stationary object, we will have certain means of multiplying this bivalve to an unlimited extent and of furnishing it for planting purposes at less cost than can now be done by the dredging process. We will also be able with cer- 
tainty to replenish beds which have been so far exhausted as to have lost, to a great extent, the power of reproduction in themselves, and to establish new beds in localities where the oyster does not now exist.

I trust that the experiments made and to be hereafter conducted, will enable us to determine the best form of collector to be used in our waters and the best manner in which it shomld be treated and the attached young oyster cared for.

The importance of the discoveries as to the means of artificial propagation of the oyster can be appreciated when we take into consideration the fact, that the soils and localities which are favorable for the reproduction of oysters are not always favorable for their subsequent development, as there are many places where oysters thrive but where they will not breed, it being generally accepted that the best conditions for propagation are sandy and gravelly bottoms and quite salt water, whereas muddy bottoms and a mixture of fresh water are most favorable for fattening.

The many conditions which influence the breeding, growth and development of the oyster--that is the soil, temperature, sudden alternation of heat and cold. direction of current, the occurrence of very low water at periods of extreme heat or extreme cold, and many other natural conditions, all indicate the importance of establishing now the artificial propagation of the oyster, notwithstanding its wonderful reproductive capabilities.

The importance of the oyster of the Chesapeake Bay can be appreciated by a pernsal of the following figures, which I have obtained through the courtesy of Professor G. Brown Goode, Superintendent in charge of the fishery statistics of the census of 1880 : 


\begin{tabular}{|c|c|c|c|c|c|}
\hline \multicolumn{6}{|c|}{ OYSTER WORK IN } \\
\hline $\begin{array}{c}\text { KIND OF BOAT } \\
\text { EMPLOYED. }\end{array}$ & $\begin{array}{c}\text { N U M - } \\
\text { BER. }\end{array}$ & $\begin{array}{l}\text { VALUE OF } \\
\text { BOAT } \\
\text { AND } \\
\text { EQUIPMENT. }\end{array}$ & $\begin{array}{l}\text { No. } \\
\text { MEN } \\
\text { EM- } \\
\text { PLOYED. }\end{array}$ & $\begin{array}{l}\text { WAGES OF } \\
\text { SAME. }\end{array}$ & $\begin{array}{c}\text { NO. } \\
\text { PEOPLE } \\
\text { SUPPOR- } \\
\text { THD BY } \\
\text { OYSTER } \\
\text { CATCH'G. }\end{array}$ \\
\hline $\begin{array}{l}\text { Dredgers } \\
\text { outfit of same } \\
\text { Scrapers } \\
\text { Canoes } \\
\text { Runners }\end{array}$ & $\begin{array}{r}700 \\
550 \\
1,825 \\
200\end{array}$ & $\begin{array}{r}\$ 1,050,000 \\
70,000 \\
440,000 \\
182,500 \\
300,000\end{array}$ & $\begin{array}{r}5,600 \\
2,200 \\
5,148 \\
800\end{array}$ & $\begin{array}{r}297,000 \\
1,158,300 \\
166,400\end{array}$ & \\
\hline Runners & 3,275 & $\$ 2,042,5(0)$ & 13,748 & $\$ 2,538,000$ & 54,992 \\
\hline
\end{tabular}

NuMBer OF OYsTers Taken 1879-80. . Bushels. No. packed in State-of Md. oysters............ 6,653,492 “ shipped ont of State......................... 2,021,840 Local consumption in Baltimore................ 818,680 " " other cities of the State... 200,000 " " counties ..................... 875,000

$10,569,012$

It will be seen that in the year 1879 to 1880 , there.were 13,748 of our citizens employed in catching and bringing to market the ten and a half million of bushels produced; and when we take this into consideration and the amount of capital consumed in preserving and exporting the oyster, the importance of providing for a continued supply is most evident.

The Chesapeake Bay, situated, as it is, between the colder water's of the north and the warmer southern zone, is unexceptionally suited for the cultivation of the oyster, its reproduction, growth and fattening, as it is not exposed to those vicissitudes of temperature which so frequently prove fatal; and the limited average in the rise and fall of the tide renders the existence of the oyster: in shoal waters less precarious and their protection far less expensive than it has proved on the coast of France, where the oyster-growing industry has added new life 
and prosperity to portions of the coast which were fast becoming impoverished.

The facility for working the oyster parks at low tide in localities where there is a very great rise and fall of tide, is more than neutralized by the costly arrangements which must be devised for keeping them sufficiently covered to prevent their exposure to destruction, which would be the result were they laid bare at critical peri. ods; yet, although oyster culture has hardly existed a decade, the promises of success have been more than realized, and results have been obtained by the employment of methods so simple, that the proprietor of any oyster establishment will readily undertake to supply millions of oysters to any one wishing to enter upon their cultivation.

When we have ascertained with precision the period of attachment, when the spat forsakes its roving existence for a settled life, and have demonstrated that the oyster can be produced in unlimited numbers and successfully protected until this attachment is made, we will have gone far beyond those methods which have produced such good results in European countries, and it will be then necessary to take advantage of their experiences for the determination of the best form of collectors and the subsequent treatment of the oyster until it is sent in a perfect state to market.

It may, therefore, be more appropriate to reserve for a future report the details as to the form of collectors, information which I obtained during a recent examination of the typical oyster cultural farms of France. The determination of the form of collector best suited for the several localities of the Chesapeake Bay must be determined by actual experiment with the chaplet, (collector formed of shells strung on galvanized wire,) the favorite in the Bay of Arcachon; the bouquet, (collector formed of twelve tiles secured around a stake which hold them in position, ) a form much used in the neighborhood 
of Vanne and Auray; the shingle, slate, brush, pottery and other forms of collectors, severally the favorites in various localities.

Having advanced thus far in our experiments, it would be well for us to follow the methods of treatment and preparation of the oyster in practice at Courseulles, Les Sables D'Oleron and Marennes, where the energy of the culturalist is devoted to the fattening of the oyster for market.

The oyster industry forms too considerable a portion of the wealth of the Chesapeake Bay and is of too much commercial value to be allowed to suffer decline.

I trust that we may be enabled to prosecute our inquiries so as to present to the consideration of the Legislature the unanswerable logic of facts and suggest the methods of protection and devise means for continuing an ample supply of a great blessing which, although lavishly enjoyed, has scarcely been fully appreciated.

It is to be feared that much of the previous legislation has been ineffective, as based on evidence defective and misleading in its character, the result of misstatements and convictions formed by conflicting advice given by interested persons or by those misguided by too imperfect observation.

Respectfully submitted,

T. B. FERGUSON,

Commissioner. 


\section{A P P E N DIX A.}

AN ACCOUNT

$\mathrm{OF}$

\section{Exprerimenty in (1) Duter $\mathbb{C}$ Culture}

AND

\section{OBSERVATIONS RELATING THERETO,}

Made at St. Ferome's Creek, Md., during the Summer of 1880 ,

$$
\text { BY }
$$

JOHN A. RYDER. 



\section{INTRODUCTORY.}

On the 18th of July last, Maj. T. B. Ferguson, Commissioner, having completed the preliminary arrangements looking forward to the establishment of an experimental station where every opportunity should be offered for the cultivation of the oyster by artificial means, employed the writer to carry on the necessary work of experiment and observation. The locality chosen for our operations by the Commissioner, was about seven miles north of the mouth of the Potomac River, on the western shore of the Chesapeake Bay, in St. Mary's Co., Md., and forms part of an inlet extending several miles inland, known as St. Jerome's Creek. Here, a pond, covering an area of perhaps two or three acres, which is joined to the main body of the creek by a narrow run or canal, through which the tide ebbs and flows, was chosen with the design of converting it into a claire or oyster park, somewhat similar to those in successful operation on the coast of France. The pond having been leased from the owner, Mr. J. W. Wrightson, for a term of years, with the privilege of making such improvements as might be necessary in carrying on the work of oyster culture, presents, in all respects, as favorable a situation in the opinion of the writer, for the purpose intended, as could be desired.

After some delay in getting our work agoing, we succeeded however, in obtaining some results and many experiences, which will be of great use in guiding us to the attainment of better results in the future. My object, in the main, was to learn what were the difficulties which would beset us in our future work and to find out what methods might suggest themselves as better calculated to further our efforts next season. The time of breeding 
was already nearly half over when our work began, and to this, as much as to anything, the comparative unsatisfactoriness of our results must be attributed. While we are forced to admit so much, a large amount of valuable information has been gathered, a good deal of which is entirely new to science and very suggestlve as to what will be the proper paths to follow hereafter in the conduct of the work.

We have devoted a considerable amount of space to an account of the structure of the oyster, with illustrations, so as to make it easier for the anatomy and physiology of the animal to be understood by persons not familiar or within reach of the treatises on the subject. The idea has not been, to tacitly imply that the account given by Prof. Brooks in last year's report was not a good one, but simply to illustrate pictorially, as far as lay in my power, the grosser anatomy of the creature, so as to enable a novice to find the ovaries and spermaries of the animals more readily if it should be desired to impregnate the eggs artificially, either for the sake of experiment or artificial culture.

The numerous suggestions which have been made throughout the body of the text as to the extension of the banks and the possible practicability of entirely new plans of culture will, I hope, be found of value. The matters of mere scientific record and observation are such as would have been noted by any observer, endowed with a fair share of common sense and having a naturalist's training.

The appended observations on the artificial impregnation of the European oyster made by Francis Winslow, U. S. N., are important, as showing how closely parallel the phenomena of development in this species are to those of our own. I place entire confidence in these observations, as they are fully supported by what was previously known of their development through the research- 
es of Davaine, Salensky and others, who, however, have failed to see the earliest stages.

The note on the development of Mya arenaria is added merely to establish the time of the spawning season; to show that it is possible to impregnate the eggs artificially, and to indicate to some extent the nature of the process of development, the study of which I could not complete owing to illness.

The histology of the ovaries of both the oyster and clam remains to be studied, since it is possible only by that means to ascertain whether the whole of the eggs are mature at one time. The researches of Flemming and Von Jhering show that such is not the case in Unio and Scrobicularia. Much of the success of future attempts at artificial incubation depends upon a decisive answer to this question. My own experience in investigating the ovaries of Ostrea and Myo, countenances the belief in my mind, that the time of maturity for nearly all the ovarian eggs is about the same.

The question as to the exact age of the fry of the oyster at the time of fixation, as well as the age of the fry of $M y a$ at the time it buries itself in the sand, also awaits an answer; but it is the hope of the writer that, with an incubating apparatus which he has lately devised as an adjunct to his microscope, he may in the course of another season's work, reach a satisfactory conclusion in regard to this, as well as many other important matters. 


\section{ANATOMY OF THE OYSTER.}

THE SHELL.

In view of the fact that the structure of the American oyster has hitherto excited comparatively little attention, we offer here the results of investigations made upon thirty-seven specimens. The best account which is known to me, and one accompanied with a good figure, is that given by H. James Clark*, and which anticipates in many respects, a note contributed by the writer to the American Naturalist for September. 1880. Another admirable account of the structure of this mollusc has been given by Prof. W. K. Brookst, but after comparison, I find that my observations are not wholly in accord with the accounts of either of these careful observers.

In Fig. I, I have attempted to represent in a somewhat diagrammatic manner the structure of the animal under consideration, with indications of some of its physiological or animal processes, such as the inhalation and exhalation of water for breathing purposes, and the manner in which the food is carried to the month to be swallowed.

The oyster always presents a definite right and left side, and the two shells or valves which enclose the animal, always differ in that the left one is more deeply concave or hollowed out than the right, which is nearly flat. In the natural beds the left valve is usually, if not always undermost, but in the crowded banks the animal usually assumes a vertical position, a condition which does not, however, affect this unlikeness of the valves. In the figure, the left valve has been removed, the animal of the oyster is shown lying in the more shallow right. The head end of the animal lies close against the

Mind in Nature. New York, 1865. pp. 199-203.

+Report of the Maryland Commissioners of Fisheries, 1880. pp. 5-1o. 


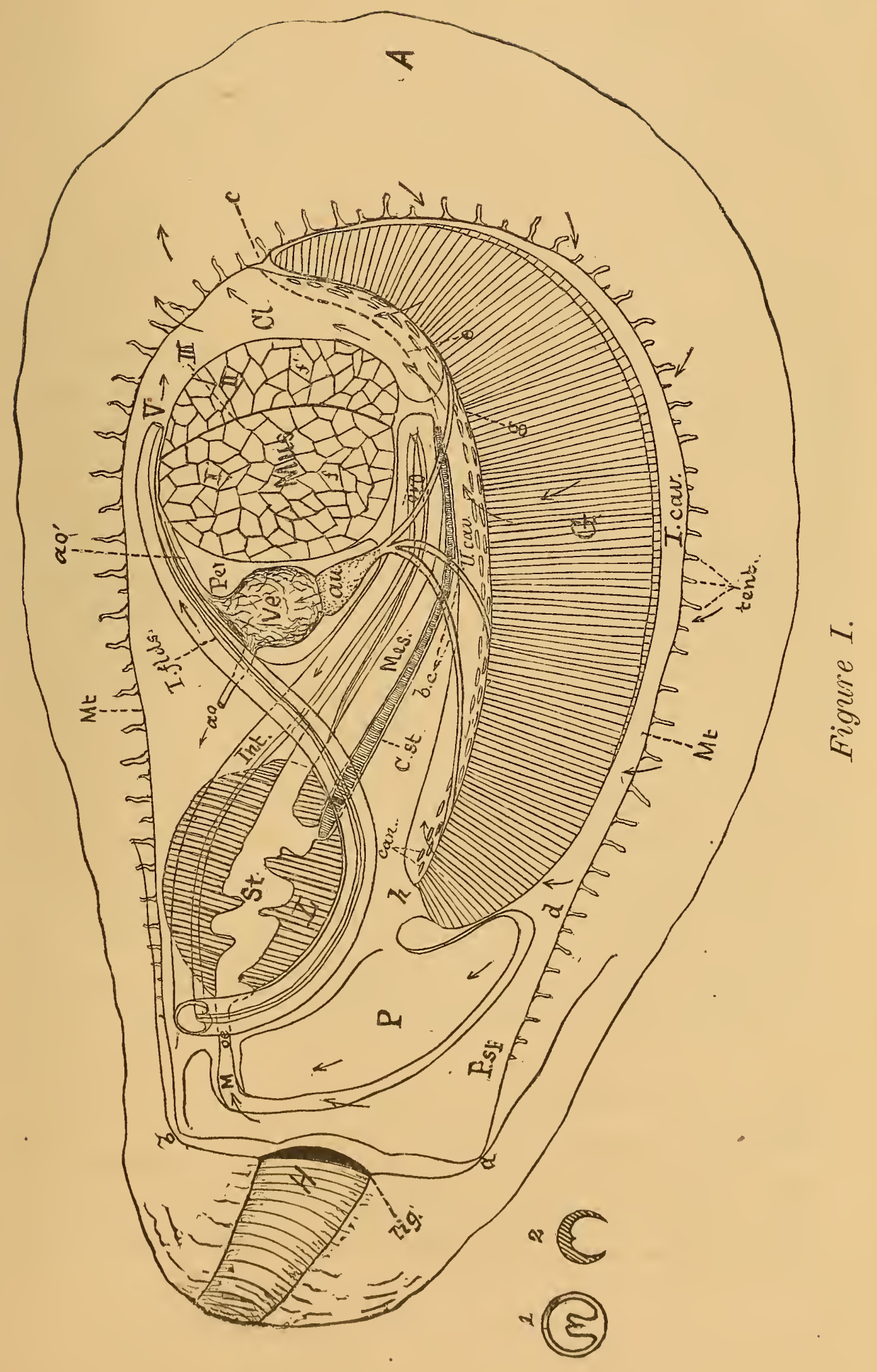



hinge $H$, or the point where the two valves are firmly fixed to each other by a dark brown crescent-shaped body, the ligament lig., which, while it serves to attach, also tends by reason of its elastic properties to cause the valves to separate at their free borders at $A$, in order to allow the passage of water inwards to the gills $G$, and of food to the mouth $M$, while it also allows the water which has passed through the gills to escape by way of the cloaca $C l$, carrying with it in its passage the faeces from the vent $V$. The tendency to separate the valves, inherent in the ligament, is balanced by the adductor muscle $M u s$, which, upon the slightest intimation of danger, forcibly contracts, closing the free edges of the valves tightly. The dark purple scars near the centres of both valves, and vulgarly known as indicating the position of the "heart," are simply the areas covered by the attachment of this adductor muscle, which is composed of a vast number of extremely fine muscular fibers, which collectively pass straight across the space between the inside of the valves, being firmly fixed at either end to the latter. The muscle, when closely examined, is seen to be composed of bundles of fibers or fibrillie, which may be called fibrils, each with its proper sheath, and polygonal in cross-section. The muscle is also made up of two kinds of fibers, the larger portion, embraced in the area I, are brownish gray, while those in the smaller area II are whitish ; the line of contact between the two is sharply defined by the curved line III, where they are also easily separated as portions of a compound muscle. The foregoing fairly describes the mechanism of the shell, and in part the physiological significance of the same.

The structure of the shell is laminar, or in other words, it is composed of numerous layers of carbonate of lime deposited one on the other by the mantle (the latter to be described farther on, probably from the blood or possibly in some other way. These layers de- 
posited as they are internally. as growth proceeds project in succession past each other at the free edges of the ralres and external surface of the shell. so that the successire deposits may frequently be distinguished. espeperially, as these deposits seem to be laid down periodicalls. giving rise to a rery rough imbricated appearance of the edges of the layers on the outside of the shell. The inner pearly or nacreous layers of the shell are different in structure from the onter ones. These are made up of microscopic prisms of carbonate of lime embedded in a matrix of horny substance, analogous. if not identical with the substance which forms the external hard parts of insects The outer portion of the shell. forming much the largest proportion of the whole. is differently constituted according to Nathusius-Königsborn". who finds that in the shells of the oyster of Europe there are superimposed cavities. filled in life with water, which lie just beneath the inner pearly layers and between the attachment of the muscle and the hinge corresponding to the thickened nacreous portion. In the thick marginal portion of the shell, extending from a point half way between the insertion of the muscle and hinge. to near the edge of the ralres, he finds still another series of closed cavities which are separated by oblique divisions of a laminar character, and which are tilled with a singular structure of minute cavities which contain air. The first kind or the water bearing carities are, it may be well to remark, greatly dereloped in spondylus. an ally of the orster. The laminar character of the shell is apparent from the presence of rery tine lines of growth even on the valves of the free-swimming embryos. and in the embryonic shell which covers like a little raised cap the extreme tips of the umbos or hinge ends of the valres of attached spat $\frac{1}{\ddagger}$ to 1 inch in diameter.

During the past season I endearored to ascertain if it

* Cntersuchungen ueber nicht cellul re Organismen, namentlich; Crustaceen-panzer. Mollusken-Schalen und Eihellen.- Von W. Ton Vathusius-Kinigsborn. 4 to., pp. I44, pls. I6.
Berlin, I $\varepsilon_{7 \%}$. 
was not possible to determine the age of marketable oysters from what appeared to be annual arrests of growth, indicated on the ontside of the shell by deeply impressed lines or projecting laminae placed at nearly equal distances apart, but I failed, after examining a great number of living and dead shells, to arrive at any satistactory conclusion.

\section{THE ANIMAL。}

In Fig. I the head of the animal lies directed towards $H$; the tail end, on the other hand, lies towards $A$; the back or upper side of the animal extends from $b$ to $c$; the ventral or lower side reaches from $c$ to $\alpha$ up to the mouth $M$. The right and left sides of the animal are covered by an organ called the mantle $M t$. Mt.; it is not attached to the shell anywhere except around the points where the ends of the adductor muscle, Mus, are fixed to the valves of either side. This organ encloses, like a curtain, the internal organs of the creature on either side, and lies next to the shell, and secretes and deposits the layers of carbonate of lime composing the latter. The free edges of the mantle, which are purplish, are garnished with small, highly sensitive tentacles tent. of the same color, and which serve the purpose of organs of touch and are perhaps also to some extent sensitive to light. The borders of the right and left folds of the mantle are free from $b$ to $c$, where they nnite, and from $c$ to $a$, but from $a$ to $b$ they are joined together. In the space between the right and left folds of the mantle from $b$, $a$ to $d$, the palps $P$, or lips of the oyster, are included; this cavity may be called the palpal space $P$. sp. The palpal space is continuous with the inferior gill cavity $I$. cav., from $d$ to $c$; in this space, bounded like the latter on each side by the mantle, the four leaf-like branchiae or gills $G$ hang suspended by a membrane, which unites with the mantle on either side along the line $e$; this membrane, together with the bases of the gills, forms a cavity limited below by the upper edges of the gills at $g$ 
and above by the viscera along the line below $C$. st., the mesosoma mes. or lower middle portion of the body and the adductor muscle; this upper gill cavity $U$ cav., extends from $h$ to $c$ and is continuous with the cloaca $C l$, which is the space between the upper free folds of the mantle from $b$ to $c$.

The physiological significance of this arrangement of parts will be understood by noting the directions in which the arrows are supposed to be moving. As the living oyster lies fixed at the bottom of the water with the free edges $A$ of the valves slightly separated, the minute cilia or hair-like processes with which the gills and palps are covered, are constantly in rapid vibratory motion; this peculiar movement over the gills and palps causes a current of water to travel from without into the inferior gill civity I. cav., a part of which passes on to be carried by the cilia of the palps towards the mouth for the sake of the microscopic food it may contain in suspension; after this has been gleaned out, the water probably passes back to the inferior gill-cavity between the pendulous lobes of the outer and inner pairs of palps. The fate of the water which passes through the gills is entirely different, though the gills seem to take part in carrying food towards the palps and mouth, a phenomenon which may be readily rendered apparent to the eye by scattering powdered cochineal or fine meal on the gills or palps, when it will be seen that the motion of the cilia on both organs causes the particles to move with considerable rapidity towards the mouth. The water passes up between the leaves of the gills, actuated by ciliary motion, and enters the npper gill cavity through a large number of openings or canals between the gills can. and passes out towards the cloaca $C l$,into which the vent $V$ also discharges its excreta, and is so carried out of the animal back into the surrounding water. The whole of the process of respiration or aeration of the blood appears to be effected in the gills proper. 
The transversely elongated mouth $M$. of the oyster lies between the upper bends of the palps, it is followed by a very short gullet or oesophagus oe, which opens into tne stomach St, the walls of which are very much folded and wrinkled, the folds often dip into the substance of the massive brownish green liver $L$. and give entrance to the numerous and spacious bile ducts of the latter. At the hinder end of the stomach one of the deep folds appears to be continued backwards in the form of a blind, cylindrical pouch to or beyond and between the openings of the oviducts of either side; this pouch contains a transparent, but at the same time opalescent rod, the so-called crystalline style $C s t$, the function of which is not known. The intestine as it first leaves the stomach proper is somewhat wider than at other points, but I do not know why Prof. H. J. Clark considered this portion, as far back as the first bend, part of the stomach. It seems to me that the irregular digestive cavity enclosed in the liver-mass should be regarded as the stomach, because the first portion of the intestine already contains the commencement of a peculiar pair of folds running lengthwise, which will be spoken of later. Returning to the course of the intestine Int, after passing backwards beneath the adductor muscle, into the mesosomal or middle part of the body, when it suddenly bends and is prolonged toward the head, passing a little to the right of the stomach and along the back of the animal, when it again suddenly turns to the left and crossing the gullet $o e$, descends in a gentle curve along the left, lower side of the body, passing obliquely upwards over the pericardial space Per, which contains the heart, to end in the anal opening at $V$. A peculiar double fold, $I$. $f l d s$, which projects into the intestinal cavity, extends from the pyloric end of the intestine to the vent; its function is probably to afford a greater amount of surface for the absorption of nutriment, or it may be valvular in character. The greater portion of the inner intestinal surfaces 
are probably covered with cilia in more or less active motion, for all the portions of the lining of the stomach and intestine examined by me appeared to be provided with a ciliary covering. The faeces of the oyster are not extruded in the form of a cylinder as in many other mollusks, but have the form of a demicylinder with one side excavated in a groove-like manner, as shown in section in Fig. I, 2, the peculiar form being due to the presence of the longitudinal folds in the intestine, as shown in a cross-section of the latter in Fig. I, 1 . In Unio, the fresh-water mussel, a similar arrangement is said to exist, according to Bronn; (Klass. u. Ord. des Theirreichs. III, p. 364.)

The conrse of the intestine as sketched above is most nearly in accord with Clark's account; the figures given by Sir Everard Home* of the intestine of Ostrea edulis are also in close agreement, but the proper relation of the mouth and palps was evidently not understood. Home's figure, however, fully justities, with other evidence, the criticism made in Woodward's Manual of the Mollusca, regarding the inaccuracy of Poli' st figures of the same parts.

The systemic heart is that organ -which serves to propel and continually redistribute the colorless blood of the oyster throngh the body for its nourishment, and through the gills that the blood itself may discharge into the water the poisonous gases with which it is loaded in passing through the body, and receive a fresh supply of oxygen as fresh supplies of water pass through the gills. The heart consists of three chambers; the upper and largest is the ventricle ve, and the two smaller, lowermost, brownish, paired chambers are called auricles $a u$; the three chambers lie in a crescent-shaped space, the pericardial space Per, just forward of the adductor muscle. The ventricle ve, is almost globular;

*Philos. Trans. 1827. pl. IV.

†Testacea Utriusque Siciliae eorumque Historia et Aratome, II. Tab. XXIX, fig. 3. Parma, I795, Fol. 
its walls are made up of a delicate meshwork of muscular fibers so interlaced as to be altogether untraceable; by its contractions it forces the oxygenated blood fresh from the gills to all parts of the body through two large vessels, or properly, aortae, the first, ao, supplying the forepart of the body, and $\alpha o^{\prime}$ the hinder portion. These larger vessels divide into smaller ones which effect the distribution of the blood towards the head, and through the viscera, where, as in other parts of the body, a network of fine capillary vessels exists. The blood accumulates perhaps in sinuses, one of which is the pericardial space, and there are besides probably a pair of rudimentary ones in the oyster, the vestibule of a rudimentary organ of Bojanus, from these, through the venous system of vessels, the blood is carried back to the gills to be aerated, and returned through the vessels which carry the blood from the gills to the auricles, the branchiocardiac vessels $b c$. Of the last, there are three on each side of the oyster, two pairs of which collect the blood from the forepart of the gills, and one pair of which gather the blood from the posteriar portion of the gills to be carried to the auricles, from whence it enters the ventricle, having completed its circulation through the whole vascular system.

It is frequently noticed that the edges or a considerable part of the mantle of the oyster is very much swollen and nearly transparent, as though greatly distended with water; this is due to a peculiar arrangement of capillary vessels connected with the blood-system which causes the blood to be held in these places until turgescence is produced as in erectile tissues. The presence of an unusual amount of water in the blood no doubt sometimes helps to produce this last effect, since the blood-system is probably in communication with the water outside, through the openings from without into the organ of Bojanus, a part which answers to the kidney in other bivalve mollusks, but which seems to be 
very rudimentary in the oyster. When oysters are removed from salt water to that which is less salt, a similar enlargement of the animal takes place, which may be entirely attributed to the effect of the action of the well-known laws of osmosis, and should not be regarded as a fattening process at all, since the real "fat" of the oyster is something vastly more substantial than water, as will be learned in the sequel. Prof. P. Frazer, Jr., * has discussed the subject of fattening oysters by means of osmosis.

For my own part I believe that the turgid, translucent appearance of the edges of the mantle in the oyster is due to the passage inwards of water through the mouths of numerous vessels which open freely on its surface; these from my microscopic examinations seemed to be the extremities of the capillaries of the mantle, and I find that for this belief I have the concurrent testimony of other writers, (Bronn; Klass. u. Ord. III, 384.)

The nervous system of the oyster is very simple, being composed of a pair of ganglia or masses of nervous matter, which lie just over the gullet, and from which a pair of nerve cords pass backwards, one on each side, to join the hinder pair which lie just beneath the adductor muscle. The mantle receives nerve branches from the hindmost ganglia, and these control the contraction and elongation of the radiating bundles of muscular fibers as well as those which lie lengthwise along the margin; the former contract and withdraw the edges of the mantle from the margin of the shell, while the latter in contracting tend to crimp or fold its edges. The tentacles, or organs of touch, are also mainly supplied from the hindmost ganglia, while the internal organs are innervated from the head ganglia.

*On Dialysis in Oyster Culture. Proc. Acad. Nat. Sciences, 27. I875, pp. 442-43. 
The generative organs of the oyster, Gen. Fig. 2, are massive in proportion to the size of the animal; they invest the whole of the visceral mass from a little behind the palps to the pericardial space, extending beyond it posteriorly above and below. They invest the rectum to within a short distance of the vent and the first bend of the intestine below the adductor muscle; their substance also dips down deep amongst the viscera so as to appear to cover the intestines, the pouch of the crystalline style and the liver. The sexes of the oyster are distinct, but

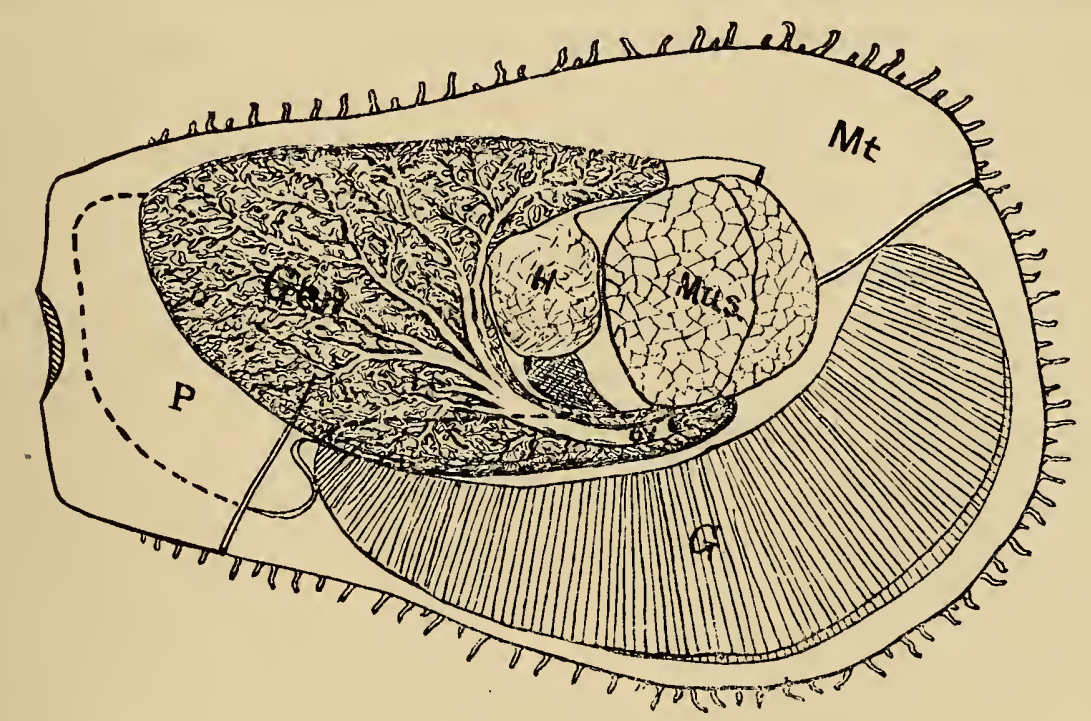

Figure 2.

there is no apparent possibility of determining the sexes from the external appearance of the generative tissues, since there seem to be no differences between what in one case are ovaries containing eggs, and in another spermaries or testes, containing the male cells or spermatozoa. Both kinds of glands are composed of a great number of tubular branches which unite into two large canals, one on each side of the body, which open into thr upper gill cavity at ov; the oviducts if the specimen be female, and vasa deferentia if the specimen be a male. The smaller branches divide and subdivide, as may be noted in Fig. 2, giving off ultimately short blind, pouchlike branches, which are the follicles of the glands or 
acini, on the inner walls of which the ova or eggs and spermatozoa are developed. The eggs in the female grow from oricells, and in the male the spermatozoa originate from cells which are known as spermogens.

In having a pair of openings, one on either side for the escape of the generative products, our oyster agrees perfectly with that of Europe, according to $\mathrm{H}$. Lacaze-Duthiers. * Davaine, $\nmid$ in his memoir, asserts both in his text and in his figures that the generative glands of the European oyster have three openings on either side, statements which are not in accord either with facts or analogy. In a paper by Sir Everard Home, which we have noticed before, he erroneously regards the suprabranchial or upper gill carity as an oviduct.

No evidence to show that our oyster is hermaphrodite was found during the entire season, nor were my searches for embryos or eggs on the mantle and in the gills any more successful than those carried on two years before by Prof. Brooks. There is no doubt whatever that the oyster of Europe nurses its young on its mantle and gills for some time, nor can we rery well question the very high authority of Möbius for saying that in most cases the sexes are separate, and that but one kind of products, riz. : either egg's or sfelmatozoa are at any one time found in the generative organs; Lacaze-Duthiers' observations seem to confirm the conclusions of Möbius.

As the eggs and spermatozoa ripen and are set set free in the little terminal sacs or acini of the generative organs, they are probably pushed or driven out of the larger canals which connect with the terminal sacs, and which join the main oriduct ov, by means of cilia which line these canals, as suggested by Lacaze-Duthiers, just as the food is carried to the mouth and the water continually forced through the gills by the waring of the innu-

\footnotetext{
* Recherches sur les Organes genitaux des Acephales Lamellibranches. Ann des Sci. Natu relles. 4 ser, zool., t. 2, pl. 8, pp. $214-228$. Paris, 1855.

† Mem. de la Soc. de Biol. IV, I8j2, pp. 297-339, pls. I-II.
} 
merable cilia which cover the latter and the palps. The oviducts open directly into the upper gill cavity, from whence the eggs or sperm which have been discharged thereinto are at once carried out into the water immediately surrounding the animal in the open sea. From the fact that the eggrs are heavier than water, although each female oyster matures many millions, it is easy to understand why it is that but comparatively few, probably only a fraction of one per centum of all that are laid, ever develope or fix themselves even under favorable circumstances, since much the largest portion of them are never impregnated, while of those which are, but few ever find positions favorable to their growth under natural conditions.

HOW AN OYSTER TAKES ON FLESH.

Amongst oystermen the business of "fattening" or feeding the oyster is one of the most important from the fact that upon the condition of the marketable product largely depends its value. Fatness in the oyster is a condition wholly different in nature from the state known under that name in stall-fed domestic animals; nor has it anything to do with the condition of the reproductive organ, as Prof. Brooks* seemis to suppose, for oysters are mainly taken from their beds at a season when that organ is in an inactive condition and appears shrunken and wasted away, as it truly is. The word "fat" as applied to indicate the condition of the oyster when in flesh, is a misnomer, since it is not fat at all which is the immediate cause of the condition of plumpness, which betokens a fitness for market, but a very extensive deposit of protoplasmic material which has been mainly laid down in the substance of the mantle. It is not denied that there are oil globules to be found in this deposit, but it is denied that the term "fat" applies as

*Development of the American Oyster, p. ro.

N. B. Mibius seems to have clearly apprehended the true nature of the so-called fattening process. 
descriptive of it. It is this relatively large amount of delicate, easily digested protoplasm of the mantle which renders the oyster so wholesome and nutritious.

The deposit of this protoplasmic material in the mantle, palps and body, stands in intimate relation to the activity of the reproductive organs. During the spawning season oysters are said to be "poor," that is, poor in condition, for at this time the mantle, especially where it lies next the body on each side, is very thin and quite transparent; the radiating muscles at the edges as well as its vessels and nerves may now be readily studied under the microscope, owing to the transparency and absence of soft granular protoplasm. If we examine at this time the reproductive organs, as a rule, we will find them greatly developed and pouring out their products through two large ducts, the combined caliber of which is not far short of that of the intestine. It will be evident to any thinking mind that if the major part of the food material elaborated by the stomach and intestine goes to the ovary or testes to be transformed into sex products, which are continually thrown off, little of such material can be stored up in the tissues of the body.This is exactly what happens. In the month of September when the oysters for the most part stop spawning, the drain of elaborated material having ceased to flow from the openings of the reproductive organs, it is diverted in another direction, but is retained in the system, and has to be deposited somewhere in the body. The most extensive deposits of this elaborated living matter occur in the mantle, body and palps, the color of which rapidly changes from the watery transparent condition prevalent during the spawning season to a creamy white. The mantle and palps now become very much thicker than before, and their substance appears to be softer, more easily lacerated, and is made up largely of a delicate granular protoplasm, which when broken up has the milky appearance of the reproductive organ 
when it is mutilated. I have known this milky appearance of the mutilated mantle of the oyster to lead persons to mistake it for the reproductive organ; a mistake easily made by the inexperienced.

The preceding account of the physiology of the socalled fattening process will serve to prove how little philosophy there is in the doctrine that oysters may be fattened by putting them for a day or two in water less salt than that from which they were first taken, in order that they may be water-swollen by the action of osmose so as to give them a plump appearance.

Upon making an examination of some oysters to-day (Dec. 6th,) to learn something in regard to the nature of the so-called fatty material contained in the thickened mantle, I find that it is made up of nucleated cells composed of a fine corpuscular material. The protoplasmic granules are so fine that they remind one, when examined under a power of 250 diameters, of the corpuscles found in milk, though they are probably quite different in nature. They manifest the dancing motion when highly magnified, which is known as pedesis or the Brownian movement, and appear to be perfectly spherical with considerable variation in size. Upon examining another specimen I found the principal ducts of the testes already defined, and upon microscopic examination an abundance of active, though not perfectly mature, spermatozoa were noticed. The spermaries in this case may no doubt be considered as a part of the fat, but the case is most interesting as showing how very early in the season the generative products commence to develop.

HOOD OF THE OYSTER.

The food of this mollusk, as is well known, consists entirely of microscopic beings and fragments of organic matter, which are carried by currents from the palps and gills, which have been already described, to the large mouth of the animal at the hinge end of the shell. The inside of the gullet and stomach, like some other parts of 
the body, are covered with cilia, so that food once fairly in the mouth will be carried by their action down to the cavity of the stomach, where it is carried into the folds and deep pouches in its walls and even into the openings of the bile ducts, to undergo digestion or solution, so as to be fitted in its passage through the intestine, to be taken into the circulation, and finally disposed of in building up the structures of the body.

Along with the food which is taken, a very large amount of undigestible dirt or inorganic matter is carried in, which in a great measure fills up the intestine together with the refuse or waste from the body. This material, when examined, reveals the fact that the oyster subsists largely on diatoms, a low type of moving plants which swim about in the water encased in minute sandstone cases or boxes of the most delicate beauty of workmanship. These, when found in the intestine, have usually had their living contents dissolved out by the action of the digestive juices of the stomach. I have found in our own species of oyster the shells of three different genera of diatoms, viz. : Campylodiscus, Coscinodiscus and Navicula. The first is a singularly bent form ; the second is discoidal, and the last boat-shaped, and all are beautifully marked. Of these three types, I saw a number of species, especially of the latter, but as I was not an authority upon the systematic history of any of them, I had to neglect the determination of the species. No doubt many more forms are taken as food by the oyster, since I saw other forms in which the living matter inside the silicious cases was brown, the same as in most of the preceding forms, which I have indicated. Some of these brown forms were so plentiful as to color a considerable surface whereon they grew, of the same tint as themselves. But in no instance have I found any indications of the animal of the oyster becoming colored by feeding on these diatoms, as it is said the European oyster does when feeding on Navicula ostrearia, which 
is green, imparting its own green color to the fluids and thus to the tissues of such oysters as may be so situated as to readily feed upon it. A recent writer* gives an account of some experiments made by M. Puysegur of Sissable in artificially producing this green color, from which I quote: "In each plate, [filled with water charged " with green diatoms, ] according to its size, we put three "to six perfectly white oysters which had never" been in " the 'clears' and the shells of which had been previously "washed and brushed clean. In similar plates like num"bers of the same oysters were laid in ordinary sea" water. Twenty-six hours after the commencement of " the experiment the oysters in the water charged with "diatoms had all acquired a marked greenish hue; the "other oysters remained unaltered. * * * * "After the oyster had turned green, it was laid in ordi" nary sea-water for a few days, when the greenness dis"appeared altogether. It reappeared when the oyster " was replaced in fresh water containing Navicula ostre"aria:" M. Decaisne, of the Jardin des Plantes, Paris, repeated the experiments with the same results.

Besides the diatoms, the spores of algae, the larvae or young of many animals, such as Sponges, Bryozoa. Hydroids, Worms, Mollusks, many of which are small enough to be taken in by the oyster, though their bodies in most cases being soft and without a skeleton, it is impossible to find any traces, either in the stomach or intestine, of their remains, to indicate that they have formed a part of the bill of fare of the animal. What, however, demonstrates that such small larval organisms do help to feed the oyster, is the fact that, at the heads of the small inlets or creeks along the Chesapeake, where the water is but little affected by the tides and is somewhat brackish and inclined to be stagnant, there always appears to be a relatively greater development of a some-

\footnotetext{
*'The green color of Oysters, H. M. C. In Nature, Vol XXII, 549-50, 1880. 'Trans.
} from the Revue Maritime et Coloniale, February, 3880. 
what characteristic surface or shallow water fauna of minute forms.

In St. Jerome's Creek the microscopic fauna of its head waters is entirely different from that of the body of the creek; two minute forms inhabit in vast numbers the former, while I sought in vain for them in the more open and changeable waters of the main body of the inlet, which are brought into active movement twice a day by the action of the tides. One of these forms an Infusorian $^{*}, 1-25$ th of an inch in length, was found covering every available surface of attachment, so that countless multitudes of the naked young would be swimming about in the water previous to building the curious spiral tubes which they inhabit; admirably fitted in this state as food for the oyster. Beside the type referred to there were a number of other Infusorians which in their socalled swarming stages of development, the young would become available as oyster food. Of such types I noticed four different species, either belonging or very nearly related to the genus Cothurnia; all of the forms built tubes for themselves. I also noticed several forms of bell-animalcules, the swarmers of which would become available as food for the oysters lying in the vicinity.

The diatoms did not seem to me to be more abundant in the head waters than in the open creek. There was one moss animal, of remarkable character, which I found in the head waters only, this creature was very abundant, and no doubt its embryos like those of the infusoria referred to, were available as food.

Of free swimming Infusorians, I noticed a number of genera; one especially attracted my attention from its snake-like appearance and singularly rapid contortions ; it had a tuft of vibrating hairs or cilia at the head end in close relation with the mouth. Another more abundant type was the curious genus Euplotes, with a thick shell enclosing the soft protoplasm of the body; the latter

*On the occurrence of Freia producla, Wright, in the Chesapeake Bay. Am. Naturalist, 1880, pp. 8:0-11. 
was of an oval form, flat beneath and rounded on the back, so that the resemblance when the large foot like cilia were in motion, carrying the animal about, was strikingly like a very minute tortoise, the resemblance being heightened when the animal was viewed from the side.

Rod-like algae, of minute size, the larvae of crustacea, especially the vast numbers of extremely small larval Copepoda must enter as a perceptible factor into the food supply of the oyster.

There is no doubt but that the comparatively quiescent condition of the head waters of these inlets and creeks, available as oyster planting grounds, are more favorable to the propagation of minute life than the open bay or creeks, where the temperature is lower and less constant. Practically, this is found to be true. For oystermen seem to be generally agreed that oysters "fatten" more rapidly, that is, feed more liberally in the head-waters, blind extremities of the creeks, than elsewhere. This notion of the oystermen is in agreement with my own observations during the past year. Oystermen also assert that oysters "fatten" more rapidly in shallow waters than in deep ones, a point upon which I made but few observations, but such as I did make tended to confirm such an opinion. In illustration I may contrast the condition of the oysters in the pond leased by the Commission at St. Jerome's and those dredged off Pt. Lookout in 20 or 30 feet of water, on the 3d day of October, 1880. 'The oysters in the pond, by the middle or end of September, were in good condition as to flesh and marketable, while those from deeper water off $\mathrm{Pt}$. Lookout and but little later in the season, were still extremely poor, thin and watery and utterly unfit for market. 'These differences in condition, it seems to me, are to be attributed in a great measure to differences of temperature and the abundance of food, but mainly to the latter. 
THE OYSTER CRAB AS YESMATE AND PURTEYOR.

It is many years since Mr. Say named the little oystercrab of our coasts Pinnotheres ostrentm, and its habits in relation to the oyster seem to have excited but little interest. especially in foreign writers. Prof. Terrill, in his report to the U. S. Fish Commission, obserres that it is the female which lives in the orster. and that the male which is smaller and quite unlike the female, is rarely, if erer seen to occur. but that it has been seen by him swimming at the surface of the water in the middle of Tineyard sound. His statement that it occurs whererer oyster's occur, I cannot agree with, since out of many hundreds of St. Jerome's oyster's which I saw opened, I nerer saw a specimen of Pinnotheres: they may occur, but rarely. This little crab has quite a number of allies which inhabit rarious living mollusks, holothurians, etc., of which admirable accounts are giren by Tan Beneden in his work on Animal Parasites and Messmates.

There can be no doubt that the oyster-crab is a true messmate. and it is highly probable that the presence of these animals in the oyster is rather to be regarded as adrantageous than otherwise. The animal lires in the gill carity of the oyster, and, as will be seen from the following observations. may be the means of indirectly supplying its host with a part of its food. During a reconnoitering trip down the Chesapeake on the racht "Lookout," in the first week of .July last. in dredging, some oysters were hanled up which contained Pinnotheres. In the case which I am abont to describe. the included crab was a female with the curiously expanded abdomen folded forwards under the thorax and partially corering a huge mass of brownish eg.g. Upon examining these egg's what was my astonishment to find that they afforded attachment to a great number of compound colonies of the singular bell animalcule. Zoöthamnium arbusculum. Upon further examination it was found that the legs and back of the animal also afforded points 
of attachment for similar colonies and that here and there where some of the individuals of a colony of Zoöthamnium had been separated from their stalks, numerous minute rod-like vibriones had affixed themselves by one end. In this way it happens that there is a quadruple commensalism established, since we have the Vibriones fixed and probably nourished from the stalks of the Zoöthamnium, while the latter is benefitted by the stream of water drawn in by the cilia of the oyster, and the last feeds itself and its protegé, the crab, from the same foodbearing current. Possibly the crab inside the shell catches and swallows food which in its entire state could not be taken by the oyster, but in any event the small crumbs which would fall from the month and claws of the crab would be carried to the mouth of the oyster, so that nothing is wasted. We must consider the crab with its forest of bell animalcules in still another light. Since the animalcules are well fed in their strange position, it is but natural to suppose that they would propagate rapidly. They multiply in two ways, viz.: by dividing both lengthwise and crosswise, one half of the product being set free, and known as swarmers. These cast off germs of the animalcule colonies are no doubt hurried along in the vortex created by the cilia of the gills and palps, carried to the month and swallowed as part of the daily allowance of the food of the oyster. We are accordingly obliged to look upon the Pinnotheres in this case as a veritable nursery, upon whose body animalcules are continually propagated and set free as part of the food supply of the oyster acting as host to the crab. I do not suppose, however, that such a condition will always be found to obtain, and it must also be remembered that myriads of Zoöthamnium colonies were dredged up on algae from the bottom in the immediate vicinity. Such an aloundance of germs in the water would favor their being readily transplanted or fixed to the body of the oyster-(ral). 
NATURAL BANKS.

During my stay at St. Jerome's creek. I examined the natural oyster banks which were readily accessible in shallow water, with gratifying results as to the habits of the animal under virtually undisturbed conditions.These banks, like those of Europe, always appear to be much longer than wide, but many of them are almost entirely exposed to the air during low tide, a rare occurrence, according to Möbius, with the banks on the Schleswig-Holstein coast of the North Sea. I learned from the owners of some of these banks that, although a considerable proportion of the oysters on them were at times frozen to death during the severe winters, that the fecundity of those which remained was'such, combined with the naturally farorable conditions found on the banks for the growth of old and young, as to restore the beds to their wonted productireness in one or two seasons. Whether this description of the fecundity of the beds found in shallow water is orerdrawn or not matters little, since there was the plainest evidence that we had here before our eyes the best natural conditions for the propagation and feeding of the individuals. These beds are, in a word. natural spat collecting grounds: places where such conditions obtain as will allow a large proportion of the swarming brood of the spawning season to affix itself securely and survive in positions where an abundance of food may be got. The tide ebbing and flowing orer the beds not only carries with it in suspension the microscopic food best adapted for the nourishment of the oysters, but also tends. owing to the peculiar arrangement of the shells on the banks, to keep the surface of the latter clean, so as to be well adapted as favorable points of attachment for the young.

The oysters assume an approximately rertical position, as shown in the cross-section Fig. 3, of a bank in St. Jerome's Creek owned by Mr. J. W. Wrightson. The assumption of this position seems perfectly natural; 


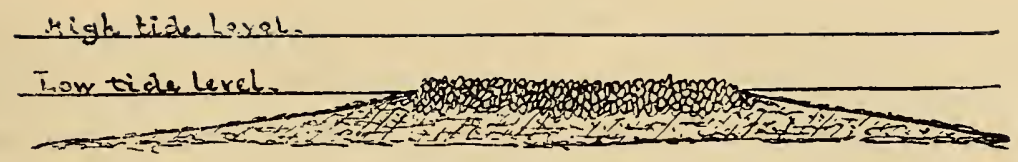

Figure 3.

with the hinge end downwards and the free edges of the valves upwards the animals are in an excellent position to feed while the outside vertical surfaces of the valves are well adapted to afford places of attachment for the "spat." The latter however seems to attach itself in the greatest abundance to the old oysters fixed at the surface of the bank. If one removes oysters from these beds they are found to adhere together in clusters as shown in Figs. 4 and 5. Carefully observing the char-

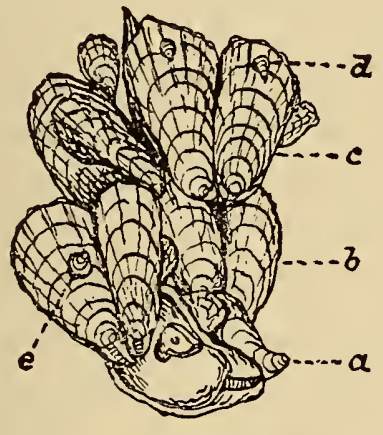

Figure 4.

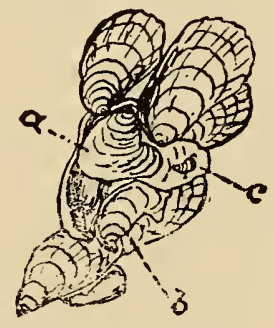

Figure 5.

acters presented by these masses, it is soon noticed that they consist of a series of generations which have grown one upon the other. In Fig. 4 four generations may easily be made out, as indicated by the letters $a, b, c, d$ : in ascending order the oldest generation $a$, is represented by dead shells, which are buried in a black, sandy material, which has acquired solidity from the large quantity of imbedded dead shells which it contains. Attached to the upper edges of the dead valves of $a$ follows generation $b$, which consists in part of living and in part of the shells of dead animals; on the preceding the living uppermost generation $c$ is fixed, which affords attachment to a generation of young $d$, though where there are open cavities the lower generations may bear 
spat as indicated at $e$. Whether it is proper to regard the superimposed series of individuals as generations may be questioned, but as no more expressive word occurs to me, I wish to be understood as using it here with qualifications.

The "spat," upon careful examination of these beds, we learn does not fix itself in any constant position; in some cases the young may have the hinge of the shell directed downwards, upwards, or to the right or left hand. Curiously enough the shells do not grow in the directions in which the free edges of the valves are made to assume in the young. Should the young happen to be fixed hinge downwards the free edges of the valves grow directly upwards; in case the hinge is directed either to the right or to the left the layers of lime will be deposited in such a way upon one side as to cause the free edges of the valves to be eventually directed upwards, causing the umbonal portion of the valves to describe an arc of $90^{\circ}$. In case the hinge is at first directed upwards the layers of carbonate of lime will be deposited in such a way by the mantle as to bring the mouth of the shell upwards as shown in the individual $a$ Fig. 5. The attempt to get into a vertical position has only been partially successful however, in this last case, since the arc of $180^{\circ}$ seems a little too much to be traversed in this way, even by the wonderful persistence of effort of the inhabitant. This struggle to assume the upright position is shown by the curved umbos and lines of growth in other individuals, both old and young, as indicated in the cases of $b c$, Fig 5 . The habit of growing in the erect position, where the banks are prolific and undisturbed causes the individuals to be very much crowded together, so that they do not have a chance to expand laterally. From this cause the individual oysters become very narrow and greatly elongated; the peculiar forms which result are known as "cat'stongues" amongst oystermen, probably from a sugges- 
tive resemblance in shape to the tongue of a cat. ${ }^{*}$ Dr. C. A. White informs me that he has noticed oysters in the fossil state, which occupied a vertical position in a sandy matrix, a fact which. shows that the habit so strongly marked in modern banks must be a very ancient one.

All the observant writers upon the oyster agree that it is essential that the bottom upon which oyster banks are to be permanent should not be liable to shift or be covered by mud or sediment carried to the beds by the tide waters. The comparatively meagre experience which the writer has had has strongly enforced such a conclusion. The permanent banks, owing to the great number of dead shells scattered through the bottom soil upon which they have been established, acquire a peculiar solidity or fixedness which the currents of tide water cannot sensibly affect. When once these banks are covered by the clusters of oysters more or less, securely held together by the lower portions being imbedded in the soil below, and mutually wedged together by the many surfaces of contiguous clusters becoming neatly adapted to each other by pressure, it is a very hard matter for the tides to smother the bank unless sufficient soil in suspension is carried by the waters to completely cover the animals. The inferences to be drawn from the foregoing studies are very important. They lead naturally to the inquiry whether artificial oyster beds cannot at least be established in shallow water, where the difficulties in altering the character of the bottom so as to adapt it to the wants of the oyster, are not practically insurmountable. I believe that the establishment of artificial beds in a moderately rapid tide way. is possible. The localities, I apprehend, are abundant along both the eastern and western shores of the Chesapeake, and I

\footnotetext{
*The crowded condition of the banks may be inferred from the fact that as many as 40 oysters were counted by me in an area included in a quadrangle of wire including exactly one square foot : 30 individuals to the square foot was a fair average on the bank examined. Where the "cat's-tungues" are developed, a much more crowded condition probably prevails.
} 
certainly know of no place where the natural conditions offered are any better for such a project than those of St, Jerome's Creek. The bottom would of course have to undergo such preparation as would insure to it solidity, and it might be well to imitate the flat ridge-like character of the bank as shown in Fig. 3. The long axis of the beds should probably lie transversely to the direction in which the tide ebbs and flows in and out of the creeks, as appears to be the case in all the banks examined. The next thing to do would be to colonize these banks with oysters stuck thickly into the bottom, hinge downwards, imitating the position of the animals in the natural banks. The cost of an experimental bank established as I have suggested, need not be much, as the experiment could be tried as successfully on a limited scale as upon a more extensive one.

WHY DREDGING INJURES THE BEDS.

Dredging, inasmuch as it destroys the arrangement of the oysters of the banks, tends to interfere with the fecundity of the latter. Carry on dredging operations on any given bank long enough to rob it both of its natural growth of adult oysters and in part of its natural growth of spat, it would be strange indeed if it did not cease to be productive. As we had occasion to remark above, that the uppermost tier or last generation of oysters was the one which afforded for the most part the points of attachment for the young fry, it is clear that the banks are annually robbed of vast numbers of possible oysters. True, the dead shells which are or ought to be allowed to remain on the beds, lying about amongst the living individuals also afford attachment for the young, but perhaps not more liberally than the living shells.

Another reason why dredging, especially when carried to excess, tends to destroy the banks, as insisted upon by Mobius and others, is the removal by that means of too large a proportion of germ-producing adults. It is in this way that the power of the beds to regain their 
productiveness is enfeebled or destroyed. Amongst the oystermen there seems to be a widespread indifference in regard to this matter, but it is to be hoped that these persons, who, more than any other class, are directly interested in the maintenance of the productiveness of the beds, will see the evils of excessive or indiscriminate dredging before it is too late to repair the damage done thereby.

The following propositions which have been laid down by Prof. Möbius, are as applicable to the conservation of our own species as to that of Europe :-

"An oyster bank will yield permanently the greatest profit if it possesses such a stock of full grown oysters as will be sufficient to maintain the fecundity of the bank in accordance with its bioconotic conditions.

"When the natural conditions will admit of it, the yielding capacity of an oyster bed may be increased by improving and enlarging the ground for the reception of the young brood.

"The natural banks should be improved by removing the weeds and plants with dredges and properly constructed harrows, and by scattering the shells of oysters and other mollusks over the bottom.

"When circumstances will permit, all the animals which are taken in the dredge, and which kill the oysters or use up their food, should be destroyed.

"It would be much more judicious and much better for consumers, if the 'close time' could be extended until the 15th of September or the 1st of October, so as to allow the oysters some time after the expulsion of the contents of the generative organs to become fat before being brought to the table.

"If it is desired that the oyster banks should remain of general advantage to the public and a permanent source of profit to the inhabitants of the coast, the number of oysters taken from the beds yearly must not depend upon the demands of the consumer or be governed by high 
prices, but should be solely regulated by the amount of increase upon the beds.

"The preservation of the oyster beds is as much a question of statesmanship as the preservation of forests."

The foregoing suggestions, emanating from such high authority, serve to enforce what has been said in relation to dredging and the constitution of the banks and their extension. The possibilities which seem to await development along the shores of Virginia and Maryland at the hands of enterprising oyster-culturists are almost limitless, unless, as may be the case, given areas of waters adapted to their culture, will afford food for only a given number of oysters.

\section{FAUNA OF THE OYSTER BEDS.}

The animal forms which are encountered on the oyster beds and in the surrounding waters are exceedingly numerous, and range in size from the most minute monads, Vibriones and Bacteria up to fishes and other types of considerable size. Whether the Sheep's-head Archosargus probatocephalus, frequents the oyster beds or not I do not positively know, but I strongly suspect that it does. My reason for this belief is that I find the half digested remains of the common branching. crimson-rolored sponge Microciona protiferum in their stomachs, together with the crushed shells of mussels (Modiolaria and Mytilus.) These last can be best obtained by the fish from submerged rocks to which they are attached, but the sponge which grows in considerable abundance on the oyster beds would attract these animals, where they might do some damage to young oysters with their powerful cutting and grinding teeth. Other fishes are found on the banks such as the sole, Achirus lineatus, the true toad fish Batrachus tau; the outer gill openings of the latter were usually surronnded by a phalanx of parasitic crustaceans nearly allied to the genus Caligus, provided with a pair of discoidal suckers on the forepart of the under side of the body. Puffers (called "toads" 
on the Chesapeake,) were also noticed, of two species, belonging to the genera Chilomycterus and Chilichthys. Though the Batrachus is also called the oyster-fish, but in opening a number to examine the contents of their stomachs I found no evidence of the remains of oysters, nor does the conformation of the mouth indicate that the fish is in the habit of destroying oysters for food. The teeth of the puffers look as if they might be much better adapted to crush the shells of live oysters, especially those not over a year old. In the Museum of the Academy of Natural Sciences of Philadelphia there is a specimen of a blenny $3 \frac{1}{4}$ inches in length, which was taken from an oyster $4 \frac{1}{2}$ inches long by Mr. C. W. Hyatt. On the inner face of both valves the fish, which is apparently a female, has laid its eggs, which are adherent, and cover nearly half the inside of both valves. Although this specimen is interesting and somewhat puzzing, I do not think that the little fish can be accused of destroying the oyster in order to make a comfortable spawning nest for itself. It seems very likely that the animal of the oyster was destroyed in some other way, and that the blenny finding the shell abandoned made it the repository for its eggs, which seem to be partially embedded in a layer of some whitish secretion.

Prof. Möbius alludes to the observation of Captain Johnston, who says, in the Report on the Oyster Fisheries, made to the House of Commons, $18 \% 6$, that he saw small fishes of the genera Gobius and Mullus swallow the brood of the oyster as the latter discharged it from its parted valves, and that he afterwards canght and opened the stomachs of the fishes and found the fry in them. Since our oyster discharges its eggs directly into the water before development, when they measure only me five hundredth of an inch in diameter, I think we will not need to be alarmed about the destruction of embryos by small fishes, since $\mathrm{I}$ know of no species which fiequents the oyster beds whose gill-raker's are close enough 
together to catch and hold an object as small as this.

Ascidians or tunicates were quite comnon and they appearea to be of but one species; one of the smooth forms of Bolgrila.

A single specinem of a small star-fish was met with. Some Pycnogonids and marine mites were noticed but not identified. Crustacea were present in great abundance. the large edible crab callinectes hastatus was abundant and a few indiriduals were seen which were in the megalops stage of growth. Species of the genera Sessarma and Gelasimus were abundant amongst the grass along the shores of the creeks and inlets. Amphipols or sand hoppers were abundant and a number of other smaller forms were occasionally picked up while using a fine net, as well as the larvae of fish-lice (Cymothoids, wimming about actively in the water. The Copepoda were very numerous and appeared to be the principal cause of the luminosity of the water when the net or a stick was made to more through it quickly. It was these, possibly. that the Menhaden was straining ont of the water as food. by means of its seive-like gill-rakers, for I always saw these fishes swimming along with their mouths held constantly open.

The entoproctous breozoan Pedicellina americana Leidy. was rely abundant in the pond leased by the Commissioners for the work of artificial orster culture. Prof. Leidr, howerer, has either described another species than this one noticed by me, or else he has placed the stomach in a position the reverse of what it occupies in nature. The various species of ectoproctous forms I did not have the means at hand to identify: some of the creeping branched forms were common as well as a number of encrusting species.

Annelids allied to the genus Meckelia were found in abundance. creeping around inside of the large tubular efferent openings of a pale yellow incrusting and also massive siliceous sponge, the spicules of which were 
knobbed at each end. Nereids were common, of moderate size, and an exceedingly slender Oligochaetous worm, bright red in color, was dug up out of the sand, sereral inches below the surface. Planarians were quite frequently noticed creeping orer the surfaces of the slate collectors.

Amongst the lamellibranchiates noticed as inhabiting St. Jerome's creek, besides the oyster, was a very destructive boring mollusk related to the true ship-worm, but generally considered to represent another genus, $X$ ylotrya fimbriata. So rapidly does this creature bore into wood immersed in the sea that a small pine hatching-box which I had placed in the tide-way to retain impregnated oyster-eggs, was almost destroyed in the short space of 51 days. This mollusk is found at work at the heads of the creeks, where the water is sometimes slightly brackish, just as industrionsly as elsewhere. The ova, which, according to my observations, are almost identically of the same appearance and size as those of the oyster and soft-shelled clam, are produced by the animals in vast numbers and set free into the surrounding water, where they are apparently fertilized by contact with the male cells set free by the males. The embryos develop rapidly, swim about and soon find a place to fix themselves on some piece of wood in great numbers, when the work of destruction begins. 'These animals, in the creeks and inlets of the Chesapeake, will no doubt canse considerable trouble to oyster-culturists in destroying the lumber used in making the collectors, nurseries and other apparatus used in conducting such work.

Solecurtus gibbus is found in the sandy flats along with a species of the Tellinidae, where the Mya arenaria also abounds, which is used extensively as bait for taking the sheep's-head. The spawning season of the $M y / d$ is short. and begins in the early part of September and lasts until the first or second week of October. During september the large visceral mass in the middle of the shell carity 
greatly and rapidly enlarges, and at this time is considered to he in good condition, or "fat." as the fishermen say. This increase in the size of the body or visceral mass is entirely due to the rapid growth of the generative organs and the ripening of the products in them. The process of coming into condition is, then, just the reverse of what occurs in the orster. The sexes are distinct, since Inever found anything except ora in the females, or spermatozoa in the males. The head of the spermatozoan differs from that of the oyster in being elongated. The number of ora set free by an adult female, judging from the relatively enormous bulk of the oraries, must be very great, and since the eggs are of exactly the same size as those of the orster. 1-500th inch, it is not at all improbable that there may be as many as $100.000,000$ matured. I succeeded in impregnating the eggs artificially on the 13th of September last. and watched their development until the gastrula stage hak been reached. when my observations came abruptle to an end.

The importance and ralue of this delicions mollusk is hardly appreciated on the Southern coast as it should be. and it appears to me that the artificial culture of it should be almost as much of an object as that of the oyster, with which it will compare very farorably when properly serred at table.

The nussels inhabiting St. Jerome's Creek appeared to belong to the genus Mortiolaria: no true IVytitus being noticed.

A few Gasteropods were noticed, consisting of three species of nudibranchiates-(without shells, and a few very small univalves, the only larger uniralre was Littorina irrorata. which was rerr common. sticking by means of the foot to the stems of the tall grass fringing the shores of the creeks. No species of boring mollusk was noticed in the waters of St. Jerome's. so that orsterculture may probably be mondurted there without harm from the Urosalpinix, or " Nrill" as it is called. There 
is no doubt however about their existence in some other parts of the bay. Slipper limpets were frequently observed adherent to the ontside of oyster shells, the only species though, which I observed, was the one called Crepidula glauca. The unripe eggs of this animal have a very remarkable structure, the nucleus containing a large and very refringent nucleolus which looks like two spheres partially fused together, from this body to the walls of the nucleus granular protoplasmic lines extend in a very irregular radiating manner. These granular lines sway and twist about while the fresh egg is viewed under the microscope, like a spider's web, which may be supposed to have been endowed with life and the power of moving any part of itself. E. Van Beneden and $\mathrm{O}$. Hertwig figure very similar immature ova occurring in other animals.

A number of sponges were observed; all of them siliceous; some of them incrusting stones and oyster shells, others were branching or massive and usually of a yellow, yellowish or dirty white color, except some leather sponges (Geodia?) which were purplish and anchored in a most remarkable manner to the bottom. The redsponge, Microciona proliferum is very common, but the species which most concerns the oyster culturist is the boring sponge, the substance of which is deep orange in color. The boring sponges, Clion but whether they really destroy many living oysters in this country is probably not ascertained. That they can effect the destruction of the oyster there can be no doubt from the following which I published over a year and a half ago elsewhere." "In a specimen of the common "Ostrea virginiana, recently handed me for examina"tion by my friend Mr. John Ford, the substance of the "shell was thoroughly cavernated so as to render it ex"tremely brittle and readily crushed; in fact the imner "takle of the shell left standing showed a great number"

*On the Destructive Nature of the Boring Sponge, etc. Am. Naturalist, X111, x879, p. 28r. 
"of elevations within. which indirated points where the "intruding parasite had been kept out hy the orster "which had deposited new layers of calcareums matter" "at these places so as to gire rise to the elerations spoken " of. Besides this, the inner table had become so weak" ened at the insertion of the adductor moscles that the "aninial in closing had liroken a jart of it loose. the "break having been repaired by the deposition of a "brown horny substance." In such cases. as I have just described, it is clear that serions damage nay be done to the insertion of the adductor muscle. the perfect integrity of which and power to close the ralres must be maintained, or there is a possibility that the orster may be invaded by some hungre carnirorous neighbor and have its ritals eaten awa without being able to shut out the intruder. In buying "plants" it would probahly be best to select only such cargoes of oysters as appear to hare clean unbored shells. or such as are not " wormeaten." since I am told by a practical orsterman. Mr. J. W. Wrightson. that a bed once planted with orsters which are badly infested with cliona or the boring sponge. are apt to remain so for some time and that the beds adjoining became infested for the reason that the embryo sponges which are thrown off in large numbers from the infested "plants." swim about in the water, attach themselres to other orsters commence to grow and to bore.

The protozoan famna of St. Jerome's Creek presents considerable rariets: three species of test-building $\mathrm{Co}$ thurnia were noticed, one Taginicola. three species of Torticella or bell-animalcules. free swimming Euplotes, Nassulas: of the latter type an exceedingly elongate form was noticed. with a bodr almost as slender as a thread-worm. Monads were sometimes noted in profusion. though some of these may have been the spores of algale. Amoeboid forms were rerr few. and the only one which was frequently noticed was a form so nearly 
like Actinophrys sol that I would pronounce it the same.

The Freia producta Wright, was most common; this creature is related to the fresh-water trumpet animalcules, and is one of the most beautiful protozoans I have ever seen. I reproduce here, with some changes, my description of the Chesapeake form from the American Naturalist for November, 1880. "The tubes in which "the animalcules reside are formed of a narrow trans"parent ribbon of horny consistency, wound into a spir"al and terminating in a trumpet-shaped extremity from "which the odd peristome of the inhabitant protrudes. "The basal or attached end is usually bent at an angle "to the tube and bears a striking resemblance to the "foot end of a stocking resting upon the sole. This por"tion is not composed, like the tube, of a spiral ribbon, "but is simply a thin-walled sac, from the open-end of "which the ribbon takes its rise, but it is composed of "the same kind of material. Many of the tubes show a "trumpet-like rim projecting from the sides of the form"er, a little above the middle, and of the same form as "the terminal rim, showing that this, like the form de"scribed by Mr. Wright from British waters, may stop "building its tube for a time and then recommence.

"The adnlt animal tube and all, when fully extended "will measure 1-25 of an inch in length. It is of the "same color as Stentor cceruleus, or bottle green, but has "the power of elongating and twisting itself as greatly as "S. roeseli. The peristome is quite unlike that of Freia "ampull $\alpha$, and bears a strong likeness to the blades of a "pair of obstetrical forceps. The blades are deeply "grooved, forming a deep ciliated demi-canal with paral"lel saides, and at the junction of their bases lies the "spacious, twisted and spirally ciliated pharynx, which "is bounded dorsally and ventrally by the prominent "folds which unite on either side with the long, curved "]obes of the peristome. There is a small basal disc "as in Slentor, and the ectosarc is traversed as in that 
"genus by parailel granular bands. regarded as muscu"lar fibers by some writers. The usual food-balls and "vacuoles are present. and I was enabled to define "sharply the endosarc from the ectosarc, and clearly "see the long, beaded nucleus. The tube or ribbon"secreting" organ described by Wright I was mahle to - discorer.

- When fully extended the basal portion of the animal - becones attenuated to a thin binish filament, which "widens twrards the peristome, where the body is orer "half as thick as the insicie diameter of the tube. Then "fully retracted and resting, the animal resembles in its "oblong shape a retracted and resting stentor, and meas" mes about 1-10 as long as when fully extended. The "ribbon which forms the tube makes from fomr to twenty"four turns in specimens of different ages."

THE FATNE OF OYATER BEDS AS INTERDEPEXDENT COMULNITIES.

Möbius calls an oyster bank a Biocoenosis or interdependent community of life. The many species of animals found on the banks and beds are no doubt more or less mutually dependent upon each other for subsistence, but this is perhaps not any more true of oyster banks than it is of terrestrial faunce. There are no doubt rast numbers of Hoating embryos of oysters eaten by other animals growing on the beds which bring their food supply to themselres by means of currents produced by ciliary motion. On the other hand there are no doubt vast numbers of the minute swimming embryos of these. drawn in and swallowed by the oyster. which nay indeed, for aught we know, in this way swallow many of its own young, for the current produced by the oyster hy means of the cilia clothing its gills is by no means a feeble one. though it is exceeded in power by the current flowing into and out of the siphons of Iya. In the latter I have frequently, upon opening the animal, found several Copeperta plainly risible to the naked eye swimming about in the water in the 
inferior mantle cavity, which had evidently been drawn in by the inward current. It is plain in this case that very mild means may become effective as prehensile and destructire agents, so as to bring remotely related types into intimate vital relation. Thongh an animal may be apparently invulnerable on account of the effectiveness of its covering, it cannot emancipate itself from the abiding strnggle it has to make to obtain food, no matter how passively it may apyear to conduct itself. The oyster has such a character, yet it has been apparent from what has been obserred before, that it is entirely dependent for a vigorous existence upon the favorableness of surrounding conditions. The beds and banks in a true sense are interdependent communities, whose vigor may no doubt be impaired by the removal of a single one of its members. Suppose we should take away the algae, diatoms, oyster crabs, vibriones, bacteria, infusoria, in fact all the minute life, we should greatly impair if not destroy the vitality of the beds. While it is true that many of eren the smallest forms may destroy food which should jroperly be consumed by the oyster, that were it ur tor the presence of these same small forms some destructive element might attain such a development as to be more injurious still. There is therefore no doubt but that a delicate balance of power is maintained by these rivals which is best for the health of the commnnity. The stability of permanent oyster beds, it mast be remembered, furnishes the right conditions for the survival of many types. It is a place where they find both a home and plenty of food. It is the very farorableness offered by these places which tends to indure them to congupgate and multiply, and it becomes a serions question whether the artificial establishment of hanks will not in time cause the proper types to congregate and multiply so as to afford the needed food supply for the oyster's. That dentructive members of the community may also be attracted is admitted, but if the beds are established in shailow waters, as I have 
previously suggested, the destruction of such unwelcome intruder's may be very readily effected. "Drills" and boring sponges are naturally to be thought of as types which should be destroyed, while diatoms, infusoria, small polyps, biyozoa, minute algae, etc., are to be farored in every way. Those forms again, which the orster-culturist knows are there only for the purpose of getting a good living with little trouble to themselves, ought to be destroyed.

It night be an advantage to introduce certain desirable forms onto a bank, which might be supposed to be useful as a food supply. Infusoria and diatoms not previously existing might be introduced in this way : this, I think, would be especially easy in the case of the former where the type was one which is fixed during its adult life.

METHODS OF COLIECTING AND COLLECTING APPARATIS.

Not haring reached the field until the 19th of July, I did not succeed in testing the various collectors, which were for the most part modelled after those in use in France, as thoroughly as I desired. Roofing slates. tiles, shingles. oyster shells and pine cones were used to afford attachment to the young fry of the oyster: in all cases the apparatus was of course submerged, but was not allowed to sink low enough so as to be in contact with or partially buried in the mud. The most successful apparatus used was the various modifications of the slate collector, and which in practice will probably be found the most satisfactory in the long run. We first coated the slates with a mixture of lime and sand, mixed in sea-water, thick enough to corer the surfaces when dipped into the mixture with a pretty thick layer: an eighth of an inch is not too much, so that when the young fry has attained a considerable size it may be remored without injury along with the coating of mortar, a method first introduced in Europe by Dr. Kemmerer. though he used 
another composition. The coating should be made of a good strong mortar, about one part of lime to two of sand, and after it is applied it should be allowed to set for several days under cover before the prepared slates are made up into series in frames of various sizes and put into the water. Cement alone does not answer the purpose, as it becomes so extremely hard in the course of time that it cannot be readily removed from the surfaces to which it has been applied, which of course renders it practically useless. The slates after they are prepared were fastened into frames about two feet high, the ends being let into notches about an inch or so apart. In this way a dozen could be made up into one frame, which held them horizontally at a good distance from the bottom and far enough opart to allow the water to pass readily though between the slates, giving the floating embryos a good chance to fix themselves to the mortared surfaces. Other frames were made of an oblong shape, one foot wide and six or eight feet long, the edges of the long side pieces were deeply notched with the saw every three or four inches apart to reveive the one edge of a slate, which was held in a vertica] position when the frame was laid down horizontally. Some of these frames would hold twelve or fourteen slates in position at once. In other cases the slates were simply coated with mortar and laid in rows horizontally upon parallel poles supported above the bottom a few inches. In other cases again the slates were suspended upon galvanized wire by the four corners, in a tier of 4 or 5 , about an inch apart. I also suspended them singly by means of galvanized wire. I did not however obtain the same results from all of the apparatus. The conditions were such however in most cases as to make it extremely difficult to make a fair comparison. Where the slates were in a horizontal position more mud seemed to be deposited on the rpper side which interfered with the attachment of the spat on that side, while the comparative shade kelow 
and freedom from mud seemed to faror the fixation of the fry. The slates which occupied a reltical position did not as a whole yield results as satisfactory as those which were placed flatwise.

The tiles were not received in time to make a thorough trial, but they seem to be well adapted to retain their conting of mortar. so far as I have been able to judge from a dozen put into the water in the early part of October.

Shingles will not be adapted to the work. unless they can be protected in some way from the rarages of the ship-worm. as they will not last more than one season at the ntmost. eren thrngh they were coated with mortar. The difficuity in fastening the shingles together is much greater than in arranging the slates. which also have the merit of being indestructihle if proper ly cared for.

Chaplets of orster shells were also tried: the shells were taken, a hole punched thromgh the centre and strung mpon galranized wire. This and nimst he supported upon a framework or suspenich to stakes, as the strings of shelis are heary and rery quickly sink to the bottom. They have the merit of being cheaply made since the only thing it is necessary to bur is the wire, which costs but a tritte. I am told by haj. Ferguson that this trpe of collector is very effective as used in practice by the French. Other shells will answer the same rurose. such as those of the white clam, etc.Another form which was siggested by my assistant. Mr. WT. P. Sanerhoff, has the adrantage of being bourant. This trpe was made of pine cones. of which we could obtain an abundance near the pond. They were strung on wire in the form of chaplets, six or eight of which were fastened at one end to a stake and weighted down at the other. and arranged so as to radiate like the spokes of a wheel from the stake. The cones howerer tend to accummlate mud which lodges between the scales: their effectiveness was not determined, since they were 
unintentionally placed in a rather unfavorable position.

Brush or fagots have not given the best results, as collecting apparatus they are apparently ineffectual where there is much sediment in the water, and appear to be more effective in places were the water is in rather active motion. I have been informed however, by an old oysterman, that pine bushes stuck securely into the bottom in dense lines have been found very effectual, so much so that an oyster planter following this plan had the satisfaction of seeing the bushes loaded with "spat," much of which afterwards grew to marketable size. Thick palisades might be constructed of brush stuck into the bottom near permanent oyster-banks, with good results; indeed, I do not doubt but that banks might in some cases be established by this method, if, in addition, oyster shells or stones were strewn on the bottom along either side of the brush palisade, in order to afford a foundation for the fixation of the first generations of oysters.

FLOATINA COLLECTORS.

Although I have not tried any form of floating collector with much show of success, for theoretical reasons it is a form which should not be left ont of consideration. After my experiments with impregnated eggs in floating: boxes, some of the latter were abandoned, and upon these and the bottoms of our flat boats young oysters fixed themselves, though not more numerously than upon the slate collectors. Probably the clean black surface of the bottoms of the boats was a favorable place for "spat" to attach itself.

A form which suggests itself to me could be very simply and cheaply made. I would use common plastering laths, which should be nailed together in a simple way, say in frames two or three feet square, with the laths an inch and a thalf apart. Then these frames should be dipped into a mortar the same as the slates and coated with a pretty thick layer from which the attached "spat" 
wonld be readily freed. 'These frames I would then have arranged in lines or series with wooden floats, moored close to an oyster bank, in order that the floating embryos from these banks night the more readily find places on the surfaces of the frames to fix themselves.

Floating shingles thinly coated with cement as a protection against the ship-worm, fastened together with wire so as to form large squares, might also be used in the same situations with good results. The ship-worm might be allowed to destroy the shingles as they would still answer the purpose long enough to allow the "spat" to acquire a considerahle size, and afterwards be easily broken up when it became desirable to use the "spat" in the "nurseries" or as "plants." But such a practice if long continued might prove disadrantageous, inasmuch as the cultivation of the ship-worm would also be effected. a business not at all protitable where other submerged wooden structures were in use which it was desirable to protect from this destructive creature.

The only adrantages to be secured by the use of floating collectors would be in proriding a means for floating embresos to fix themselves. Whather the free swimming embryo oysters will really affix themselves nore freely to a floating apparatis can of course only be determined by experiment. At times it seemed to me that the collectors which had heen placed nearest the surface had canght the most fry, in other cases this seemed not to be the case. There remains enough evidence however to make it desirable that this plan should be thoronghly tested.

THE BOX-COLLECTOR.

The box-collector in use in France is a rough box three seet wide, six long and two and a half deep: it is provided inside with a tier of three trays at each end nearly three feet square; upon these trays are placed dead oyster shells and a few live, spawning oysters. This was essentially the form used hy me in my experi- 
ments in St. Jerome's Creek. Unfortunately, howerei, my experience was very adverse with this apparatus, for the reason that the sediment in the water, being carried through the openings in the sides of the box, was deposited on the shells and trays, milil, in a few weeks, it had attained a depth in some places of two or three inches. Upon making an examination of the box to see if any "spat" had attached itself to the old oysters, the dead shells or the boards, I found the search nseless. The mud seemed to have completely corered all the places which should have afforded points of attachment for young oysters. The live adult oysters however were found to be in mannificent condition in the latter part of September, for every available square inch of vertical board surface, or of such shells as remained clean, was covered with a forest of minute organismis, such as bryozoa, infusoria and diatoms, so that the canse of the good condition of the adults was very aplorent. The probability is though, that had the pond been prorided with a gate to stop the ebl and flow of the tide, that the sediment would have subsided to the bottom, and not have accumulated in the box and over its contents. "Tnder better conditions the performance of this apparatus would no doubt have been admirable.

The use of straw-mat collectors in the same place was attended with the same difficulties as in using the box. The mats, which were made of small bunches of straw held together with a warp of galranized wire placed every six inches apart, were so loaded with deposits of mud as to entirely prevent young oysters from attaching themselves.

MUD.

The origin of the black ooze at the bottom of our experimental pond can be traced directiy to the sediment held in suspension in the water which slowly eblos and Hows in and out of the enclosure, carying with it in its going and coming a great deal of light organic and inor- 
ganic déloris, the former part of which is mainly derived from the comminuted fragments of plants growing in the creek. This seemed to be the true history indicated by what was noticed in studying the box-collector. The same opinion is held as to the origin of this mud by both Coste and Fraiche in their works on oyster-culture.

There is probably no worse enemy of the oyster-culturist than this very mud or sediment. It accummlates on the bottom of the oyster grounds, where in course of time it may become deep enough to cause serious tronble. Especially is this true of ponds from which the sea ebbs anct to which it flows through a narrow channel. The falling leaves from neighboring trees in antumn also contribute to this pollution as well as heary rains which wash deleterious materials into it.

Adult oysters which are immersed in part in this mud struggle hard to shut it out from their shells. If one will notice the inside of the shells of oysters which have grown in a muddy bottom, it will often le seen that there are blister-like carities around the edges of the ralres filled with nud, or a black material of a similar character. There is not the slightest donht in my mind that in these cases the animal in order to keep out the intruding mud has had recourse to the only arailable means at its command. A great many of the oyster's in the pond are affected in this manner, but it is extremely unconmon to find shells of this kind in opening oyster's coming from a hard bottom: It is easy to understand that such efforts at keeping ont the mud from the shell will not only waste the life forces of the animal but also tend to greatly interfere with its growth. The importance, therefore, of artificial preparation is apparent. Where it is desirable to establish ponds for the successful culture of this mollusk.

Only in one case have I ohserved that the mud tencled to inpair the flarol and color of the oyster. In this instance the animal was thoroughly saturated with the 
black ooze, the very tissues seeming to be impregnated with the color, the stomach and intestine loaded to engorgement with the mud, the animal manifesting every sign of being in a decidedly sickened condition. The cause of this was probably that the shell with its tenant had sunken too deeply into the mud when the ingestion of the black ooze commenced, giving rise to the remarkable changes which I have recorded. No doubt had this condition of things persisted for long the animal would have been smothered by the mud.

MUD AND THE YOUNG FRY.

The accumulation of the slightest quantity of sediment around a young oyster would tend to impede its respiration and in that way destroy it, yet, in the natural beds there are so few naturally clean places which remain so, that it is really surprising that so many young oysters pass safely through the critical periods of their lives without succumbing to the smothering effects of mud and sediment. When it is borne in mind that at the time the infant oyster settles down and fixes itself once and for all tinie to one place from which it has no power to more itself, it measures at the ntmost one-eightieth (1-80) of an inch, it will not be hard to understand how easily the little creature can be smothered eren by a rery small pinch of dirt. The animal, small as it is, must already hegin to breath just th the same way as its parents did before it. Like them its gills soon grow as little filaments corered with cilia which cause a tiny current of water to pass in and out of the shell. Thle rearler's imagination may be here allowed to estimate the feeble strength of that little current which is of such vital inportance to the tiny oyster, and the ease with which it may be stopped by a very slight aremulation of dirt.Möbius estimates that each oyster which is horn has $\frac{1}{1,145,060}$ of a chance to survive and reach adult age, su numerous and effective are the adrerse conditions which 
surround the millions of eggs matured hy a sing]e female. that only the most trifling fraction ever develop as illustrated by the ahore calculation. The egg of the orster being exceedingly sma!l and hearier than water, immediately falls to the bottom upon being set free by the parent. Should the botton be ooz or composed of sediment its chances of derelopment are meagre indeed. Irrecorerabry buried. the egrs do not in all probability have the chance to begin to develop at all. The chances of impregnation are also reduced. because the male and female orsters empty their generative products directly into the surrounding water. whereby the likelihood of the eggs meeting with the male cells becomes diminished. What with falling into the mud and what with a lessened chance of becoming impregnated, it is not unlikely that Möbins estimate is rery. nearly correct. but the American orster whose rield of eggs is much greater, not only on account of its larger size. but also because the egg's are smaller than those of the European. has probably still fewer chances of surviral." The vigorous growth of small organisms on surfaces fitted for the attachment of young orsters also tends to cause sediment to gather in such places in the interstices of the little organic forest where the ego's of the oyster no doubt often become entombed or smothered by the crowded growth surrounding them.

\section{INTERFERENCE OF OTHER AXIMAL LIFE.}

We have called attention abore to the probable interference of small organic growths to the fixation of the young fry ; in practice it is found that the larger organic growths which establish themselvos on the collectors, also become injurious. The two most conspicuous types are the sessile Ascidians or tunicates and the barnacles. I have frequently found fully one-half of the surface of a

\footnotetext{
* According ro estimates which I have made based on the i"gures of the eggs of Ostrea edulis. given by MI. Davaine, they are $t-\mathrm{r}_{3} \mathrm{O}$ of an inch in diameter. Estimates based on the figures of Lacaze. Duthiers give $1-270$ of an inch. While II bius estimates the size of the yourg firy at I-I 56 of an incit.
} 
slate covered with a dense colony of ascidians; in this condition a great percentage of available surface is lost which ought to serve for the attachment of spat. The surfaces so occupied would also be comparatively clean were it not for these organisms which actually become a serions annoyance. They, like the oyster, affix themselves to the slates while still in the free swimmlng larval stage, since the surfaces designed for the oyster are equally well adapted to them. The barnacles which also affix themselves in great numbers become a nuisance for the same reason. The larval barnacle is an extremely active little creature and dashes about in the water with great rapidity. As soon as it has completed this stage of its growth, it betakes itself to some object to the surtace of which it attaches itself by the head end, when a singular change takes place, at the end of which it is tound that it has begnn the construction of the curious conical shell which it inhabits. They grow very rapidly, so that in a couple of months the shell will already measure over half an inch in diameter. In this way farther inroads are made upon the room which should be taken up by oysters.

Of course, the larger types are not alone in taking mp space, since infusorious, bryoza, polyps, etc., are also culpable, as well as algae, such as diatoms and the higher forms. The only remedy for this accunulation of animal growths on the surfaces of the slates and other collecting apparatus, will be to have the frames which hold the slate in position so arranger that each tile, shingle or slate can be removed, in order that it may be readily overhauled and these organisms remored from the surfaces which it is desired shall remain clean. This work would have to be done at intervals of erery two or three weeks, and shomld be conducted with great care so as not to remove the oysters which have affixed themselves along with the other things which it is the intention to destroy. whe renoval of the smaller forms from the surfares of 
the slate would be more difficult and attended with danger to the fry alrearly attached. With this object in riew, I wonid suggest the use of wooden racks or frames lying horizontally, which would receive the slates into deep notches made with a saw. so as to hold them vertically or edgewise, rendering their removal for the purposes of cleansing and their replacement an easy matter. Other derices would no doubt answer the same purpose and be more convenient even than the last. If posts were securely fixed in the bottom eight or ten feet apart, so as to project a foot or so above the water at the highest tide, a single board six inches wide, nailed against the tops of the posts erlgewise, and extending from one to the other, would provide a simple arrangement from which to hang the slates singly by means of galranized wire fastened or hooked to nails partly driven into the board. By the help of this plan one man with a boat could orerhaul many hundreds of slates in a single day and effectually care for them for a whole season. This last contrivance would not answer weil perhaps where there was a swift current. but would be a most admirable arrangement in still ponds or "claires." in such places the whole area might he provided with posts gromped or placed in rows, so that when the attendant was at work he could pass in order from one row to the other in a narrow boat or two attendants in one boat conld take care of two rows, the ones on either hand at the same time.

As it may be concluded from the foregoing, that the writer would have everything remored from the surface of slates except oysters. he would correct this impression. The intention is not to scrub the slates as a housemaid might scrub a floor to remore erery speck of dirt, but simply to clear off the animals which are rery evidently taking up room to the exchusion of more valued tenants. By some such method as that here described a careful supervision can be accomplished with little out- 
lay and every injurious agency can be watched and destroyed before serious damage is done.

DIFFICULTY OF KEEPING ARTIFICIALLY IMPREGNATED

EGGS ALIVE.

During my sojourn at St. Jerome's Creek, experiments made with a view to keep the young oysters alive which had developed from artificially impregnated eggs, met with no better success than the attempts previously made by Prof. W. K. Brooks. 'The difficulties experienced were the same as those encountered by him, that is, it was found impossible to renew the water on the swimming embryos without losing many of them. Whether the mortality experienced is altogether due to the decomposition of organic material, sudden or violent changes of the temperature and weather, or a want of more freqnent changes of water, I am not prepared to say. Heavy storms no doubt affect the eggs and enthryos very much; sometimes mortally, as Prof. Brooks experience as well as my own would seem to indicate. Floating boxes with muslin bottoms were tried, but with indifferent success, althongh the boxes were covered, violent rains seemed to kill the embryos. The muslin bottom which was employed was soon found to become loaded with organic matter and small organisms, so that it soon became practically impervions to water. The development of minute lite was rapid, and the sides and hottom on the inside were soon covered with a slime loaded with vibriones, monads and infisoria into which the delicate eggs probaloly sank to be smothered or consiamed as food by this mirroscopic host. Repetitions of the experiment met with the same bad snceess, nntil at the suggestion of Major Ferguson a large fiannel pen was constructed into which a quantity of eggs, numbering many millions, were placed. The pen, although so large, 6 feet long. 4 deep and 3 wide, gave results of little more value: though I obtained a single young oyster which fixed itself on 
one of the slates suspended by means of wire from strips extending across the top of the box from one side to the other. It seemed to me, however, that there was little doubt but that the single young oyster found on the slate serenteen days after the spawn had been put into the box, was one of the embryos which had been so introduced. The flannel, like the cotton, becomes befouled in a few days with a muddy deposit held together with a disagreeable sliny material : it, like cotton and bolting cloth, rots in a conple of weeks so as to be easily torn by fishes and other water animals, such as musk-rats. Once the enclosure has been inraded by a larger animal forcing its way through the flannel, as happened in the case of the large box. one can no longer be certain that embryos naturally fertilized in the open maters may not have found their way in. The experiment with the large box was useful however, as showing that enbryo ascidians and barnacles might be pretty effectually excluded by the nse of textile membranes through which the water had to be strained before it could enter the box.

PROPOSED NEW IETHODS OF CARING FOR ARTIFICIALLY

IMPREGMATED EGGS.

Fron this season's experience it results that I have but little fairh in floating boxes or enclosures of any kind in which cloth is used to keep the eggs or embryos confined. Few cloths are evenly and closely enongh woven. if they could be kept clean, to retain in an enclosire eggs as small as the 1-500 of an inch in diameter. which is about the size of those of the oyster. clam, shiy-worm and perhaps nany more marine animals of rarious types, such as embryulogists would be glad to study, provided they had an apmaratus which wonld enable them to work continuolisly.

Finding that what we wanted was a device which would enable the operator to change the water on the embryos and eggrs continuonsly and at the same time not 
run the slightest risk of losing a single egg from leakage, it occurred to me that the proper thing to do would be to constructa box in which the water passed throligh a membrane of blotting or filtering paper into the hatching chamber and out of this again through a similar membrane into another chamber and allowed to escape. In some such way it will be possible to hatch the minutest eggs and watch the reproduction, division, ete., of the very minutest monads. The idea is possibly one of immense practical value in oyster-culture and opens up a field of work in embryology in the pursuit of which many conquests are still to be made.

Another form of apparatus which suggested itself to me during my experiments with the derice just described; has the advantage of being easily operated by some simple form of pump, by means of which the water may be constantly renewed in the hatching chamber. A metal ring with a bibulous membrane on either face, made water-tight around the edges of the ring, so as to enclose a space into which a short piece of tubing may be screwed at one side and connected with a pump by a rubber tube. In this way, by pumping, water would be drawn into the space included by the ring and membranes, provided these were immersed in the water contained in the hatching chamber. Of course, the membranes wonld have to be strengthened both inside and outside by a single thickness of stout canvas, the same as I used in making my experimental boxes, so as to have the bibulous membrane between the sheets of canvas to aroid rupturing the former, by pressure or accident. 'The diameter of the ring and membranes might be six inches, as more than that would probably render the membranes liable to collapse when the pump was in operation. The amount of water passing through the apparatus I shonld think would not need to be more than what wonld completely change the water in the hatching chamber once in every half or one hour, so that the pmmp necessary would be 
one of small capacity, working slowly. Probably enongh rerated water would pass through the hatching chamber by being changed 24 to 48 times in the comrse of 24 hours, to ensure the success of this method of artificially incubating the artificially impregnated eg's. Difficulties might be experienced in keeping the membranes from clogging in the practical conduct of the work of incubation by either of the methods which I have proposed, but this could easily be remedied by filtering the water to be passed through the hatching chambers, through moderately coarse cloths, and by carefully keeping the outer canras corering the membranes clean, and by renewing both canras and membranes from time to time.

The importance and ralue of an apparatus by the help of which the oyster may be artificially hatched and taken care of up to the critical period when the roung larvae fix themselves, can hardly be orer-rated, because if this can be achieved a new lease of life awaits the interests of oyster-culture. There may be difficulties in the way which I have not foreseen. Bnt the importance of the plans proposed and the schemes which depend upon them are so great that I hope to be pardoned for appearing too sanguine in my anticipations of success.

should sucress attend expeliments made in the way abore described. so far as to keep the larrae in a healthy state up to and including the period when they tix themselves. it will be necessary to proride some kind of collecting apparatus which mat be placed in the hatching chamber's after it is ascertained at what age they are reaciy for fixation. It may aiso be necessary some time before the roung are ready to attach themselves to provide them with food by passing unfiltered water into the hatching chamber to aroid staring them, from a hose or vessel, without its haring passed through the incurrent membiane which filters out both the dirt and the food of the roung oysters. The collecting apparatus which has suggested itself to me and which I think might be used 
with good results, should be made of small bunches of cotton wool, strips of undyed cloth, bunches of bristles, sheets of mica, and similar materials which would afford temporary attachments for the fry and which afterwards could be separated when ready to be removed to more commodious quarters cr artificial nurseries. In order to study the manner in which the fry at first fixes itself, it will doubtless be necessary to use cotton wool, thin strips of mica, or glass. It is only by this means that the true character of the attachment can be learned from the objects themselves, brought on to the stage of the microscope in an entirely undisturbed condition. Beyond the period of fixation it would probably not be judicious to retain the fry in the hatching boxes, berause they are now in a condition to feed actively, and should be placed under such conditions in a supply of constantly changing unfiltered water, as will supply them with an abundance of food. 'This brings us to the consideration of

\section{NURSERIES.}

These, I apprehend, would best be made in the form of galvanized wire cages, of $\frac{1}{8}$ inch mesh cloth, inside of which a number of trays might be placed one on top of the other. 'These trays might in fact be made to answer as supports for the collecting apparatus in the hatching boxes, to be afterwards transferred with the affixed spat to the nursery cages. The greatest care would have to be exercised in the care of the very young fry until it was ahout ten days old from the time of fixation. No noxious aninal growths ought to be permitted to grow upon the trays or collecting apparatus if it is possible to prevent it, nor should the fry be exposed for any great length of time to the air, which would no dould he very injurious. The cages if totally immersed should be provided with a wire cloth cover with meshes as fine as those of the sides and bottom in order that carnivoroms fishes and mollusks mày be effectually excluded. A fter 
the young have grown to be $\frac{1}{1}$ to $\frac{1}{2}$ of an inch in diameter they would probably thrive better in a cage made of wire cloths with coarser meshes. Here they should be spread upon trays so as not to encroach upon one another, but the care to keep them from being injured by other growths and enemies should not be abated. Finally, after being cared for until a few months old they would probably be ready to be introduced into the claires or parks, where a clean bottom should be prepared for them upon which they should be sprear, so as not to interfere with each other's growth by being crowded too thickly together on the bottom.

The difficulties about the methods just proposed, are their practicability and cheapness which may be found to be insurmountable obstacles in the way of their success upon being brought into practice. And, I have only taken up so much space with a description of my plans in order that some one else may be able to test them should I be prevented from doing so, as well as to point out a new line of experiment looking to the solution of the difficult problem of the cheap and practical artificial cultivation of our noble American oyster.

OBSERVATIONS AS TO THE SIZE OF THE FRY AT THE TIME OF FIXATION.

Upon examining the hinge of young oysters carefully, it will be noticed that at the very apex of the umbo of either valve there is a rery small rounded prominence. This upon examination with a magnifying power of fifty diameters is found to show faint lines of growth like the other portions of the shell. It corers like a little cap the extreme tip of the ralve and appears to be somewhat raised from the other part of the shell or marked off by a groove which surrounds it. On comparing a great number of young spat we always found these little caplike tips to the valves, and always of about the same size and shape. Remembering that the young of Gaster- 
opod mollusks often in passing into the adult estate cement their larval shell to the bip of the permanent one, it occurred to me that these little cap-like structures on the tips of the umbos of the young oysters, must in like manner be regarded as the shell of the oyster larva at the time it attaches itself to a foreign object. Upon comparing the outlines of the supposed larval shells of our oyster with those shown in a mounted specimen of larval oysters taken from the mantle of the European species, I found the likeness very striking but much larger. These umbonal affixed larval shells measure on the average 1-80 of an inch, which is probably the size of the fry at the time of fixation and are represented in position in Fig. 6 viewed from within, and Fig. 7 from
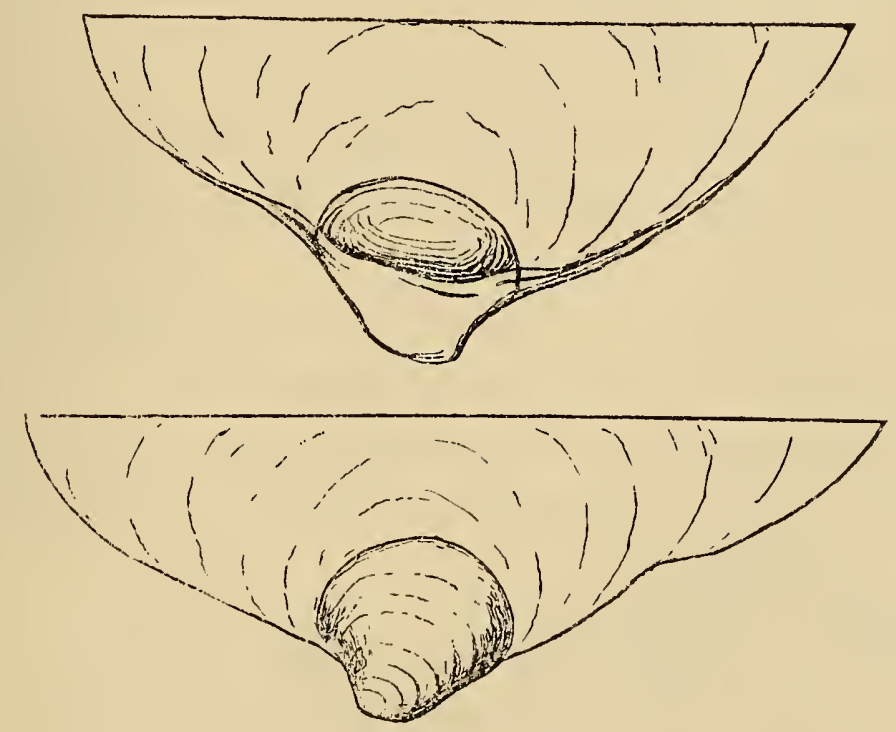

Figures 6 and 7.

without. Previous to attachment, the right and left shells of both the American and the European species are perfectly symmetrical, and it is not until after attachment takes place that the valves show a disposition to become unlike. These larval shells in the spat I have examined are symmetrical, which is almost positive proof that they are really the temporary shelly covering of the fry when about to change its roving habit to 
a stationary one. I nerer failed to find the structure present, which $I$ have just described, on young spat; after a tinie, as the oyster becomes older, the umbonal, portion of the shell together with the larval shell is worn off or is dissolved away by the carbonic acid in solution in the water, so that it is not to be found on the adult shell.

In examining the collection of oyster's in the museum of the Academy of Natural Sciences of Philadelphia, I found that I could very easily detect the presence of this larval shell, and of about the same size, in the "spat" of four other species, viz: Ostrea equestris Say, from Florida; O. conchaphila, California; O. cucullata, Viti Islands, Pacific; a species which was also bored by a Cliona; O. peruviana, Peru. The presence of this feature, together with others, will enable conchologists to distinguish the young from adults, some of the former no doubt having supplied a basis upon which to found species.

THE RATE OF GROW'TH OF THE SPAT.

Upon comparing the spat obtained from our collectors which were put out in the pond at St. Jerome's Creek, with that of the same age as figured ly Coste, and Möbius of the European oyster, I find that our species grows with three or four times the rapidity of the former. For instance, Möbius figures a European oyster twelve to fifteen months old, which measures only $1 \frac{1}{4}$ inches in diameter, contrasting this with the size of the American at 79 to 82 days old and measuring from $1 \frac{3}{4}$ to nearly 2 inches in diameter, we see how immeasurably our species smrpasses that of Enrope in rigor and rapidity of growth.

Fig. 8 shows the single specimen obtained fiom the collectors placed in the large box or flannel pen, and supposed to be one of a lot of artificially impregnated spawn put into the box serenteen Fig. 8 
days previously. It was probably not attached longer than from seven to ten days and is already as large as a young European oyster figured by Möbius as being a month old. I have sketched it both natural size and enlarged about three times to show the tiny larval shell as a sort of rounded point at the apex of the upper valve.

Fig. 9 shows a young oyster supposed to be not over twenty days old, and the one represented in Fig. 10 is known not to be over 44 days Fig. 9. old, Fig. 11 is not over 48, Fig. 12, 79, and Fig. 13, 82 days old. Fig. 14 represents a very fine specimen

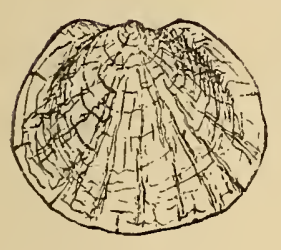

Figure 10.

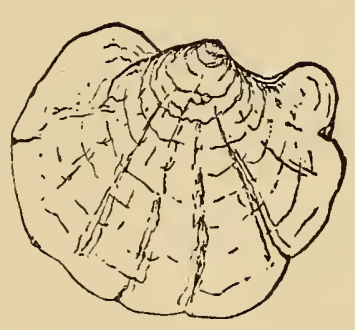

Figure 11.

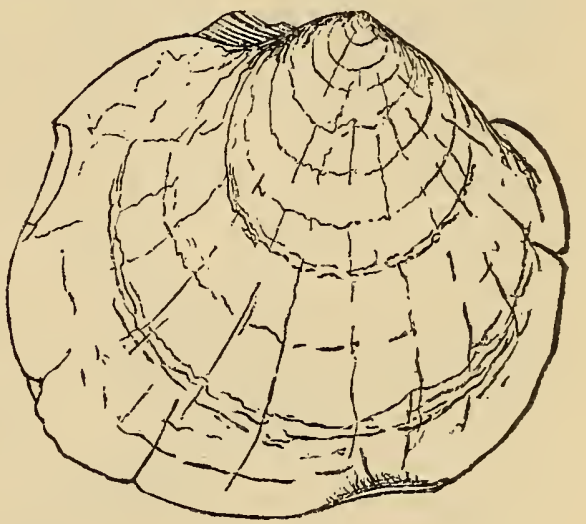

Figure 12.

taken from the inside of a wreck at Cape May, N. J., by my friend Mr. John Ford, and is supposed to be not over

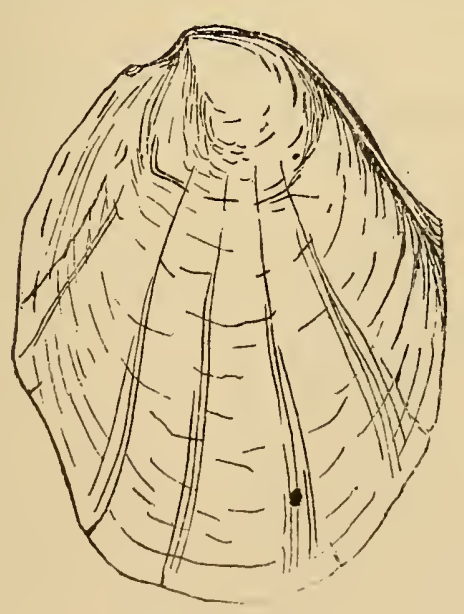

Trigure 13.

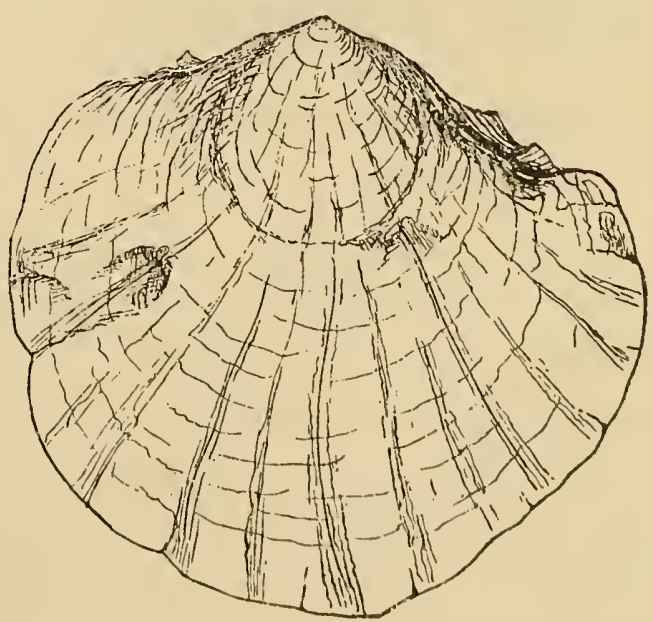

Higure i4.

$2 \frac{1}{2}$ to 3 months old from the fact that it was collected in 
July, while the shell bears every mark to indicate that it probably is of one season's growth, being spawned in the early part of the breeding term.

It will be noticed that all except Fig. 13 are handsomely rounded in shape not unlike a scallop in form, which they simulate still more by the lobes which they develop on the shell on either side of the hinge. Bands of a purplish color also radiate from the hinge, widening towards the margin of the valves, giring the spat a very much more handsome appearance than the adult, from which it difiers also in having an extremely thin shell which is easily crushed or broken. The rounded forms were taken from the Hat surfaces of the slate collectors, though Fig. 13, the only one noticed which exhibited a tendency to elongate like the adult, was taken from a similar surface. If the fry happens to fix itself to a roughened surface or in an angle it will adapt itself to the shape of the nidus which it has chosen. In one case I found a small oyster about a fourth of an inch in diameter attached to the ontside of the plicated shell of a Modiolaria, and was surprised to notice that in growing and adapting itself to the wrinkled surface of its host it had reprodnced in both valves all the folds on the outside of the former. I also found a specimen which had fixed itself to a dead sponge.

NUMBER OF SPAT WHICH FIX THEMSELVES TO A SINGLE SLATE.

As I have remarked above the most successful collecting apparatus was found to be the slates covered with a coating of mortar, but even these did not give the most promising results, as the greatest number of spat noticed on one slate was 8, varying from to 1 inch in diameter. This meagerness in the number of young which fixed themselves last summer may have been due to an unfavorable season. The results obtained by Captain Winslow as detailed in the report of this Commission for the 
season of 1880, wəre much more satisfactory with halfround tiles. Using hurdles or nests numbering 8 to 16 tiles, the results obtained from one placed in the Big Annemessex were very flattering. After it had been immersed 24 days 1506 oysters were counted; after 45 days 1334 ; and after 93 days had elapsed the number still adherent was 539. In size and at corresponding ages these were similar to those which fixed themselves to the slates used at St. Jerome's. From what we know of the number which sometimes fix themselves to a single object we may yet look for great successes in the use of collecting apparatus. In one instance, the inner face of one valve of a dead oyster furnished attachment for over 40 spat from $\frac{1}{8}$ to $\frac{3}{8}$ of an inch in diameter.

CHANGES OF FORM DURING THE GROW'TH OF THE SHELL.

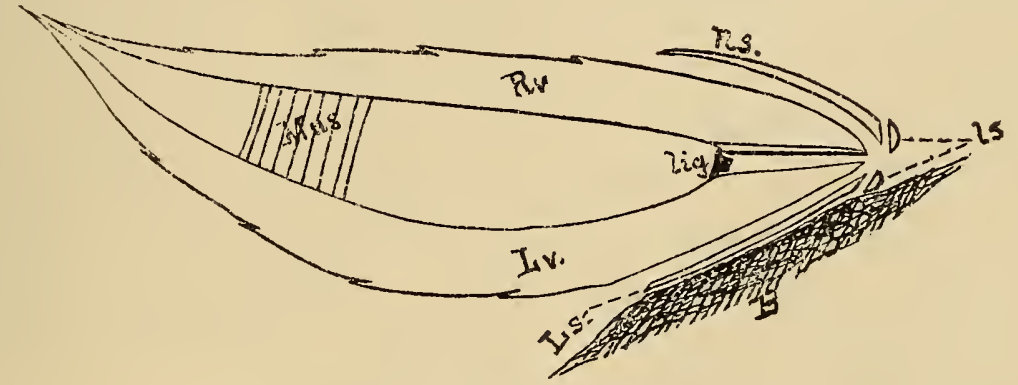

Figure 15.

In Fig. 15 we have attempted to represent the changes of shape and character of the shell of the oyster in passing from the free-swimming larval condition to that of the adult. There are three well marked stages of shellgruwth, viz. : (1) the perfectly symmetrical stage attained by the valves of the "fry ;" (2) the asymmetrical stage of the "spat," and (3) the asymmetrical form assumed by the valves of the adult. In the figure, which is supposed to be a section of the shell with all its parts preserved, cut through lengthwise from the hinge end to the free edges of the valves, we note first, that the shells of the lar'va or "fry" $l s$. are alike in cross-section; that the section of the "spat," which has affixed itself to a sta- 
tionary basis $B$, shows that the right valves R.s. is concave within and convex without, while the attached left valve Ls. is Hat conformably to the character of the basis of fixation. which is most often of this nature. Contrary to what is noted in regard to the shape of the valves in the "spat," the right ralve of the adult $R t$. is nearly flat, while the left one $L v$. is most decidedly concave within and conrex without. Other changes in the more important parts during growth are manilested mainly by the muscle $r u s$., which moves the position of the insertions more towards the free edges of the valves, while the ligament $7 \mathrm{ig}$. is moved in the same direction. Other differences in the forms of the valves at the different stages may be noticed; for instance, the shells of the "fry" are deeply concave and very thin, the valves of the "spat" are still also relatively thin, while it is only the adult which has a very thick, stout shell, though the thickness is said to vary with the depth of the water, the thinnest shelled oysters being found in the deepest water. These (leej-water oyster's are known as "paper-shells" and are not liked by oyster packers and dealers, becanse the valves break very easily in opening them, causing additional labor in their remoral. 'This last fact is evidence in favor of shallow-water culture.

There are good grounds for dividing the growth of the oyster into the three stages already alluded to : the first we nay consider as answering definitely to the free swimming rondition or that of the "fry :" the second the thin-shelled primary fixed condition or that of the "spat:" the thind, that of the adult, which alleady has a pretty thick shell when a year oln, when the generative organs ton are in aldive functional use, a circumstance which has also heen noticed by writers om the life-history of the ovitel of Euroge. 


\section{Introductory Note to Mr. Winslow's Paper.}

[This paper is a desirable contribution to the literature of embryology, inasmuch as the observer has been able to follow the development of Ostrea edulis from its earliest phases, which has never been done before by any embryologist, although the artificial impregnation of the eggs was attempted by M. Davaine, who says he failed, and that the eggs soon became putrid and the water containing them swarmed with infusoria. M. Davaine's figures bear the marks of having been carefully made from close observations, but he obtained his material from the upper gill chamber, where the ova had already undergone all the changes represented from Figs. 1 to 16 of Brook's drawings of the early stages of the American species. Many things have accordingly escaped the notice of the French author, who did not see the "polar globules ;" the first and second periods of rest and activity at all. He also failed to recognize in the embryos with the dorsal saddle-like depression, a blastopore stage and the epibolic invagination of the hypoblast. He, however, finds that the shell originates in the position of the blastopore, as shown by Brooks. He states that the velum atrophies with the development of the mantle and gills, but does not describe the latter. He does not note the presence of a membrane around the ovarian egg, and it seems to me the membrane is a continuation of the vitelline, which forms a stalk by which the ovum is attached to the walls of the follicles of the ovary, making a channel for the passage of plasma for the growth of the ovum, as suggested by Balfour. 
Mr. Winslow's paper was first offered to the Maryland Academy of Sciences for publication, but was declined on account of a want of funds to publish it, when it was offered to Maj. Ferguson, one of the Commissioners of Fisheries of Maryland, who accepted it for publication in the annual report of the Commission for 1881. It will be noticed that the author makes no claim as to his ability as an accomplished embryologist, but the observations he has made are very important, as showing that the eggs of Ostrea edulis can be artificially fertilized and their development watched the same as our own species.]

J. A. R. 


\section{An Account of an Experiment in Artificlaly Fertilining the Ora of the Europenn Oyster (Ostrea edulis.)}

Having been engaged during the summers of 1878-9 under the direction of the U. S. Coast and Geodetic Survey upon an investigation of the oyster beds of Chesapeake Bay, and having devoted some attention to the biology of the American oyster during those seasons, such study being an incidental and partially a necessary portion of my work, I have been lead, by the interest awakened by my previous labors, and by Dr. Brooks' late.successful experiment in artificially impregnating the ova of the American oyster, to attempt a like experiment with the European species. While the ressel to which I am at present attached was off Cadiz, Spain, I was so fortunate as to obtain about one hundred oysters fit for fertilization from the waters of the Bay of Cadiz, and my experiment having been successful beyond my expectations, I have concluded to lay the record of it before the Maryland Academy of Sciences, thinking that any information regarding the oyster, whether of the European or American species, conld not fail to be of interest to the Academy. During the summer of 1879 I had the pleasure of witnessing the experiments of Dr. Brooks, which he has detailed in his paper upon the Development of the American Oyster, and with which the Academy is doubtless familial, and in conducting my own experiment I have followed his method as nearly as possible, and have used his figures in describing the development of the European animal. I can therefore lay no claim to originality in either the conception or execution of the experiment which I undertook, and I am but a follower in Dr. Brooks' footsteps. As however, this is, so far as I am aware, the 
first attempt to artificially impregnate the eggs of the European orster, and as the inferences which can be logically drawn from its success affect the theory of the reproduction of the animal and the derelopment of its eggs to the same extent as those drawn from like successful experiments affect our own species, I have thought my work might prove both of interest and of value.

I labored under many disadrantages, and with a very inferior microscope, though magnifying 300 diameters, of obsolete pattern, and at times had to contend with the irregular motion of a vessel at sea and the deficient light afforded by lamps. All my appliances were such as I could obtain or improrise on board ship, and their rudeness and the inconrenience they caused hampered me a good deal in conducting the experiment. I regret that my observations were not more systematic, regular and frequent, but a naval officer has but few moments which he can safely call his own, and my official duties necessarily compelled $m y$ freqnent and prolonged absence from the microscope.

\section{HISTORY OF THE EXPERIMENT.}

The oysters were obtained from the mouth of St. Mary's River, in the Bay of Cadiz, Spain, and were natives, the variety having existed and flourished in the Bay for as far back as conld be remembered. In appearance they were quite similar to the American species (Ostrea virginiana), haring long shells of from one to three inches in length, rougher and thicker than is usually the case with the European oyster ; there were no clusters however, all the animals growing singly, and but a very few young of the prerious season were attached to the shells; those noticed were probably nine or ten months old, and though certainly of the brood of the previous season were small sized when compared with the American oyster of the same age. The adults were about the size and 
of the appearance of the Chesapeake Bay oyster when about two years old. The animals when divested of their shells were larger than those of the same species from other localities, and were all in good condition, the ova and spermatozoa being ripe, in many cases oozing from the oviducts, and in all cases in admirable condition for artificial fertilization, the eggs being well defined, and with but little granular matter among them, while the spermatozoa were exceedingly active.

I had intended to examine carefully the ovaries, gills and mantles of all the oysters at my disposal with the intention of detecting the existence, should there be any embryos within the shell, but the pressure of other duties and the disadvantages under which I labored left me but little time and few opportunities to devote to the matter, and consequently I am unable to state positively that in some among the limited number in my possession, the embroys were not fostered within the shell of the parent. I was able to examine between twenty and thirty oysters only ; these at least contained no embryos, though some of them were expelling the contents of the generative organs, as I found on the gills of two, ova unimpregnated, and on the gills of another, spermatozoa.

In making the experiment I followed carefully the method of Dr. W. K. Brooks, as described by him in his paper on the development of the Americon oyster, (Report of the Commissioners of Fisheries of Maryland, 1880 ,) and I am compelled to refer to his figures, given in that report, from the want of suitable instruments and conveniences for making those of my own. As I care fully followed the development of the eggs through each stage, comparing those under the microscope with the figures at frequent intervals, as the successive stages of development are well marked, and as I have witnessed many of them in company with Dr. Brooks, and have likewise observed them while working independently during the summer of 1879 , I think my observations may 
be relied upon and assigned a greater ralue than those of most amatemrs.

THE ARTIFICIA IIPREGIATIOX OF THE EGG.

Two ripe males were selected. the spermatozoa from which was very actire. and the risceral mass was cut ont : all parts of the digestire organs were then remored, learing the generative prodncts in the saucer. The latter were then chopped up as finely as possible and mixed with salt water: and the fragments of the digestive organs. mantles and gills carefully washed out, and this process was repeated sereral times until the male fluid was free from all deleterious matter. Two female oysters were then treated in a like manner. and finally both male and female fluids were mixed thoroughly in a glass holding one half pint of rlean salt water. The fertilization was accomplished at 8.0.5 P. M. on on 6 the The following are the noted times of the principle changes during the process of segmentation and subsequent derelopment :

8.12 P. M. The eggs were irregular in shape and corered with spermatozoa-germinative resicle plainly risible-appearance exactly as figured by Brooks. (Report Com. Fisheries. Maryland-Pl. VIII-Fig. 51.

8.32 P. M. Germinative resicle had disappeared and egg's nearly similar to Brook's fig. .2. thongh not so regular in outline.

The water was now siphoned off and the glass half filled with fresh sea-watel.

10.10:3 P. M. One hour and tifty-three minutes after. fertilization. the eggs had become elongated. and the polar globule was easily observed. In a few eggs the separation of the micromeres and macromeres could be distinguished. The appearance of the eg's was as is shown in Brook's figs. 2. 3, 4 and 5, the larger number resembling figs. 2 and 3.

At 11.10, about three hours after fertilization. all the 
eggs examined had passed through the first stage of activity, and as far as could be decided had reached the second period of rest-resembling Brook's figs. 8, 9 and 10. I was called away from the microscope at this time and was unable to trace the changes during the second period of rest or to note the time of their occurrence.

At 1.27 A. M., or five hours and fifteen minutes after fertilization, the eggs had passed through the second period of activity and had entered upon the third period of rest. In some of them the four micromeres were easily observed, but in others they were not so distinct; a few were as figured by Brook's (fig. 16), but the majority appeared as in figs. 18 and 19 .

I was unable to follow the intermediate changes between those of the third period of rest and those of the first swimming stage, but at my next observation, at 4.30 A. M., on the 7th, larger numbers of eggrs had reached the latter stage and were swimming at the surface of the water. The cilia were well developed and the movements of the embryo very rapid-their appearance was exactly as figured by Brooks' figs., 32, 33, 34 and 35. The water in the glass was now siphoned off, into a jar, that the embryo might have room for development and be free from the influence of decaying eggs; but as I had but two fruit jars holding a quart each, with which to conduct my experiment, I was forced to take many eggs into the second receptacle before they had developed swimming powers, or else sacrifice them. As the rate of segmentation was very irregular, I had for a time, what was to me, a rather confusing mixture of eggs in the process of segmentation and developing embryos ; but with care and close observation, I managed to follow each lot until they reached the swimming stage and could observe no difference between them and the first, except in the rate of change from one period to another.

At 12.30 P. M., June 7th, or sixteen and a-half hours after fertilization, there were many eggs in the first swim- 
ming stage, but the majority had only reached the later periods of segmentation, appearing as figured by Brooks, in Nos. 25, 26, 27.

At $8.00 \mathrm{P}$. M., there were large numbers in the first swimming stage at the surface of the water, the cilia were well defined and active; in many cases the polar globule was still observable. The majority of the embryos appeared as figured by Brooks, in Nos. 32, 34 and 35, while a few were in more advanced stages, appearing as in 36 and 37. The pressure of other duties prevented my continuance of the observations after 11 P. M. until 11 A. M. on the Sth. At that time the majority of the embryos were as figured in Nos. 36, 37 and 38, the latter stage predominating. The shell was remarkably well defined in several, but the activity of the embryo and the rudeness of the instrument used, prevented my deciding with certainty as to the extent of the development of the digestive tract or the presence of either the mouth or anus.

At 11 P. M., on the Sth, or two days and three hours after fertilization, I found one embryo that so exactly resembled figure 36 , that it might have been the original from which the figure was drawn. About this time I experienced ny first difficulty in finding specimens, but my observation of those embryos discovered was very careful and close, and I have no doubt that their development so far was similar to that of our own species. Subsequent to this time, the intervals between my observations were greater, owing to the necessity of my employment upon other duty ; and my absence from the vessel compelled me to put the embryos under the care of others ; consequently in the intervening hours, changes may have occurred which are unknown to me, and many of the embryos may have advanced beyond the latest stages which came under my observation, but so far as I know, none advanced beyond those stages figured by Brooks. 
At 3.00 P. M., on the 9th, or two days and nineteen hours after fertilization, owing to the increased amount of water in the jar ( $\mathrm{I}$ had by this time obtained a large one,) and to the mortality among the embryos, I found it very difficult to find any, and this difficulty was a constantly increasing one thence forward. Those specimens obtained had well developed shells, and the digestive tract could be readily distinguished, as conld the cilia. The movements of the embryo were so rapid and erratic that I found great difficulty in keeping them under the high power for a sufficient time to decide as to the stage they had reached, but those least advanced appeared as figured by Brooks, in No. 38, while the older embryos presented the characteristics of figs. 39 and 42.

At 11 P. M., on the 10th, or form days and three hours after fertilization, the digestive tract and shells were readily distinguished, especially the latter, which were very apparent. The anus was observed in several cases and the course of the intestine from it to the stomach easily traced. The cilia of the relum was also apparent, even with the low power. The main features at this time were similar to those of figs. 42 and 44 .

At 11.00 P. M., on the 12th, or six days and three hours after fertilization, the embryo had apparentiy nndergone little or no change, except that a much larger number had reached the stage shown in figure 44 . In all, the shells and digestive organs were well developed and apparent, and the movenient of the cilia of the relum regular and rapid, though the cilia appeared to have decreased in size.

At 11.00 P. M., on the 13th, seven days and three hours after fertilization, there was no apparent change in those embryos that could be found. They appeared quite healthy and were rapid in their movements. The difficulty of obtaining specintens, however, had much increased.

At 11.00 P. M., on the 14th, eight days and three hours 
after fertilization, I could only find a very few embryos after a long, patient and careful search, which occupied several hours. Those discovered were similar in all respects to those last described, and as figured by Brooks, in No. 44.

On the 15 th, I met with a total failure in my search for the embryos, and it was both long and carefully conducted, and the same want of success attended me on the 16 th, when I gave up the attempt to further trace the derelopment.

It will be observed that I could not find any embryos of a more advanced stage than those figured by Brooks, and that owing, probably, to the irregular rate of segmentation, I found them at the latter stages at periods varying from three to eight days.

It is not probable that the disappearance of the embryo was due to a deficient supply of water, for during the latter days of their existence they were far more liberally supplied than before. Neither is it probably due to change of temperature, for, as will be seen by the following tables of maximum and minimum temperatures, the range of temperature was about the same throughout the eight days :

$\begin{array}{cccc}\text { Date. } & \text { Max. Temp. } & \text { Min. Temp. } & \text { Diff. } \\ 6 & 71^{\circ} & 70^{\circ} & 1^{\circ} \\ 7 & 71^{\circ} & 64^{\circ} & 7^{\circ} \\ 8 & 73^{\circ} & 64^{\circ} & 9^{\circ} \\ 9 & 79^{\circ} & 60^{\circ} & 9^{\circ} \\ 10 & 75^{\circ} & 62^{\circ} & 13^{\circ} \\ 11 & 74^{\circ} & 60^{\circ} & 14^{\circ} \\ 12 & 71^{\circ} & 61^{\circ} & 10^{\circ} \\ 13 & 77^{\circ} & 64^{\circ} & 13^{\circ} \\ 14 & 75^{\circ} & 66^{\circ} & 9^{\circ} \\ 15 & 72^{\circ} & 64^{\circ} & 8^{\circ}\end{array}$

The water supplied to the embryos was always allowed to stand a sufficient time to acquire the temperature of the air before being added to that already in the jar. 
It is a coincidence at least worthy of notice, that with both species the embryos have disappeared at about the same stage of development.

All published accounts of the development of the European oyster agree in asserting or assuming that the impregnation of the ova occurs while they are either within the ovaries or shell of the parent, and that consequently artificial fertilization is impossible; this supposition my experiment effectually disproves. Again, should the artificial fertilization of the eggs and subsequent care of the embryo of the American species reach such a state of perfection as to make the process an addition to oyster culture, and one of practical importance, the agreement of the European species with our own in the early stages of development, will indicate a method by which the supply of oysters may be increased in localities whose need is even now far greater than onx own.

In conclusion, I must express my indebtedness to the paper of Dr. Brooks upon the development of the American oyster, to which I have alluded, and without which I should have been somewhat at a loss for a means of registering the various changes which I witnessed in the development of the European oyster.

Respectfully, FRANCIS WINSLOW, Master U. S. Navy.

U. S. Ship "Saratoga," at Sea; July 5th, 1880. 


\section{BIBLIOURAPHY OF LITERATURE RELATING TO OYSTER CULTURE.}

Arcana Natura detecta ab Antonio Van Leeuwenhoek, 8 vo., Lugduni-Batavorum. MDCXCV.

The antiquated memoirs of Willis, 1672 ; Lister, 1678 ; Jac. Brach, 1689, are now more curious than useful. Méry, (Mém. de l'Acad. des Sciences, 1710 :) Adanson, (Histoire Naturelle des Cuquillages;) and Joh. Baster, 1762, considered the oyster hermaphrodite. Th. Sprat in 1669 compared the fry to a drop of melted tallow which had fallen on a solid body aud hardened, remarking also that it commenced to form a shell in 24 hrs. M. Deshayes, in 1846, was the first to indicate the true position of the reproductive organs. Little exact knowledge had been acquired, however, previous to the time of Davaine, Lacaze-Duthier's and Coste, from 1852 to 1857. To Leeuwenhoek belongs the honor, however, of having made the discovery of the existence of spermatozoa; he believed moreover, that the sexes were separate, a conclusion which is now well gronded so far as the American oyster is concerned, while it is apparently to a great extent true of the species which the famous inventor of the microscope studied nearly 200 years ago.

Testacea Utriusque Siciliâe eorumque Historia et Anatome. J. Poli. Folio. Parma 1791-95.

On the propagation of the common oyster and the large fresh-water muscle. Croonian Lecture for 1826, by Sir Everard Home. Phil. Trans., 1826, 4 to., pp. 39-48, pls. III.--VI.

De Danske ästersbanker, H. Kröyer. Kjöbenhavn, 1837.

Recherches sur la Génération des Huitres. Par C. 
Davaine. Mém. de la Soc. de Biologie. t. IV. 1 e Ser. 1852, 8 vo., pp. 295-339. pls. II. Paris.

Organes génitaux des Acéphales Lamellibranches. par H. Lacaze-Duthiers. Ann. des Sc. Naturelles. 1854.

Mémoires sur le Système Nerveux des Mollusques Acéphales Lamellibranches ou Bivalves. Par M. Duvernoy. Mém. de l'Académie des Sciences, de l'Institut de France. t. XXIV., 4 to., pp. 210, pls. 13-Paris, 1854. (The most elaborate treatise on the nervous systems of bivalves.)

Des organes de la génération de l'huitre. H. LacazeDuthiers. Comptes rendus. tome XL. 1855. pp. 415-420.

Guide Practique de l'Ostréiculture. Par Prof. Felix Fraiche.

History of the Oyster and Oyster Fisheries. By T. C. Eyton, London, 1858.

Voyage d'Exploration sur le Littoral de la France et de l'Italie. par P. Coste. 4 to., 2 Éd. Paris, 1861.

Mind in Nature; or the origin of life, and the mode of development of Animals. By Henry James Clark, 8 ro., pp. 322, D. Appleton \& Co., New York, 1865. (Discusses the Anatomy of the Oyster.)

Etudes sur l'industrie huitrière des Etats Unis. par P. de Broca. Paris, 1865.

Report on the Oyster and Mussel Fisheries of France made to the Board of Trade by Cholmondeley Pennel, Inspector of Oyster Fisheries. London, 1868.

Notizen über Austern-Cultur. von Richard Ritter von Ergo. (6 maps.) 8 vo., pp. 5\%. Triest, Buchdruckerei des Oesterreichischen Lloyd, 1869.

Den Konstige östersavl og den Sudförelse i Danmark. F. Krogh. Hadersleben, 1870.

Ueber Austern and Miesmuschelzucht und die Hebung derselben an den norddeutschen Küsten. von Dr. Karl Möbius (19 wood-cuts.) Sm. 8 vo., Weigandt, Hempel \& Parey. Berlin, 1870. 
Report of the Commission appointed to examine into the Methods of Oyster Culture in the United Kingdom and in France, with a view to the Introduction of Improved Methods of Culture of the Oyster in Ireland. 1870.

Untersuchmngen uber die FortphanzungsverhäItnisse der Schleswigschen Austern. von Carl Möbins. Nachr. d. deutchen malak. Gesellsch., IIT. pp. 129. Frankfurt, a. M. 1871.

Die Austernzucht nnd Seetisherie in Frankreich und England. von A. Tolle. Sm. 8 vo. Berlin, 1871.

Om östersfiskeriet i Limfjorden. Af. J.. Collin.(With a chart of the oyster banks.) Kopenhagen, 1872.

Observations on the Food and Reproductive Organs of Ostrea Virginiana, with some account of Bucephalus Cuculus. By Prof. John MeCrady, Proc. Bost. Soc. Nat. Hist. 1873.

Report on the condition of the sea-tisheries of the South Coast of New Fngland in $18 \% 1$ and 187\%. Wash; ington, United States Fish Commission Report, 1873: (Oyster-beds, p. 472, by A. E. Verrill.)

Bemerkungen neber Haeckel's Gastraea-Theorie.-von Prof. W. Salensky, Arch. fur Naturgeschichte, XI.; 2 Hft:- Perlin, 18\%4. (Figures some embryo oysters.)

Notice sur la situation de l'ostréiculture en 1876.(Extr. de la Rerne maritime et coloniale.) Paris. 1875.

Om vore Haves Naturforhold med Hensyn til Konstig östersavl og om de i den Henseende amstillede Forsög. G. Winther. Kopenhagen. 1876.

Report from the select Comnittee on Oyster Fisheries; together with the Proceedings of the Committee, minutes of evidence, Appendix and Index. Ordered to be printed by the House of Commons. July, 1876.

7. Gerbe, in Zoological Record, 1876, XIII., MoI. 62. [This author states, according to Fischer, (Mannel de 
Conchyliologie, ) that the velum of the embryo becomes the palps of postembryonic life.]

How can the Cultivation of the Oyster, especially on the German Coast, be made permanently profitable.(Rept. U. S. Commission for 1876-'77), 8 vo., pp. 875884. Translation by H. Jacobson of an Address made at the German Fishery Association, 1876, by Karl Möbius, from Circular No. 3 of the Deutsche Fischerie Verein, Berlin, Mar. 21, $187 \%$.

Rapport addressé an Ministre de la Marine et des Colonies sur l'Ostréiculture. par M. G. Bonchon-Brandely. (Publie dans le Journal Officiel de la République Française, le 22. Janvier, 1877.

Die Auster und die Ansternwirthschaft. von Karl Möbius. (One map and nine wood-cuts.) Sm. 8 vo., pp. 126 Berlin. Weigandt, Hempel \& Parey. $187 \%$.

Notice sur l'huitre Portugaise et Française, cultivée dans la Baie d'Arcachon. par .J. Renand. 4 to pp. 33. Arcachon, 1878.

Rapport an Ministre de l'instruction publique sur la pisciculture en France et ostreiculture dans la Mediterranée. Par Bouchon-Brandeley, \& ro., p. 113. Wittersheim \& Cie, Paris, 1878.

La Pisciculture et les Parcs à Coquillages de la rade de Toulon. Par L. Turrell. In Bull. de la Soc. d'acclimation, Paris, 1878.

Translation of a Report made to the Minister of Marine in France, by M. G. Bouchon-Brandely, relative to Oyster Culture on the shores of the Channel and of the Ocean. [Not able to supply the date and place of publication.]

A number of articles on the tools used in taking and rearing oysters, as well as figures of patented apparatus, are given in the octaro report of the U. S. Fish Commission for 1878. Washington, 1880 .

The Development of the American Oyster. (Ostrea Virginiana List.) By W. K. Brooks, Associate in Biol- 
ogy. Johns Hopkins University. 8 ro., pp. S1, pls. X. (In Report of Commissioners of Fisheries of Maryland, 1880.)

The same, published as Contribution No. IV, of Chesapeake Zoological Laboratory, Johns Hopkins University, (a reprint of the preceding) with a paper added. entitled: The Acquisition and Loss of a Food-Tolk in Molluscan-Eggs, 8 vo., pp. 107-116, pl. XI. John Murphy \& Co., Baltimore, 1880. 


\section{$\mathrm{N} \quad \mathrm{O} \quad \mathrm{T} \quad \mathrm{E} \quad \mathrm{S}$}

ON SOME OF THE

\section{FAIXIXEIAGTE}

$\mathrm{OH}$

\section{DEVELOPMENT OF THE CLAM,}

Or MANANOSE.

(Mya arenaria Linn.)

BY

J OH N A R Y D E R . 



\section{NOTES ON SOME OF THE EARLY STAGES OF DEVEL- OPMENT OF THE CLAM OR MANANOSE (My a arenaria.)}

The spawning period of this mollusk lasts from the 10th of September to about the middle of October, or for about forty days. The sex of the adults, in a spawning condition, may be very easily learned. Open the shell of the animal carefully, remove a small portion of the richly colored yellow body mass with a knife, scissors or forceps. These fragments, squeezed or "teased out" in a watch-glass with a few drops of sea-water, allow a milky fluid to escape. Under a magnifying power of four or five times, the eggs of the female are visible in this milky fluid as very minute white points of nearly uniform size. The male cells are too small to be seen with the aid of so low a magnifying power, and the fluid retains its milky apqearance just as it does to the naked eye. It is only under high powers, as much as 250 diameters, with the compound microscope, that the spermatozoa or male cells may be made visible, as minute oval bodies with a long, lash-like tail in rapid motion. These differences enable the operator to distinguish the sexes, after a little experience; indeed, it is possible with training, to note the differences between the male fluid and the eggs of the female when removed from the animals, with the naked eye.

Artificial impregnation of the eggs was effected in the same way as in the case of the oyster; that is, portions of the ripe ovary of the female are removed and chopped up in a watch-glass or small sancer with sea-water, taking care to remove all the large fragments of ovarian tissue by straining the milky substance through bolting cloth, 
which will allow little else than the eggs to pass through its meshes. The spermaries of the ripe males are treated in the same way in another saucer, after which the male cells mixed with sea-water may be poured into the dish containing the eggs. In two or three hours after the water containing the male cells has been poured over the eggs, development will have begun. The water should now be removed from time to time by pouring it out of the dish or tumbler, taking care not to stir up the eggs which have settled to the bottom. Soon, however, the embryos will begin to swim, when it will be necessary to remove the water in another way, or with the siphon.

The changes which occur in the eggs during development, succeed each other with considerable rapidity, and, as in the development of the oyster, there are very well-marked periods of active change of form, which alternate with periods of repose, while there is a bilateral symmetry which is just as well marked as in the latter and Unio. A power of 250 diameters enlarges the eggs satisfactorily; shows the freshly impregnated eggs as spheres measuring $\frac{1}{2}$ inch in apparent diameter, a proof that the actual diameter of the egg's is very nearly 1-500th of an inch. The eggs are not spherical when first removed from the ovary, but are usually irregular in form with a more or less well pronounced conical extremity, by which they were attached to the walls of the ovarian follicles. The other end is more or less irregularly rounded. A nucleus is plainly visible during this irregular stage, but no well defined egg-membrane is apparent.

The early stages which I was enabled to figure may not entirely cover the different phases through which the embryos pass at that time, but in view of the circumstance that there is but little known of the development of Lamellibranchiate or bivalve mollusks, and that little relates to but few forms, I feel justified in offering the results obtained from a study of the embryonic development of the Clam, which has not been studied hitherto. Though 
I did not succeed in following the development farther than to the formation of a gastrula, and was not able to time the changes which were observed, owing to the fact that my watch was broken. I still hope to be able to make a series of observations which will include the later stages.

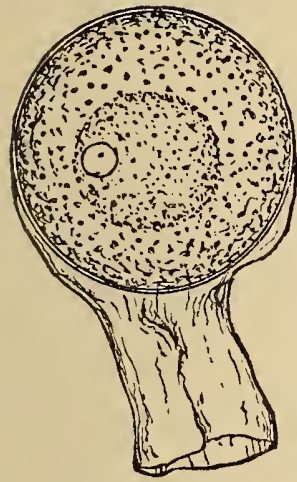

Fig. 1 shows an egg which has been removed for some time from the ovary; the vitellus composed of minute corpuscles or spherules has assumed a rounded form, a nucleus is still visible as well as a clear nucleolus within it; the vitelline membrane has become defined, while the delicate thin membrane which held the eggs fast to the wall of the ovarian follicle re-

Figure 1. mains attached as a transparent structureless film. It is the supposition, based upon the conclusions of other observers, that at this stage impregnation has not yet been effected. This is effected by the entrance of a single spormatozoan or male cell into the egg through the vitelline membrane, but as I have not noted a micropyle, either in the eggs of this animal or that of the oyster, it is very probable that the male cell finds its way into the vitellus through an opening in the vitelline membrane extemporized for its passage. We are, at any rate, not yet ready for a general conclusion as to the presence or absence of a micropyle in the Lamellibranchiate cvum, to which Balfour in his Comparative Embryology, Vol. I., p. 31, commits himself. The histology of the ovaries of more forms must be studied before we can decide, and no more promising field is open before us than the investigation of the ovogenesis of the oyster and clam, both of which are still unstudied in relation to this point. 
Fig. 2 represents an egg of the clam after the lapse of perhaps two hours from the time it was first brought into contact with the male cell ; it has apparently been impregnated, for the nucleus and nucleolus are no longer visible. It has also beHigure 2. come perfectly spherical and has lost the membranous, filmy appendage of Fig. 1.

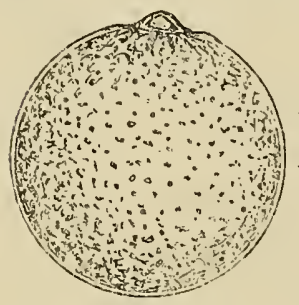

Fig. 3 exhibits the same egg still later when the first polar cell has appeared as a minute blister-like prominence at one side. The polar cell is almost transparent and is situated in a slight depression, from which

Figure 3. impressed lines radiate, making it appear as if the vitelline membrane were wrinkled in a radial manner. A sinilar radial wrinkling around the polar area is described by Whitman as occuring during the formation of the polar cells of the egg of a small freshwater leech (Clepsine), but it is more strongly marked than in the egg of the clam. I have not noted this radial wrinkling in the egg of the oyster. After a while the egg represented in Fig. 3 undergoes farther change, a series of annular waves pass from the pole of the egg opposite the polar cell and a second polar cell is pushed ont, when the radial wrinkles disappear and the polar cells present the appearance of two small spheres joined to each other and attached to the egg by a stalk as in Fig. 5. I shonld have stated before that the first polar cell originates in the same way as the second-by the passage of a series of waves from one pole to the other. These are not all of the forces that are at work in the extrusion of the polar cell; the nucleus of the egg has been undergoing changes of form, elongating and contracting, disappearing to assume a spindle form, then contracts into a rounded form, but with one end in intimate relation with the polar cells. These changes of 
form seem to constantly accompany the expression of all the phenomena of active change in living cells, such as growth and division. Networks have been described in nuclei; the latter are known to expand and contract; elongate in the direction of certain lines of force; again withdraw into a globular form, so that Flemming has proposed the terms diastole and systole for these wonderful phenomena, which suggest, if they do not prove, the existence of forces of repulsion and attraction in active labor in the heart of every living cell. We have these phenomena presenting themselves to our vision in the eggs of the oyster and clam. The protoplasm of the egg' tremulous with an intense life pent up and energetically trying to unfold itself soon causes the vitelline membrane to quiver and work in rolling waves and the egg assumes very rapidly the form shown in Fig. 4 as seen from below, and Fig. 5 as seen from the side. The two centres of force or nuclei are here indicated as two small clear spheres near the central part of the two cells which have been defined by a period of activity just past. The forces of growth now remain qui- Figure 4.

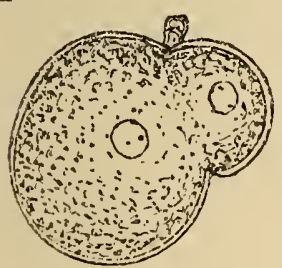

escent for a space, to be exhibited in one of their supremest moments of activity in Fig. 6, in which a portion of the largest cell or megamere is being separted to form a smaller cell or micromere. At the same

Figure 5. time what was the small cell or micromere in Fig. 5 is as energetically dividing into two smaller cells or micromeres. The result is three micromeres. Looking nore closely at the figure we see what appear to be lines of force running from the faintly marked nuclei of each of two Figure 6. cells to that of two others. The nucleus of the large cell is in vital relation with that which is budding from 
it. So too, are the two small ones originating from the smaller cell of the stage shown in Fig 5. The notch which is moring inwards to nip off the small cell from the large one moves so fast that I find the camera lucida of use only so far as it enables me to get the dimensions. In like manner the contour lines on the other side are rapidly changing in the division of the smaller cell.

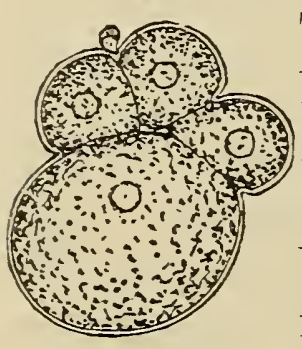

Then follows a condition of rest shown in Fig. 7. The micromeres are now three in number, the megamere is still much greater in bulk than all three. The nuclei again become defined. The egg is passing slowly into the stage shown in Fig. 8, at the one

Figure 7. pole of which we still see the polar cells persisting. The three micromeres have subsided: become depressed and the whole outline is more roumded, like that of the unsegmented egg. The faint indication of a segmentation cavity or space shown between the micromeres and megamere in Fig. 7. has disappeared. The embryo is Figures. quiescent and has reached the limit of perhaps its third or fourth period of activity and rest. The succeeding

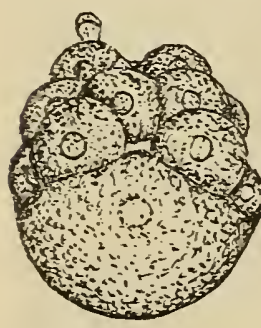
stage represented in Fig. 9 is where the next period of actirity has reached its completion. The micromeres of Figs. 7 and 8 have again divided and one or two micromeres have been derived from the megamere; in this way a number of additional micromeres

Figure 9. has been the result. The micromeres are now piled up at one side, or rather end, of the egg, and the polar cells still persist. The micromeres display a certain symmetry of arrangement. It now becomes apparent that the micromeres are to be the foundation of the epiblast or skin layer of the embryo, while the micromere is to become the hypoblast or inner layer from 
which the stomach and intestine is to be developed. In Fig. 9 the micromeres are slowly creeping down over the megamere which is finally enclosed by the former growing in a single layer from above downwards. This mode of developing a two layered stage of the embryo is known as epiboly, meaning that the epiblast grows over and upon the hypoblast which is here represented by the megamere. The megamere is finally pushed inwards and covered by the micromeres or cells of the epiblast. Once fairly inside and included by the epiblast as shown in Fig. 10, the megamere begins to divide as shown by the darkly shaded cells in the lower part of the figure. A depression appears in the middle of this cluster of cells which must, on anatomical grounds, be con- Figure 10. sidered the orifice of invagination of the hypoblast. This orifice or blastopore may be considered the mouth of the so-called gastrula or stomach-stage of development, but it is never used as an inlet for food, which is not yet usable by the larva. The depression however persists, and there is every reason to believe that, like in the oyster and fresh-water mussel, it is the point where the shellgland of the embryo develops and that it therefore marks the position of the back of the animal. Fig. 10 also illustrates plainly the position of the outside skin layer or epiblast Ep., from which the mantle, gills, and siphons of the adult are derived, and its relation to the darkly shaded hypoblast cells $H y$. inside, which finally become fully covered by the epiblast so as to appear like a cluster of cells in the inside of the hollow sphere formed by the latter. The central cluster may now be looked upon as the archenteron or primitive foundation from which a true stomach is derived.

The way in which the gastrula stage of the clam is formed is so far unquestionably the same as that of the oyster ; what lies beyond we cannot say, but it is in the highest degree probable that the history of its later stages 
is much like that of the latter. Since we have been led along so far it will perhaps be profitable to inquire into the next phase of the oyster as throwing light upon the origination of the permanent mouth, stomach and intestines. Fig. 11, which I have copied from Salesnky, rep-

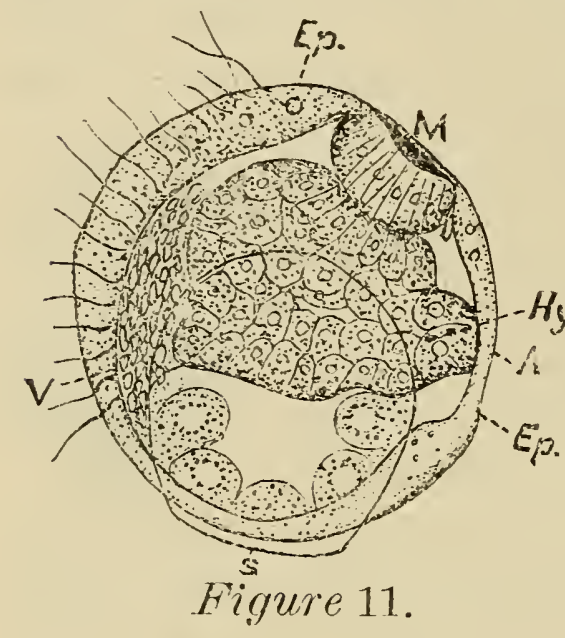
resents the larva of the European oyster at a stage considerably farther advanced than my Fig. 10 of the clam. I have inverted the original and ychanged the lettering somewhat, in order to make the figure correspond in position and to make the names of the parts agree with the nomenclature which I use.

The depression at $H y$. in Fig. 10, has disappeared in Fig. 11 and the shell $S$ corers the spot. It will be noticed too, that the hypoblast $H y$. has arranged itself anew and has been broken up into smalier cells and is completely corered by the epiblast Ep. The Hypoblast is also beginning to show signs of becoming hollow in the center, and a true archenteron has probably been defined, but as yet there is no communication with the outside. It will also be noticed that the hypoblast, as a whole, has been pushed farther up relatively than in Fig. 10, and that it is in close contact with the epiblast at $M$ and $A$. SinSingularly enough, the first evidence of a mouth appears as a depression in the epiblast at a point nearly opposite $S$; the depression $M$ slowly deepens and finally breaks through, and is brought into communication with the archenteric carity when not long after the rent breaks through at $A$, when the larral stomach and intestine are complete. By this time the relum $V$ is dereloped, enabling the embryo to swim about by means of the rapid 


\section{1}

lashing movement of the long lash like filaments arranged in a circle between the shell and the mouth.

In a general way, the segmentation of the egg of the clam appears to resemble, in its early stages, at least, the same process in Anodonta, as described by Flemming. * The conclusion that the clam is exactly parallel to Anodonta in its development is not, however, warranted for this reason, and to clear up the questions raised here, we must await the results of another season's work.

*Studien in der Entwickelungsgeschichte der Najaden. Sitzb. de k. Akad, der Wissensch.,LXXI。 Bd., I and II Hft., p. 8r. Vienna, 1875 . 



\section{APPENDIX B.}

O Y S T E R

AND

FISH LAWS. 



\section{OYSTERS.}

PUBLIC GENERAL LAW S.

Chapter 198, Laws of 1880, repeals Chapter 181, Laws 1874, (Sections 3 and 5 of which were repealed and re-enacted by Chapter 380, Laws 1876, and enacts the following in lieu thereof, to be Article 71, Code of Public General Laws, title "Oysters."

SEction 2. Be it enacted, That no steamer shall be used or employed in catching oysters in the waters of this State, with scoop, dredge or similar instrument, and no other boat shall be used in catching oysters with scoop, dredge or similar instrument, without first having been licensed as hereinafter provided.

SEc. 3. And be it enacted, That the Comptroller of the Treasury shall, upon application of any person who has been a resident of this State for twelve consecutive months next preceding such application, and to no other person, issue a license to such resident to employ such boat in catching oysters with scoop, dredge or similar instrument, within the waters of Chesapeake Bay and in Eastern Bay, ontside of a line drawn from the southwest corner of Second Kent Point to Wade's Point: provided, that nothing herein contained shall authorize the catching of oysters with scoop, dredge or similar instrument, on any oyster bar within one and a half miles of Tolley's Point. Sandy Point, Hackett's Point, Thomas' Point, Holland Island Bar, 'Three Sisters, Swan Point Bar, Poplax Island, one-quarter of a mile west of, and between the island and the main land, nor within a half mile of Plum Point, and to buy and sell oysters in this State, which license shall hold

Must obtain license.

Who to re ceive license.

Prohibition specified. 
good for one year, but shall only authorize the catching of oysters between the fifteenth day of October and the first day of April, but it shall be lawful for the owner of any such boat licensed, whenever said owner shall sell and convey by bill of sale for a bona fide consideration, said boat, unto any person who has been a resident of the State of Maryland for at least one year, to transfer the said license to said vendee with said boat, which license, when transferred, shall entitle said vendee with said

Right to transfer license. facts.

Make oath of Must be bona fide owner. boat to the same privileges for catching oysters in the waters of this State, that the original vendor or assignor had before said assignment; provided, the said vendee and assignee shall appear before the Comptroller of the Treasury and make oath before him to all the facts, matters, things and prerequisites required of said original vendor or assignor before taking out such licenses, upon which said license the said Comptroller shall certify the fact of said vendee or assignee have taken said oath, and for which said assignee or vendee shall pay the sum of five dollars, to be paid to the State of Maryland.

SEc. 4. And be it enacted, That the owner of such boat shall make oath before the Comptroller or his clerk, or if the owner be a resident of Baltimore city, he shall make oath before the Clerk of the Court of Common Pleas, or if a resident of a county, shall make oath before the Clerk of the Circuit Court of said county, that he is the bona fide owner of such boat to be described in the license; that he has been resident of the State for the time before mentioned; that there is no lien on said boat by a non-resident; that the said boat is not held with an intention to violate the provisions of this law, such applicant shall produce before the Comptroller, at the time of such application, the certificate of the taking of such oath, the Custom-House enrollment or license of such boat; and if such boat is under Custom-House tonnage, the owner shall swear as to her ton- 
nage ; the master of such boat shall make oath before the Comptroller or his clerk; or if a Swear to resident of Baltimore city, before the clerk of the Court of Common Pleas, or the clerk of the county whereof he may reside, that he has been a resident of the State of Maryland for twelve months next preceding the time of taking such oath.

SEc. 5. And be it enacted, That before granting such license, the Comptroller shall receive for it from the applicant, at the rate of three dollars per ton for every ton the boat may measure; the license shall be exhibited whenever be exhibited. called for by any officer of the State of Maryland.

SEc. 6. And be it enacted, That any person who shall violate any of the provisions of the preceding sections shall be deemed guilty of a misdemeanor, and upon indictment and conviction in any Circuit Court, or before any Justice of the Peace of this State, before whom such case is tried, shall be fined not less than fifty dollars nor more than two hundred dollars, or sentenced to the House of Correction for a term not less than three months nor more than three years ; and the boat or vessel used in said violation, together with the paper's, furniture and tackle on board of said boat or vessel at the time of the said violation, shall pay a penalty of not less than fifty dollars nor more than three hundred dollars for each and every violation of the preceding section.

SEc. 7. And be it enacted, That upon information given under oath to any Judge of the Circuit Court or Justice of the Peace, of any violation of any of the provisions of this act, he shall issue his warrant to the sheriff or any Issue warrant. constable, requiring any of them to whom it may be directed, to summon a posse comitatus if necessary, and proceed forthwith to arrest the party or parties alleged to have been en-

Penalty for violation. 
gaged in the riolation of this act, and to seize and to take possession of any boat. canoe or ressel, together with all her tackle and apparel on board of the same, and deliver the same to the Judge of the Circuit Court or a . Justice of the Peace of this State, to be dealt with according to the provisions of this act.

SEc. S. And be it enceted, That any person or persons who shall resist any officer authorized under this act to make arrests. shall be deemed guilty of a misdemeanor, and upon indictment and conviction thereof in any court having jurisdiction, shall be inmprisoned in the House resistance. nor more than three vears. in the discretion of the comrt; the parties tried and acquitted under this act shall have the cost of such trial paid by the Comptroller of the State out of the funds created by this act.

SEc. 9. And be it endeted. That it shall be the duty of the sheriff. constable or officers of Who to ar the State Fishery Force, to arrest any person or rest. persons. and to seize any canoe. boat or vessel found violating any of the provisions of this act, and bring the offender or offenders before a Judge of the Court having criminal jurisdiction. Or a Justice of the Peace most conrenient or accessible. to be dealt with as herein prorided.

Give immediate hearing.

SEc. 10. And be it enacted. That the Judge or Justice of the Peace, before whom ans per. son or persons may be brought. charged under oath with violating any of the provisions of this act. the said Judge or "Justice of the Peace shall either gire the case an inmediate hearing, or at the instance of the party or parties charged with a riolation of this act. shall appoint some early day within the next ten days thereafter, to hear the case. the parts or parties charged giving such good and sufficient bail as said Judge or Justice shall require, for his or their attendance, and on conviction of the offender or 
offenders, the said Judge or .Justice of the Peace shall impose a tine upon the offender or offenders of not less than fifty dollars nor more than two hundred dollars, or imprisonment in the House of Correction for not less than three months, nor more than three years, and the boat or vessel used in such violation, together with all the apparel and tackle on board, at the time of said violation, shall be held until said fine and costs are paid; provided, that if said fine shall not be paid within twenty days thereafter, it shall be the duty of the said Judge or Justice of the Peace to decree forfeiture of the said boat or vessel, together with all the apparel and tackle on board, and he is hereby authorized to order any sheriff or constable to sell said boat or vessel, together with all the apparel and tackle on board, to the highest bidder, for cash, after giving at least twenty days' notice of the time and place of said sale, and the proceeds of said sale shall go to the payment of the fine and costs of such prosecution, and the balance, if any, shall be paid to the owner of said boat or vessel; provided, the said owner shall have the right of an appeal to the Circuit Court.

SEc. 11. And be it encucted, That any boat owned wholly or in part by any non-resident, used in catching oysters in this State with scoop, dredge or similar instrument, shall be condemned by order of any Judge of the Circuit Court nearest the place of her capture, or if captured in Baltimore, by order of the Judge of the City Court, and shall be sold by the sheriff of the county where condemned, or if condemned in Baltimore city, by the sheriff of said city, to the highest bidder, for cash, after twenty days notice of the time and place of sale, such notice to be published at least three times in a newspaper having the largest circulation, printed in Baltimore city or in the county where condemned; one-fourth of the proceeds of such sale shall be paid to the party 
making the capture, (except the officers of the State Fishery Force, and the balance shall be paid into the Treasury of the State to be credited to the Orster Fund.

Sec. 12. And be it enacted, The fines accruing under this act shall be paid by the

Fines to be paid to clerk. sheriff, constakle or officer's of the State Fishery Force. collecting the same, within ten days, to the clerk of the county or city where such fine mar accrue, and such clerk shall account for the same in his next quarterly term to the Comptroller of the Treasury, to be placed to the credit of the Orster Fund.

SEc. 13. And be it encucted, That it shall be mnlawful, without authority from the owner, for any person or persons to take or catch planted or bedded oysters : any person or persons riolating the jrovisions of this section shall be deened guilty of a misdemeanor, and on conviction in the Circuit Court of the county wherein the oysters were bedded, shall be fined

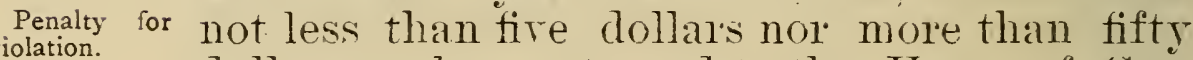
dollars, or be sentenced to the House of Correction for a term not less than three months nor more than three years, at the discretion of the Judge or Justice trying the same.

When unlawful.

SEc. 14. And be it encucted, That it shall be unlawful for any person or persons to take or catch orsters, except for prirate use. to the amount of fire bushels per day, or for sale of the same to any citizen or citizens of the neighborhood, and to them only for the purpose of being consumed where sold, or for the purpose of replanting or bedding in the waters of the counties wherein they are caught, or for sale to the citizens of the county wherein they are caught, and to them only for the purpose of replanting or bedding in the waters of said comnties, between the fifteenth day of April violation. and the first day of September. in each and every year; any person riolating this section 
shall be deemed guilty of a misclemeanor, and fined by a Justice of the Peace of the county wherein the offence was committed, not less than fifty dollars, nor more than two hundred dollars, or imprisonment in the House of Correction for not less than three months nor more than three years.

SEc. 15. And be it enacted, That it shall be unlawful for any person or persons to take or catch oysters on Sunday or at night, or to carry oysters in the shell ontside the State, between the first day of April and the first day of September; and any person or persons violating this section shall be fined a sum of not less than fifty dollars nor more than three hundred dollars, or sentenced to the House of Correction for a period of not less than three months nor more than three years, or forfeit the boat, vessel or canoe used in violation of this Act, at the discretion of the Judge or Justice of the Peace trying the same.

SEc. 16. And be it enacted, That the Comptroller of the Treasury shall have painted in black figures on white canras two sets of numbers, corresponding to the license to catch oysters with scoop, scrape, dredge or any similar instrument, each figure shall be twenty-two inches in length and of proportionate width, and the figures at least six inches apart, and he shall give to each person taking out such license two numbers thereof, one of which shall be firmly sewed upon the starboard side, and in the middle of that part of the mainsail which is above the close reef, and the other number on the port side, and in the middle part of the jib, which is above the bonnet and reef ; these number's shall be placed in an upright position, and worn at all times during the dredging season, and shall not be concealed or defaced, and no other number shall be exposed to view or used than that which is furnished by the Comptroller; any person or persons who shall violate

Numbers to correspond with license.

Numbers where placed. 
the provisions of this section, shall be deemed guilty of a misdemeanor, and upon conviction in any Circuit Court in this State, or before a Justice of the Peace, shall be fined not less than fifty dollars, nor more than one hundred dollars, or imprisoned in the House of Correction, for a period of not less than three months, nor more than two years: provided, the Court or Justice of the Peace trying the same, shall be convinced that the provisions of this section have been intentionally violated.

Must obtain license.

Boundaries to be strictly construed.
Sko. 17. And be it enacted, That any resident of this State, desiring to use any canoe or other boat, in catching or taking oysters with rakes or tongs for sale, in any of the waters of this State, shall first obtain, by application to the Clerk of the Circuit Conrt of the county wherein he may reside, a license therefor, and such licenst shall have effect from the first day of Jnine, in the year in which they may hare been obtained, to thr first day of June next succeeding: provided, that such license shall not authorize the use of said canoe or boat in taking or catching oysters in any creek, cove, river, inlet, bay or sound within the limits of any county, other than that wherein the license shall have been granted, and that the boundaries of counties bordering on navigable waters, shall be strictly construed so as not $t$ " permit the residents of either county to take or catch oysters beyond the middle of the dividing channel; provided, that nothing in this section shall be so construed as to prevent the citizens of St. Mary's and Calvert counties from using the waters of the Patuxent river in common, or the citizens of Queen Amne's and Kent counties from using the waters of Chester river in common, or the citizens of Dorchester and Wicomico counties from using the waters of the Nanticoke river in common, or the citizens of Queen Anne's and Talbot counties from using the waters of Wye river and the mouth thereof in common. or citizens 
of Dorchester or 'Talbot counties from using the waters of the Choptank river in common.

SEc. 18. And be it enacted, That each and every license to take or catch oysters for sale, with rakes or tongs, shall state the name and State name and residence. residence of the person to whom the same is to be granted, the number, together with the length to be obtained by top or over all, measurement of the canoe or boat licensed, the county in which the same is to be used and the period at which said license will expire, and every applicant for such license shall pay to the Clerk of the Court where such license may be granted, and before the issuing and delivery of the same, according to the following rates, viz: For any boat measuring in length twenty feet or less, the sum of two dollars; measuring from twenty to twenty-five feet, the sum of three dollars; measuring from twenty-five to thirty feet, the sum of four dollars ; and all over thirty feet, including sloops under Custom House tonnage, the sum of five dollars each, and all oysters taken with rakes or tongs shall be culled upon the natural beds where they are taken; the amount received from tonging license to be paid by the Clerk to the School Commissioners, for the public schools in the respective counties where such license is issued; provided, the sum received from white tongers shall go to white schools, and the sum from colored tongers shall go to the colored schools.

S.ec. 19. And be it enacted, That every applicant for license to use any canoe or other boat in taking or catching oysters with rakes or tongs, shall be required to make oath or affirmation before the clerk authorized to issue the same, or some Justice of the Peace, on whose certificate of the taking of such oath or affirmation the clerk shall issue said license; that the facts set forth in said license are strictly true; that he has been a bona fide resident of the county for the twelve months next

Make oath or affirmation. 
preceding his application for said license; that he desires and intends to use said canoe or boat only in the county in which he resides, or in the waters used in common, as herein provided in this act; that he will not allow the same to be used for taking oyster's by non-residents of the county; that he will comply with and obey all the laws of this State, regulating the taking or catching of oysters: and every person to

Paint number of boat.
Blank licenses to be furnished clerks. whom such license shall have been granted, shall paint the number of his canoe or boat on the ontside thereof, near the gunwale, in black figures, and not less than three inches in length, and of proportionate width, in a white ground, and no number, other than that in the said license, shall be exposed to view on said canoe or boat; and any person failing to comply with this provision before using said boat or canoe for the purpose aforesaid, shall, on conviction thereof before a Justice of the Peace, be fined not less than five dollars, nor more than ten dollars, and any person who may refuse to pay said fine, shall be committed to the county jail for the period of thirty days, or until said fine be paid.

SEc. 20. And be it enacted, That the Comptroller of the 'Treasury shall cause to be printed and delivered to the. Clerks of the Circuit Courts of the several counties, the requisite number of such blank licenses, and take receipts for the same, as for orther licenses furnished; and the said clerks shall, on the first Monday of March and December, in each year, return to the Comptroller a list and account of such licenses, issued by them, and no licenses to take or catch oysters with rakes or tongs shall be issued to any hoat or vessel which is licensed to take or catch oysters with scoop, drag, dredge or any similar instrument.

Sec. 21. And be it enacted, That if any person shall use any canoe or boat, not licensed as required by the preceding section of this 
article, in taking or catching oysters with rakes or tongs, except for private use, he shall, upon conviction thereof before a Justice of the Peace for the county wherein the offence has been committed, be find not less than twenty nor more than one hundred dollars; and in case of refusal to pay the said fine, said party shall be confined in the House of Correction for a period not less than three months, nor more than three years.

SEc. 22. And be it enacted, 'That all moneys arising from fines, penalties or forfeitures imposed under this article, shall, upon warrant of the Comptroller, be paid into the Treasury and placed to the credit of the Oyster Fund; and the Comptroller is hereby required to state in his annual report, particularly, the receipts and expenditures on account of said fund, the balance standing to the credit of the State at the time of making such report.

SEc. 23. And be it encuted, That the owner or owners of any land bordering on any of the navigable water's of this State, the lines of which extend into and are covered by said waters, shall have the exclusive privilege of

Have exclu. sive privilege. using the same for protecting, sewing, bedding or depositing oysters or other shell fish, within the lines of their own land; and any owner or owners of land lying and bordering upon any of the waters of this State shall have power to locate and appropriate in any of the waters adjoining his, her, or their lands, five acres, for the purpose of protecting, preserving, depositing, bedding or sowing oyster's or other shell fish; and that any other citizen of the State shall have power to locate and appropriate five acres in any waters in said State not located or appropriated; provided, thirty days notice in writing shall be given the owner or owner's, occupant or occupants of land bordering on said water proposed to be located; that the owner or owners, occupant or occupants,

Fines to be paid into treas. ury. cate five acres. 
may have priority of claim, and if they shall fail to locate or appropriate the water mentiontioned in said notice within thirty days after receiving the same, then it shall be open and free to any one under the provisions of this secDescribe by
takes. tion : provided, also, that the said location or appropriation shall be described by stakes, bushes or other proper and risible metes and bounds. which description shall be rednced to writing under the oath of some competent surreror, and recorded at the expense of the party locating or appropriating the same in the office of the Clerk of the Circuit Court in the county wherein such land mar be located; and provided, also. that such location and appropriation shall not injure, obstruct or impede the free navigation of said waters; and provided, that no natural bar or bed of oyster's shall be so located or appropriated, and that six months peaceful possession of all locations of oyster grounds under the laws of this State shall constitute a good and sufficient title thereto: but should any one. within the six months herein provided. be charged with locating or appropriating ans natmal bed or har hereinbefore prohibited, the question may be at once submitted by any person interested, to the judge of the circuit court in the countr where such questions shall arise, who, after haring giren notice to the parties interested, Hear test- proceed to hear the testimiony and decide the
mony. case, and if decision be in faror of the party locating said five acres. said decision shall be recorded with the original record of said fire acres, and shall in all cases be conclusive eridence of title thereto.

SEc. 24. And be it enacted. That if any creek, core or inlet, not exceeding one hundred vards at low water in breadth at its mouth, make into the lands, or that if any creek. core or inlet of greater width than one hundred yards at low water mark. make into the lands, the owner or owners, or other lawful occupant 
or occupants, shall have the exclusive right to to use such creek, cove or inlet when the mouth right. of said creek, cove or inlet is one hundred yards or less in width, and when the said creek, cove or inlet is more than one hundred yards in width at its mouth at low water, the said owner or owners, or other lawful occupant or occupants, shall have exclusive right to use such creek, cove or inlet, so soon as said creek, cove or inlet in making into said land or lands, shall become one hundred yards in width at low water, for preserving, depositing, bedding or sowing oysters or other shell fish, althongh such cove, creek or inlet may not be included in the lines of any patent.

SEc. 25. And be it enacted, That the Board of Public Works is empowered and directed, to purchase for each of the guard boats, such arms and ammunition as may be necessary to make them efficient.

SEc. 26. Be it enacted, That for the more efficient working of the State Fishery Force, the waters of this State shall be divided into seven districts, of which the waters of Kent county and Queen Anne's, shall be the first; the waters of Queen Anne's and Talbot, shall be the second; the waters of Dorchester and Talbot, the third ; the waters of Wicomico, the fourth; the waters of Somerset comnty, the fifth ; the waters of Anne Arundel county, the sixth; the waters of St. Mary's, Charles and Calvert, the seventh; each of the said districts shall be guarded by one sailing vessel, except the third and seventh, which shall be guarded by two; and it shall be the duty of the deputy commander of the first district, to guard the waters of Chester river, belonging to Queen Anne's county and the waters of Kent county, including Swan Point Bar ; and the duty of the commander of the second district, to guard the watrs of Eastern Bay and its tributaries, and the waters of 'Jallbot county, as far down as Black

Divide into districts.

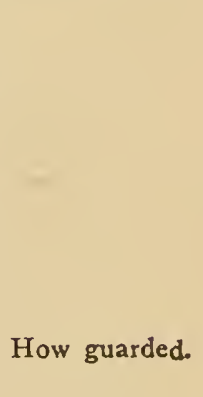


Walnut Point; and it shall be the duty of one of the deputy commanders of the third district, to gnard the waters of Choptank river and its tributaries, which lay in Talbot county: and the duty of the commander of Wicomico county boat, to guard the waters of Wicomico county, and the line between Somerset and Wicomico county; and the remaining commanders to guard their respective districts ; provided, that the Board of Public Works or the commander of the Fishery Force, are hereby authorized and empowered to order the deprity commanders to do duty in any of the waters in this State

Perform duties in other waters.

Power to appoint. when, in the judgment of either, they may deem it necessary.

SEc. 2\%. And be it enacted, That the Board of Public IVorks shall have power to appoint a stitable person to conmand said force, to appoint the deputy commanders for their respective districts from jersons of the counties whose waters comprise the different districts, who shall be commissioned hy the Governor, and the said conmander and deputy commanders shall have power to ajpoint their subordinates, and select their crews: and the term of office of said commander and deputy commanders shall be for two rears. unless sooner removed for incompetency or neglect of duty. and if any of said officers shall fail in the discharge of his duty by reason of collusion with parties interested in violating any of the provisions of this act. he shall be guilty of a misdemeanor, and on indictment and conviction in a comt of law, shall be fined or imprisoned at the discretion of the comrt.

Power to re-

SEc. 28. And be it enacted. That the Board move. of Public Wrorks shall have the power to remove any officer of said force for neglect of duty or incompetencr. and any officer commanding in said force, shall have the power to remore any subordinate under his command, and appoint a person to fill the racancy whenever the inter- 
est of said service may, in his judgment, require him to do so.

SEc. 29. And be it enacted, That the Board of Public Works shall have power to keep the steamer and said vessels in good order, and the Treasnrer of the State, upon requisition of the said Board, and the warrant of the Comptroller, is hereby required and directed to pay the sum or sums necessary to carry out the provisions of this act.

SEc. 30. And be it enacted, That the commanding officer who shall have charge of the steamer, may be selected from the State at large, but the deputy commandels shall be selected from the districts in which they are to serve.

SEc. 31. And be it enacted, That the commanding officer be, and he is hereby, required to keep his vessel constantly on duty when circumstances will permit ; and that every locality. where a violation of the law is likely to occur, shall be visited as often as the duties of the force and condition of the vessel will allow, and that every three months a report shall be made to the Board of Public Works of all official action taken under the law, and of all money received for license issued to parties engaged in carrying oysters taken in this State, which on warrant of the Comptroller shall be paid into the Treasury.

SEc. 32. And be it enacted, That it shall be the duty of the depnty commanders to confine themselves ordinarily to their several districts; but it shall also be their duty to enforce any of the provisions of this act in any waters adjacent to their districts, when a violation of the same shall come to their knowledge, and that they shall report quarterly to the Comptroller the amount of moneys received for licenses issued to persons engaged in carrying oysters, taken in this State, and on receiving his warant shall pay the same into the 'Treasury.

To pay sums necessary-

How selected.

Keep on constant duty.

Confine to districts. 
SEc. 33. And be it enacted, That the commanding officer and the deputy commanders of said force, shall. before entering upon the disTake oath. charge of their duties, take, before one of the Judges of the Circuit Court, the oath prescribed by the Constitution, and the commanding officer

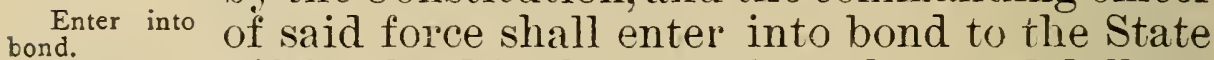
of Maryland in the sum of ten thousand dollars, and each deputy commander in the sum of three thousand dollar's. to beapproved by said judges, for the faithful performance of their duties as prescribed in this act ; the said bond or bonds to be filed with the Comptroller.

Salary or commander.

Salary of appointees.

SEc. 34. And be it enacted, That the salary of the commanding officer in charge of steamer shall be one thousand five hundred dollars per annum, and he shall have power to appoint one officer, at a salary of seren hundred dollars per annum ; one engineer at eight hundred dollars per annum, and one officer at six hundred dollars per annum, tw o seamen at twenty-five dollars per month; two seamen at twenty dollars per month : one fireman at thirty dollars per month; one fireman at twenty dollars per month; one steward at twenty dollars per month, and one cook at twenty-five dollars per month; and each deputy commander shall receive a salary of eight hundred dollars per annum: he shall have power to appoint one officer at a salary of five hundred and fifty dollars per annum, and three seamen at a salary of thirty dollars per month each, to be selected from the districts in which they are to serve.

SEc. 35. And be it enacted, That the officers and crew of the steamer aforesaid. shall each receive one ration per day, of tile quality and quantity, such as is allowed by law to the offiRations. cers and crew of the Revenue Marine of the United States, but no rations shall be allowed to officer's or crews of the sailing vessels.

SEc. 36. And be it enacted, That the officers 
and crews aforesaid, shall be paid monthly by the rreasurer, upon warrant of the Comptroller Monthly payments. and the certificate of the commanding officers, that their duties have been performed, as required by law.

Sko. 37. And be it enacted, That all oys.ers in the shell disposed of in the State of Maryland, shall be measured in a sealed measure of any capacity, from half a bushel to three bushels, that may be agreed upon between the seller and purchaser ; provided, that the said measure or measures shall contain in quantity for each bushel thereof, according to the following dimensions: That is to say, sixteen and a half inches across, from inside to inside at the bottom, eighteen inches across from inside toinside at the top, and twenty-one inches diagonal from the inside chime to the top, and the same shall be even or struck measure.

SEc. 38. And be it enacted, That it shall be the duty of the purchaser or seller to have and use said measure or measures, duly inspected and sealed by the proper officers, and that no other measure stiall be used under a forfeit of fifty dollars for each and every offence, to be recovered before any Justice of the Peace, by action of debt, in the name of the state of Maryland, one-half to go to the informer, the other half to be paid to the Comptroller, to be placed to the credit of the oyster fund.

SEc. 39. And be it enacted, That if any hoat or vessel shall be seen sailing over any of the waters of this State, which are exempted from dredging by law, in the same manner in which they sail to take or catch oysters with scoop, scrape, drag, dredge or similar instrument, the said boat or vessel shall be pursued by any officer or officers anthorized by this act to make arrests, and if said boat or vessel apprehended by said officer, shall be found to have on board any wet oysters on deck and properly equipled

Inspect and seal measure.

Dimensions of measure.

How meașured

(1)


for taking or catching oysters with scop, scrape, drag or dredge or similar instrument, it shall be prima facie eridence that the said boat or ressel has been used in violation of this act,

Officere must arrest. Fine for vioation.

Where culled. and it shall be the duty of the officer to arrest the person in command of said boat or vessel, and seize the said boat or vessel, together with all her equipments, and bring the same before a Judge or Justice of the Peace most accessable, to be dealt with according to law; provided. that nothing in this act shall be construed to prohibit vessels from seeking harbor in any waters of this State.

SEc. 40. And be it enacted, That all oysters taken from any of the waters of this State, shall be culled upon their natural bed or bar; any person or persons violating the provisions of this section, shall be deemed guilty of a misdemeanor. and upon trial and conviction before any Judge or Justice of the Peace of this State. shall be fined not less than fifty nor more than three hundred dollar's, or sentenced to the House of Correction for a term not less than three months, nor more than three years, or forfeit the canoe or vessel used in said violation.

SEc. 41. And be it enacted, That any person Right of apor persons convicted under any of the provisions of this act. shall, in all cases, have the right of an appeal.

How con- SEc. 42. And be it enacted, That nothing in strued. this act shall be construed so as to apply to Worcester county.

SEc. 43. And be it enactert, That it shall be the duty of the commander of the steamer to Arrest for diligently watch and guard and to arrest all persons dredging, tonging or scooping withont license, and the commanders of the sailing ressels shall likewise guard and arrest all persons for any violation of the law in this respect in their several districts; any violation of duty 
in this respect shall be deemed a sufficient cause of removal.

SEc. 44. And be it enacted, That nothing contained in this act shall be construed to effect any prosecutions for the riolation of the existing law now pending in this State.

SEc. 45. And be it enacted, That this act shall take effect from the date of its passage.

Effective. 


\section{PUBLIC LOCAL LAWS.}

\section{DORCHESTER COLNTY.}

Capter 299, Laus 1881), amend.s Chapter 325, Laros 1878, which repealed Chapter 214. Laws of 1874, by adding an additional section.

Secrion 13. And be it encucted. That the capCaptains to tains of erery licensed canoe, boat or ressel under arrest. this act, shall be a police officer for making special arrests, and the school Commissioners of Dorchester countr are herebr authorized to allow any such captain one-half the tine that is paid to the said board for arrests made by him of non-residents taking or catching oysters in the waters of said county.

\section{POTOMAC RITER.}

Chapter 36. Laws 18so, regulates the catching of Oysters in the Waters of the Potomac River.

Section 1. Be it enacted by the General Assembly of Maryland. That no boat or ressel propelled by steam shall be used in catching oysters in the waters of the Potomac Rirer, and no other boat shall be used in catching oysters

Not to catch oysters without license. with scoop, dredge, drag or similar implement, in the waters of said river. without first having been licensed as hereinafter prorided.

SEc. 2. Ard be it enceted. That the Comptroller of the Treasury shall, upon the applica- 
tion of any person who has been a residentcitizen of this State for twelve months next preceding such application, and who is the bona fide owner of the boat or vessel sought to be licensed, and to no other person, issue a license to use such boat or vessel in catching oysters with scoop, dredge, drag or similar implement within such of the waters of the Potomac River as are not prohibited by the provisions of this act, which license shall hold good for one year, but shall only anthorize the catching of oysters between the fifteenth day of October and the first day of A pril ; but it shall be lawful for the licensed owner of any snch boat, whenever such owner shall sell and convey by bill of sale for a bona fide consideration said boat to any person who has been a resident of this State for the twelve consecutive months next preceding such sale, to transfer the said license to said vendee with said boat, which license, when so transferred, shall entitle said vendee with said boat to the same frivileges for catching oysters in the waters of the Potomac River that the vendor had before such sale, provided that said vendee shall appear before the Comptroller of the Treasury and make oath before him to all the facts, matters, things and prerequisites required of said original vendor before taking out such license, npon which said license said Comptroller shall certify the fact of said vendee having taken said oath, and for which the said vendee shall pay the sum of five dollars, to be paid to the State of Maryland.

Sxc. 3. And be it enacted, That the owner of such boat shall make oath before the Comptroller or his clerk that he is the bona fide owner of such boat to be described in the lirense: that he has been a resident-citizen of the State for the time beforementioned; that there is no lien on said boat held by a non-resident, and that said boat shall not be used in violating the provisions of this act: such applicant shall exhibit late the provisto the Comptroller at the time of such applica-

Certify to fact of oath. ions of this act. 
tion the Custom House enrollment or license of such boat, and if such boat is under Custom House tonnage shall swear to her tonnage.

License to be exhibited.

SEc. 4. And be it enacted, That before granting such license the Comptroller shall receive for it from such applicant the sum of three dollars per ton for every ton the boat may measure; said license shall be exhibited whenever called for by any officer of the State Fishery force or any person having a right under the provision of this act to make arrests and seizures for violating any of its provisions.

SEc. 5. And be it enacted, That no person or boat licensed mnder the provisions of this act shall take or catch, or be used in taking or catching oysters with scoop, dredge, drag or similar implement, in any waters of the Potomac River of less than trelve feet in depth, nor in any of the waters of said river between the Maryland shore and straight lines as fol lows: From the most eastern point of the headland known as Posey's Bluff, to a buoy near the southern or south-eastern point or prong of Herron Island Bar, thence to Blackistone's Island Light House, thence to a buoy near the erid of Cobb Point Bar.

SEC. 6. And be it encacted, That if any person or persons having been licensed under this act to catch oysters with scoop, dredge, drag or similar implement, in the maters of the Potomac river, shall violate the provisions of the preceding sections, such person or persons shall be liable to arrest, and the boats, vessels and equipments used shall be seized, and upon proof of such violation before a Justice of the Peace or a Tudge of the Circuit Court for the county nearest the place of such violation, on arrest and seizmre shall be fined not less than fifty dollar's nor more than three hmudred dollars: and said fines and all costs of prosecution shall be a lien on the boats, vessels and equipments, which, 
if said tine and costs of prosecution be not paid within ten days after judgment, or appeal be not taken as hereinafter provided, shall be sold at public sale to the highest bidder for cash, under such order's and notice as the Judge or Justice aforesaid may prescribe ; if said arrest and seizure be made by an officer of the State Fishery Force, said fine shall be paid into the Treasury of the State; but if made by any other person or persons having the right to arrest and seize, one-half of said tine shall be paid to the Clerk of the Circuit Court of the county in which the case has been tried, to be paid by said Clerk to the Comptroller of the State, and the other half shall be equally divided between the parties who made or assisted in making the arrest and seizure.

Sxc. 7. And be it enacted, That any boat, vessels and equipments owned wholly or in part by any non-resident, used in catching oysters in the waters of the Potomac river with scoop, dredge, drag or similar implement, upon seizure and proof shall be condenmed by any Judge of the Circuit Court or Justice of the Peace of the county nearest the place of her capture, and shall be sold by the Sheriff of the county where condemned, to the highest bidder for cash, after ten days' notice of the time and place of sale; one-half of the proceeds of sale, less half the costs of prosecution and sale, shall be paid to the parties who made the capture, except when the capture was made by the State Fishery Force, and the balance shall be paid into the 'Treasury of the State.

Swo. 8. And be it enacted, That the Comptroller of the Treasury shall have rainted in black figures, on white canvas, two sets of numbers colresponding to the license, to catch oysters with scoop, dredge, drag or similar implement; each figure shall be twenty-two inches long and of proportionate width, and the figures shall be at least six inches apart, and he shall give to each person taking out such

Shall be condemned.
To be sold at public sale. 
license two numbers thereof. one of which shall be firmly sewed upon the starboard side and in the middle of that side of the mainsail. which is above the close reef, and the other number on the port side and in the middle part of the jib. which is above the bonnet and reef. These numbers shall be placed in an upright position and be worn at all times during the dredging season. and shall not be concealed or defaced; and no other number shall be exposed to view or be used than that which is furnished by the Comptroller. Any captain or other person in charge who shall vilolate the provisions of this section shall, upon proof of such violation before a judge of the rircuit court or justice of the peace of the connty nearest which such violation occurred, be subject to a tine of not less than tifty dollars nor more than one hundred dollars, and such fine and the costs of prosecution shall be a lien upon such boat or ressel on which were violated the provisions of this section. and mess said fine and costs be paid within ten days or appeal be taken, such boat or ressel shall be sold at public sale to the higest bidder for cash. under such orders and notice as the juage or justice of the peace may prescribe: one-half of the fine to be paid to norties making the arrest and capture unless the arrest and capture be made by the State Fishrry force, and the halance to the treasury of the State.

SEc. 9. And be it encetcd. That any person who has been a resident-citizen for the twelve months next preceding his application of a county bordering on the Potomac Rirer, desiring to use any canoe or other boat in catching

- oysters for sale, with rakes or tongs in any of the waters of the Potomac Rirer, shall first County li- obtain. by application to the clerk of the circuit court for the county wherein he resides, a license therefor. and sich license shall have effect from the first day of June in the vear in which it may liave been issied to the first day 
of June next succeeding; provided that such license shall not authorize the use of said canoe or boat in taking or catching oysters in any creek, cove, inlet, bay or sound within the limits of any county other than that wherein the license shall have been issued.

SEc. 10. And be it enacted, That each and every license to catch oysters, for sale, with tongs or rakes in the waters of the Potomac River, shail state the name and residence of the person to whom the same is granted, the number and length of the canoe or boat by top or over-all measurement, the county in which the same is to be used, and the period at which said license will expire; said license shall also state that the holder thereof is, by virtue of said license, authorized and required to make, or assist in making, arrest of any persons, and seize any boats, ressels and equipments engaged in violating the provisions of this act. For such license the applicant shall pay to the Clerk of the Cirenit Court issuing the same as follows: For a boat or canoe measuring in length twenty f $\in$ et or less the sum of two dollars ; for a boat or canoe twenty to twenty-fire feet in. length the sum of three dollars; for a boat or canoe twenty-five to thirty feet in length the sum of four dollars; for a boat or canoe over thirty feet in length the sum of five dollars; and for sloops under Custom House measurement the sum of six dollars. And all oysters taken shall be culled mpon the natural beds where they are taken. 'The amount received from tonging licenses shall be paid by the Clerk to the School Commissioners for the Public Schools of the respective counties where such licenses are issued, provided the sum received from white tongers shall be applied to the white school fund, and the sum from the rolored tongers to the colored school fund. No license to tongers under the provisions of this act shall anthorize the catching of oysters for sale during the months of April, May, June, July and August. And any person or persons riolating the 
provisions of this section shall be subject to like penalties as are prescribed by the preceding sections of this act.

Required to make oath. than fifty dollars, to be recovered before a Justice of the Peace of the county, and said fine and costs of prosecution shall be a lien upon the boat and equipments of the offending party, which, unless paid within ten days after judgment, shall be sold under orders and notice prescribed by the Justice of the Peace for the payment of such fine and costs, one-half of such fine to be paid to the County School Commissioners, and the other half to the informer. 
SEc. 12. And be it enacted, That every licensed tonger, under the provisions of this act, shall paint the number of his boat or canoe on ber of boat. the outside thereof, near the gunwale, on each side of the bow, in black figures of not less than four inches in length, and of proportionate width, in a white ground, and no number other than that in the license shall be exposed to view on said canoe or boat; and any person failing to comply with this provision, before using said boat or canoe for the purpose aforesaid, shall be subject to a fine of not less than five dollars, and not more than ten dollars, to be recovered and paid over as provided in section eleven of this act.

SEc. 13. And be it enacted, That if any person shall use any boat or canoe not licensed, as provided by this act, in catching oysters with rakes or tongs, for sale, he shall be subject to a fine of not less than ten dollars and not more than fifty dollars, to be a lien on the boat or canoe of the offender, to be recovered and paid over as provided in section eleven of this act-; and if said fine be not paid he shall be imprisoned in the county jail for not less than two nor more than six months.

SEc. 14. And be it enacted, That the Comptroller shall cause to be printed and delivered to the Clerks of the Circuit Conrts of the counties bordering on the Potomac River, the requisite number of such blank licenses as are required by the provisions of this act, and said Clerks shall, on the first Mondays of March and December in each year, 'return to the Comptroller a list and account of such licenses issued by then ; and no license to catch oysters with rakes or tongs shall be issued to any boat or vessel which is licensed to take oysters with scoop, dredge, drag, or any similar implement.

Skc. 15. And be it enacted, 'That it shall be unlawful for any person to catch oysters on Sunday or at night with scoop, dredge, drag or

Fine and lien on boat.

Deliver blank licenses.

Unlawful. 
similar implement, or by tongs: any person violating this section shall be fined a sum of not less than fifty dollars nor more than one Fine for vio- hundred dollars, the fine and cost of proseculation. tion to be a lien on the boat, vessel and equipments used in violating the provisions of this section, and the case shall be tried and disposed of, and the fine and costs collected and paid over as provided in section six of this act.

SEc. 16. And be it enacted, That it shall be the duty of the officers of the State Fishery Arrest for Force, the sheriffs, constables and licensed tongsmen of the counties bordering on the Potomac River, to arrest any person found violating the provisions of this act, and to seize all boats, vessels and equipments engaged or vessels, \&c. used in such violation, and to bring the offenders before a Judge of the Circuit Court or a Justice of the Peace, most conrenient or accessible, to be dealt with as by this act provided, and to hold such boats, vessels and equipments to be disposed of to secure the payment ot such fines and costs of prosecution adjudged as hereinbefore provided by the preceding sections of this act.

SEc. 17. And be it enacted, That upon information given on oath to any Judge or Justice of the Peace of any violation of any of the provisions of this act, he shall issne his warrant for the arrest of the offender and the seimre of

Issue war. rants for arrest. the boat, ressel and equipments, which warrant shall be directed to the sheriff, constable or any licensed tongsman of the county wherein such warrant is issued, or to any officer of the State Fishery Force, and said persons, when arrested, shall be carried before said Judge or Justice of the Peace, and the boat, vessel and equipments shall be held to be dealt with according to the provisions of preceding sections of this act.

SEc. 18. And be it enacted, That if any perResisting officer. son or persons shall resist any officer author- 
ized by this act to make arrests of persons and seizure of boats, vessels and equipments, he or they shall be deemed guilty of a misdemeanor, and upon indictment and conviction in any Court having criminal jurisdiction shall be fined not less than one hundred dollars nor more than five hundred dollars, or imprisoned in the House of Correction for not less than three months nor more than one year, or both fine and imprisonment in the discretion of the Court; and the fine and costs of prosecution shall be a lien on any boat, vessel and equipments that may have been seized when such offender's were arrested, and such boat, ressel and equipment shall be disposed of to secure the payment of such costs and tine as the Judge of the Court may direct, according to the provisions of preceding sections in this act.

SEc. 19. And be it enacted, That for all oysters bought and sold on the Potomac river the following shall be the standard bushel measure, viz.: A solid iron tub, measuring sixteen and one-half inches across the botton from inside to inside, eighteen inches across the top from inside to inside, and twenty-one inches from the inside bottom, diagonally, to the inside top. 'This measure, even full, shall be a bushel ; and any person using a larger measure shall be subject to a fine of ten dollars for each and every offence against the provisions of this section, to be recovered by proceedings before a Justice of the Peace, one-half to be paid to the informer and the other half to the Comptroller of the State.

SEc. 20. And be it enacted, That any person or persons ieeling aggrieved by the judgment of any Justice of the peace in any trial for a violation of any provision of this act, may appeal to the Circuit Court for the county in which such case may have been tried; provided he or they give notice of such appeal within ten days after judgment, and shall within ten days after judgment pay the costs that have

Fine and imprisonment.

$S t$ and a rd bushel measure.

May appeal. 
Appeal bond.

acrrued. and deliver to said Justice of the Peace an appeal bond with two or more sureties, to be approred by said Justice of the Peace. executed to the State of Maryland. in the penalty of double the amount of fine or penalty adjudged by said Justice of the Peace. said bond to be conditioned for the successful prosecution of said appeal.

SEc. 21. And be it encred. That all moner Money-how placed. paid into the Treasury of the State. under the prorsions of this act. shall be placed to the credit of the "Orster Fund."

SEC. 2.2. And be it endated. 'That the proviNot to apply. sions of this act shall not apply to the citizens of the state of Virginia.

SEC. 23. And be it enrected. That this act shall take effect upon the approral of this act. and the pussage of a similar act by the State of Tiroinia.

\section{SOMERSET COLNTY.}

Chapter 40. Lazes 18s0. protects Oysters in certrin maters of Wanotin Rices in Somerset county.

Secrior 1. Be it enared by the General dssembly of Marylond. That it shall not be lawful for an! person or persons to employ ans canoe, boat. or ressel in catching or taking opsters. with scoop. scrape. drag or dredge or ant similar instrument. in the waters of the Manokin River in Somerset countr. east of a straight line from Hazard Point on the south side of said river to South Point on the southeast end of little Deal's Island.

SEc. 2. And be it enacted. That ant person or persons riolating an $\mathrm{r}$ of the provisions of this act shall be fined in a sum not less than one hundred dollars nor more than two hundred dollar's for each and erers offence, and shall stand committed to the county jail until such fine and costs shall be fully paid and satisfied. 
SEc. 3. And be it enacted, That on information under oath of any violation of the provisions of this act to any Justice of the Peace of Somerset county, the said justice shall forthwith issue his warrant to the sheriff or any constable of said county, requiring the officer to whom the said writ shall be directed to summon a posse comitatus, if necessary, and proceed at once to arrest the party or parties alleged to have been engaged in violation of this act, and forthwith bring the offender or offenders before some Justice of the Peace of Somerset county for a hearing, and the said Justice of the Peace shall either give the case an immediate hearing, or at the instance of the party or parties charged with a violation of this act, shall appoint some early day within the next seven days thereafter to hear the case, the party or parties charged giving such good and sufficient bail as said Justice shall require for his or their appearance at the trial, and on the conviction of the offender or offenders the said Justice shall fine such person or persons in a sum not less than one hundred dollars nor more than two hundred dollars and costs, in each and every case, and shall have powrer and authority to commit to the jail of said county such offender or offenders so convicted until such fine or fines, so imposed, and costs, shall be fully paid and satisfied, subject to an appeal in all cases to the Circuit Court for Somerset county, from any judgment or conviction which may be rendered by said Justice of the Peace.

SEc. 4. And be it enacted, That all fines accruing from the enforcement of this act shall be paid by the said Justice of the Peace to the secretary and treasurer of the school board ${ }_{3}^{3}$ of Somerset county, for the use of the public schools of said county.

SEc. 5. And be it enacted, That this act shall take effect on and after the first day of May next.

May commit to jail.

Fines for use of public schools.

Effective. 
Chapter 445, Laws 1880, protects Oysters in the waters of Pocomoke Sound in Somerset County.

SEcTion 1. Be it enacted by the General As-

Unlawful to take oysters.

Fine for violation.

Issue warrant to sheriff

Give immediate hearing. sembly of Maryland, That it shall not be lawful for any person or persons to employ any canoe, boat or vessel in catching or taking oysters with scoop, scrape, drag or dredge, or any similar instrument, within the waters of Pocomoke sound, in Somerset county; nor shall any person or persons take or catch oyster's for sale within said waters otherwise than with tongs, as restricted and regulated by the provisions of the General Oyster Law in force in this State.

SEc. 2. And be it enacted, That any person or persons violating the provisions of this act shall be fined in a sum not less than serentyfive dollars nor more than one hundred and fifty dollars for each and every offence, and shall stand committed to the county jail until such fine and the costs of suit are paid.

SEc. 3. And be it enacted, That on information made under oath of any violation of the provisions of this act to any Justice of the Peace of Somerset county, he shall forthwith issue his warrant to the sheriff or any constable of said county, requiring said officer to proceed forthwith to arrest the party or parties alleged to have been engaged in the violation of this act, and bring him or them before said Justice at once for trial, and upon conviction shall be fined as required by section two of this act.

SEc. 4. And be it enacted, That the said Justice of the Peace shall either give the case an immediate hearing. or at the instance of the party or parties charged, shall appoint some early dav, within the next five days thereafter, to hear the case, the party or parties charged giving such good and sufficient bail as said Justice shall require for his or their appearance ; 
and any party or parties feeling himself or themselves aggrieved by any conviction or judgment of said justice, shall have the right to appeal to the Circuit Court for somerset county, which shall hear and determine the same as other cases on appeal.

SEc. 5. And be it enacted, That this act shall take effect upon the consent and ratification of the provisions of this act by the Legislature of the State of Virginia, as required by the compact between the States of Virginia and Maryland, in the year seventeen hundred and eightyone.

How effective.

\section{WORCESTER COUNTY.}

Chapter 214, Lawos 1880, repeals Sections 2 and 4 of Chapter 277, Laws of 1876 , relating to Oysters in the waters comprised within the limits of Worcester county, and enacts following substitute therefor:

SEcrion 2. And be it enacted, That the clerk of the Circuit Court Ior IT orcester county may issue to any citizen of said county a license to take or catch oysters with rakes or tongs, from the waters of synepuxent bay and its tributaries, until the first day of May next after the issuing of said license ; provided the applicant for said license shall satisfy said clerk by his own oath or other sufficient proof that he is a citizen of said county, and shall pay to said clerk the sum of one dollar, to be paid by said clerk to the County Commissioners of Worcester county, to be expended in the procuring of seed oyster's to be planted in said bay as the commissioners aforesaid may direct; but no person licensed as above, nor any other person, shall take or remove any oysters from the waters of said bay or its tributaries on any Sunday or in the night at any season, nor during the day from the first day of May to the first day of September, or any shells from the natural rocks at any time; provided that nothing herein shall be construed to forbid any person

May issue license.

Satisfy by oath or proof. 
from taking or catching his or her own planted oyster's at any time and with any kind of instrument, and any person violating any of the provisions of this section shall be guilty of a misdemeanor, and upon indictment and conviction therefor, shall be fined not less than ten nor more than fifty dollars for each offence, with costs.

Plant and lay down oysters.

Marked by stakes, \&c.
Fine for violation.
SEc. 4 And be it enacted, That it shall be lawful for any citizen of Worcester county to stake off, not exceeding five acres in any one place in the waters of Synepuxent bay and its tributaries, except upon the natural rocks of said bay and its tributaries, and to plant and lay down oysters in said waters so staked off ; and that no person except the ower of said planted or laid down oysters, or his employee, shall work upon or among said oysters, or in the waters so staked off: provided that, that portion of the said waters in which oysters are, or are intended to be planted or laid down not exceeding five acres in any one place, be kept plainly marked by means of bushes, stakes or buoys ; and any person wilfully or maliciously removing said bushes, stakes or buoys, shall be liable to all the penalties of this section: and provided further, that nothing in this section shall affect the rights of owners of land to the exclusive use of any creek, cove or inlet within their said lands, not exceeding one hundred yards in width at its mouth; and any person violating the provisions of this section, or any of them, shall be liable to be sued as for damages to any other property, and also to indictment by the grand jury of said county, and upon conviction for any such violation shall be finéd not less than ten dollars nor more than one hundred dollars, with costs, or imprisoned not less than one month nor more than six months in the county jail, or both, at the discretion of the court, for each offence; and in any prosecution for violating any of the provisions of this section it shall not be necessary in order to convict, to prove that the offender was 
actually taking up oysters, but only that he was at work in the waters so staked off by bushes, stakes or buoys as aforesaid.

SEc. 3 And be it enacted, That this act shall take effect from the date of its passage.

Effective.

\section{WICOMICO COUNTY.}

Chapter 447, Laws 1880, repeals Chapter 241, Laws 1872, protecting Oysters in the waters of Wicomico County and re-enacts the same with additional sections.

Section 1. Be it enacted by the General Assembly of Maryland, That it shall not be lawful for any person or persons to employ any canoe, boat or other vessel in catching or taking oysters with scoop, scrape, drag or dredge, or any similar instrument, within the waters of Wicomico county; nor shall any person or persons take or catch oysters within the waters of said county, otherwise than with tongs, as restricted and regulated by the provisions of the general oyster law in force in this State.

SEc. 2. And be it enacted, That for the protection of young oysters in the waters of Wicomico county, it shall not be lawful for any person or persons to take or catch oysters above a straight line drawn from Sandy Island on the west side of the Nanticoke river, to Roaring Point on the east side of said river, between the first day of May and the first day of October, nor shall it be lawful for any person or persons, to convey beyond the limits of said county, any oysters from the first day of May to the first day of September in each and every year.

SEo. 3. And be it enacted, That any person or persons violating the provisions of either the first or second sections of this act shall be fined in a sum not less than twenty-five dollars nor more than two hundred dollars, or forfeit the canoe, boat or vessel in his or their possession, violation 
together with the tackle and apparel. and all things on board at the time the offence may hare been committed. and shall stand committed to jail until such fine shall be fully paid and satistied.

SEc. 4. And be it encreted. That on information. under oath, of any riolation of the provisions of this act, to any Justice of the Peace of Wicomico county, he shall forthwith issue his warrant to the sheriff, or any constable, or military officer, requiring either of them to whom it may be directed to summon a posse comitatus. if necessary, and proceed forthwith to arrest the party or parties alleged to have been engaged in the riolation of this act, and to seize and take possession of any canoe or canoes, boat or boats. ressel or ressels, together with all their tackle and apparel. and all things on board of the same belonging to said party or parties, or in their mosession at the time of the offence or offen es and nsed loy him or them in violating this act.

SEc. 5. And be it enacted, That the sheriff, constable or military officer who shall make the arrest, shall forthwith bring the offender or offenders before some Justice of the Peace of Wicomico comnty. for a hearing, and the said Justice of the Peace shall either give the case an immediate hearing, or, at the instance of the party or parties charged with the riolation of this act, shall appoint some early dar, within the next five days thereafter, to hear the case, the party or parties charged with the violation or violations giving such good and sufficient bail as said Justice shall require for his or their attendance, and on conviction of the offender or offenders the said Justice shall fine such person or per'sons in a sum of not less than twenty-five dollars nor more than two hnndred dollars in each and every offence, or shall decree a forfeiture of the canoe or canoes, boat or boats, vessel or vessels, together with all their tackle and apparel, and property found on board at 
the time of the seizure, and shall have power and authority to commit to the jail of said county such offender or offenders so convicted, until such fine or fines so imposed shall be fully paid and satisfied.

SEc. 6. And be it enacted, That the Justice of the Peace before whom any such offender or offenders shall be tried and convicted, shall impose a fine of not less than twenty-five dollars nor more than two hundred dollars, or shall decree a forfeiture of the canoe or canoes, boat or boats, vessel or vessels used in such violation, together with all the apparel, tackle and property found on board, and he is hereby authorized to order any constable, sheriff or military officer, to sell the property so seized, on five days' notice, to the highest bidder for cash, subject to an appeal in all cases to the Circuit Court of Wicomico county ; and after the payment of the expenses attending the arrest and prosecution in any such case, the officer making the arrest shall retain one-fourth of the balance himself, distribute one-fourth among the parties assisting in making the arrest and seizure, and pay over the remaining half to the State treasury, to be placed to the credit of the school fund for said county; provided if such seizure is made by the officers or crew of the Fishery Force of the State, then such portion as would accrue to them under the provisions of this act shall be paid into the treasury of the State and placed to the credit of the school fund for said county.

SEc. 7. And be it enacted, That any person or persons on board of any canoe or canoes, boat or boats, vessel or vessels, engaged in violating any of the provisions of this act, and shall flee to avoid an arrest, the officer endeavoring to make such arrest shall seize such canoe or canoes, boat or boats, vessel or vessels used in such violation, and all property found on board, and the same proceeding thereupon shall be

Power to commit.

Impose fine. peal.
Seize canoe or boat. 
had as in all cases of seizure under other sections of this act.

SEc. 8. And be it enacted, That upon information given, under oath, of any violation of this act, the commander and deputy command-

Duty of State Fishery force.

Arrest with or without warrant. ers of the State Fishery Force of this State, it shall be the duty of the said commander or deputy commanders to arrest the offender or offenders, and seize the boat or boats, canoe or canoes, vessel or vessels, together with all their tackle, apparel and property found on board, and deliver them over to the authorities of the said county, to be dealt with according to the provisions of this act; and the said commander and deputy commanders are hereby authorized to follow such alleged offender or offenders, and make snch arrest and seizure in any part of this State, as well as within the limits of said county.

SEc. 9. And be it enacted, That it shall be the duty of the commander and deputy commanders, with or without warrant, to arrest any person or persons, and to seize and to take into custody any canoe or canoes, boat or boats, vessel or vessels, with their apparel, tackle and property found on board of said boat, canoe or vessel, whenever such person or persons, canoe, boat or vessel shall be found violating, or being used in violating any of the provisions of this act, and bring the offender or offenders before a Justice of the Peace, to be dealt with as herein provided; and it shall be the duty of the Justice of the Peace before whom such person or persons shall have been taken by said officer, to take cognizance of the same and docket a case or cases in the name of the State against such person or persons, and the said boat, canoe or vessel ; and the said justice shall proceed to try the same and render judgment as provided by this act.

SEc. 10. Be it enacted, That it shall not be lawful for any person or persons to take or catch oysters within the waters of Wicomico 
county, except citizens of said county ; and any person or persons violating the provisions of Who are al. this section shall be subject to like penalties as are prescribed in the preceding sections of this act.

Skc. 11. Be it enacted, That all owners and masters of canoes, boats or vessels licensed to take or catch oysters in the waters of Wicomico county, being white men, are hereby constituted officers for the purpose of arresting and taking before any Judge of any Circuit Court or Justice of the Peace who shall have jurisdiction therein, any person or persons who may be engaged in violating any of the provisions of this act, and of seizing any canoe, boat or vessel engaged therein; and all such owners and masters are hereby vested with power to summon the posse comitatus to aid in making such arrest and seizure.

SEc. 12. Be it enacted, That if any canoe or canoes, boat or boats, vessel or vessels, shall be used by any person or persons within the limits of Wicomico county, in the same manner or way in which they are used to take oysters with scoop, scrape, drag, dredge, or similar instrument, it shall be the duty of any officer, created by this act, to pursue such canoe or canoes, boat or boats, vessel or vessels, and if the said canne or canoes, boat or boats, vessel or vessels, shall be found to have on board any scrapes, cranks, dredges, or any similar instruments, or any other equipments necessary to take oysters with scoop, scrape, dredge, or similar instrument, it shall be the duty of the said officer to seize the said canoe or canoes, boat or boats, vessel or vessels, and to arrest the person or persons found on board and bring them before some Justice of the Peace in said county, to be dealt with according to the provisions of this act; and the necessary appurte nances being on board of said canoe or canoes, boat or boats, vessel or vessels, to take oysters with scoop, drag, dredge, or similar instrument, cer to pursue. 
shall be sufficient eridence that the said canoe or canoes, boat or boats, vessel or ressels, have been used in riolating the prorisions of this act.

SEc. 13. And be it enacted, That chapter two

Inconsistent acts repealed. hundred and forty-one, passed at the January session of the General Assembly. in the vear eighteen hundred and serenty-two, entitled -An act to protect orster's within the waters of Wicomico countr." and all other acts and parts of acts inconsistent with the provisions of this act be and the same are hereby repealed. and Effective. that this act shall take effect from the date of its passage. 


\title{
FISH AND FISHERIES.
}

\author{
PUBLIC GENERAL LAWS.
}

Chapter 260, Laws 1880, repeals Chapter 276 , Laws 1878, which repeated Chapter 252, Laws 1876, which repealed Chapter 421, Laws 1874, which repealed Section 2, Article 41, Public General Laws, title Fish and Fisheries, and re-enacts the same with substitutes and amendments, so as to read as follows:

Section 1. No person shall from the tenth day of June to the first day of October in each year fish with hauling seine or drag-net of any kind within the Chesapeake Bay, or any of its tributaries lying northward of the following line, viz: Beginning at Still Pond, in Kent County, and drawn westward to Lego's Point, in Harford County.

Swc. 2. And be it enceted, That any person or persons violating any of the provisions of this act, upon conviction thereof before any Justice of the Peace of the county in which said act has been violated, shall pay a fine of fifty dollars, one-half of which shall go to the informer, and any hauling seine or hauling seines, drag-net or drag-nets, and the boat or boats and material used in fishing the same are hereby declared to be forfeited, and the Justice or Justices before whom said conviction and condemnation shall be had, is authorized and directed to have said fishing apparatus sold by the sheriff or constable making said arrest to the highest bidder, and the proceeds, together with half the fine, alter deducting the cost, shall be paid to the County Commissioners of the county in which said offence shall be committed, for the use of the school fond of said county.

Penalty for violation.

Declared forfeited. 
SEc. 3. And be it enacted, That any person or persons, on conviction, failing to pay the fine as prescribed in the preceding section, shall be imprisoned in the counts jail of the county in which said offence shall be committed: provided, howerer. that anv one so offending shall, upon conviction before ans Justice of the Peace of the countr in which säid offence

Right of appeal. fere.

Not to interPenalty for
violation.

shall be committed, have the right of appeal to the Circuit Court of the county in which said offence shall be committed. under the same restrictions gorerning appeals from the decisions of Justices of the Peace.

SEc. 2. And be it enacted. That this act shall take effect from the date of its passage.

Chapter 354. Law.s 1880, repeals Section 10. of Article 41. Code Public Greneral Lans. title Fish and Fisheries, and re-enacts the same, as follows:

SEc. 10. No float or other derice for fishing shall be anchored or located at any place. so as to interfere with any shore fisher'y now used as such, or which may be hereafter established: nor shall any seine be hauled from such floats or other derice orer the ground usually hauled orer br any shore fishery: nor shall any float haul orer the grounds usually hauled orer by another float, which has cleared its haul and been located in the same position two or more fishing seasons. unless the said float shall abandon for one spring the locality preriously occupied: and any person or persons riolating this section shall. for each offence, pay a fine of not less than twenty-five dollars nor more than one hundred dollars; and for every hour such float or other device shall remain anchored or located, after notice shall be giren by the owner or occupant of such shore, float or fishery, requiring him to remore, he shall par an additional fine of not less than ten dollars nor more than twenty-five dollars. 


\section{PUBLIC LOCAL LAWS.}

\section{BALTIMORE COUNTY.}

Chapter 95, Laws 1880, protects fish in Middle River.

Section 1. Be it enacted by the General Assembly of Maryland, That it shall not be lawful for any person or persons to take any fish in Middle River and its tributary streams, or in the waters of the Chesapeake Bay within one mile of the entrance into the said Middle River, bounding on or lying within Baltimore county, by means of any seines or nets whatsoever.

SEc. 2. And be it enceted, That it shall not be lawful for any person or persons to fish in said waters with nets fastened to stakes, commonly known as pound, fyke or trap nets.

SEc. 3. And be it enacted, 'That upon information given upon oath or affirmation to any Justice of the Peace having jurisdiction of any violation of any of the provisions of this act, he shall issue his warrant for the arrest of the offender or offenders, and for the seizure of the seines, nets, boats and other fishing outfit, to be directed to the sheriff or any constable of the county or other officer anthorized to make arrests, or citizens, mpon the receipt of said warrant to arrest any person or persons violating the provisions of this act, and to seize any such seine, net, boat or other fishing outfit, and found being used in violating any of said provisions, and to bring such offender or offender's before a Justice of the Peace most accessible or convenient, and upon conviction thereof the said offender or offenders shall be fined not less than twenty dollar's nor more than two hundred dollars, one-half of such fine to be

Unlawful to catch fish.

Use of nets \&c.,prohibited. for violation. 
Violationfine for.

Right of appeal.

Effective.

Who are allowed to haul seine. paid to the use of the informer, and the other half to the use of the public schools of the county in which said offence was committed, and shall forfeit the seine, net, boat and other outfit used in such fishing. which shall be sold and the proceeds divided in such mamner, and in case of non-payment of the fine and costs imposed by said .Justice, the said offender or offenders shall be confined in the county jail for a period not exceeding forty days and not less than twenty days, or mutil said fine and costs are paid.

SEc. 4. And be it enceted, That any person or persons who may feel himself or themselves aggrieved by any judgment rendered by a Justice of the Peace under the prorisions of this act, shall have the right to appeal to the Circuit Court of Baltimore county, upon condition and subject to the regulations now provided by the general law regulating appeals from Justices of the Peace, but execution of the judgment of the Instice of the Peace shall not be stayed, unless the party appealing shall give bond to the State in dorible the amount of fine imposed, with security approved by the .Justice rendering the judgment, with conditions to prosecnte his appeal with effect or to pay the tine imposed with all costs.

SEc. 5. And be it enracted. That this act shall take effect from the date of its passage.

\section{CALTERT COUNTT.}

('hapter 179, Laws 1880, motects fish in the waters of Batile, Irunting and St. Leonardis Creeks, ralvert Counity.

Section 1. Be it enacted by the General Assembly of Maryland. That none but citizens of Calvert county shall, for any purpose whatsoever, haul a seine or seines, or any other instrument, in the waters of Battle creek, Hunting creek or St. Leonard's creek, in said county. 
SEc. 2. And be it enacted, That no person whatsoever shall haul a seine or seines, or any other instrument, in said waters of Battle creek, or use Hunting creek or St. Leonard's creek for the purpose of catching fish for sale, or for any other purpose than for home consumption.

SEc. 3. And be it enacted, That any person or persons violating either of the above sections of this act shall be deemed guilty of a misdemeanor, and upon conviction before a Justice of the Peace shall be fined not less than ten nor more than fifty dollars, one-half to be paid to the informer and the other half to the County Commissioners of Calvert county, for county purposes; and that either the State or the defendant shall have the same right of appeal from the judgments of said Justices as is now allowed in civil cases.

SEc. 4. And be it enacted, That the boat and seine used by any person or persons violating either of the above sections of this act shall be responsible for the aforesaid fine.

SEc. 5. And be it enacted. 'That this act shall take effect from the date of its passage.

\section{CARROLL COUNTY}

Chapter 425, Laws 1880, protects,fish in wouters of Carroll and Frederick counties.

Skcrion 1. Be it enacted by the General As sembly of Maryland, That it shall be unlawful for any person or persons to take, catch or destroy any fish in the waters of Flederick or Carroll counties except with hook and line, or by use of the $\mathrm{Cl}_{i}$, net; provided that the Potomac river shall be extmpted from the provisions of this act.

Swc. 2. And be it enacted, That any one violating the provisions of the preceding section shall, uron conviction before a Iustice of the Peace of said counties, be liable to a fine of

Effective.

Catching for sale prohibited.

Penalty for violation.

Who is re sponsible. ful. 
Fine for vio- not less than five dollars nor mole than ten dollars, for each offence, and upon failing to pay such fine and cost of prosecution shall be sentenced to imprisonment in the county jail of the county in which the offence has been committed for a period not exceeding ten days, said fine to be paid to the county Commissioners for the use of the county; provided. however, that any person so convicted shall have the right of appeal to the next term of the county court.

\section{CECIL COUNTT.}

Chapter 27, Laws 1880, repeals Crapter 449, Laws 1878, and enacts the following in lieu thereof :

1. It shall not be lawful for any person to

Not lawful to lash or beat the waters.

Consent to be obtained.

Fines - how recovered. lash or beat the waters of the Elk and Bohemia rivers with rods, poles or sticks. or any other instrument, or to make noises on the decks of any boat or any part of said boat for the purpose of driving fish into any net or seine within a half mile of Plum, Locust. Henderson's, Bich Neck. 'Telsh, Lorts or Oldfield's points on Heron island on the Elk river, or 'Town. Rich, Parlor, Long. Hackett's or George's point on the Bohemia rirer, when said points and island are occupied by persons engaged in gunning for wild forl with decors in the water nor within a half mile of the bridge orer the Bohemia river when occmpied by persons gunning for wild fowl from said bridge, nnless the consent of such persons is first obtained to such fishing as aforesaid. Nor shall it be lawful to fish as aforesaid on the waters of the Elk and Bohemia rivers from the first day of April to the first day of September of each year.

2. Any person violating ány of the provisions of this act shall, upon arrest and conviction thereof before a Justice of the Peace in and for Cecil county, be fined not less than ten nor more than twenty-five dollars, to be recovered as other small debts are recovered. And all 
fines imposed under this act shall be divided as follows: one-half to the officer making the arrest, and the other half to the County Commissioners of Cecil county, to be applied by them to the use and benefit of said county.

SEc. 2. And be it enacted, That this act shall take effect from the date of its passage.

Chapter 197, Laws 1880, repeals Section 1, Chapter 134, Laws 1876, and re-enact the same with amendments.

1. On and after the passage of this act it shall be lawful for any owner, or owners, of land bordering upon the waters of the Elk, Sassafras and Bohemia rivers, and their tributaries, lying and being within the limits of Cecil county, or to whomsoerer they may extend the privilege, to take or catch fish from nets or traps known as pound nets, except from the first day of June to the fifteenth day of September of each year; provided that such pound nets shall not extend to or across any channel, nor shall they be so placed as to, in anywise, olistruct the passage of any vessel or boat engaged in trading in said waters; nor shall any seine or net be used in that portion of said ponnd nets that contines the fish, the meshes of which are less than one and a quarter inches square; nor shall any stake or post be used in placing said pound nets of a greater diameter than four inches in the largest part; nor shall such stake or post be permitted to remain in said waters for a longer perjod than that prescribed in this act for the placing of said pound nets.

SEc. 2. And be it enacted, That this act shall take effect from its passage.

\section{CHESTER RIVER.}

Clapter 114, Laws 1880, regulates catching fish in. (')ester River and its' tributaries in Kent and Queen Anne Counties.

Effective.

Fines - how disposed of.

When lawful Size of meshes.

Effective. 
Siction 1. Be it enacted by the General Assembly of Maryland, That it shall not be lawful for any person or persons to take, capture or destroy fish in the waters of Chester River ol its tributaries in Kent and Queen Anne counties, by seines, drag-nets, set-nets, fish-baskets, fish-pots, weirs, pound-nets, fykes or any other

Unlawful to capture fish.

Unlawful to leave stakes in water.

Not to empty seines on the shore. known or used in the capturing. or destroying known or used in the capturing or destroying fish, or which may hereafter be invented for that purpose, from the tenth day of May to the first day of September, except with hook and line; provided, howerer, that seines or nets may be used for the taking of taylors and mackerel fish, provided the meshes of such nets or seines are in the bar not less than one and seven-eighth inches, or in the mesh less than three and three-quarter inches.

SEc. 2. And be it enacted. That it shall not be lawful for any person or persons who use stakes or poles in setting nets of whatever class or description, in the waters mentioned in the first section of this act, to leave such stakes or poles in the waters where they were nsed, but shall remore, or have removed, such stakes or poles from the waters where they were used, on or before the twentieth day of May in each year, nor shall they again be put down in said waters prior to the twentieth day of September following.

SEc. 3. And be it enceted, That for any person or yersons, in said waters, in the first section of this act, to empty their seines upon the beach or shore at any time whilst engaged in fishing, so as to leave the smaller fish to perish, but to empty the same in water of sufficient depth to enable the smaller fish to return to the waters for growth and maturation, and any person or persons using seines, pound-nets, fish-baskets, fykes, traps or nets of any class or description that catch the fish alive, shall immediately cull them and return the small fish to the waters at the place where they were taken. 
SEc. 4. And be it enacted, That no person or persons, other than the bona fide residents of Kent and Queen Anne counties, shall use any boat or trap of any kind or description used in catching fish in the said waters of Chester River and its tributaries in said counties ; provided, however, that persons owning or occupying lands in said comnties on said river and its tributaries, shall have the right to rent or otherwise grant to non-residents the privilege of fishing in or opposite their shores during the fishing season hereinbefore limited and fixed; and further provided, that the right to take fish with hook and line shall be allowed to all persons at all times.

SEc. 5. And be it enacted, That upon the information of any citizen of either of said counties, that he knows or verily believes that any person or persons have violated any of the provisions of this act, before any Justice of the Peace of either of said counties, the said Justice of the Peace shall docket a case in the name of the State of Maryland against such person or peisons so charged by oath as offending, and issue a warrant at once to some one of the constables or the sheriff of such county, for the arrest of the party or parties charged in said oath with such violation of this act, to be bronght before such .Justice for trial, and said constable or sheriff shall seize the boat, tackle, nets and other equipments owned by or in the possession of such person or persons so charged with the violation of this act, when such violation occurred, or at the time of such arrest, and safely keep such property so taken during the time pending the trial for such offence so charged, and if upon such trial the Justice of the Peace shall enter judgment for the State, such person or persons as against whom such judgment shall be rendered shall be fined not less than twenty nor more than fifty dollars for each and every offence, in the discretion of said Justice of the Peace; one-half of which fine shall be paid to the informer, the other

Not to use boat or trap.

Docket case.

Se i z e boat, tackle, \&c.

Fine for violation. 
half to the school fund of the county where such judgment is rendered, and if such fine is not paid within tive days from the date of said judgment, the said Justice of the Peace shall, on the sixth day thereafter, enter judgment of Enter judgcondemnation against the boat, tackle. nets. or other equipments of such offender which had been seized by the officer aforesaid, which said boat. tackle. nets or other equipments shall, after ten days notice. he, by the said officer: sold to the highest bidder for cash, and from the proceeds of such sale shall deduct the fees allowed constables upon executions, the costs incident to such trial and judgment, together with such expense as such officer may have incurred in the taking and keeping of such property. and shall then divide the residue between How disposthe informel and the schools of the county equally. said officer not to be liable for any damage or loss of said property while in his custody which may oceur without fault on his part.

SEc. 6. And be it enacted. That if any person or pel'sons convicted of offending against any of the provisions of this act shall think himself aggriered by such conriction, he or they may appeal from the judgment of the Justice of the Peace before whom snch conviction is had, at ant time within ten days from the rendition thereof, to the Circuit Court of the county in which the trial was had. If any resistance be made to the officer directed to execute this act by any person or persons offending against the same. the said officer shall summon the posse comitatus and proceed therewith without delay to execute his duty under such warrant. The Justice before whom such offender or offenders shall be taken shall have full power to issue summons for all witnesses that be named to him, to compel their appearance and examine them under oath.

SEc. $\%$. And be it enacted, That all acts or parts of acts inconsistent with this act be and 
the same are hereby repealed, and that this act Inconsistent shall take effect from the date of its passage.

\section{FREDERICK COUNTY. \\ See Carroll County. \\ HARFORD COUNTY.}

Chapter 194, Laws 1880, repeals Section 1, Chapter 41, Laws 1867, and re-enact asfollows :

SEc. 2. And be it enacted, That it shall not be lawful for any person to whip or beat the waters of Romney creek, in Harford county, with poles, sticks, or any other thing for the whip or beat purpose of driving fish into seines, fish baskets, or any other contrivance for catching fish; nor shall it be lawful for any person, at any time, to do said acts, or any other thing for the purpose, or which will have the effect of frightening or driving wild ducks or other wild waterfowl from their feeding or roosting grounds in said creek; nor shall it be lawful for any person, at any time, between the first day of October and the fifteenth day of March, in each and every year, to erect any fish pot, or to fish with any drag net, fish basket, or any other snare, for fish, in the waters of said creek.

KENT COUNTY.

See Chester River.

\section{PATAPSCO RIVER.}

Chapter 76, Laws 1880, repeals Section 1, Chapter 79, Laws 1874, and re-enacts the same with amendment, as follows :

Secrion 1. Be it enacted by the General Assembly of Maryland, 'That from and after the passage of this act it shall not be lawful for any person or persons to take, capture or destroy fish by seine or seines, drag-net or drag-nets, set-net or set-nets, dip-net or dip-nets, stir-net or stir-nets, fish baskets or fish pots, eels weirs, seines, \&c. 
brush or fascine nets, or any means or contrivances whatever of the nature of a seine, which are known to destroy or capture fish, or to destroy or capture them by shooting or striking through the ice, or otherwise, than by hook and line, commonly known as angling, in the Patapsco river, above the point where the old turnpike road from Baltimore to Washington crosses the said river.

Effective.

SEc. 2. And be it enacted, 'That this act shall take effect from the date of its passage.

\section{QUEEN ANNE COUNTY. See Chester River.}

\section{SOMERSET COUNTY.}

Chapter 379, Law 1880, prevents catching fish except in certain cases in Coulbourn's Creek.

Seorion 1. Be it nacted by the General Assembly of Maryland, That it shall be unlaw-

Unlawiul. ful for any person to take or catch, or destroy, in any manner whatever, fish in the waters of Coulburn's creek, in Somerset county, with any kind of seine, net or weir, except such nets as are used for catching rock fish, during the months of March, April and May, which said last mentioned net shall not exceed in length twenty fathoms; but nothing herein shall be construed to prevent fishing with hook and line.

Síc. 2. And be it enacted, That any person or persons who may violate the provisions of this act shall, upon conviction thereof before

Fine for violation. any Justice of the Peace for said county, be fined for each and every offence the sum of twenty dollars, and to stand committed in the county jail until the fine and costs are paid.

SEc. 3. And be it enacted, 'That any person Right of ap
peal. feeling aggrieved by any decision under the provisions of this act shall have the right to appeal to the Circuit Court for said county. 
SEc. 4. And be it encucted, That this act shall take effect from the date of its passage.

Effective.

\section{WASHINGTON COUNTY.}

Chapter 322, Laws 1880, repeals Sections 102 and 103, Code Public Local Laws, title Washington County, sub-title Fish, and re-enacts as, follows:

102. It shall not be lawful for any person to whip or beat the water in the Antietam creek or its tributary streams, Beaver creek, Long Meadow branch and Little Antietam, with poles, sticks or other things, for the purpose of driving the fish into nets, seines, fish baskets or other snares, or to erect any fish pot, or to fish with any net, basket, gig, trot line, or in any other manner, except with the angling rod and dip-nets.

103. Any person offending against the provisions of the last preceding section shall be arrested and taken before a Justice of the Peace, and on conviction, shall forfeit and pay for each offence, and for each month a fish pot may be suffered to remain in any of the streams aforesaid, a fine, not exceeding the sum of twenty dollars, and in default of payment of such fine shall be committed to the county jail for a term not exceding sixty days, the said fine to be recovered in the name of the County Commissioners of Washington connty, before a Justice of the Peace, one-half to be paid to the informer and the other half to the school fund of said county ; provided that any person feeling himself aggrieved by the judgment rendered by any Justice of the Peace, in proceedings under the provision of this and the last preceding section, shall have the right to apneal from said judgment to the Circuit Conrt for Washington county.

Sec. 2. And be it enacted, That this act shall take eflect from the date of its passage.

Fine for violation.
Unlawful acts. 


\section{WICONICO COUNTY.}

Chapter 448 , Lawos 1850 , protects fish in waters of Wicomico County.

SEctiox 1. Be it enacted by the General As-

Unlawful to use pound net, $\& c$.

Not to catch capture, \&c.

Fine for violation.

Sell forfeited property. sembly of Maryland. That it shall be unlawful for an $y$ person or persons to set. stake. or in any manner place any pound net or fyke net made of twine, in the waters of IVicomico county, at any time.

SEc. 2. And be it enacted, That it shall be unlawful for any person or persons to catch. take, capture, kill or injure any shad, herring, rock. perch or any other kind of fish with haul seine. float seine, stake seine. or any other kind of seine. net or fish trap in the waters of said county, between the twentieth day of May in each and every year, and the first day of September in the next succeeding rear.

SEc. 3. And be it erructed. That each and ever'y person who may riolate any of the provisions of this act shall be deemed guilty of a misdemeanor. and upon conviction thereof, before any .Justice of the Peace of Tricomico countr. shall be fined br the said Justice of the Peace sitting in the case a sum not less than ten dollars nor more than twenty-fire dollars, for each and erer riolation aforesaid: and each and erer'r person so conricted and fined shall be committed by the said Justice of the Peace to be confined in the countr jail in said county until the said fine and all costs of the prosecution are paid; and shall. in addition to the said penalties. also forfeit and lose all seines, nets and boats of erert kind which may be used by them in riolating as aforesaid.

SEc. 4. And be it enacted. That it shall be the duty of the Justice of the Peace to decree the forfeiture mentioned in the preceding section, and to order and direct the comstable or other officer making the arrest, to take and sell any property so forfeited as aforesaid, after 
first giving at least ten days' notice by advertisement inserted in some newspaper published in said county, or by advertisement posted in three of the most public places in the neighborhood in which the offender may live, of the time and place of sale, and the said sale shall be for cash; and after deducting all costs and charges of advertising and making said sale, the balance of the proceeds of said sale shall be equally divided, and one-half thereof shall be paid by the officer collecting the same to the informer, and the other half shall be paid by said officer to the treasurer of the school board, for the use and benefit of the public schools in said county.

SEc. 5. And be it enacted, That any person or persons feeling aggrieved by the decision of the Justice of the Peace made and given under the provisions of this act, shall have the right to appeal to the Circuit Court for said county, and shall be notified of the said right of appeal, by the said Justice of the Peace, at the conclusion of the proceedings before him; provided, however, that no appeal shall be granted as aforesaid, unless the person so appealing shall first, within ten days after the entering of the judgment of the said Justice of the Peace, give a full and sufficient bond, with two good and responsible sureties, to be approved by the said Justice of the Peace to the State of Maryland, with condition to prosecute said appeal to the said Circuit Conrt at its next session thereafter, and also to pay the fine already imposed, together with all the costs, both before the . Justice of the Peace and the Circuit Court, in the event the said judgment shall be affirmed.

SEc. 6. And be it enacted, That on information being given on oath to a Justice of the Peace of said county that a violation of any of the provisions of this act has heen, or is being committed by any person or persons, the said Issue warrant for arrest. Justice of the Peace shall forthwith is sue his 
warrant, in the name of the state of Maryland, for the arrest of the offender (r) offenders, which warrant shall be directed to the sheriff or some constable or baliff in said county, and the officer receiving said warrant may summon the posse comitatus, when necessary, to aid him in making any arrest under this act.

How construed.

Effective.

Unlawful to set seines, \&c.

Unlawful to haul with seine.
SEc. 7. And be it enacted, That nothing in this act shall be so construed as to prevent any of the citizens of Wicomico county from catching or trapping fish in any of the waters of said county, for private use, at any time of the year.

SEc. 8. And be it enacted, That all acts and parts of acts inconsistent with the provisions of this act be and the same are hereby repealed, and that this act shall take effect from the date of its passage.

WORCESTER COUNTY.

Chapter 223, Laws 1880, regulates fishing in Synepuxent Bay.

Stction 1. Be it enacted by the General Assembly of Maryland, That it shall be unlawful for any person or persons to place any set seine or seines, or any seines or nets in any manner rendered stationary, in that part of the waters of Synepuxent bay, north of South Point, Isle of Wight bay, Assawoman bay and Saint Martin's river, which is located equally at all points on either side of a line drawn throngh the centre of each of said waters, from the northern to the southern extremity thereof, and extending in width at all points of said line one-third part of the distance which separates the opposite shores of the waters aforesaid, at said points; and all seines or nets used in violation of this act shall be forfeited and sold as hereinafter directed.

SEc. 2. And be it enacted, That it shall be unlawful for any person or persons to haul or fish with any haul or set seine or seines, or to 
leave or to permit to remain setting, any set seine or seines in any part of the waters of Synepuxent bay and its tributaries, north of South Point, during the interval from the hour of six o'clock P. M. of Saturday of each week until the hour of six o'clock A. M. of the following Monday.

SEc. 3. And be it enacted, That no person shall catch by means of a seine or seines any perch fish of not less than a fourth of a pound each in the waters described in the preceding section.

SEc. 4. And be it enacted, That any person violating any of the provisions of this act shall be guilty of a misdemeanor, and upon conviction thereof before a Justice of the Peace for Worcester county, or in the Circuit Court of the same county, shall be fined not less than five or more than twenty dollars, and be inprisoned until said fine and all costs in the case are paid; provided said imprisonment shall not exceed thirty days in any event.

Swc. 5. And be it enacted, That upon information given upon oath to any Justice of the Peace of W orcester county of any violation of any of the provisions of this act, the said Justice shall issue his warrant for the arrest of the offender or offenders, and the seizure of the seine or seines used in violation of this act, which warrant shall be directed to the sheriff or any constable of W orcester county, requiring said offender or offenders to be brought before him, and also all seines used in violating this act, whether the owner of the same be known to him or not.

Swo. 6. And be it enacted, That it shall be the duty of any Justice of the Peace of the county aforesaid, before whom it shall be proven satisfactorily that any nets or seines have been used in violation of this act, to cause such nets or seines to be sold at public auction to the sell at auction.

Weight specified.

Fine for violation.

Issue warrant. 


\section{2}

highest bidder for cash, after giving ten days' notice of the time and place of such sale in at least two public places in the vicinity of said sale, and one-half of all fines collected under this act shall go to the informer, and the other half to the school fund of IV orcester county.

\section{TERRAPINS.}

Chapter 462, Laws 1880, repeals Section 2, Chapter 424, Laws 1878, and re-enacts the scime, as follows:

Section 2. Be it enacted. That it shall be unlawful tor any person or persons to take or catch from the waters of this State, any diamond catch or take. back terrapins of a less size than fire inches in length upon the bottom shell, at any time, provided that the provisions of this section shall not apply to Wrorcester and Dorchester counties. 


\section{ALPHABETICAL INDEX.}

A.

Academy of Natural Sciences

Academy of Natural Sciences, Museum of.....

Achirus lineatus........

Acini of the generative organs.... ........

Actinophrys sol.........

Adanson ..............

Additional apparatus required.............

Adductor muscle.....

Alewives.. .........

Algae .............

American Naturalist. .6,

Amolboid forms.........

Ammen, Admiral.... . .

Animal, The .........

Animal Parasites and Messinates............

Annelids .............

Anodonta ............

Archosargus ...........

Arrangement with "B. \& $\mathrm{O}$ " and "Adams" Express Cos...

Artificial impregnation of the egg.............

Artificial propagation, Importance of .........

Artificially producing green color in oys.....

Ascidians. .........34,

Auray........ . ....

$\mathrm{B}$

Bacteria..............

Baird, Prof. S. F., . x, xI

Balfour.......... 65,

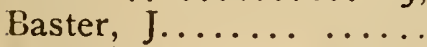

Batrachus tau........32,

Bay mackerel spawning.

Bay of Cadiz, Spain.... .
PAG

Bibliography of literature relating to oyster culture . . . $56-7-8-9$,

LXX

$\mathrm{CXI}$

Big Annemessex ......

Boring mollusk, none in waters of St. Jerome's,

Bouchon, Brandely M. G.

Brach, J.

Branchincardiac vessels

Brooks, W. K., (CVI) 4, 6, I6, 53, 65, 67, 69, 75,

Brown. Klass. u. Ord. des.

Theirreichs III, p. 364 , ditto ditto 384 ,

Bryozoa.. .......... $\mathbf{I}$,

Cadiz, Spain ...........

California Brook TroutSalmo iridea.........

California Salmon--Onchorhynchus quinnat..

Caligus ... .........

Callinectus hastatus....

Campylodiscus ........

Cape May.............

Carp, The............

Carp, disposition of ist lot

Carp distribution in early

Carp, number for distribution ..............

Carp ponds, construction of ..............

Carp ponds in tidal re-

Carp, Ponds necessary for

63

Biocoenosis......... 40

Black-belly herring ..... x x

Blenny. ........... 33

Bojanus $\ldots \ldots \ldots \ldots \ldots$. 13 I880, limited......... LxxxIII

Carp in brackish water... XCIII

Carp letter, Circular ... LX LX gions ........... xcviII

$\operatorname{LXX}$

$\mathrm{XCIV}$

XCIII 
CPAGE.

Carp, species of distributed LXVII

Carp success, Extracts on LxxxilI

Akers, $\mathrm{Col} \ldots . . \ldots \ldots$ LxxxvIr

Baker, H. C........ , x.

Barbour, Jos ....... ธxxxy

Bartlett, S. P........ IXXXYII

Bidwell, Dan'l ....... xc

Blackford, E. G......

Butler, A. P., Cony. Ag. $\quad$ Lxxxv

Callender, Dr........ ixxxvir

Dallam, Jno. S...... LXX L L

Field, Jas. G. ...... xcI

Fletcher, C......... Ixxxvin

Forest \& Strearh IXXXXYI L.MXXIII

Long, J. W......... X XCII

Lorillard, P......... $\quad \mathrm{AxXXIX}$

Metcalf, Volney.... . . LXXXxIy

O'Keefe, A.......... LxxxVIII

Rixford, Geo: C.,ExxxIy LxxxVI

Trump, C ......... Lxxxvi

Wallace \& McGowan Lxxxvir

White, C. S........ Lxxxv

Witowsky, E....... LruxuviI

Cat's tongues.

Cause of swelling of edges of mantle............

Chesapeake Bay (IV) (xt) ( CXII) $3,21,29$

Chesapeake Bay oyster.

Chesapeake form, description of the..........

Chilicthys .............

Chilomycterus .........

Choncologists. ... . . . .

Cilia, . . 10, $12,16,20,22,25$,

Claire .............

Clark, H. Jas. . 6, I1, Iz

Clepsine..............

Clionoe............ 37,

Cloaca. . . .........7,

Cod hatching, Gloucester Harbor.............

Collecting apparatus.... of (CXIII)..........

Collecting, Methods of. .

Collectors, box. .

Collectors, floating . . . 45,

Collectors, shingle......

Collectors, straw-mat....

Collectors, tile.........

Collin, Af. J............

Copepoda .......23, 34

Coscinodiscus. ......... PAGE:

Coste......48, 60, 76 ,

Cothuruia .........22,

Courseulles.... .......

"Covering" cf banks. ...

Crab in the oyster......

Crepidula Glanca........

Creveling, J. P..........

Cymothoids ...........

\section{D}

Dam at Avondale.......

Dam at Iron Works Mills

Dam at jericho

Dam at Laurel

Dam at Relay House

Davaine. . ...5, 16, 65,

DeBroca, P...........

Decaisne, M...........

Depredations of kingfishers .............

Deshayes. .............

Destructive ship worm...

Diagrams showing embankments XCIX,CI, CI I

Diatoms. .............

Difference between eggs of shad and mackerel.

Difference in apparatus for hatching shadand mackerel. ...............

Difference in catch of shad on Potomac and Susquehanna.............

Difficulty of keeping artificially impregnated eggs alive.....

Disadvantages labored $u$. der

XIV

$\mathrm{XIV}$

$X I I I$

XIV

$\mathrm{xVI}$

76

77

25

Lxrx

76

CIII

Disturbance of the fish. .

Drills and boring sponges

Duthiers H. Lacaze . 16,

Duvernoy, M.........

Earll, R. E......... IX

Ectoproctous forms...... 34

Ectosarc........... 39

Eggs heavier than water. I7 " of female oyster grow from ovicells......... 16

Entoproctous forms.... 34

Euplotes.........22, 38 
Excreta..............

Experiments conducted lastseason...........

Eyton, T. C..........

\section{F}

Faeces vent...........

Fatty material made up of nucleated cells........

"Fattening" process, physiology of the so-called

"Fattening" the oyster. .

Ferguson, T. B. . 3,44,53,

Fish and Fishery Laws... Public Local Laws. . Baltimore County...... Calvert " " $\quad . . \ldots$. Carroll $\quad$ " $\quad \ldots \ldots$. Cecil ‘ $\quad . . \ldots$.

Chester River.........

Frederick County .... Harford " " ...... Kent "6 .....

Patapsco River ...... Queen Anne County... Somerset "6 ...... Washington "... . Wicomico "6 $\ldots \ldots$. Worcester "6 ......

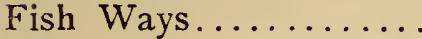

Fish Ways in Patuxent River.

Flemming ...... 5, 87,

Ford, Jno . . . . . . . 37,

Fraiche..........48,

France, Coast of.......

Frazier, Prof. P, Jr.....

Freia ampulla.........

Freia producta........

Fry at time of fixation .

\section{G}

Ganglia, Pair of

Gasperean (pom olo vernalis) (po molobus vernalis)

Gasteropods ....... 36,

Gelasimus ...........

Geodia..............

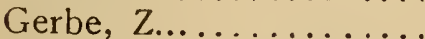

Glut-herring (pomolobus aestivalis) .......xLIX,

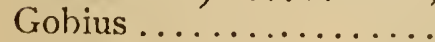

Goode, $G$. Brown.
PAGE.

$\mathrm{X}$ I I I

9 I

XLIX
$\mathrm{H}$

Hami'ton, His Excellency William $\mathrm{T}$

Hatching House.......

Havre de Grace Station. .

Herring-Cluptidae ..... XLv I I

Hertwig, O.... ..... 37

Histology of ovaries.... 5

Home, Sir Edward, I 2, I6, $\quad 76$

Hyatt, C. W.... . ... 33

House of Commons..... 33

Hydroids .......... 2 I

Hypoblast..... . . . 9 90

Increase of year I 880 more marked ........... VIII

Incubating apparatus. ...

Infusorian.........22,

Interdependent communities

Interference of other animal life ............

Investigations......... 50

VI I I

Jacobin, H.......... 79

Jardin des Plantes, Paris, 2 I

Johnston, Capt........ 33

$\mathrm{K}$

Kemmerer, Dr.........

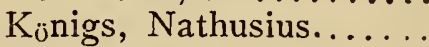

Kroger, H.............

Krogh, F.............

L

Lamellebranchiates......

Larval Barnacle. ovum,

Law prohibiting the catching of fish ignored....

Lease of Ponds ...... 3,

Leidy, Prof. ............

Les Sables D'Oleron.....

Letter of Supt. of Ex. Cos.

Lister................

Littorina irrorata............

"Lookout" Str ......(1x)

Localities in which herring are found ...........

Lyman, Theo.............

M

Mackerel at Crisfield. ...
42

76

77

35

$\mathrm{XIX}$

23

34

CXIV

I.XXI I

76

36

24

L

LI

XI 
Mackerel, Habits of....

Marennes .............

Maryland Academy of Sciences.............

Maryland Fish Com'n, Iv,

McCrady, Prof. Jno......

McDonald, Marshall, Iv,

McDonald's Fish Way....

McDonald's observations on herring.... ......

Meckelia...............

Menhaden .............

Méry...............

Mesosomal............

Methods of removing animal growth....

Microscopic fauna ....

Microciona proliferum, 32 ,

Minute monads …..32,

Möbius, I 6,26 30:33.40,49, $60,61,78$,

Mobjack Bay...........

Modiolaria ......32, 36,

Molgula ...........

Mollusks ..............

Mud and young fry....

Mud or gizzard shad ...

Nullus ...

Mya Arenaria, 5.35,40,83,

Mya, Importance and value of. . . . .......

Mya, Spawning season of. .......... 35 ,

Mytilus.......... 32,

\section{$\mathrm{N}$}

Nassalus ..............

Natural Banks.....

Navicula . . . . . " ostrearia . . 20,

Nereids . . . . . .

Nurseries . . . . . .

$\mathrm{O}$

Observations on alewives Obstructions on Patuxent Oligochaetous .... Osmosis, Laws of. . . Ostrea and Mya . . . . " conchaphila, Cal . “ cucullata, Viti Id's Pacific $U$... “ edulis . . I $2,6 \dot{6}$,
PAGE. $\mathrm{XI}$

CXIV 66

V I I I

L I I

49

$\mathrm{XLIX}$

33

84
" equestris Say, Florida.. . . .

“ peruviana, Peru. " virginiana. . 37, Oyster, The (Ostrea virginiana)... . . Oysters adhere in clusters Oysters, American . . . Oyster beds, fauna of . . Oyster " in Pokomoke and Tangier Sounds. Oyster crab..... 24 Oyster culturist, Enemy of 48 Oyster culture in Ches. Bay CxI I Oyster, development of . CxI Oysters, Effect of mud on 48 Oyster embryoes die on cold days.... .

Oyster, European....4, I 6,60 ,

Oyster, fauna of as interperdent communities.... Oyster, Food of.......

Oyster, Generative organs of the

Oyster, Growth of divided into three stages. ...

Oyster Laws............ Public Local Laws Dorchester County.... Potomac River........ Somerset County........ Wicomico " ....... Worcester " ........

Oyster, Nervous system of the.

CIX

6 I

40

Oyster, Number of which reached maturity...

CriI I

Oyster, "Poor" during spawning season...

Oyster, Sexes of are distinct

Oyster, Shell of the ... Oyster, Stomach of the .

Oystermen, Notions of as regards fattening the oyster.............

\section{$P$}

Patapsco River........

Patapsco River....... Pedesis or Brownian movement..........

\section{6}


Pedicellina Americana. Pennel Cholmondeley.... Peristome .............. Pericardial space........ I 1 , Pinnotheres ostreum. .... Poli............. I2, Polyps...............

Potomac River ( $). .$.

Premiums for ripe shad Probatocephalus.........

Proposed new methods of cdring for artificially impregnated eggs........

Propositions laid down by Möbius

Puysegur, M. of Sissable Pycnogonids . . . .

\section{$\mathrm{R}$}

Removal of barges to Watson's Island.

Renaud, J . . . . .

Reproductive organs during spawning season .

Respiration, or aeration of the blood.

Ryder, Prof. J. A . .

$\mathrm{S}$

Salensky . . . . 5, 78,

Salmo Fontinalis $:$. .

Salmo salar. . . . . " " eggs from the U. S. Com'r. . .

Sauerhoff, W. P...

Saunders, Jno. S . . .

$$
\text { "6 "Journal of }
$$

Say, $\mathrm{Mr}$

Schleswig Holstein •

Shad . . . .

Shad success on the Potomac

Shell, changes during growth of the...

Shell, mechanism of the

Shell, structure of the .

Slipper limpets . . .

Spat, numder of which fix themselves to a single slate.......

Spat, Rate of growth of . Sponges.....2 $\mathrm{I}$,

PAGE.

Stentor cocruleus . 39,

PAGE.

3
XLVII

St. Jerome's Creek (Cix) $3,26,30,35,38,47,53,60$, "Strike" of the fishermen

Structure of heart...

Systemic heart. . . .

\section{$\mathrm{T}$}

Table of catch of shad for I I years . . . . .

Table of amount of fish sold at Washington and Alexandria .

Table of temperature observations, Washington

Table of shad hatching operations, Washington .

Table of temperature ob-

servations at $H$. de $G$. xxxvi I I

XXIV

90

LXI I I

I I I I

LI I I

44

$\mathrm{XXIV}$

$\mathrm{XXV} I$

$\mathrm{xxV}$

24

26

XVI I

XVI I I

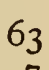

62

60

37

Table of hatching operations at H. de G . . .

Table of distribution of shad.

Table of distribution of Penobscot salmon

Table of distribution of $\dot{\mathrm{L}}$. L. salmon . . .

Table of salmon hatching operations . . . . .

Table of distribution of California salmon ...

Table of distribution of trout......

Table of distribution of carp

Table of catch of oysters 1879-1880 . . . .

Table of maximum and minimum temperature

Tolle A . . . . . .

Tunicates......

LXXIV

CXI I

Turrell, L . . . . .

$\mathrm{U}$

Urosalpinx

U. S. Coast and Geodetic

Susvey .

U. S. Fish Commission .

Unio ..... . 5,

V

Valves, difference in shape of . 
Valves, position of . .

Van Beneden. . . 24,

Van Leeuwenhock, A . .

Vanne. . . . . . .

Verrill, Prof . . 24,

Vibrones . . . . 25,

Von Jhering . . . . .

Von Ergo Rich. Ritter.

Vorticello . . . . .

Tर

White, Dr. C. A . . .

Whitman . . . . .

Why dredging injures beds

Willis......

Winslow, Francis, (Cvi),

4,62 .
78

Woonward's Manual of the Mollusca. . . . I2

Work of investigation, propagation, etc. . . I I I

Wrightson, J. WV 3,26 ,

$\mathrm{X}$

Xylotrya fimbriata. .

35

Y

Yield of the Potomac . .

VI

Z

Zoothamnium asbusculum 


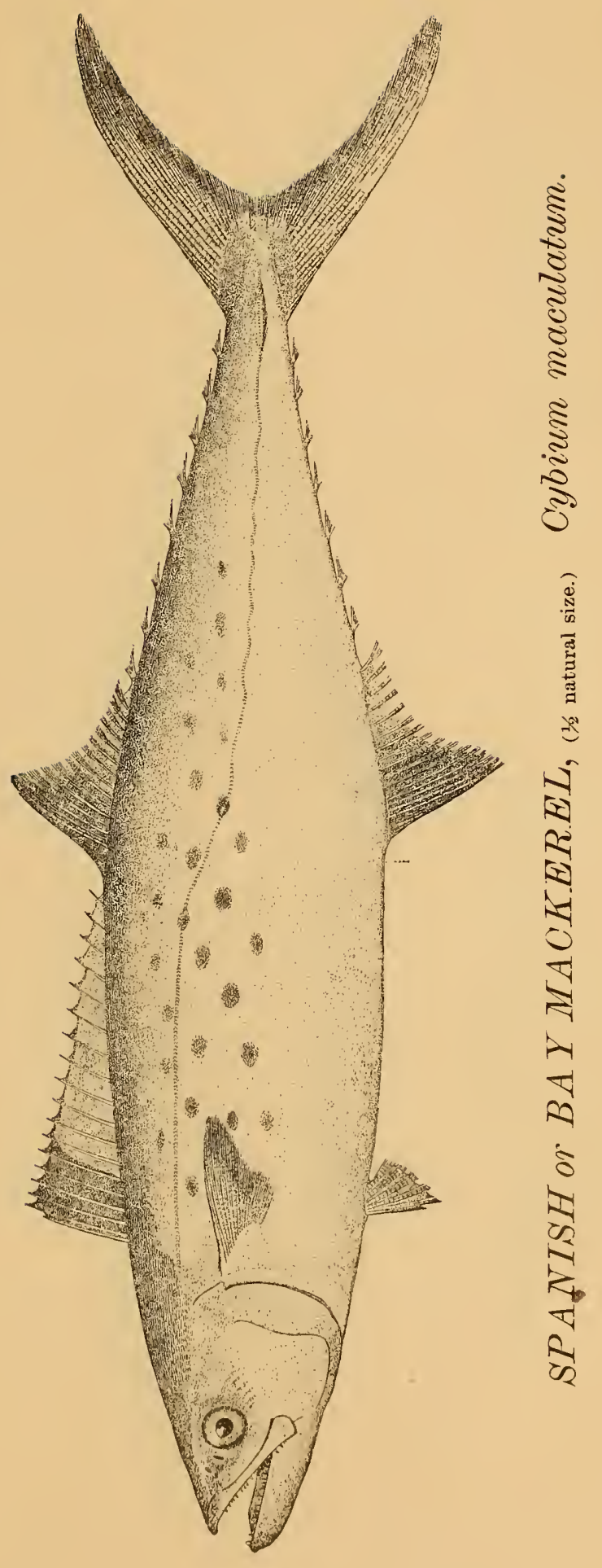





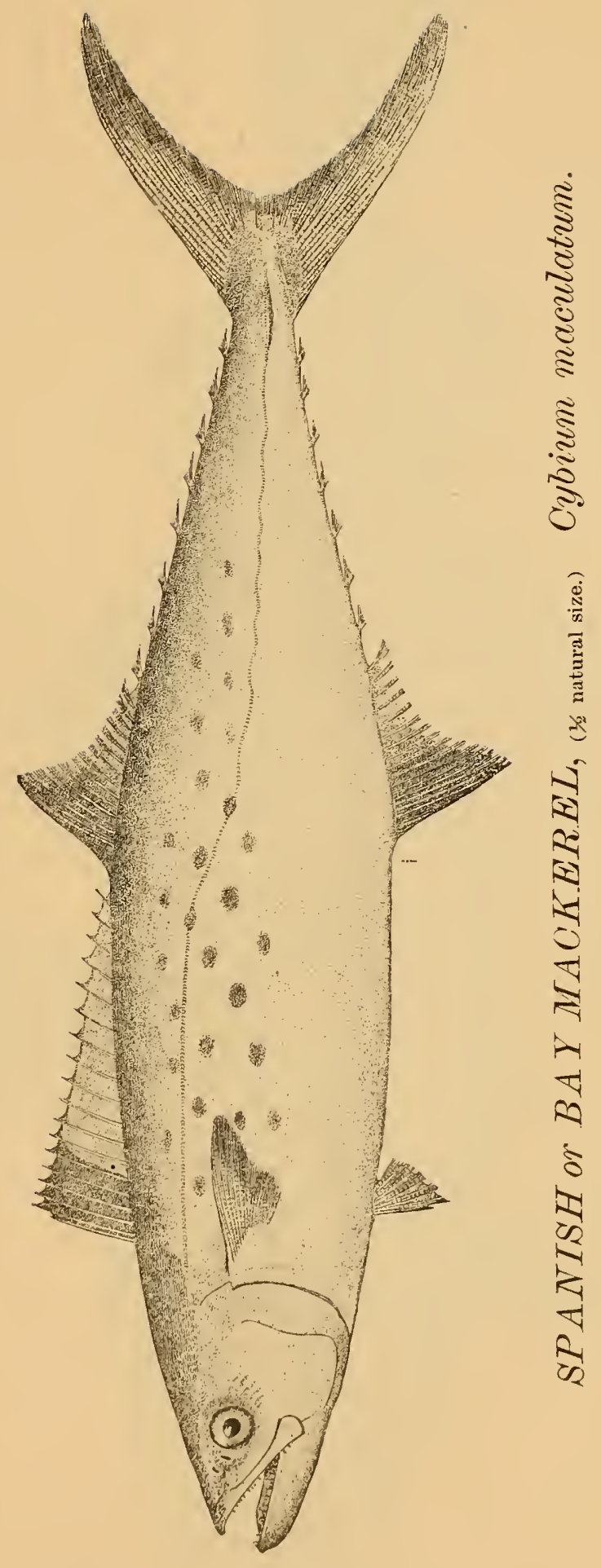





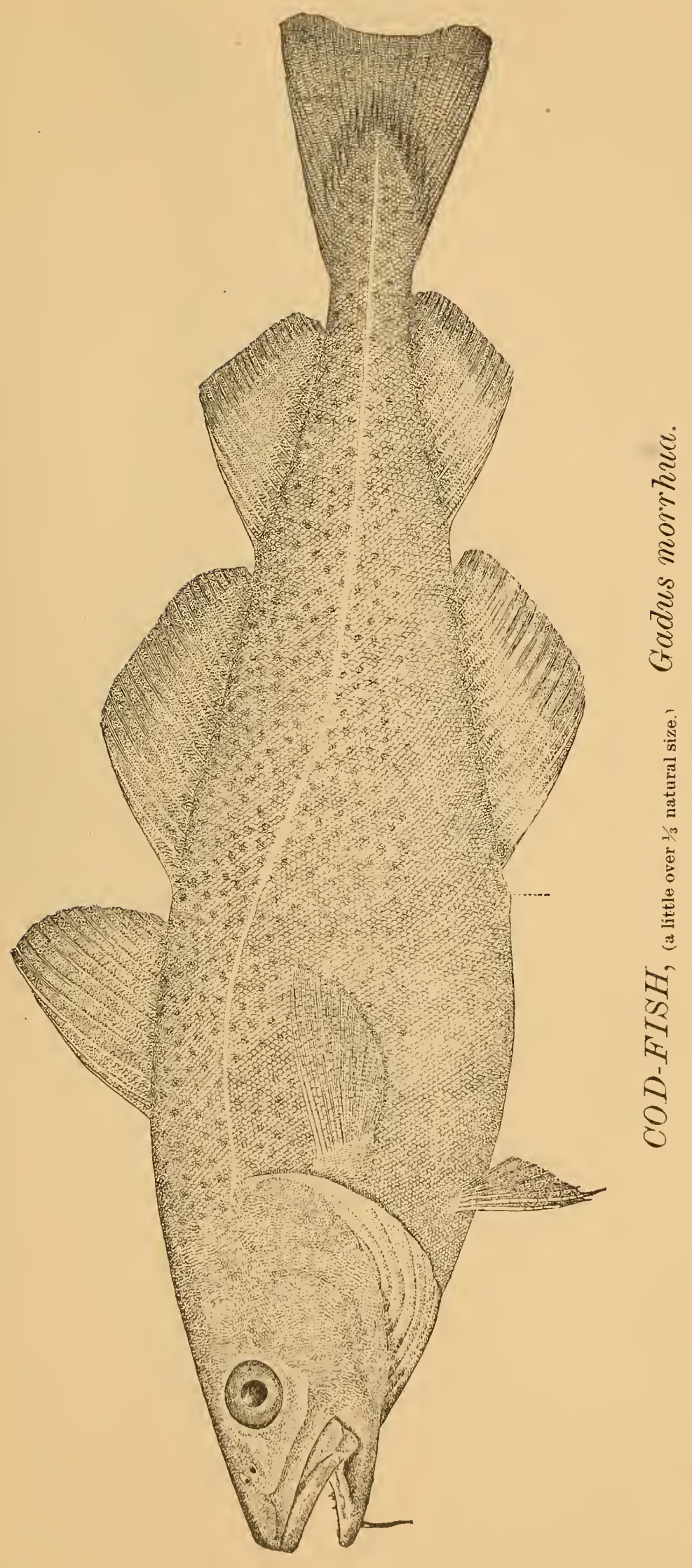





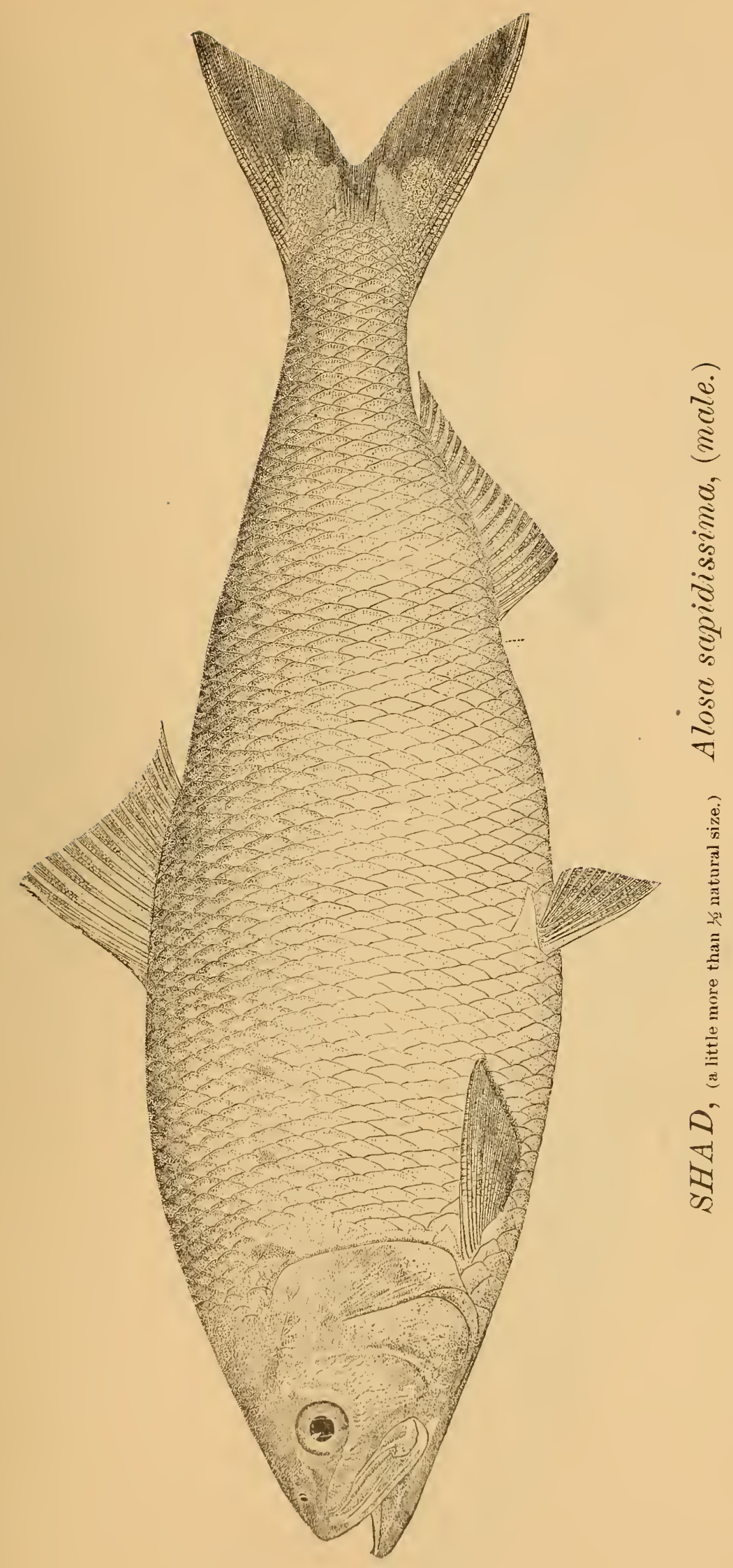





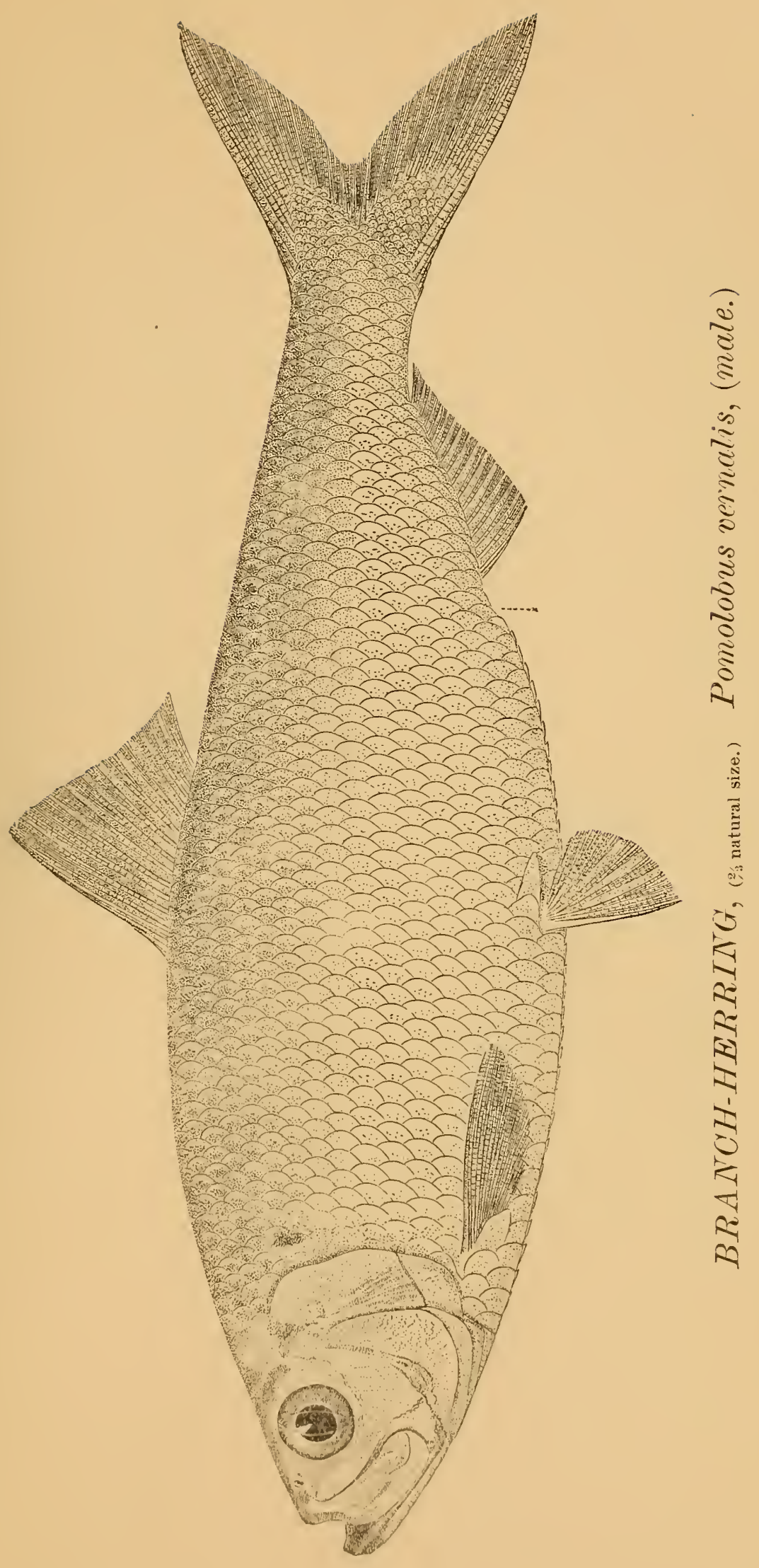





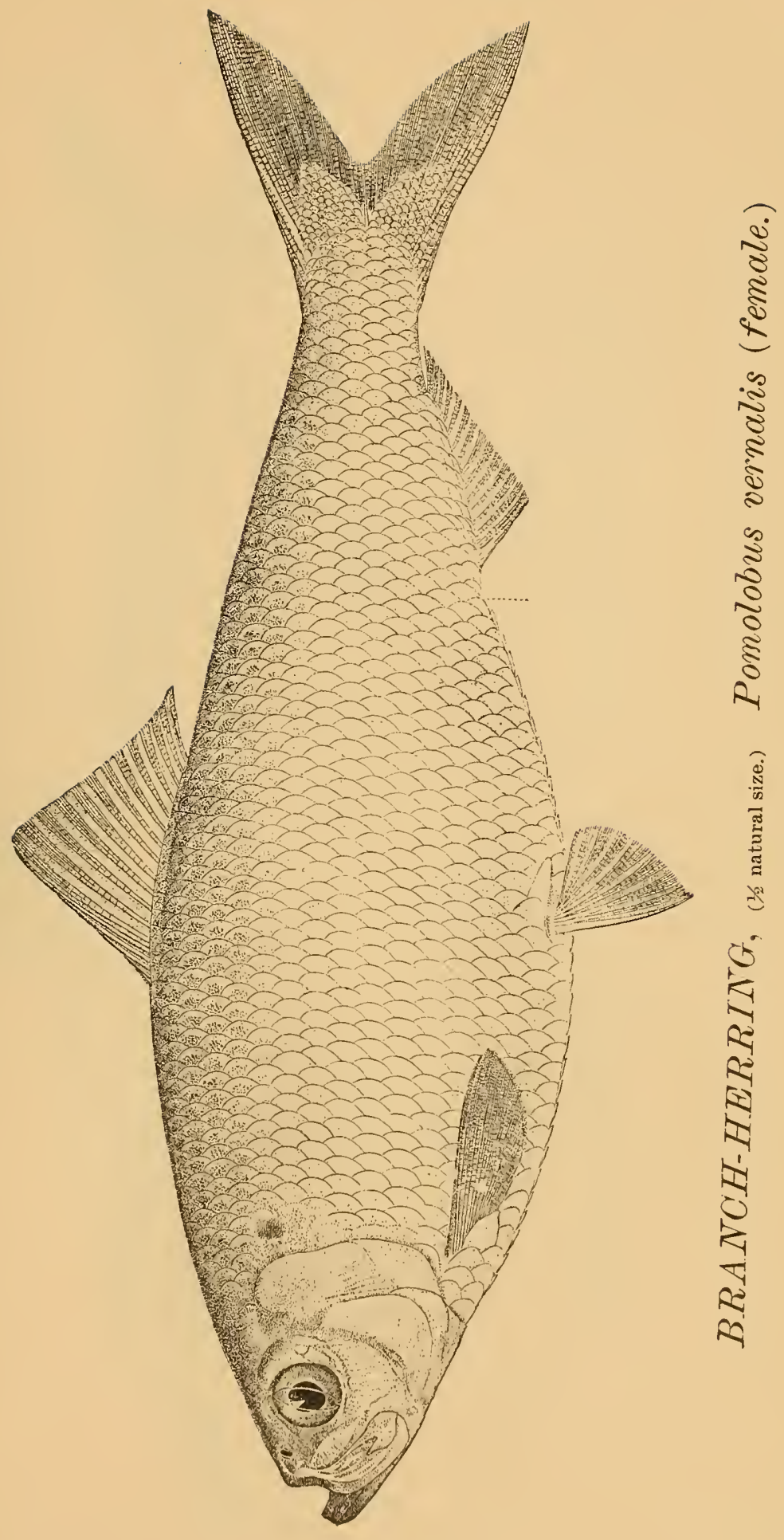





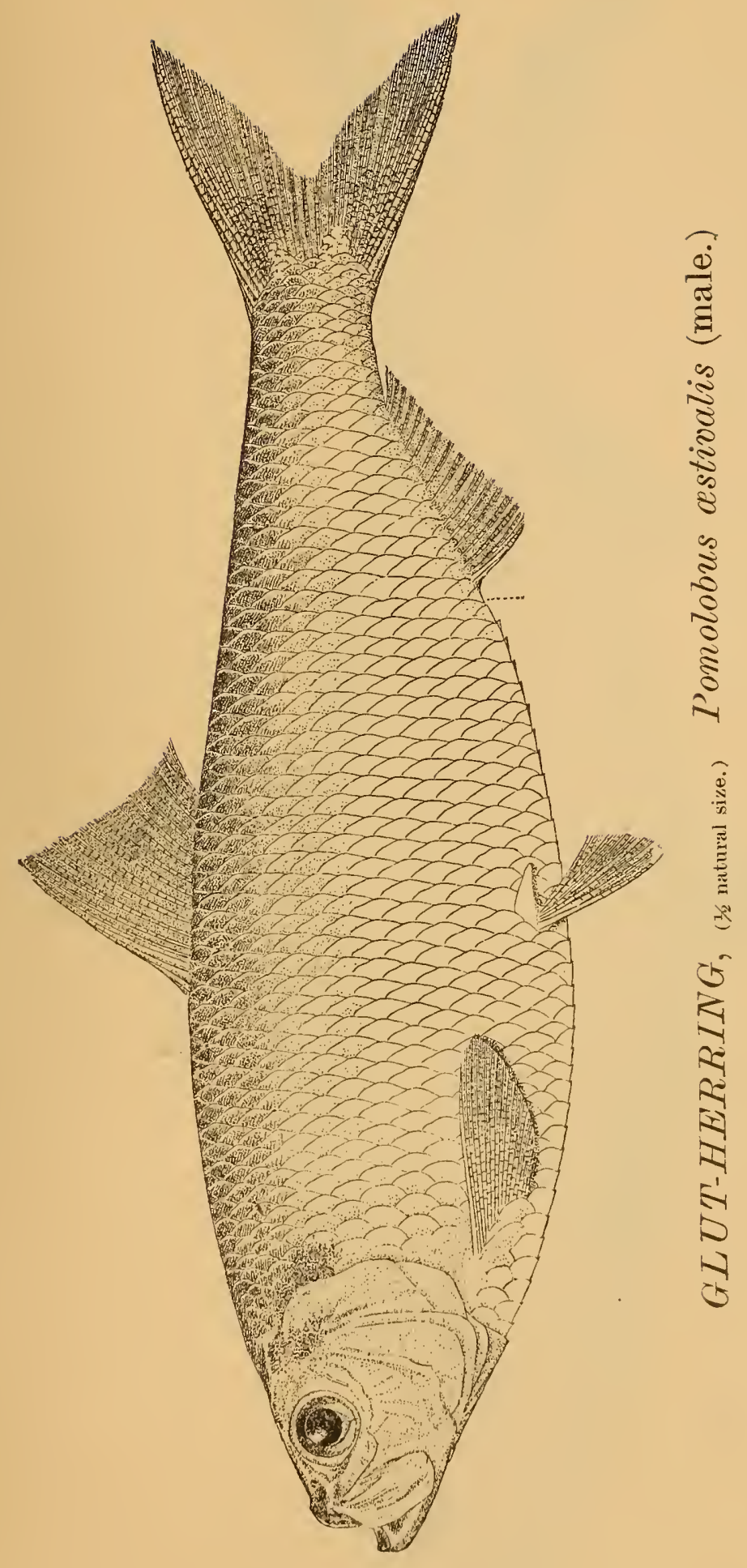





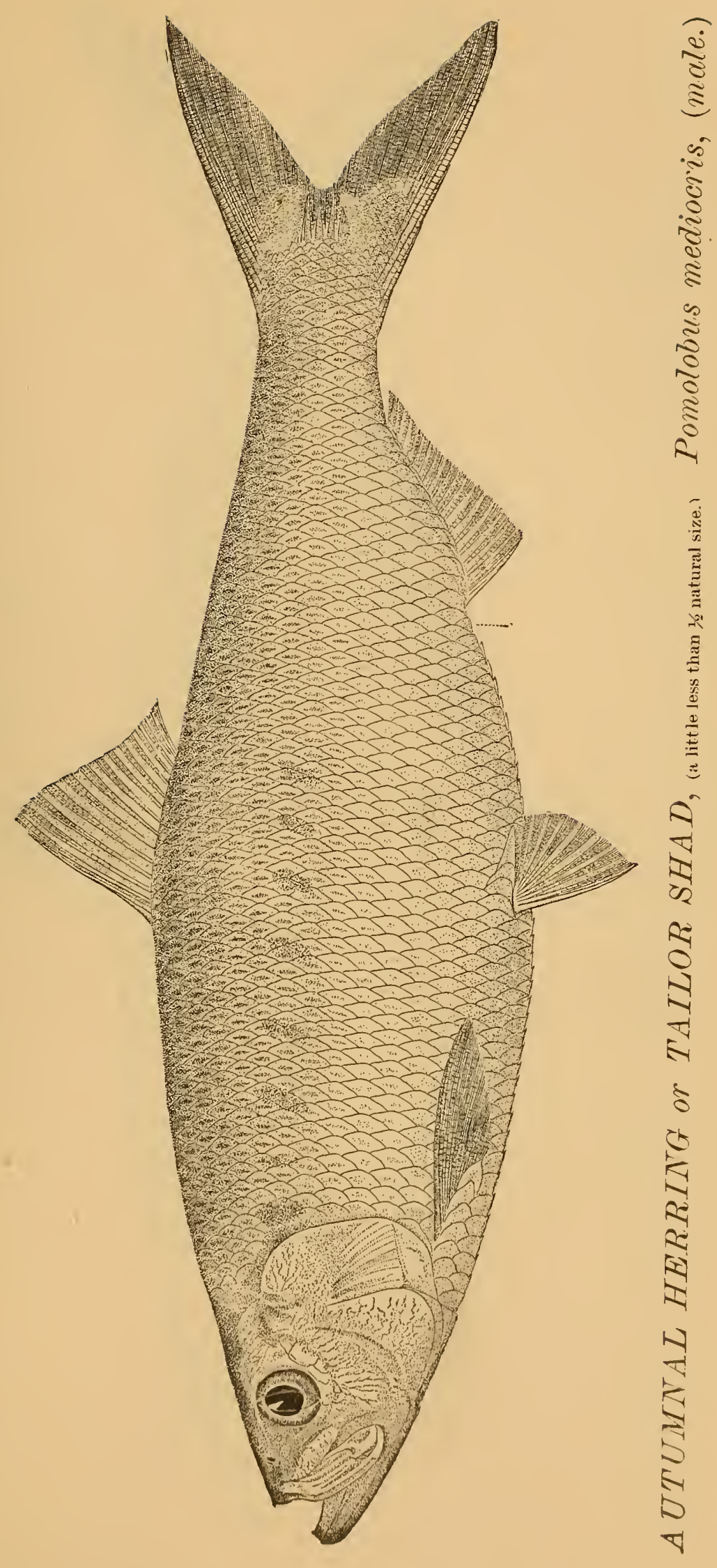





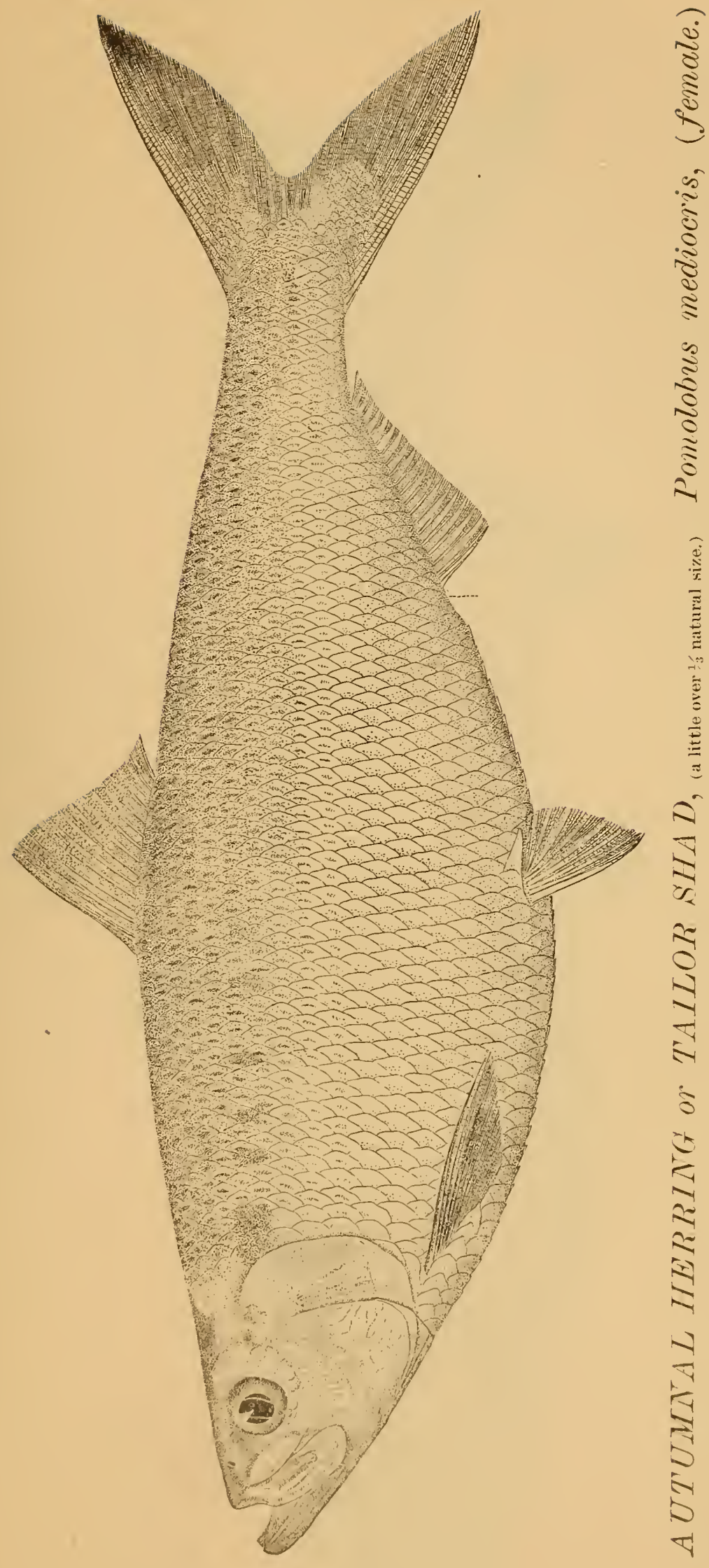





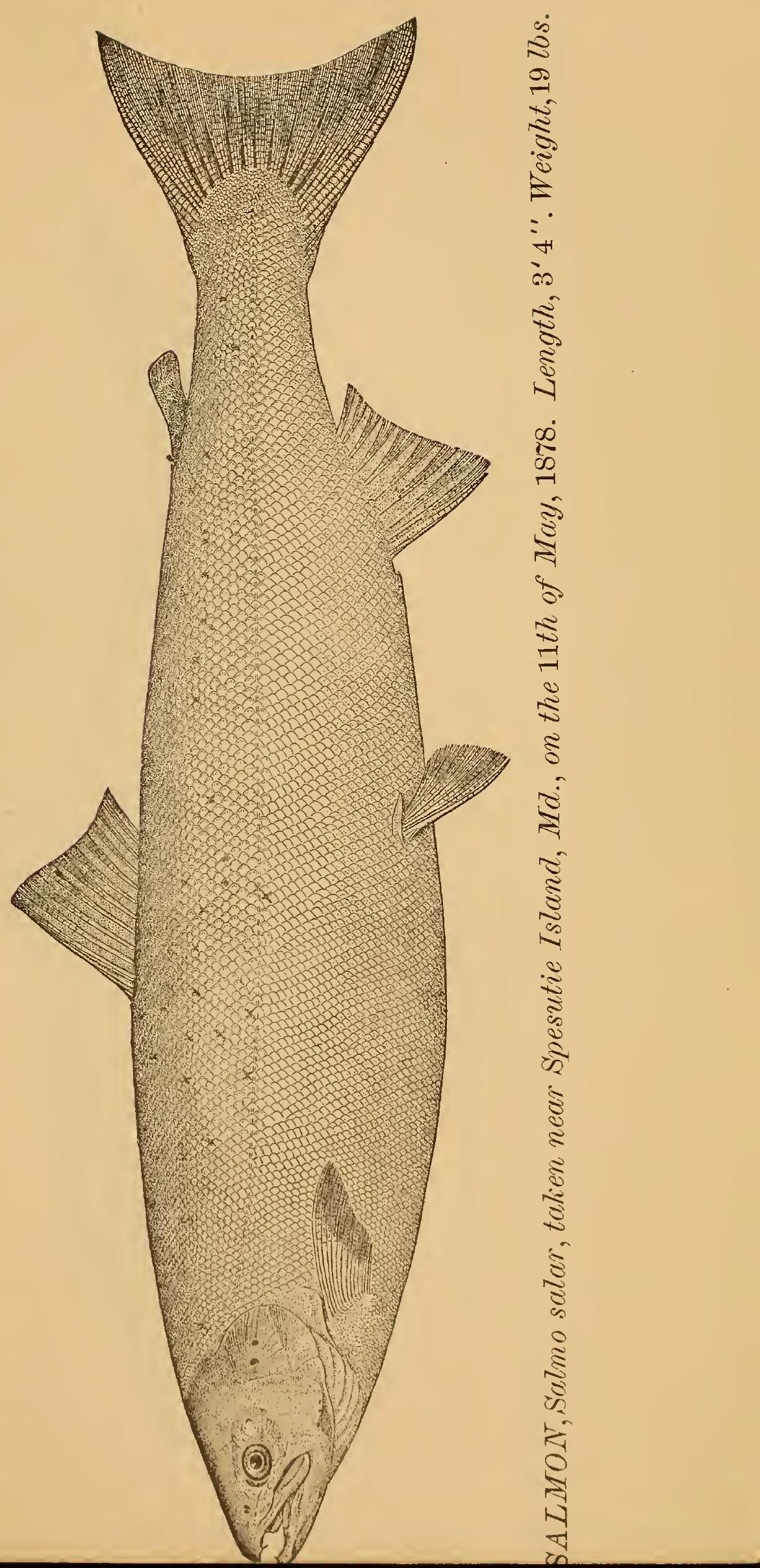





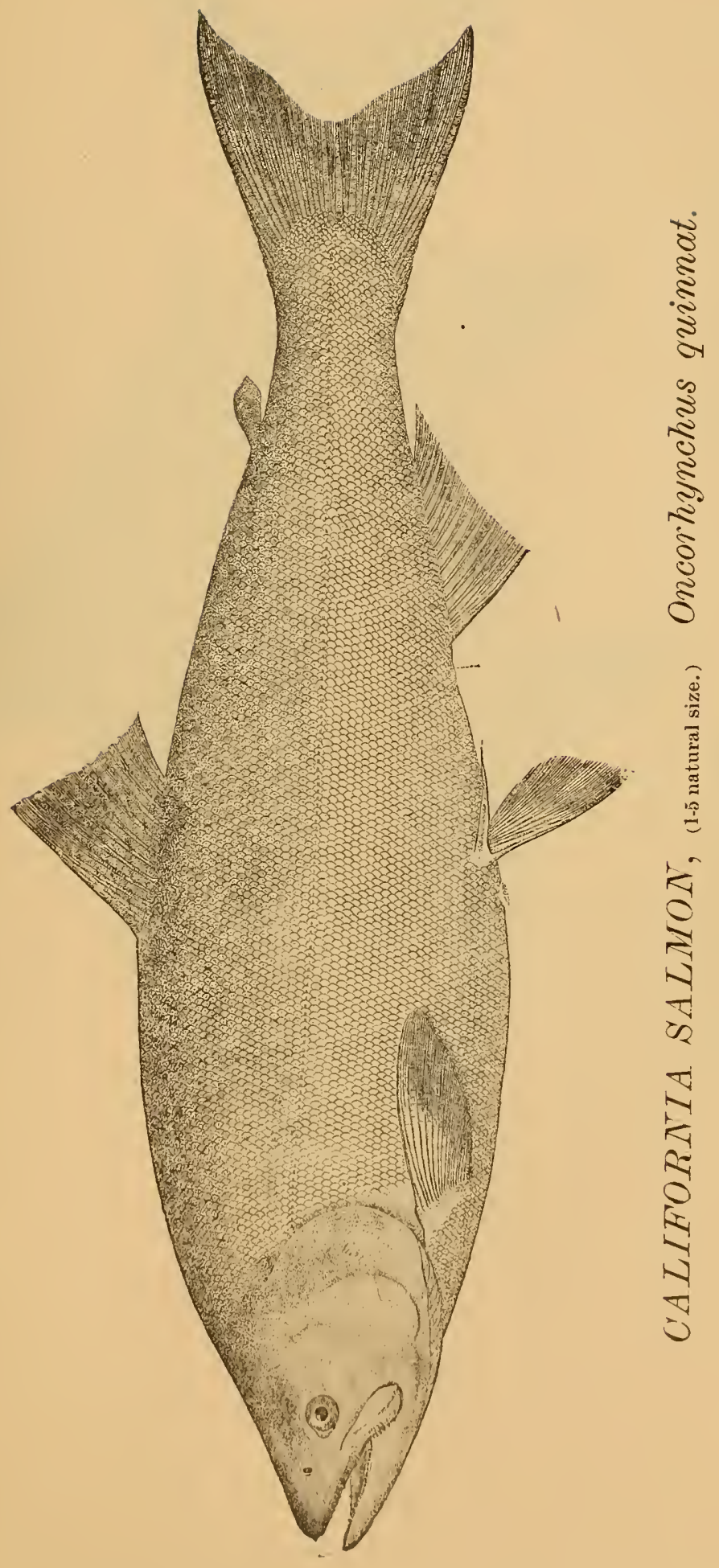





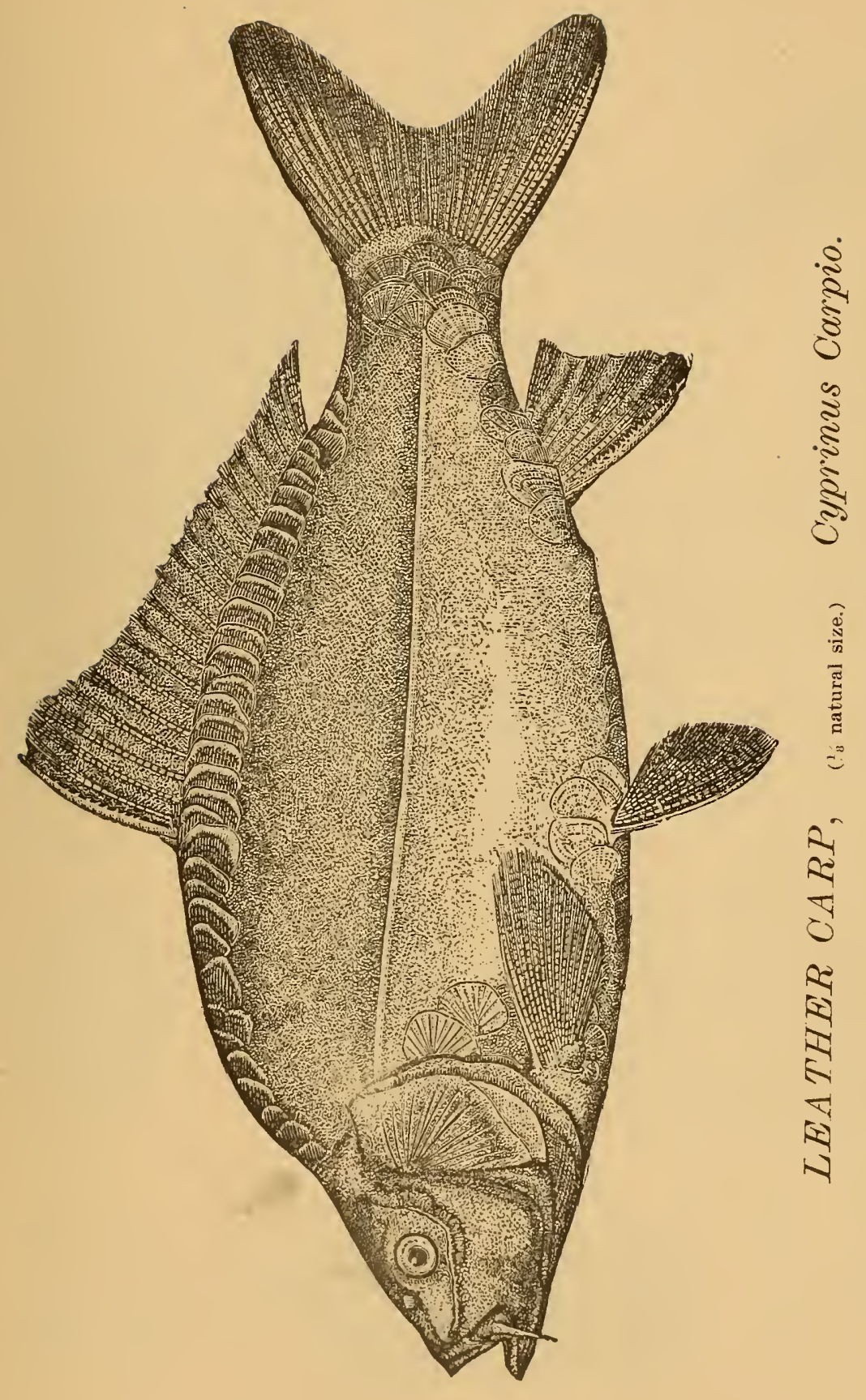




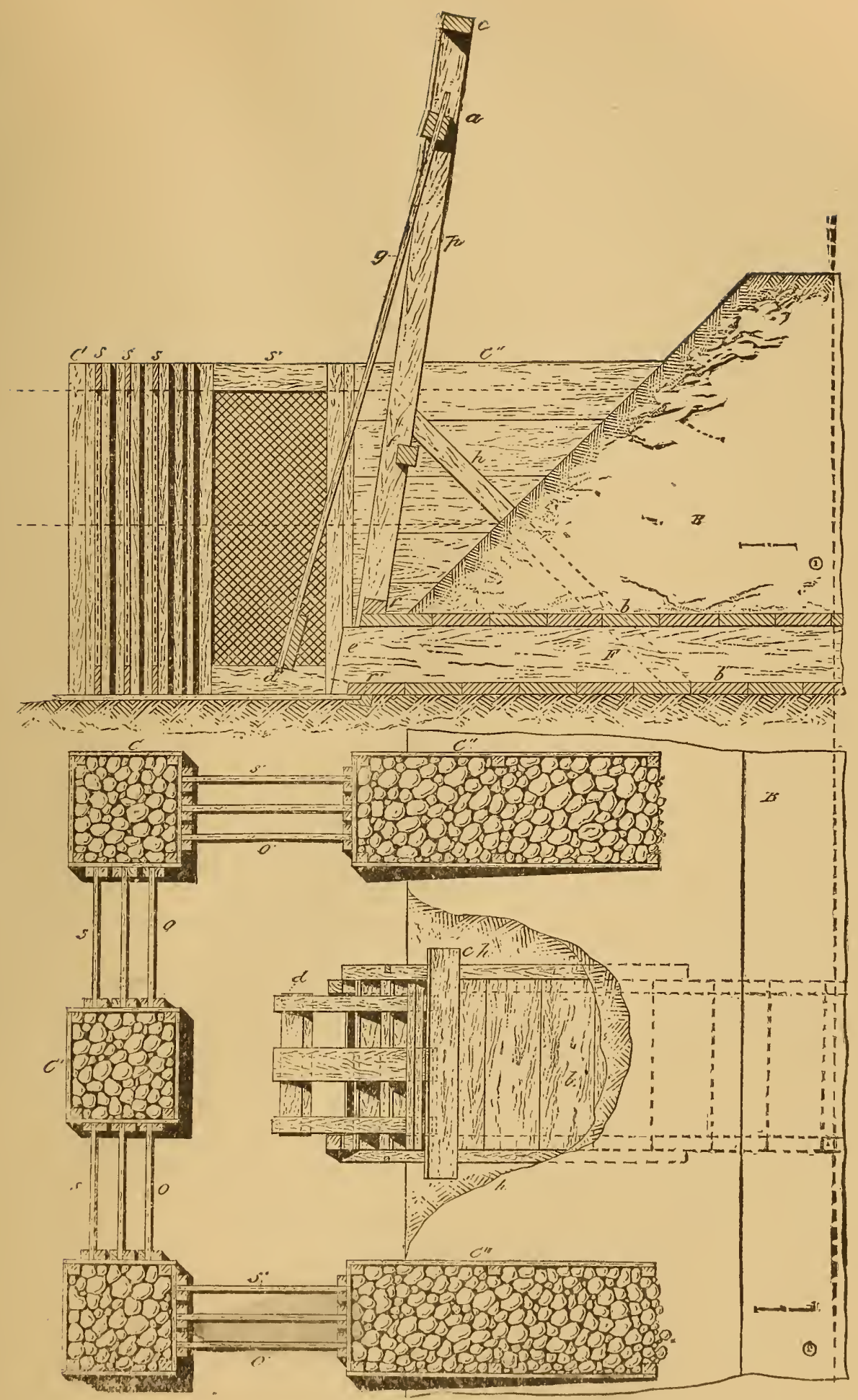




